\title{
Desempenho
}

construtivo de estruturas de cobertura com colmos de bambu Joan-Font Ballesté s

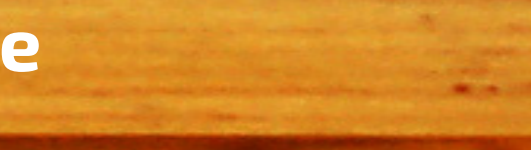




\section{Desempenho construtivo de estruturas de cobertura com colmos de bambu Joan Font Ballesté}

Dissertação de Mestrado

Faculdade de Arquitetura e Urbanismo da Universidade de São Paulo - FAU USP

Programa de Pós-Graduação em Arquitetura e Urbanismo

Área de Concentração: Tecnologia da Arquitetura.

Linha de Pesquisa: Tecnologia da Construção.

Orientadora: Erica Yukiko

Yoshioka.
Projeto realizado com o apoio do CNPq - Conselho Nacional de Desenvolvimento Científico e Tecnológico, através de bolsa de mestrado, desde abril de 2015.

EXEMPLAR REVISADO E ALTERADO EM RELAÇÃO À VERSÃO ORIGINAL, SOB RESPONSABILIDADE DO AUTOR E ANUÊNCIA DO ORIENTADOR.

O original se encontra disponível na sede do programa. 


\section{Autorizo a reprodução e}

divulgação total ou parcial deste

trabalho, por qualquer meio

convencional ou eletrônico, para

fins de estudo e pesquisa, desde

que citada a fonte.

\section{Email do autor}

joan.com.jo@gmail.com

\section{Catalogação na Publicação}

Serviço Técnico de Biblioteca

Faculdade de Arquitetura e Urbanismo da Universidade de São Paulo

\begin{tabular}{|c|c|}
\hline \multirow[t]{3}{*}{ B191d } & $\begin{array}{l}\text { Balleste, Joan Font } \\
\text { Desempenho construtivo de estruturas de cobertura } \\
\text { com colmos de Bambu / Joan Font Balleste ; } \\
\text { orientadora Erica Yukiko Yoshioka. - São Paulo, } \\
2017 \text {. } \\
222 \text { p. }\end{array}$ \\
\hline & $\begin{array}{l}\text { Dissertação (Mestrado) - Faculdade de Arquitetura } \\
\text { e Urbanismo da Universidade de São Paulo. Área de } \\
\text { concentração: Tecnologia da Arquitetura }\end{array}$ \\
\hline & $\begin{array}{l}\text { 1. Bambu. 2. Sistemas Construtivos. } 3 . \\
\text { Estruturas. 4. Desempenho de Materiais de Construção. } \\
\text { 5. Sustentabilidade. I. Yoshioka, Erica Yukiko, } \\
\text { orient. II. Título. }\end{array}$ \\
\hline
\end{tabular}




\section{Desempenho construtivo de estruturas de cobertura com colmos de bambu Joan Font Ballesté}

Aprovado em: 22/05/2017

Banca Examinadora:

Prof. Dr. Antonio Ludovico Beraldo FEAGRI UNICAMP

Profa. Dra. Célia Regina Moretti Meirelles

FAU UPM

Profa. Dra. Érica Yukiko Yoshioka FAU USP
Dissertação apresentada à Faculdade de Arquitetura e Urbanismo da Universidade de São Paulo para obtenção do título de Mestre em Arquitetura e Urbanismo. 

O caráter espontâneo do bambu é a retidão. Sua virtude natural se manifesta em sua forma de crescimento sempre reto e para cima, dobrando-se docilmente para iludir os obstáculos. Sua ascensão não é violenta, mas modesta e dócil, sem pressa e sem pausa. Assim, seu caráter abnegado e reto é modelo para o homem sábio.

Antônio Luiz de Barros Salgado 

Primeiramente gostaria de agradecer à Faculdade de Arquitetura e Urbanismo da Universidade de São Paulo, por me dar a oportunidade de fazer parte do programa de Pós-graduação.

Ao CNPq, pela bolsa concedida que possibilitou a realização deste trabalho.

À Profa. Dr. Erica Yoshioka Yukiko, pela competência, dedicação e paciência ao me orientar durante todo o processo de mestrado e pelos ensinamentos que a convivência juntos me trouxe.

Ao Prof. Dr. Reginaldo Luiz Nunes Ronconi, pela oportunidade de fazer parte do programa PAE como estagiário nas disciplinas por ele ministradas e no Laboratório de Culturas Construtivas (LCC), que foram experiências imensamente enriquecedoras do ponto de vista acadêmico e pessoal.

Ao Prof. Dr. Paulo Júlio Valentino Bruna, pelo incentivo para que entrasse no programa de Pós-graduação da FAU-USP e à constante formação acadêmica.

Âs minhas companheiras bambuzeiras, Mirella Ruggiero, Juliana Becker, Paula Noia e Márcia Sato, pela troca de conhecimentos e o suporte anímico.

Aos membros do Laboratório de Culturas Construtivas, Chico Barros, Danilo Costa e Daniel Jhun.

À Leiko Motomura e ao Natan Lavental, pelas entrevistas concedidas.

Ao Moreno Zaidan, pela ajuda inestimável e constante na parte mais burocrática do curso de mestrado.

Aos meus amigos que interviram de forma direta na produção deste trabalho: Luciana Mattar, Lara Ferreira, Argos Silva, Ricardo Bozza, Gabriel Kolisch, Ana Dalla Rosa e Felipe Antonoff.

Aos meus amigos que interviram de forma indireta na produção deste trabalho: Paulo, Luis, Daniela, Felipe, Fred, Fernando, Albers, Hermes, Renato, Camila, Sandro, Silvio, Leonardo, Laercio e todos que tenham convivido comigo durante estes últimos três anos.

Finalmente, quero agradecer aos meus pais, Josep e Montserrat, por me encorajar a fazer o mestrado mesmo longe deles. 
The focus of this research is the study of the performance of bamboo in coverage structures. The architecture of the 21 st century needs new production models and new materials to enable the sustainable development of the planet. Bamboo is a renewable material, with low production costs, positive ecological footprint and excellent physical-mechanical properties; but there is a rather general lack of knowledge about its use in civil construction. This gap is even greater when one tries to understand its structural behaviour over time. Among the various requirements to evaluate the performance of the material, when it is the structural element in a construction, two that stand out are essential: stability and durability. In this work, the understanding of the physical and mechanical behaviour of the material in the microscopic and macroscopic composition is sought first to delimit its structural safety, and secondly, examining the processes that, since the plants's growth until its usage in work, determine the useful life of the material. It is also analyzed the constructive practices and project actions that condition transversally these two performance requirements, along with a survey of case studies that aim to create new criteria of structure design and building solutions. This research seeks to export the strengths and weaknesses of the current construction with bamboo, so the first may be potentialized and the latter corrected. 
O foco desta pesquisa é o estudo do desempenho de colmos de bambu em estruturas de cobertura. A arquitetura do século XXI precisa de novos modelos de produção e novos materiais para possibilitar o desenvolvimento sustentável do planeta. O bambu é um material renovável, com custos de produção baixo, pegada ecológica positiva e de qualidade física excelente; mas existe um desconhecimento bastante generalizado sobre o seu uso na construção civil. Esta lacuna é ainda maior quando se procura entender seu comportamento estrutural ao longo do tempo. Entre os vários requisitos para avaliar o desempenho do material, quando é o elemento portante de uma construção, destacam-se dois que são essenciais: a estabilidade e a durabilidade. Neste trabalho procura-se, em primeiro lugar, compreender o comportamento físico-mecânico do material na composição microscópica e macroscópica para delimitar sua segurança estrutural, e em segundo lugar, examinar aqueles processos que, desde o crescimento da planta até à sua utilização em obra, determinam a vida útil do material. São também analisadas as práticas construtivas e ações de projeto que condicionam transversalmente estas duas exigências de desempenho, junto com um levantamento de estudos de caso que visa criar novos critérios de design de estruturas e soluções construtivas. Esta pesquisa procura expor os pontos fortes e fracos da atual construção com bambu, para que os primeiros sejam potencializados e os segundos sejam corrigidos.

PALAVRAS-CHAVE: Bambu. Sistemas Construtivos. Estruturas.

Desempenho de Materiais de Construção. Sustentabilidade. 


\section{Sumário}

\section{Introdução}

1

\section{Dimensão sociocultural e botânica do bambu}

$1.1 \mathrm{~A}$ arquitetura sustentável

1.20 bambu como material alternativo

1.30 bambu na construção civil

1.4 Aspectos botânicos do Bambu

1.4.1 Taxonomia

1.4.1.1 Sistemas de classificação

1.4.1.2 Distribuição geográfica

1.4.2 Morfologia

1.4.2.10 colmo

1.4.2.2 A base do colmo

1.4.2.3 Colo do rizoma

1.4.2.4 Rizoma

1.4.2.5 Ramificação

1.4.2.6 Folhas e bainhas

1.4.3 Crescimento do colmo

2

\section{Caracterização}

do colmo de bambu

2.1 Microestrutura do bambu

2.1.1 0 tecido celular do colmo

2.1.1.1 Parênquima

2.1.1.2 Vasos condutores

2.1.1.3 Fibras

2.1.1.4 Feixes vasculares

2.1.2 Estrutura do internó

2.1.2.1 Camada externa
2.1.2.2 Camada interna

12
21.2.3 Parede do colmo

20

Estrutura do nó

2.2 Macroestrutura do bambu

2.2.1 Caraterização geométrica

2.2.1.1 Comprimento internodal

2.2.1.2 Diâmetro externo do bambu

2.2.1.3 Espessura da parede

2.2.1.4 Altura do colmo

2.2.2 Propriedades químicas

2.2.3 Propriedades físicas

2.2.3.1 Massa específica

2.2.3.2 Umidade

2.2.3.3. Estabilidade dimensional

2.2.4 Propriedades mecânicas

2.2.4.1 Tração axial

2.2.4.2 Compressão axial

2.2.4.3 Flexão estática

2.2.4.4 Cisalhamento axial

2.2.4.5 Cisalhamento transversal

2.2.4.6 Tração perpendicular

2.2.4.7 Compressão perpendicular 2.2.4.8 Torção

$41 \quad 2.2 .5$ Material compósito

41 funcionalmente graduado

$42 \quad 2.3$ Fatores de influência na anatomia

42 do bambu

$43 \quad$ 2.3.1 Clima

$44 \quad 2.3 .2$ Solo

$44 \quad$ 2.3.3 Altitude

$44 \quad$ 2.3.4 Topografia

$44 \quad 2.3 .5$ Idade
45
Processamento e manejo do bambu para construção civil

3.1 Cultivo do bambu

3.11 Preparação do terreno para 0

plantio

3.1.2 Tratamento durante o plantio $\quad 71$

3.1.3 Adubação

3.1.4 Rendimento do plantio $\quad 72$

3.1.5 Propagação do bambu $\quad 72$

3.1.6 Maturação dos colmos $\quad 73$

3.2 Colheita $\quad 74$

3.2.1 Corte de bambu $\quad 75$

3.3 Secagem 76

3.4 Preservação 77

3.4.1 Ataques à planta $\quad 78$

3.4.1.1 Ataques a bambus vivos $\quad 78$

3.4.1.2 Ataques a bambus abatidos 78

3.4.1.2.1 Fungos apodrecedores $\quad 78$

3.4.1.2.2 Caruncho 80

3.4.1.2.3 Cupim 80

3.4.2 Tratamento preservativos do 80

bambu

3.4.2.1 Tratamentos físicos $\quad 82$

3.4.2.1.1 Cura na mata $\quad 82$

3.4.2.1.2 Cura por imersão $\quad 82$

3.4.2.1.3 Cura por defumação $\quad 82$

3.4.2.1.4 Cura por calor $\quad 82$

3.4.2.2 Tratamentos químicos $\quad 84$

3.4.2.2.1 Aproveitamento da $\quad 84$

transpiração 
3.4.2.2.2 Boucherie

3.4.2.2.3 Boucherie modificado

3.4.2.2.4 Tratamento por imersão

3.4.2.2.5 Banho quente-frio

3.4.2.2.6 Aplicação externa

3.4.2.2.7 Por injeção nos colmos

3.4.2.2.8 Autoclave

3.4.2.2.9 Produtos utilizados

\section{4 \\ Construção estrutural com bambu}

4.1 Sistemas estruturais

4.2 Elementos construtivos das estruturas

4.2.1 Colmos
4.2.1.1 Qualidade dos colmos
4.2.1.2 Princípios de utilização
4.2.1.3 Cortes
4.2.2 Conexões
4.2.2.1 Condicionantes para o
design de conexões
4.2.2.2 Classificação de conexões
4.2.2.3 Princípios construtivos das
conexões
4.2.2.4 Cálculo de estruturas
4.3 Princípios construtivos de
estruturas de bambu
4.4 Desempenho de estruturas de
bambu

4.4.1 Patologias

4.4.1.1 Durabilidade

4.4.1.2 Estabilidade

4.4.1.2.1 Fendilhamento

4.4.1.2.2 Esmagamento

4.4.2 Resistência ao fogo

4.4.3 Resistência a movimentos

sísmicos

4.5 Normas

4.5.1 Normas internacionais

4.5.1.1 Norma técnica E100 Bambú

5

\section{Estudos de caso}

94

5.1 Avaliação das patologias em

94 estruturas de bambu

97

5.1.1 Escolha dos estudos de caso

5.1.2 Metodologia

5.1.3 Exigências do usuário

5.2 Estudo de caso: Amana Key Sala de 128

Diálogos de Verão

5.2.10 projeto de arquitetura $\quad 129$

5.2.2 A cobertura com estrutura de 135

bambu

5.2.3 Análise das conexões

138

5.2.4 Levantamento patológico $\quad 140$

5.2.5 Considerações finais $\quad 158$

5.3 Estudo de caso: Centro Cultural 160

110 Max Feffer

5.3.1 0 projeto de arquitetura
5.3.2 A cobertura com estrutura de

bambu

5.3.3 Análise das conexões

5.3.4 Levantamento patológico

5.3.5 Considerações finais

170

174

208

114

1146

\section{Conclusões}

\section{7}

Referências bibliográficas

\section{8}

120 Anexos (DVD - digital)

8.1 Entrevista a Leiko Hama Motomura

1208.2 Entrevista a Natan Jacobsohn

Lavental

8.3 Modelo de cálculo estrutural para STRAP do projeto Amana Key

8.4 Modelo de cálculo estrutural para STRAP do projeto Centro Cultural Max Feffer

62 


\section{Apresentação do problema e justificativa}

Invariavelmente, toda ação realizada por um arquiteto através de um projeto implica uma reação materializada na obra. Para que esta ação seja qualificada positivamente, é necessário que a reação seja condizente com o desejado, conforme prevista em projeto, satisfazendo plenamente os parâmetros de habitabilidade e as necessidades do usuário que vivencia tal espaço arquitetônico.

As ações dos arquitetos envolvem desdobramentos extremamente mais complexos do que a mera relação destes com o usuário final, pois, numa escala maior, o arquiteto é parte integrante da cadeia produtiva de um dos mais importantes setores econômicos na sociedade: a construção civil.

$\mathrm{Na}$ construção de uma edificação, além do binômio formado por arquiteto e usuário, existe uma rede de agentes interligados, formada por produtores de materiais, construtores, engenheiros e operários que, em maior ou menor proporção, condicionam-se uns aos outros e influenciam a tomada de decisões durante a concepção do projeto e a execução da obra, podendo influenciar até mesmo a forma de utilização do edifício.

Mesmo com esta complexa trama, na qual distribui-se responsabilidades e sobre a qual recaem as exigências, o agente primordial é o arquiteto, que, através de sua visão panorâmica sobre as demais disciplinas, concentra em si a maioria das decisões que definem o partido de uma construção, desde a seleção de materiais e a associação destes por meio de princípios construtivos de seu domínio, até questões estéticas que caracterizam espacialmente $\mathrm{o}$ ambiente construído.

Quando o arquiteto age, por exemplo ao selecionar um material que exercerá uma função determinada numa construção, deve dominar suas poten- 
cialidades, conhecendo seus pontos fortes e fracos, para que, uma vez instalado em obra, a reação obtida atenda satisfatoriamente a solicitação pressuposta.

Recentemente, o bambu vem ganhando notoriedade no meio arquitetônico por ser considerado um material que traz consigo contrapartidas ambientais positivas, ampliando os índices de sustentabilidade em edificações. Apesar de, no Brasil, ser considerado um material relativamente novo pelos agentes da construção civil e pouco visto nos centros urbanos, é utilizado há muitos séculos por comunidades rurais e indígenas.

O bambu é um material acessível e está presente na maior parte do planeta há milhares de anos; contudo, a escassa literatura e a falta de pesquisa acerca de suas aplicações, se comparado aos materiais convencionais, faz com que seu comportamento seja imprevisível quando utilizado, restringindo suas aplicações.
Sua composição faz com que seja considerado um material de caraterísticas mecânicas extraordinárias, extremamente apto a ser utilizado em construção. Sua capacidade de resistir a esforços de tração e compressão de grande intensidade, o torna um potencial concorrente de materiais convencionais utilizados em estruturas.

Apesar destas vantagens, seus colmos divididos em nós e internós, derivados do processo de crescimento, criam dificuldades para que seja processado, restringindo sua utilização direta na obra.

Diferente dos materiais tradicionalmente utilizados como elementos estruturais, sua composição biológica não permite modificações como aço, concreto ou madeira, que podem ter formas abstratas, adequando-se como elementos de sistemas estruturais de geometrias uniformes.

Vantagens e desvantagens à parte, as possibilidades que o bambu roliço pode oferecer ainda não foram exploradas em sua exaustão. Processos para produzir vigas e pilares de bambu com dimensões customizáveis não estão suficientemente evoluídos para um uso economicamente viável.

Mesmo com limitações, muitos exemplos de arquitetura com bambu roliço utilizado de modo estrutural podem ser encontrados ao redor do globo, em alguns casos com sofisticação técnica brilhante.

Dentre as tipologias construtivas em que é mais utilizado destacam-se as coberturas, quem sabe o primeiro conjunto arquitetônico idealizado pelo homem, concebido como abrigo para se proteger de adversidades climáticas.

$O$ fato de não haver cargas acidentais nas coberturas, como ocorre nos demais pavimentos, geradas pela circulação de usuários e presença de equipamentos e mobiliários, faz com que os requisitos de estabilidade dinâmicas sejam menos rígidos, favorecendo sua utilização. 
Assim, analisar as idiossincrasias do bambu, utilizado em seu estado natural em estruturas de cobertura, parece ser um ponto de partida lógico para qualificar, tanto o material quanto as ações dos arquitetos que já o utilizaram, e contribuir na produção de conhecimento sobre o assunto, para que os princípios envolvidos em sua utilização sejam mais criteriosos em projetos arquitetônicos futuros.

A análise do bambu e de suas aplicações estruturais em estado natural na construção civil foi realizada a partir de cinco abordagens diferentes, cada uma dispondo de um capítulo específico, tendo sido as quatro primeiras embasadas na revisão bibliográfica realizada e a quinta em estudo de casos.

Cabe destacar que a literatura sobre uso do bambu como material de construção não é muito extensa ao comparar-se com outros materiais lhos sobre o assunto remetem-se constantemente a um grupo reduzido de autores, que, por esta razão, inevitavelmente foram estudados neste trabalho.

$\mathrm{Na}$ primeira abordagem, o bambu é apresentado como espécie vegetal, incluindo suas características botânicas, e inscrito no contexto socioeconômico global. Para este capítulo, um dos livros usados com maior recorrência foi Bambu de corpo e alma, escrito por Marco A. R. Pereira e Antônio L. Beraldo (2008). O livro é, provavelmente, a publicação mais importante sobre bambu escrita em língua portuguesa, pois fornece uma visão geral de todos os aspectos relacionados à planta e seus usos.

A segunda abordagem, que é constantemente mencionada no decorrer dos demais capítulos, trata das caraterísticas físicas, químicas e mecânicas do bambu, em escala microestrutural, definindo a composição celular, e em escala macroestru- tural, categorizando sua morfologia, única na natureza.

O bambu é um material natural com uma distribuição dos tecidos muito singular e, de certa forma, muito simples de ser entendida. Seu comportamento é influenciado por estímulos e reflete sua estrutura microscópica. Tais reflexos, que surgem de modo específico ao ser exposto a determinados contextos, podem ser explicados a partir do ponto de vista celular.

Através das definições, busca-se uma categorização das propriedades do bambu, permitindo que seja considerado um material adequado para ser utilizado em edificações, cumprindo com uma das exigências de desempenho mais, que é a estabilidade ou segurança estrutural. O livro The Anatomy of Bamboo Culms (1998), de Walter Liese, explica detalhadamente todos os aspectos constitutivos utilizando-se colmos de bambu, sendo esta obra citada por outros autores. Também são de grande 
ajuda os vários estudos do Professor Khosrow Ghavami, que permitem entender o comportamento mecânico deste compósito natural.

Os processos aos quais o bambu é submetido antes de sua utilização em obra, são abordados no terceiro capítulo, incluindo plantio, crescimento e colheita dos colmos, etapas cujo entendimento é essencial por ser o período no qual o bambu é definido anatomicamente.

Cabe destacar que, por ser um material orgânico, é facilmente biodegradável, podendo ser alvo de ataques de agentes bióticos e abióticos logo após o corte, levando à sua deterioração através do comprometimento de suas estruturas celulares e, consequentemente, modificando sua composição física, diminuindo sua capacidade de resistência mecânica.

Assim, garantir a conservação das características físicas do material, estendendo sua longevidade ao máximo, é outra das exigências básicas em rela- ção ao bom desempenho construtivo.

Para cumprir com requisitos da durabilidade, o bambu deve ser submetido a diferentes tratamentos que visam tornar seus tecidos mais resistentes, com capacidades de repelir agressões biológicas. A este respeito, o livro Bambu com Sal: Aqui e agora, lá e então (2014), escrito por Antônio Luiz de Barros Salgado, é uma obra que disponibiliza muitas informações, além de mostrar detalhadamente muitos dos procedimentos preliminares de obra.

$\mathrm{Na}$ quarta abordagem, busca-se apresentar meios de garantir estabilidade e durabilidade do material, mostrando que a qualidade do material não depende apenas do cuidado dispendido pelos produtores no manejo, de fato fundamental neste quesito, mas também das ações do arquiteto, no que tange as garantias de desempenho construtivo.

É atribuição do responsável pelo projeto entender quais característi- cas têm que possuir os elementos que conformam uma estrutura e sob que critérios devem ser combinados para que sejam atendidos os padrões mínimos de qualidade construtiva.

No caso das estruturas de bambu, os elementos que garantirão a integridade dos colmos, assim como do conjunto arquitetônico em si, são as conexões. Os vínculos entre as peças de bambu têm a função de transmitir os esforços na medida e direção prescritas, podendo exercer tensões que podem resultar em falhas estruturais.

Tais falhas físicas causadas por ação de tensões acima dos limites toleráveis, podem ocorrer de maneiras diversas, geralmente manifestando-se através de fendas na superfície do colmo.

Este fenômeno, conhecido como fendilhamento, reflete uma tendência natural, sendo a característica mais desfavorável do bambu. Por conta dele, praticamente todos os 
princípios aplicados no design de conexões e no cálculo das estruturas visam evitá-lo, afim de garantir a estabilidade do sistema. A este respeito, o livro Designing and building with bamboo (2000), escrito por Jules J. A. Janssen, no qual são explicadas várias técnicas e critérios utilizados para construir estruturas e componentes arquitetônicos de bambu, norteou a análise sobre este tema.

$\mathrm{O}$ assunto do quinto capítulo corresponde à uma abordagem prática fundamentada nos precedentes teóricos estudados, que, a partir da observação de exemplos arquitetônicos construídos, almeja identificar e descrever as manifestações patológicas que possam comprometer o desempenho construtivo, averiguar as origens das patologias, os mecanismos de ocorrência, bem como propor soluções preventivas ou corretivas, visando as melhores práticas construtivas.

A principal manifestação patológica apresenta-se através das fen- das na direção axial que ocorrem na superfície do colmo. Estas fraturas podem ter origens diversas, dependendo do contexto no qual o sistema estrutural se insere. Sendo assim, é importante identificar-se a causa e os meios de propagação para que o melhor método corretivo possa ser escolhido.

Os exemplos selecionados são construções nas quais o bambu é utilizado em sua forma natural roliça, destacando-se como elemento portante principal de sustentação da cobertura.

O livro Bamboo: The Gift of Gods (2003), de Oscar Hidalgo-Lopez, que é uma publicação em inglês muito extensa e minuciosa, abrange todos os aspectos relacionados à utilização do bambu, explorando consideravelmente seu potencial, sobretudo ao ser utilizado na construção civil. Esta obra foi utilizada intensamente ao longo da dissertação, sendo referência recorrente nos cinco capítulos.

\section{Objeto do estudo}

O objeto de estudo desta dissertação é o bambu em sua forma natural, utilizado como matéria-prima para construção de estruturas arquitetônicas.

\section{Objetivos da dissertação}

A dissertação tem como objetivo geral avaliar a evolução do desempenho construtivo do bambu em estruturas de cobertura ao longo do tempo.

A pesquisa tem como objetivos específicos:

- Categorizar os condicionantes internos e externos que validam o bambu como material estrutural;

- Avaliar o comportamento do material em construções consolidadas;

- Desenvolver novos parâmetros de projeto, contribuindo para evolução e melhora dos sistemas construtivos atuais. 


\section{Procedimentos metodológicos}

A primeira fase compreende o conhecimento extensivo, procurandose compreender a realidade global e brasileira em relação ao uso de bambu em sistemas estruturais. Nesta fase tentar-se-á:

- Analisar o contexto sociocultural relacionado à sua utilização;

- Definir as caraterísticas e propriedades do material;

- Identificar os processos prévios à sua utilização no canteiro, que afetam seu desempenho;

- Detalhar os elementos componentes e os princípios construtivos que norteiam a concepção de estruturas em bambu.

A segunda fase compreende o conhecimento intensivo, que implica em estudar in loco o desempenho técnico e construtivo de construções realizadas com bambu, datando ao menos cinco anos completos desde sua finalização.
Esta fase consistirá em:

- Analise de desempenho construtivo da cobertura da Sala de Diálogos de Verão, da Instituição Amana Key em Cotia (SP), realizada pelo escritório Amima Arquitetura;

- Análise de desempenho construtivo da cobertura do Centro Cultural Max Feffer, em Pardinho (SP), também realizada pelo escritório Amima Arquitetura. 


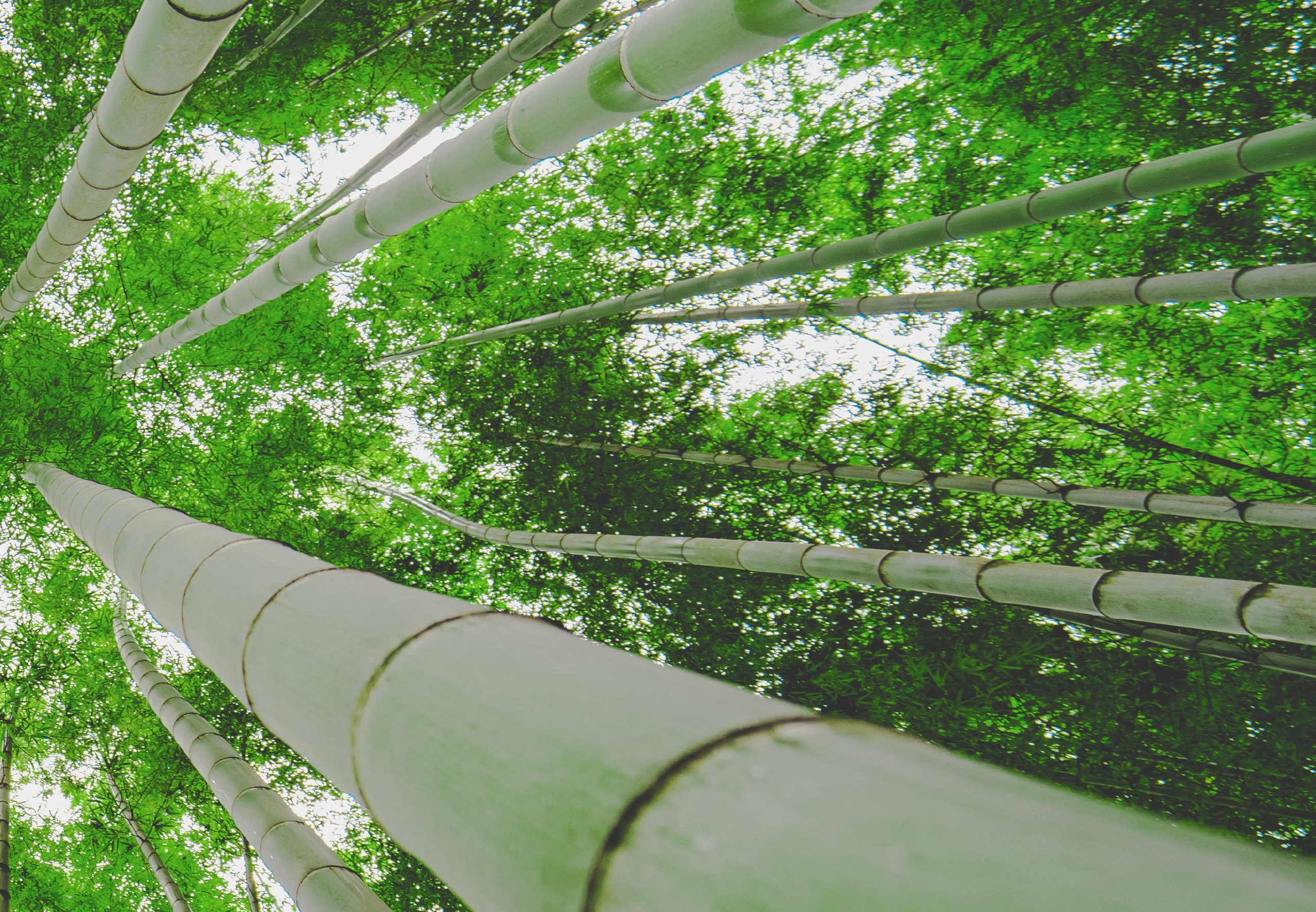




\section{Capítulo 1 \\ Dimensão sociocultural \\ e botânica do bambu}

O mundo no século XXI enfrenta desafios globais expostos e problematizados já nos fins do século XX, o maior dos quais é a própria sobrevivência após os excessos cometidos após a Revolução Industrial e as políticas desenvolvimentistas conduzidas principalmente pelo bloco de países ocidentais chamados de "Primeiro Mundo".

O consumo abusivo de recursos energéticos, como a queima de combustíveis fósseis e a consequente emissão de gases que potencializam o efeito estufa, elevando a temperatura da atmosfera a níveis catastróficos o tão conhecido aquecimento global -, é talvez o problema ecológico mais difundido. Contudo, existe outro viés da pegada da espécie humana na Terra, que levanta uma questão não menos transcendental, mas relacionada à persistência da raça humana: o de como conseguir garantir os recursos necessários para a vida da população atual sem comprometer os recursos da população por vir. Eis que surge o conceito tão repetido chamado "desenvolvimento sustentável”.

Segundo o Relatório Brundtland para as Nações Unidas, em 1987, definiuse como desenvolvimento sustentável o suprimento das necessidades de gerações presentes sem afetar a habilidade de as gerações futuras suprir as suas.

A maioria dos recursos tanto materiais como energéticos utilizados pela humanidade provém de fontes finitas, porém, a lógica atual do sistema socioeconômico global (capitalismo) é a do crescimento infinito. Essa contradição sistêmica entre o modelo produtivo teórico e as restrições da exploração dos recursos na prática supõe uma contenda que tem que ser corrigida em todos os âmbitos da sociedade.

Apesar do comprometimento feito pelos organismos estatais durante os eventos da Cúpula Mundial sobre o Desenvolvimento Sustentável, como Rio-92, Joanesburgo-2002 e Rio-2012, não há determinações claras para cumprir as agendas propos- 
tas, seja por incompetência ou omissão no momento de introduzir uma regulamentação adequada, para que os setores agrícolas, indústrias e de serviços reduzam e/ou reparem esse excesso de recursos mal consumidos.

\section{1}

\section{A arquitetura sustentável}

Devido à quantidade de recursos diretos e indiretos que são consumidos e à quantidade de resíduos que produz, a construção civil é uma das atividades humanas que produz o maior impacto no meio ambiente.

Com esse panorama, torna-se responsabilidade dos consumidores finais ou intermediários, neste caso, arquitetos e engenheiros, a consciência da importância do papel que desempenham na tomada de decisões de projeto e como essas decisões estão diretamente ligadas ao impacto ambiental que a construção vai gerar no território.

A arquitetura pode contribuir na criação de entornos e habitats mais sustentáveis, mas não pode resolver por si só os problemas do meio ambiente (EDWARDS, 2005).

Segundo Vélez (2000), um dos arquitetos e disseminadores da cultura construtiva moderna com bambu, a sustentabilidade na arquitetura deve ser considerada e pensada no ciclo completo da sua constituição, desde a fase de projeto, de execução da obra, durante o uso e na fase de demolição. Sempre de forma transversal com outros aspetos relevantes, como o entorno, o edifício e o seu funcionamento, os materiais utilizados e - finalmente e não menos importantes - os aspectos socioculturais.

A crescente relevância do entorno deve-se à pertinência de aproveitar ao máximo as condições geoclimáticas favoráveis e evitar e se proteger das desfavoráveis. Isso é conhecido como arquitetura bioclimática. A eficiência do edifício e o seu funcionamento abrange desde os sistemas passivos projetados para a captação ou proteção dos ganhos energéticos e os sistemas ativos de captação energética até o uso responsável e consciente por meio do qual o usuário final vai usufruir do edifício. Outro aspecto fundamental do entorno são os recursos materiais que oferece. Esses recursos materiais devem ser abundantes, com boas qualidades ecológicas, e, sobretudo, devem tentar ser reutilizáveis ou, no pior dos casos, recicláveis. Devem ter boas condições de segurança e salubridade, sendo necessário que na produção, processamento, transporte e execução em obra tenham o mínimo impacto ambiental, ou seja, mínimo consumo energético e de água e mínima geração de resíduos. Basicamente precisam ser parte ativa da corrente arquitetônica "verde" que se promoveu durante a $7^{\text {a }}$ Bienal de Arquitetura de Veneza, que tinha como lema: "Less esthetics, more ethics".

Nessa busca por materiais e tecno- 
logias com impacto nulo ou positivo tende-se a procurar e apreender de experiências vernaculares, de culturas e povos que não haviam sido contagiados pelo paradigma modernista da construção civil. Dessa maneira, surgem ou são redescobertos materiais renováveis, como o bambu e outros.

1.2

0 bambu como material alternativo

O bambu é um vegetal que cresce principalmente nas regiões dos trópicos (Figura 1). Há séculos é utilizado em vários países, principalmente do Leste Asiático. Também existe de forma abundante no Brasil, mas não se tem o mesmo conhecimento sobre as infinitas possibilidades da planta como há na China, Índia, Japão e em outras culturas milenares asiáticas.

Por se tratar de uma planta tropical, perene, renovável e que produz colmos anualmente sem necessidade de replantio, o bambu apresenta um grande potencial agrícola. Além de ser um eficiente sequestrador de carbono, apresenta excelentes caraterísticas físicas, químicas e mecânicas. Pode ser utilizado em reflorestamentos, na recomposição de matas arbóreas, e também como protetor e regenerador ambiental, bem como pode ser empregado em diversas aplicações ao natural ou após sofrer um adequado processamento. (PE- 
REIRA; BERALDO, 2008)Considerado em muitos países a "madeira dos pobres", o bambu apresenta características mecânicas que the outorgam o apelido de "aço vegetal". Seu crescimento e produção apresenta valores de custos muito baixos, em comparação a outros recursos florestais renováveis. Algumas espécies atingem, em entre seis e oito meses, altura e dimensões máximas e, a partir do terceiro ano, desenvolvem o maior potencial mecânico (PEREIRA; BERALDO, 2006).

Além das qualidades que o material apresenta, seu plantio oferece contrapartidas ecológicas muito interessantes, pois a planta tem um balanço positivo na relação $\mathrm{O}_{2}$ emitido e $\mathrm{CO}_{2}$ consumido, contribuindo para diminuir o excessivo "aporte" humano de dióxido de carbono na atmosfera. Janssen (2000) estima em 17 toneladas o carbono sequestrado por hectare a cada ano. Além disso, Salgado (2014) afirma que é a planta com o crescimento mais veloz do planeta, permitindo colher $30 \mathrm{t} / \mathrm{ha}$ anualmente com um adequado sistema de cultivo.

O International Network for Bamboo and Rattan (INBAR), em seu informe anual de 2015, descreveu os impactos socioeconômicos que o uso do bambu pode ter nas comunidades dos países produtores:

1) A crescente demanda global dos consu- midores por produtos sustentáveis pode ser aproveitada pelas comunidades locais para trazer inovações a partir do material.

2) A promoção, criação e desenvolvimento de novos negócios associados ao material em si e à cadeia produtiva do material.

3) O rápido crescimento da planta permite um manejo e colheita muito mais rentável que outras madeiras, assim como limita a exposição a certos desastres naturais e supõe uma boa solução para limitar a degradação do solo.

4) A estrutura morfológica da planta permite que seja cultivada em terrenos problemáticos, com topografias muito acidentadas. E sua estrutura subterrânea de rizomas e raízes permite regular $o$ fluxo d'água prevendo a erosão do solo.

A implantação de políticas que incentivem o cultivo do bambu nas comunidades locais de países tropicais em vias de desenvolvimento é essencial, porque representam os primeiros passos no processamento e transformação do bambu na cadeia produtiva e de comercialização, que permitirá utilizar esse recurso vegetal abrangendo não só a escala regional como na escala global. Todavia Frey e Von Schaewsen (2013) relatam o problema que, segundo Simón Vélez, existe na Colômbia por exemplo, onde o controle estatal ou privado de florestas inviabiliza o consumo do recurso por parte de populações rurais. Esse controle é feito por meio de uma forte normativa ambiental que onera tanto os produtores como os consumidores.

Sendo uma planta tão disseminada no globo, é fácil achá-la em fazendas ou em plantações cultivadas, porém a maior quantidade de bambu ainda se encontra em entornos naturais, o que dificulta a sua extração. Pode-se citar o estado do Acre, onde, segundo Silveira citado em Ferreira (2014), calcula-se que 59\% da vegetação que constitui as florestas é de bambus.

No mundo, as florestas de bambu ocupam uma área de 14 milhões de hectares (Embaye, 2003 apud Salgado, 2014) e geram um comércio mundial de US\$ 4,5 bilhões (Campos et al., 2003). Janssen (2000) tem uma estimativa muito maior e calcula que o mercado de bambu - apesar de ser informal em muitos casos - movimenta uma quantidade de US\$ 10 bilhões anuais.

No Brasil, o bambu era utilizado pelos povos indígenas para construções de malocas, cabanas, habitações em geral, instrumentos domésticos, de caça e vestimentas, recebendo nomes como taquara, taboca, jativoca, taquaruçu, taboca-açu.

O bambu chega a ser adorado como um deus em algumas partes do mundo, principalmente na Ásia, 
onde se desenvolveram técnicas para utilizar o material para fabricar utensílios, roupas, edifícios e até para ser consumido como alimento.

\section{3}

\section{O bambu na construção civil}

Existem várias aplicações do bambu na construção civil e na arquitetura. Uma das mais difundidas atualmente é seu uso para gerar componentes à base de laminados, como chapas aglomeradas, compensados de bambu, bambu laminado e colado etc. Todos esses processados despojam a planta da identidade formal tão característica do colmo natural para transformá-la em um elemento moldável, descaracterizando a sua anatomia tão peculiar. Um dos exemplos mais conhecidos dessa utilização é o forro do Terminal 4 do Aeroporto Adolfo Suárez Madrid-Barajas (Figura 2), em Madri, projetado pelo arquiteto Richard Rogers. A tecnologia atual usada para processar e gerar componentes com base de bambu produz muito mais resíduos e consome muito mais recursos do que o uso de colmos inteiros com simples tratamentos preventivos.

$\mathrm{O}$ uso de colmos de bambu inteiros para a construção é comum

em muitas regiões do mundo, onde

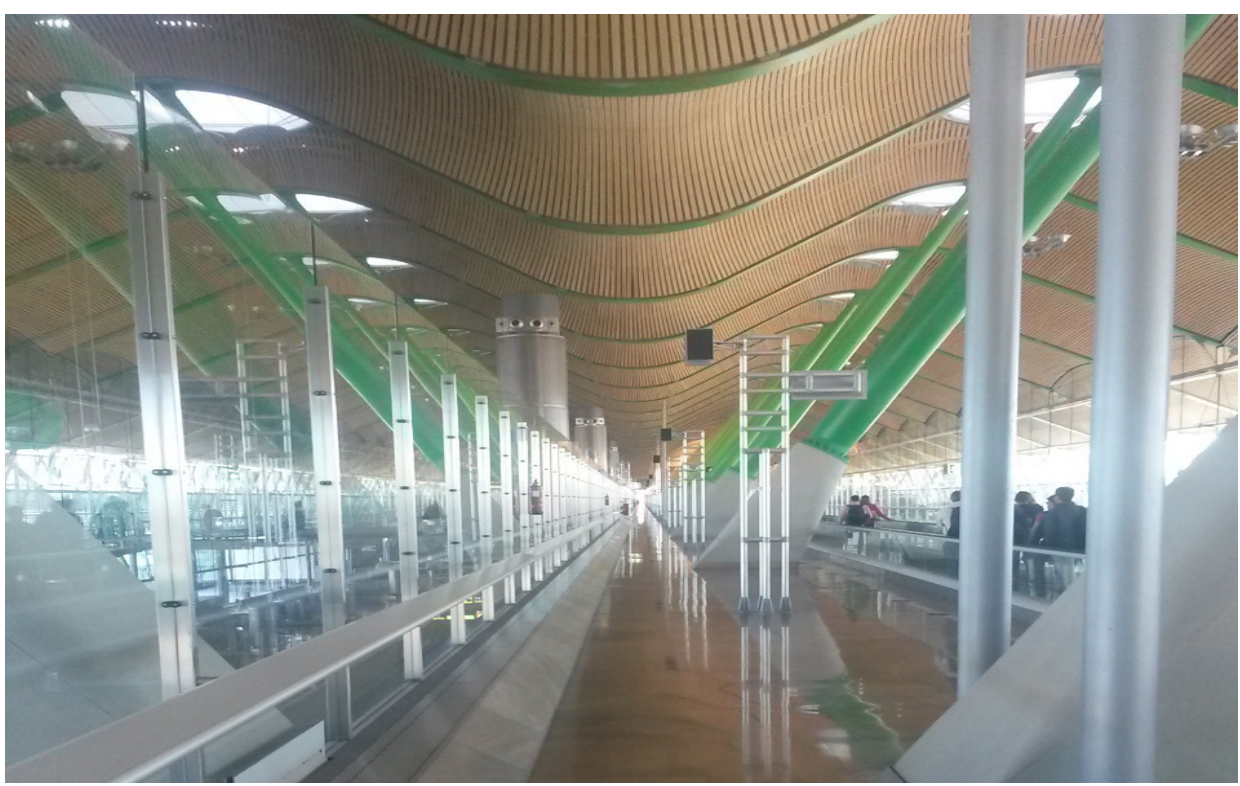


faz parte da cultura vernacular e da tradição construtiva dos povos. Entretanto, nos últimos quinze anos, muitos escritórios de arquitetura modernista e de vanguarda têm se interessado pelo material; alguns pelas propriedades mecânicas, outros pelas formais. É possível separar claramente duas correntes na utilização do bambu em escala global: a que usa o bambu como elemento envolvente e a que o utiliza como elemento estrutural.

A primeira corrente, curiosamente, corresponde aos escritórios europeus e norte-americanos. Além de responder suas arquiteturas a correntes formais muito estendidas, não conhecem as propriedades estruturais do bambu, talvez porque possuam códigos técnicos de edificação muito rígidos, em que quase se restringem os materiais estruturais ao concreto e ao aço. Usam o bambu como envolvente, principalmente como brises, para o condicionamento térmico passivo, e como revestimento ou forro.

Como refletem algumas obras, este tipo de arquitetura desmaterializada de luz e energia, se manifesta na superfície, na pele do contêiner, a escultura pós-minimalista também transferiu o significado do objeto como massa do volume à essência da própria superfície material plausível (MONTANER, 2002).

Alguns exemplos são: o edifício de habitação de Carabanchel, em Madri, desenhado pelo escritório Foreign Office Architects; o estacionamento do Zoo Leipzig dos HPP Architects (Figura 3); o San Vincenzo Camping Service dos Archea Associati, entre outros. Porém, essas obras quase sempre são únicas no portfólio desses escritórios, geralmente usam apenas uma vez esse recurso e não se aprofundam nas técnicas nem no conhecimento do material.

Do lado oposto, existem os arquitetos de países com tradição construtiva baseada nos materiais que a natureza gera. São países latino-americanos e, principalmente, do Sudeste Asiático. A construção civil nesses países não é regida por códigos técnicos tão rígidos, e se constrói de um modo muito mais tradicional, baseado na experiência. Usam o bambu com todo o potencial, explorando todas as propriedades mecânicas, conseguindo se libertar, em muitos casos, do dogmático uso dos materiais modernistas, como o concreto armado.

Vários arquitetos desses países, com uma verdadeira sensibilidade em relação ao meio-ambiente e ao

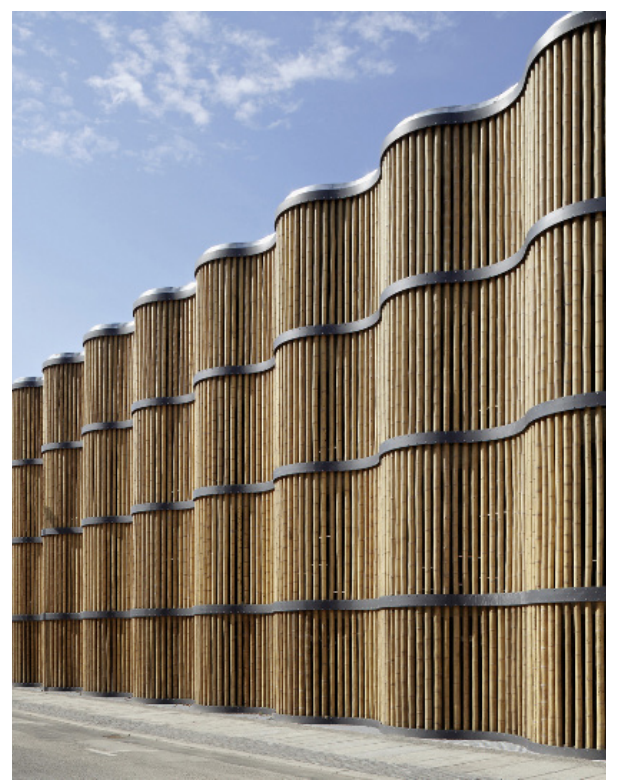

FIGURA 3

Estacionamento do Zoo Leipzig. Foto: Punctum B. Kober. 
FIGURA 4

Son La Restaurant. Foto: Hiroyuki Oki.
FIGURA 5

Biblioteca del Pueblo de Guanacas. Foto: Fabián Alzate.
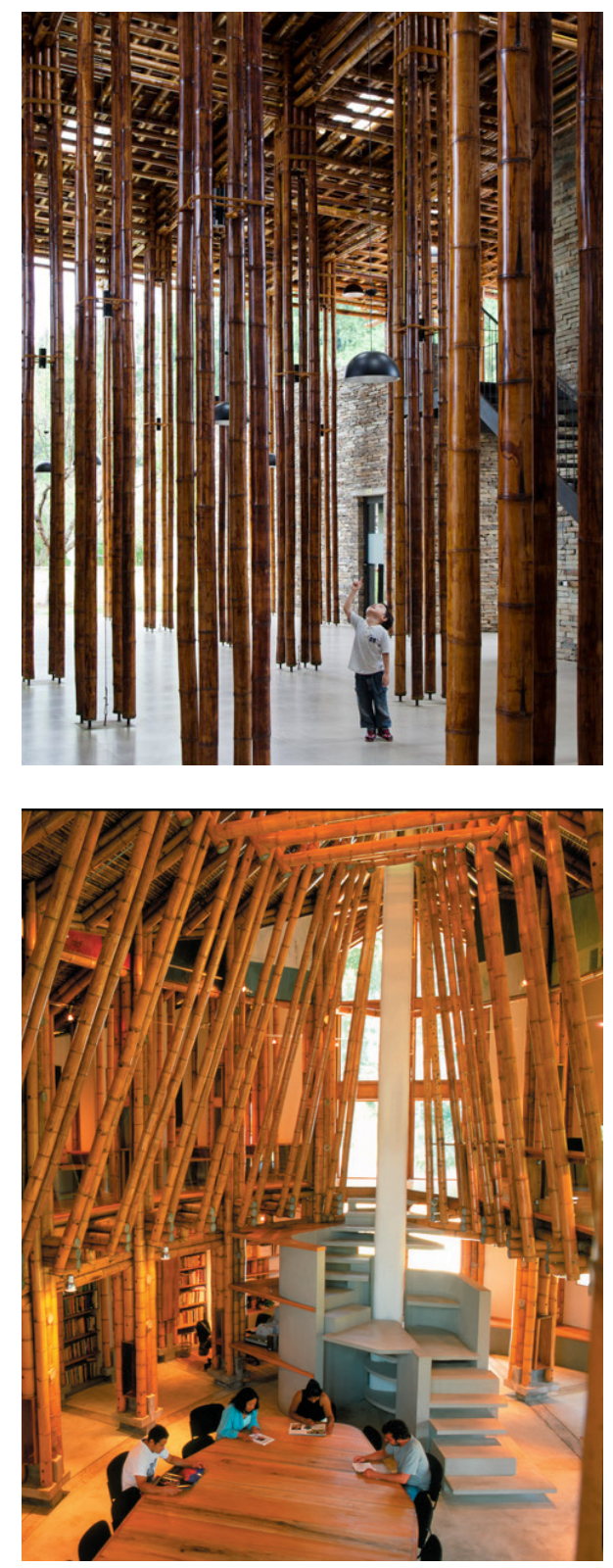

desenvolvimento sustentável, realizam propostas construtivas que se enquadram no paradigma ecológico do "Think globally, act locally". Se aproveitam do conhecimento da arquitetura vernacular para propor construções com uma linguagem modernista, na qual o respeito ao entorno é principal e o resultado formal é embasado na proposta do detalhe construtivo, o que viria a ser arquitetura low-tech. O material e a técnica são melhorados obra após obra e não são utilizados como uma experiência descartável, como algumas vezes se faz na arquitetura ocidental na experimentação com novas materialidades.

$\mathrm{O}$ arquiteto vietnamita Vo Trong Nghia é uma das principais referências asiáticas no uso do bambu, sendo criador de autênticas obras de arte com essa técnica milenar, responsável pelo Wind and Water Café em Binh Duong e pelo Son La Restaurant, também no Vietnã (Figura 4). Outra referência é a comunidade PT Bambu, autora da Green School, uma construção integral de bambu feita na Ilha de Bali na Indonésia. No Japão, o arquiteto Shoei Yoh vem há muitos anos desenvolvendo projetos espetaculares com bambu, malhas, estruturas matriciais e sistemas de cobertura muito elaborados e complexos.

$\mathrm{Na}$ América do Sul, também existe uma tradição muito forte na construção em bambu, principalmente na Colômbia, onde o material é conhecido por guadua. O principal arquiteto é Simón Vélez, talvez a figura mundial mais destacada com obras construídas por todo o mundo, como a Catedral Alterna Pereira, Museo Nómada em Zócalo (Cidade do México) e sua obra pioneira e emblemática do Pavilhão ZERI, na Expo Hannover, em 2000. Há outros talentosos arquitetos colombianos que seguem a estela do mestre como Simón Hosie, vencedor do Prêmio Nacional de Arquitetura Colombiana no ano 2004, com a Biblioteca del Pueblo (Figura 5) no vilarejo de Guanacas, na Colômbia, ou os espetaculares pedágios de bambu da estrada Pereira-Armenia.

O Brasil não é alheio a essas duas vertentes do uso do bambu: de um lado, existe um grupo de arquitetos com uma vocação fortemente ocidentalizada, com padrões modernistas do estilo internacional e que usam o material como brise, forro ou revestimento. Márcio Kogan, com a Casa Ilha Bela (Figura 6); Isay Weinfeld, com a casa Terra Nova em São Paulo; Aflalo/Gasperini, com o Serramar Parque Shopping 
em Caraguatatuba, no litoral norte paulista; entre outros que servem como exemplos de aplicações superficiais de colmos.

$\mathrm{Na}$ outra vertente, duas arquitetas são as principais referências deste mundo tão desconhecido pelos profissionais e acadêmicos. A arquiteta Celina Llerena possui diversas construções residenciais localizadas principalmente na baixada fluminense; e a arquiteta paulista Leiko Hama Motomura e seu escritório Amima Arquitetura, com obras tecnicamente muito interessantes, como o Centro Cultural Max Feffer (Figura 7), em Pardinho (SP), provavelmente a obra de arquitetura contemporânea com uso de bambu estrutural mais importante do Brasil.

A Colômbia possui maior domínio no que se refere a conhecimento, pesquisa e uso do bambu em relação ao Brasil, sendo que há grandes paralelismos entre os dois países em aspectos econômicos, sociais, culturais e climáticos. O principal fato diferenciador da Colômbia é a ocorrência de atividade sísmica que exige dos materiais certa flexibilidade para a absorção dos abalos sísmicos.

Foi a partir de um fato dramático que a Colômbia começou a tomar consciência da importância da incorporação do bambu como material estrutural na edificação, pois, após o terremoto de Armenia de 1999, perceberam que as casas em argila construídas com os sistemas tradicionais dos colonizadores espanhóis desabaram por serem rígidas demais para absorver os embates horizontais. Somente aquelas construções humildes realizadas em bambu suportaram tais tensões.

O arquiteto Simón Vélez, naquele momento, já havia trabalhado com bambu em pequenas obras e foi convidado a projetar um pavilhão para a Expo Hannover (Figura 8), em 2000, junto à Fundação ZERI (Zero Emissions Research \& Initiatives), em que o tema principal foi "Homem, natureza e tecnologia: um novo mundo nasceu", como resposta operacional e real à Declaração de Rio-92.

O pavilhão projetado por $\mathrm{Si}$ món Vélez era uma cobertura feita e sustentada por bambus e outros materiais com planta poligonal, e o resultado formal foi excelente. $\mathrm{O}$ desempenho estrutural, apesar da desconfiança dos organizadores, também foi ótimo.

Foi nesse momento que o arquiteto começou a ganhar fama e a possibilidade de desenvolver muitos mais

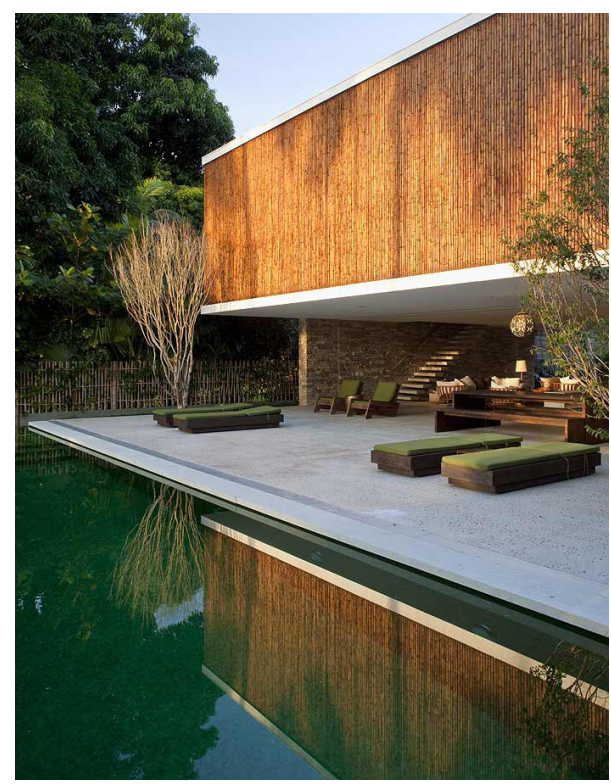

FIGURA 6

Casa Ilha Bela. Foto: Pedro Vannucchi.

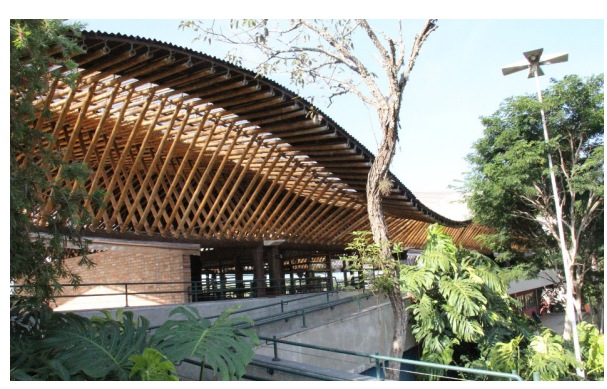

FIGURA 7

Centro Cultural Max

Feffer. Foto: Joan Font

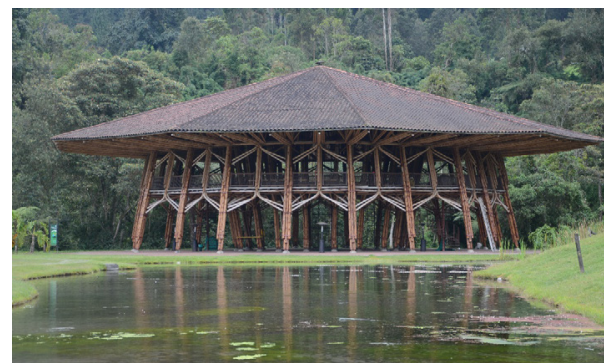

FIGURA 8

Pavilhão ZERI. Foto: Fredy Arango. 
projetos com o bambu por todo o mundo. Sempre com a caraterística formal de produzir coberturas com estruturas sequenciadas de grandes vãos, verdadeiras obras-mestras do uso e técnica do bambu. Por essa razão, Vélez passou a ser conhecido popularmente como "roof architect", denominação aplicável somente a arquitetos de países onde o clima tropical faz desnecessária a vedação total do espaço, porque não se precisa de proteção contra o frio, e, sim, que se facilite a iluminação natural e a ventilação constante (VÉLEZ et al., 2000).

\section{4}

\section{Aspectos botânicos do Bambu}

Apesar da aparência roliça, do tamanho, da consistência e da resistência do colmo formado por tecidos lenhosos, o bambu não é considerado uma árvore.

Sendo preciso, na definição botânica, o bambu é uma planta espermatófita, ou seja, produz semente a partir da divisão das angiospermas, o que quer dizer que sua semente está protegida por um fruto, e pertencente à classe monocotiledônea, da subclasse Commelinidae, da ordem das Poales e da família Poaceae. Significa que pertence à família das gramíneas, portanto pode ser considerado uma grama gigante. planta geralmente se dá pelas características florais, mas os bambus raramente florescem, e, quando se dá um florescimento, é tão insignificante que geralmente passa desapercebido, o que dificulta o trabalho dos taxonomistas.

\subsection{1}

\section{Taxonomia}

Os objetivos dos estudos taxonômicos e da classificação do bambu são os da agrupação sistemática das nomenclaturas através da geração de uma sólida classificação baseada em estabelecer atributos que reflitam a verdadeira história evolutiva da planta, assim como o desenvolvimento de caraterísticas identificadoras para uma fácil determinação da espécie.

Existem certas limitações associadas às formas tradicionais de classificação segundo Stapelton (1997):

1) as classificações baseadas na morfologia agrupam superficialmente a partir de semelhanças;

2) as classificações baseadas nas caraterísticas reprodutivas assumem uma alta significação evolutiva perante aspectos vegetativos;

3) tomam-se para estudo alguns aspectos, considerando-os artificialmente isolados, quando deveriam ser agrupados para uma correta interpretação.
Com tudo isso, Das et al. (2008) propõem, para uma correta identificação, que sejam feitos mapeamentos moleculares do DNA, a fim de obter uma classificação precisa.

Para Liese (2000), existem algumas caraterísticas anatômicas macroestruturais no bambu que podem definir a espécie:

1) a heterogeneidade dos tecidos nas camadas externas e internas das paredes podem diferenciar gêneros, assim como caraterísticas como coloração (Figura 9) e textura do córtex;

2) variações e padrões no tecido parenquimático;

3) geometria dos feixes de fibras;

4) caraterísticas dos feixes vasculares (xilema e floema);

5) estrutura dos nós;

6) caraterísticas do sistema subterrâneo.

O bambu é membro da subfamília Bambusoideae, dentro da família das gramíneas Poaceae.

A família Bambusoideae está subdividida em duas tribos: a Bambuseae (bambus lenhosos) e a Olyreae (bambus herbáceos). Cada subdivisão possui caraterísticas muito particulares (Tabela 1).

As espécies de bambu no Brasil estão distribuídas principalmente na Mata Atlântica, na Amazônia e no 


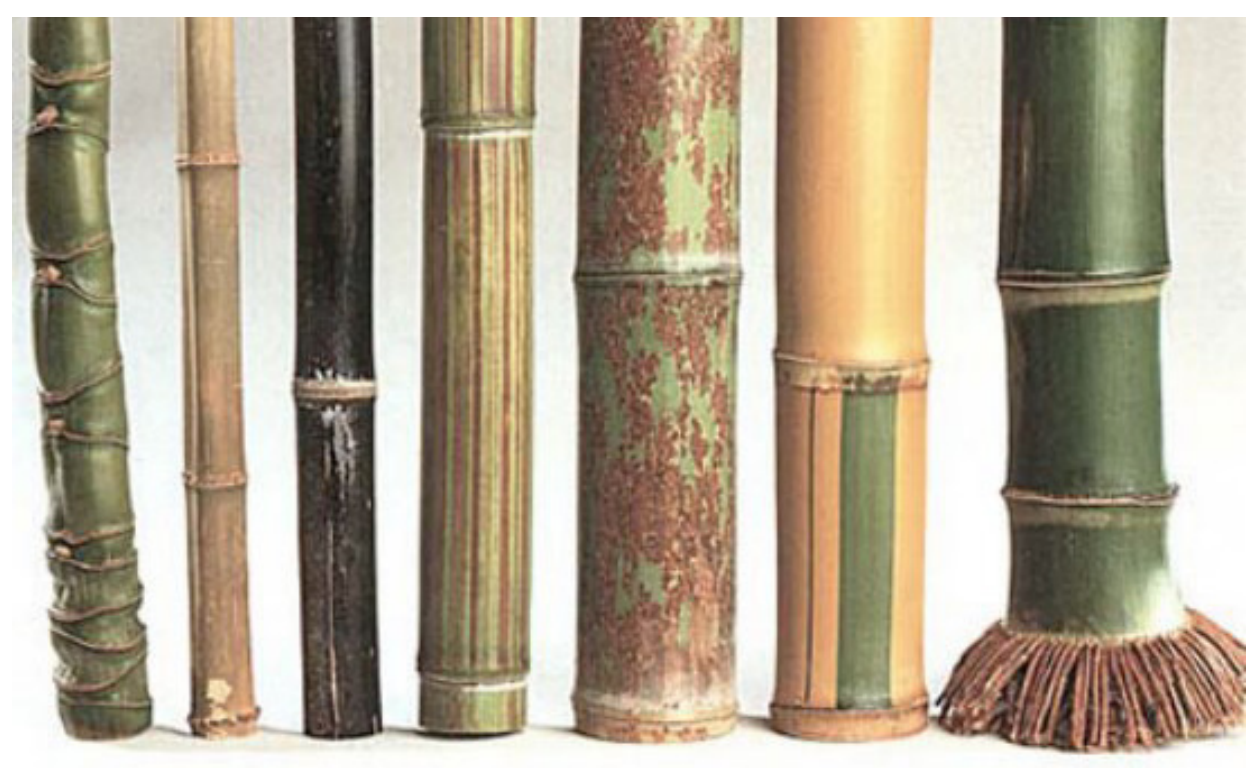

Tipos de bambus.

Foto: Wetterwald M.F.

\section{Característica}

Herbáceo

Lenhoso

\begin{tabular}{lll}
\hline Altura & Normalmente $<2 \mathrm{~m}$ & 1-35 m \\
\hline Ramificação & Simples & Complexa \\
\hline $\begin{array}{l}\text { Consistência do } \\
\text { colmo }\end{array}$ & $\begin{array}{l}\text { Não lignificado, } \\
\text { facilmente quebrável } \\
\text { com dois de dedos }\end{array}$ & $\begin{array}{l}\text { Lignificado, } \\
\text { facilmente quebrável } \\
\text { com dois de dedos }\end{array}$ \\
\hline Folhas de colmo & Ausentes & Presentes \\
\hline Lígula exterior & Ausente & Presentes \\
\hline Flores & Unissexuais & Bissexuais \\
\hline Florescimento & Contínuo (polycarpic) & Estacional(monocarpic) \\
\hline
\end{tabular}

Exposição solar direta Não tolerante
Tolerante
TABELA 1

Principais

características

distintivas dos

bambus herbáceos

e dos bambus

lenhosos. Fonte:

Filgueiras \&

Gonçalves, 2004 
Cerrado, mas nem todas são nativas. Durante a época da colonização, os portugueses introduziram várias espécies asiáticas trazidas de suas outras colônias. Espécies vindas da Índia e da China foram utilizadas para a construção civil, cercados e outros elementos, destacando-se os gêneros Dendrocalamus, Bambusa e Phyllostachys. Posteriormente, os imigrantes japoneses também introduziram no Brasil outras espécies vindas do Japão e, por estarem mais familiarizados, o cultivo e uso foram mais estendidos.

1.4.1.1

Sistemas de classificação

Segundo Das et al. (2008), os sistemas de classificação do bambu propostos até a presente data necessitam de mais apoio científico, e a delineação taxonômica em níveis mais baixos muitas vezes carece de suficiente resolução. A escassez de eventos, como a floração e a poliploidização extensiva do genoma, são desafios do grupo de bambus lenhosos. O tremendo avanço das tecnologias de marcadores moleculares mantém a promessa de lidar com as diferentes necessidades da taxonomia do bambu e os estudos de diversidade.

A taxonomia macroscópica se baseia na classificação de espécies a olho nu, observando estruturas mor- fológicas da lâmina foliar, da epiderme das lígulas, das brácteas, das espiguetas e da anatomia do colmo, e não serve para uma definição precisa de gêneros ou espécies.

Os sistemas de classificação a olho nu discriminam segundo as características morfológicas das partes do bambu. As caraterísticas da planta no nível subterrâneo e a propagação do rizoma são primordiais para diferenciar certos gêneros. O rizoma é a parte do caule subterrânea que tem crescimento horizontal, da qual frequentemente surgem brotos que posteriormente formam os colmos que se projetam telescopicamente em direção vertical no sentido ascendente; do rizoma também surgem as raízes que crescem no sentido descendente, se aprofundando no solo.

Há três grupos de bambus segundo a propagação dos rizomas. São eles:

1) Grupo monopodial (Figura 10): os rizomas são longos, delgados e cilíndricos, crescem horizontalmente sem frequência repetitiva, os colmos brotam verticalmente e sempre isoladamente. Conhecidos como bambus alastrantes, porque sua propagação é extensiva no terreno (DAS et al., 2008). As espécies que apresentam essas características se desenvolvem preferencialmente em clima temperado (PEREIRA; BERALDO, 2008).
2) Grupo simpodial (Figura 11): os rizomas deste grupo são curtos, grossos e sólidos com internós assimétricos e raízes na parte inferior. Possuem gemas que se ativam criando novos rizomas, e estes últimos crescem horizontalmente em curtas distâncias, brotando do seu ápice o colmo que se projeta verticalmente (PEREIRA; BERALDO, 2007). A proximidade dos colmos cria agrupações chamadas touceiras.

3) Grupo anfipodial: Os rizomas apresentam características híbridas dos dois grupos anteriores.

Segundo Das et al. (2008), as denominações "monopodial" e "simpodial” são relativas à morfologia real dos rizomas, porém, em ambientes científicos, prefere-se os termos "leptomorfo", para se referir ao grupo monopodial, e "paquimorfo", para se referir ao grupo simpodial, pois essas denominações são relativas ao padrão de ramificação, o que agrega mais precisão na denominação da classificação.

Outros aspectos primários para determinar a taxonomia do bambu e diferenciar gêneros e espécies são a ramificação, a brotação e as características das folhas. Os bambus de clima tropical têm padrões de ramificação ancestrais e básicos; por outro lado, os bambus 
de clima temperado podem apresentar padrões básicos ou complexos na ramificação (MCCLURE, 1966 apud DAS et al., 2008).

Existem dois tipos de folhas no bambu, as folhas de colmo também conhecidas como bainhas, que protegem o colmo durante o crescimento, e as folhas verdes, que têm como função principal a realização da fotossíntese.

Segundo Das et al. (2008), as folhas verdes podem servir como caraterísticas básicas para identificação em observações em campo até o nível de subtribo, daí outras especificidades morfológicas botânicas mais precisas, como a presença ou ausência de lígulas abaxiais podem servir para determinar a espécie.

Observando a floração, pode-se distinguir três tipos de bambu: os que têm floração anual, os de floração esporádica ou irregular e os de floração gregária, que florescem em largos intervalos de tempo sincronizados com a produção de sementes. Segundo Janzen (1976), a maioria dos bambus lenhosos pertence ao terceiro grupo, com períodos de floração que podem ir dos 3 aos 120 anos. As características da flor, assim como certos atributos do fruto, também são aspectos que especialistas em taxonomia consideram para poder diferenciar as espécies.

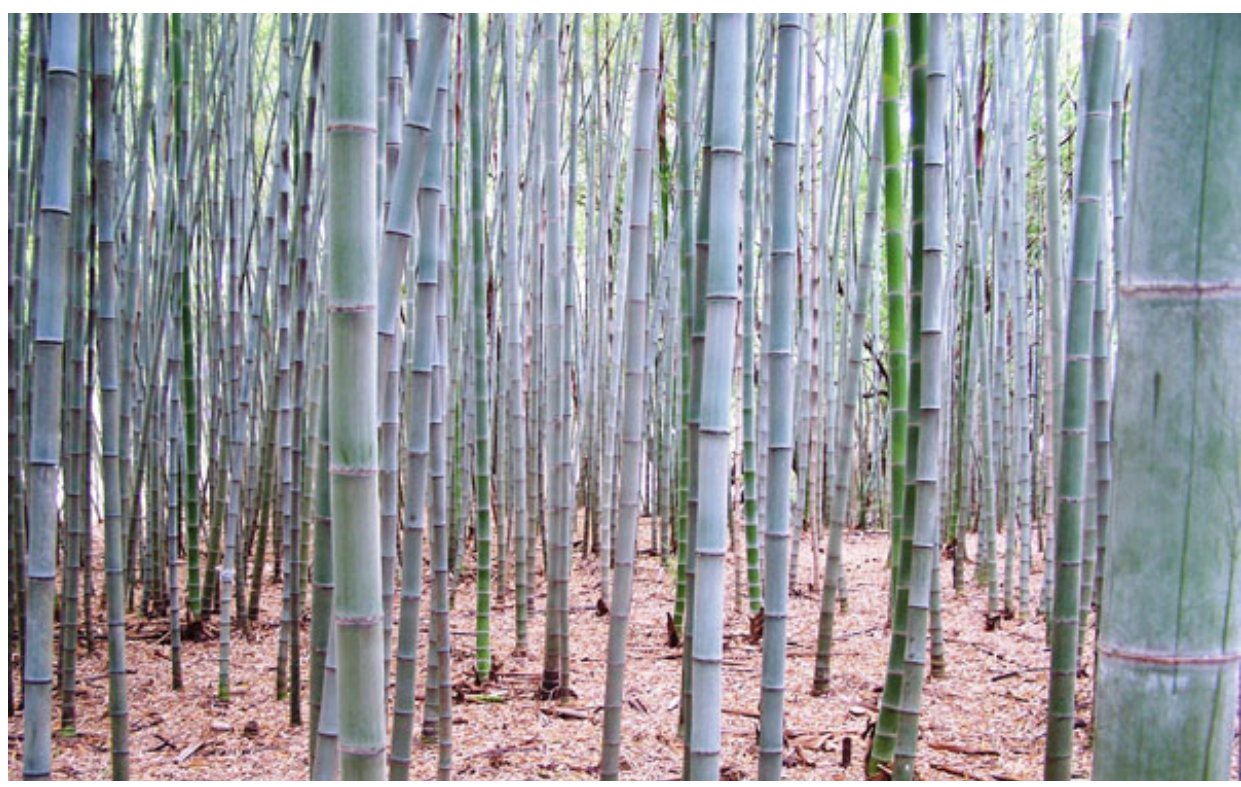

FIGURA 10

Bambu monopodial Phyllostachys pubescens (mossô). Foto: autor desconhecido. Disponível em: <http://www. bambooaustralia. com.au/wp-content/ uploads/2013/06/ Phyllostachys-pubescens-Moso.jpg>. Acesso em mar. 2017.

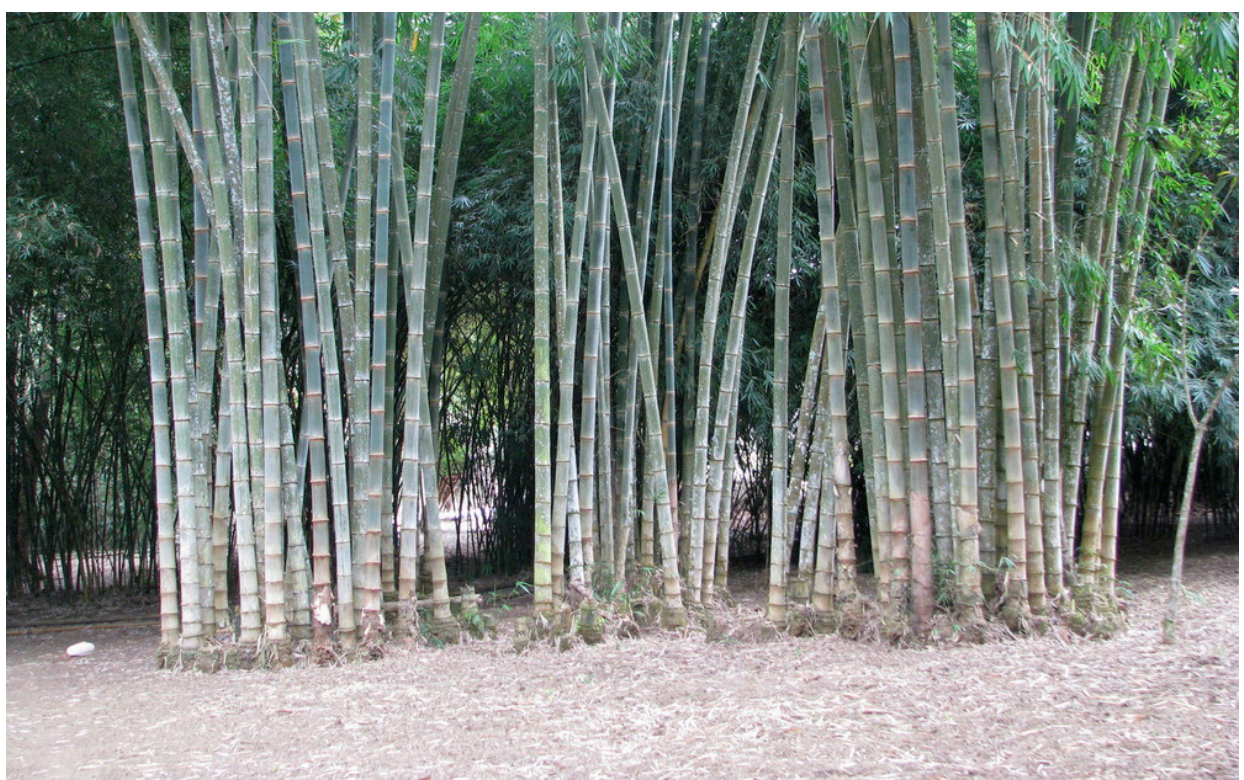

FIGURA 11

Touceira de bambu Dendrocalamus asper. Foto: Bambubo (flickr.com). Acesso em mar. 2017. 
A classificação realizada por Das et al. (2008), baseada nos sistemas de classificação mais avançados de Dransfield e Widjaja (1995), Li (1997) e Soderstrom e Ellis (1987), a tribo dos bambus lenhosos (Bambuseae) contém nove subtribos, contendo estas subtribos 67 gêneros.

1) Subtribo Arthrostylidiinae;

2) Subtribo Arundinarineae;

3) Subtribo Bambusineae;

4) Subtribo Chusqueinae;

5) Subtribo Guaduinae;

6) Subtribo Melocanninae;

7) Subtribo Nastinae;

8) Subtribo Racemobambosinae;

9) Subtribo Shibataeinae.

1.4.1.2

Distribuição geográfica

Segundo Filgueiras e Gonçalves (2004), existem no mundo cerca de 1.250 espécies distribuídas em 90 gêneros. Essas cifras estão em constante mudança devida às novas definições na caracterização do bambu, ou à aparição de novas espécies que são descobertas em florestas e ecossistemas não explorados.

Há bambus nos cinco continentes, mas só a Europa não possui espécies nativas. Qualquer bambu encontrado nesse continente é tido como exóti- crescimento de espécies temperadas. Crescem naturalmente do paralelo $51^{\circ}$ Norte ao $47^{\circ} \mathrm{Sul}$, e do nível do mar até os $4.300 \mathrm{~m}$ de altitude (LONDOÑO apud VILLEGAS, 2003).

Estudos taxonômicos do genoma dos bambus apresentados pelo Bamboo Phylogeny Group (2012) mostram diferenças entre os bambus da América e os do resto do planeta, devido ao seu grau de evolução. As espécies de bambu paleotropical são africanas, asiáticas e da Oceania; os bambus neotropicais, com um grau de evolução mais avançado, são encontrados nas Américas (Figura 12).

Com base nos estudos realizados, Londoño (2002) determinou que a América Latina possui 20 gêneros e 429 espécies nativas de bambu lenhoso. Já para Hidalgo-Lopez (2003), nas Américas existem 440 espécies nativas, das quais 320 são do tipo lenhoso e 120 do tipo herbáceo, porém $95 \%$ das espécies nativas não têm uma aplicação direta para a construção. Apenas 15 espécies, que correspondem a, aproximadamente, $5 \%$ do total, são consideradas as melhores espécies endêmicas do continente, e todas pertencem ao gênero Guadua, principalmente pelo seu potencial industrial e na construção civil. No entanto, devido à deflorestação, só restam oito espécies dessas 15.
Em escala comercial, o cultivo de bambu na América Latina está limitado a algumas espécies nativas e outras exóticas, como a Guadua angustifolia Kunth comumente chamada guadua, a Bambusa vulgaris, Bambusa tuldoides, Phyllostachys aurea (cana-da-índia) e Phyllostachys pubescens (mossô).

O Brasil é o pais com maior diversidade e maior porcentagem de espécies endêmicas, com um total de 137 espécies divididas em 17 gêneros diferentes (LONDOÑO, 2002).

Nos estudos realizados por Filgueiras e Gonçalves (2004), afirma-se que no Brasil há 34 gêneros e 232 espécies, das quais 174 são consideradas endêmicas, 16 dos gêneros achados são do tipo herbáceo, e 18 do tipo lenhoso. No território brasileiro, encontram-se $89 \%$ de todos os gêneros e $65 \%$ de todas as espécies de bambus conhecidos na América Latina, porém a maioria das espécies nativas brasileiras está enquadrada na categoria de espécies arbustivas. As espécies de bambu nativas estão distribuídas nos três biomas mais extensos do território nacional, na Mata Atlântica, na Floresta Amazônica e no Cerrado (Tabela 2), mas, ao longo de todo o território brasileiro, há bambus inseridos pelo homem nas florestas (Figura 13). 


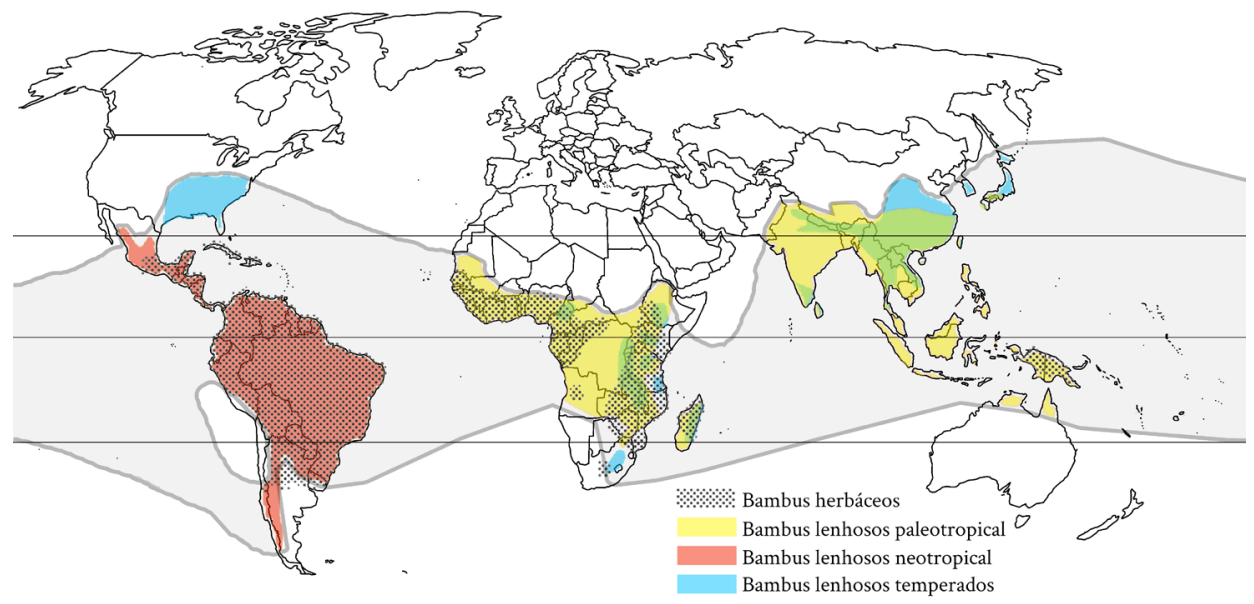

FIGURA 12

Distribuição geográfica bambu. Foto: Joan Font com base nas imagens de Elisabeth Vogel.

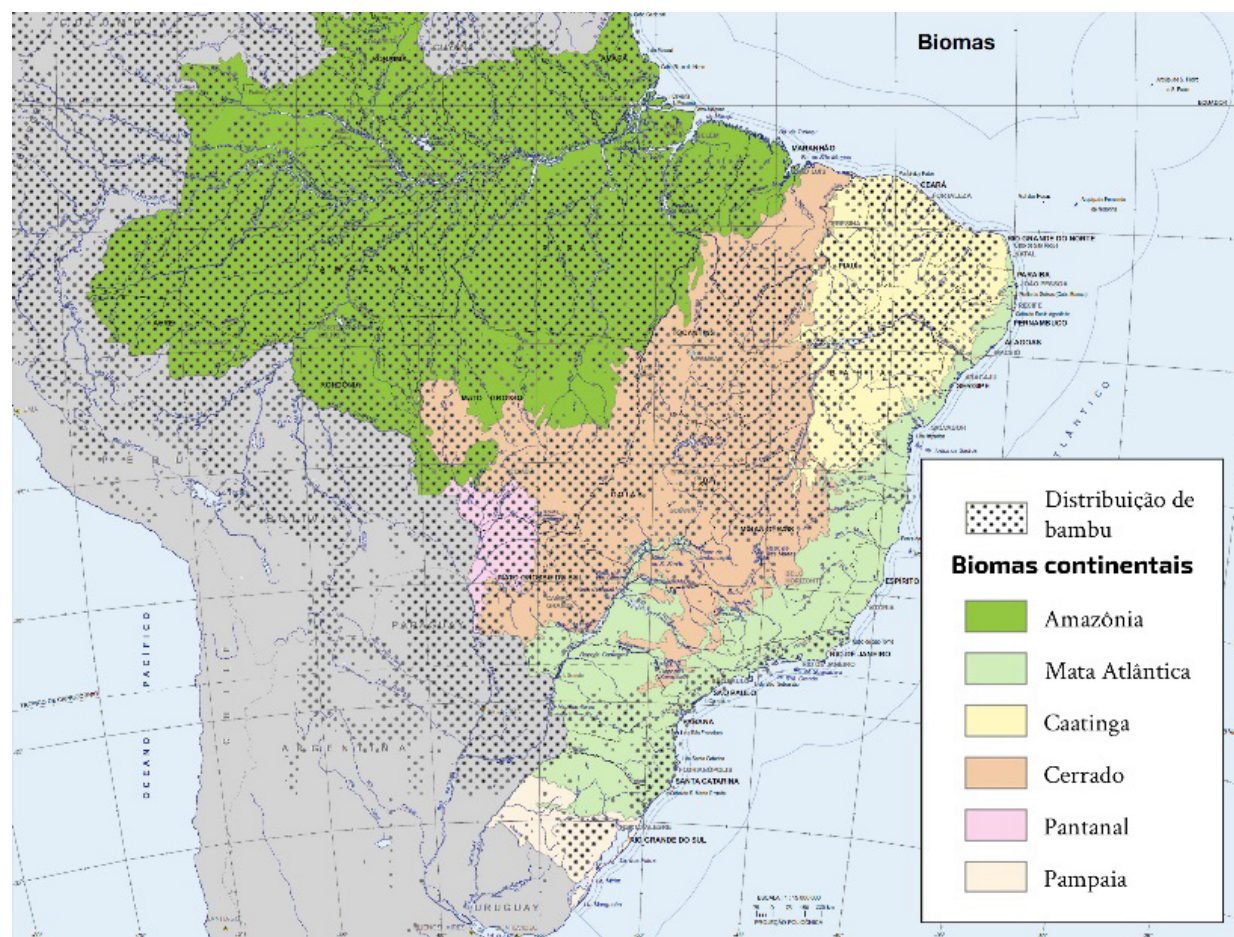

\begin{tabular}{ll} 
Bioma & Herbáceo \\
\hline Mata Atlântica & 151 \\
\hline Amazônia & 60 \\
\hline Cerrado & 21 \\
\hline TOTAL & 232
\end{tabular}

FIGURA 13

Distribuição de bambu nos biomas do Brasil. Foto: Joan Font com base na imagem disponível em: <http://www. mapas-brasil.net/ biomas.htm>. Acesso em mar. 2017.

\section{TABELA 2}

Distribuição das espécies entre os biomas brasileiros. Fonte: Filgueiras \& Gonçalves, 2004. 
No Brasil, os gêneros Bambusa e Dendrocalamus, apesar de serem espécies exóticas, são as que participam de uma cota de mercado maior para uso no setor de construção, fabricação de mobiliário e produção de celulose para papel.

Embora o bambu tenha múltiplas finalidades, e devido às grandes diferenças estruturais da morfologia da planta, nem todas as espécies são adequadas para serem utilizadas na construção civil. No Brasil, os gêneros mais comuns utilizados na engenharia civil são Bambusa, Dendrocalamus, Gigantochloa, Guadua e Phyllostachys. Todas as espécies que possuem atributos ideais para a construção civil são da tribo dos bambus lenhosos.

Alguns organismos internacionais recomendam a introdução e proliferação de algumas espécies chamadas prioritárias, que, com base em critérios como valor agregado, facilidade de manejo, facilidade de adaptação a condições climáticas entre outros, determinam que possuem um grande potencial como recurso natural.

Segundo Londoño (2002), a destruição de ecossistemas onde é achada a maioria das espécies nativas demanda uma intensa campanha para proteção desse vegetal.

1.4 .2

\section{Morfologia}

O bambu é uma planta perene constituída por um sistema ramificado de eixos vegetativos segmentados formados por uma alternância regular de nós e intrenós.

\section{4 .2 .1 \\ O colmo}

É o eixo aéreo segmentado da planta. O colmo de bambu tem a forma geométrica de um tronco de cone, costuma ser oco, e com uma sequência regular de nós e internós. Os nós são centros de grande atividade morfogenética, da qual os ramos ou as raízes emergem.

Segundo Liese (1998), o nó é formado pela cicatriz da bainha, a aresta nodal, o diafragma e a parte superior do diafragma. Já para Salgado (2014), no nó existe o anel nodular, o anel de bainha e as gemas dormentes, que são os locais de emergência do novo crescimento segmentado.

Os internós são delimitados externamente pelas cicatrizes das bainhas. Os internós costumam ser mais compridos no terço intermediário do colmo do que no terço basal e no terço apical (Figura 14).

Internamente, o colmo é dividido pelos diafragmas, e a parede do colmo pode variar de espessura dependendo da espécie. Há, aliás, bambus sem internós ocos, ou seja são maciços, é o caso do Dendrocalamus strictus.

1.4 .2 .2

A base do colmo

É a parte subterrânea que faz a transição entre o colmo e o rizoma. Tem largura maior que o colmo e é constituída por algumas dezenas de nós juntos amontoados e de onde crescem algumas gemas e raízes (YANG; HUI, 2010).

1.4 .2 .3

Colo do rizoma

Parte da base do rizoma mais delgada, que conecta a base do colmo a outro rizoma pela gema de onde nasceu. É formado por uma dezena de nós amontoados e não possui raízes nem gemas (YANG; HUI, 2010).

A distância dos colmos nas touceiras depende do comprimento do colo do rizoma. Em algumas espécies, como a G. angustifolia, o colo do rizoma é tão comprido que o espaçamento dos colmos aéreos faz interpretar que se trata de uma espécie alastrante, quando, na verdade, é uma entouceirante. 
1.4 .2 .4

Rizoma

O rizoma é a parte subterrânea que tem função de fundação estrutural. É também responsável pela reprodução através da ramificação e tem função de armazenamento e transporte de nutrientes. Os dois grandes grupos de bambu segundo seu sistema de propagação, paquimorfo e leptomorfo, têm em comum a anatomia do colmo e seu processo de crescimento (YANG; HUI, 2010).

O grupo leptomorfo resiste a temperaturas baixas e, por isso, é encontrado em regiões de clima temperado. Seu rizoma é cilíndrico delgado e corre paralelo à superfície do solo. A rede de rizomas subterrâneas do bambu previnem colapsos de solo e deslizamento.

$\mathrm{O}$ grupo paquimorfo, entouceirante ou simpodial, é típico de regiões tropicais e se caracteriza por não ter base do colmo, portanto, cresce diretamente do rizoma, que se considera em si a própria base do colmo.

Os rizomas deste último grupo são sólidos com raízes na parte inferior, têm forma curva e largura superior ao colmo que dele nasce e possuem botões laterais dos quais brotam somente outros rizomas.

Algumas espécies de bambu, como a G. angustifolia, são do tipo entouceirante, mas, aparentemente pela distância entre os colmos, pode-se interpretar que é alastrante. Isso se deve ao comprimento do pescoço do rizoma, que é tão longo que define uma distribuição da parte aérea da planta muito espalhada. Outras espécies, como a Chusquea fendleri, são do tipo metamorfo, como é descrito por Hidalgo-López (2003).

1.4.2.5

Ramificação

Os ramos surgem das gemas dos colmos situadas nos nós e é de onde crescem as folhas. Os ramos são estruturas secundárias semelhantes aos colmos, só que mais finas e possuem nós e internós. Cada espécie de bambu tem seu padrão de ramificação (Figura 15), dependendo do número de ramos que crescem de cada nó (YANG; HUI, 2010).

\subsubsection{6 \\ Folhas e bainhas}

As folhas crescem nos ramos e têm a função de fazer a fotossíntese da planta. As bainhas, também chamadas de folhas caulinares, são folhas especializadas que nascem em cada nó, cobrindo os internós e protegendo os brotos jovens (YANG; HUI, 2010).

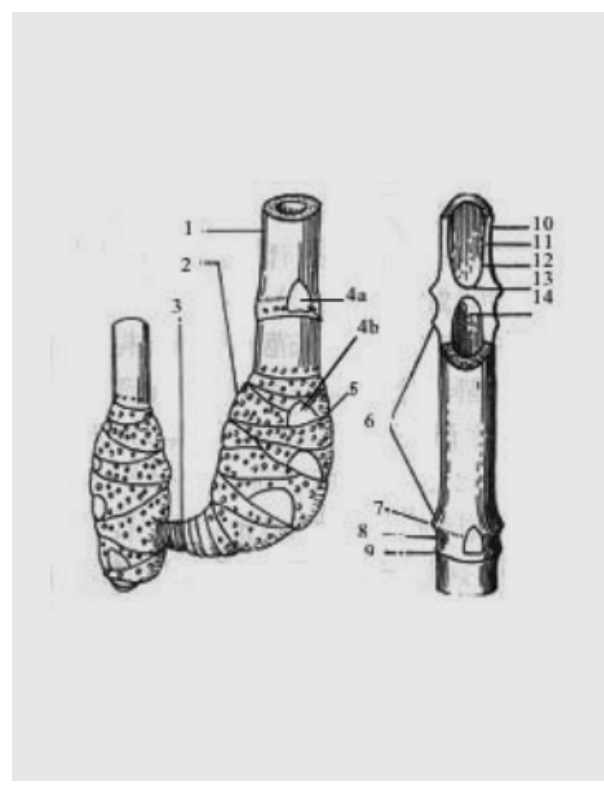

FIGURA 14

Anatomia do colmo: 1. colmo; 2. base do colmo; 3. colo do rizoma; 4. gema de ramo; gema de colmo; 5. gema de raiz; 6 . internó; 7. aresta nodal; 8. intranó; 9. cicatriz da bainha; 10 . córtex; 11. parede do colmo; 12 . superfície da cavidade; 13. diafragma; 14. cavidade. Fonte: YANG; HUI, 2010.

FIGURA 15

Padrões de ramificação. Fonte: YANG; HUI, 2010. 


\subsection{3}

\section{Crescimento do colmo}

O crescimento do colmo de bambu se estabelece em duas fases: o meristema apical, que é responsável pela formação dos tecidos que formam o rizoma, a base do colmo, o rebento do colmo e a ramificação; e o meristema intercolar, responsável pelo crescimento físico dos elementos formados durante o processo anterior.

Uma vez terminada a formação do rizoma, e o rebento do colmo for completado pelo meristema apical, continua o crescimento do colmo de forma telescópica, e cada internó cresce separadamente, começando pelos intrenós da base. O colmo só vai parar de crescer quando o último internó for alongado, deixando aparentes as gemas do nó, que ficam dormentes, de onde podem crescer os ramos, e também onde começa uma nova fase de crescimento vegetativo do bambu.

O crescimento do colmo no primeiro terço do processo é lento, no terço intermediário é muito rápido, e finalmente volta a uma velocidade lenta para finalizar seu alongamento.

Cada novo internó e envolvido por uma folha caulinar fixada ao nó anterior do anel caulinar. Pode-se considerar o ximadamente um ano do nascimento do broto, pois, a partir desse momento, as folhas caulinares (bainhas) secam e caem do colmo. Uma vez completado o crescimento do colmo e a queda das bainhas, tem início o crescimento dos ramos e folhas (HIDALGO-LÓPEZ, 2003).

A brotação dos ramos costuma ocorrer da metade para cima dos colmos; o sistema de crescimento nessa parte da planta não apresenta muitas diferenças morfológicas se comparados os bambus paquimorfos e leptomorfos.

Quando o broto do colmo cresce, já coberto de bainhas, em média entre 30 a $40 \mathrm{~cm}$ do chão, já alcançou seu diâmetro máximo e vai se manter assim até o fim do crescimento. Os colmos de brotações iniciais se desenvolvem melhor e com mais qualidade, ao contrário dos colmos tardios.

Cruz (2002) descreve que o tempo de crescimento vária de acordo com o sistema de propagação e o tamanho da espécie:

Paquimorfo (Figura 16)

Espécies grandes - crescimento em 180 dias;

Espécies pequenas - crescimento em 80 dias;

Leptomorfo (Figura 17)

Espécies grandes - crescimento em 130 dias;
Espécies pequenas - crescimento em 30 dias.

Os dois grandes grupos de bambu apresentam crescimentos distintos e se comportam de forma diferente diante das condições ambientais. Por exemplo, o crescimento dos bambus leptomorfos é favorecido por temperaturas altas; já os bambus paquimorfos, oriundos de climas termicamente regulares, crescem mais durante a noite. 


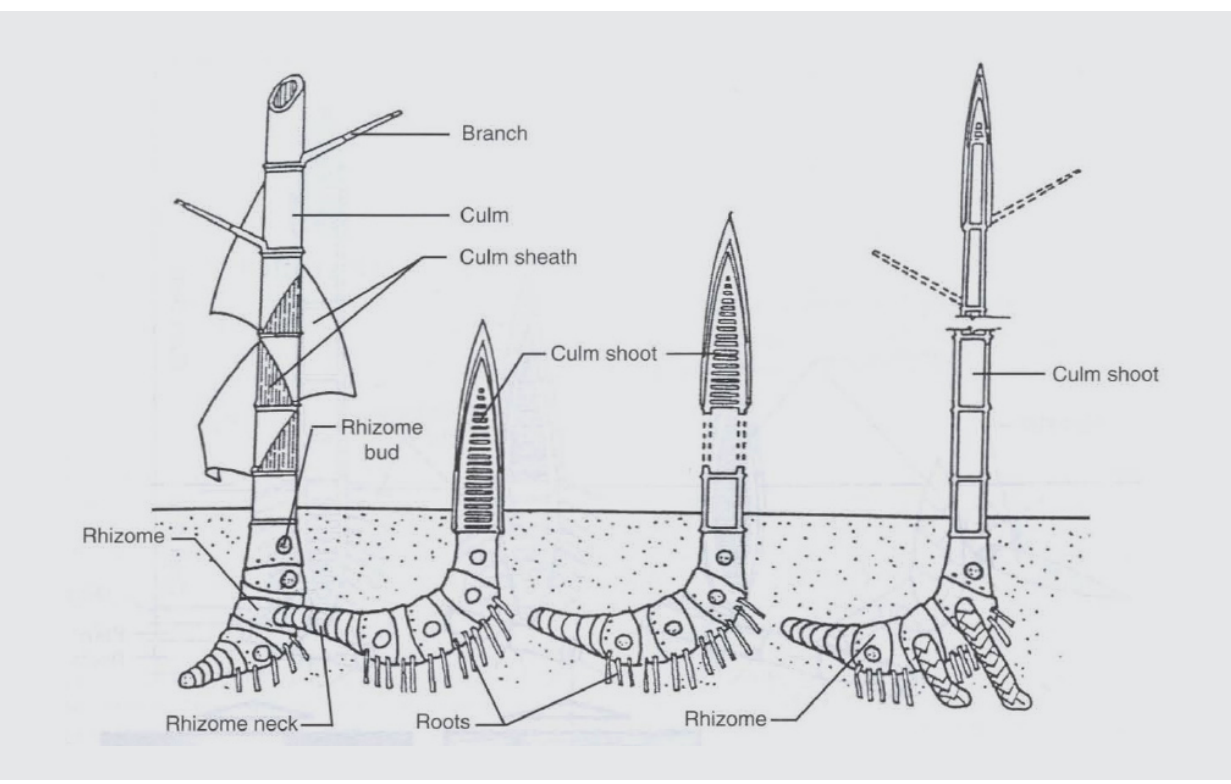

FIGURA 16

Processo de cresci-

mento dos bambus

paquimorfos. Fonte:

HIDALGO-LÓPEZ, 2003.

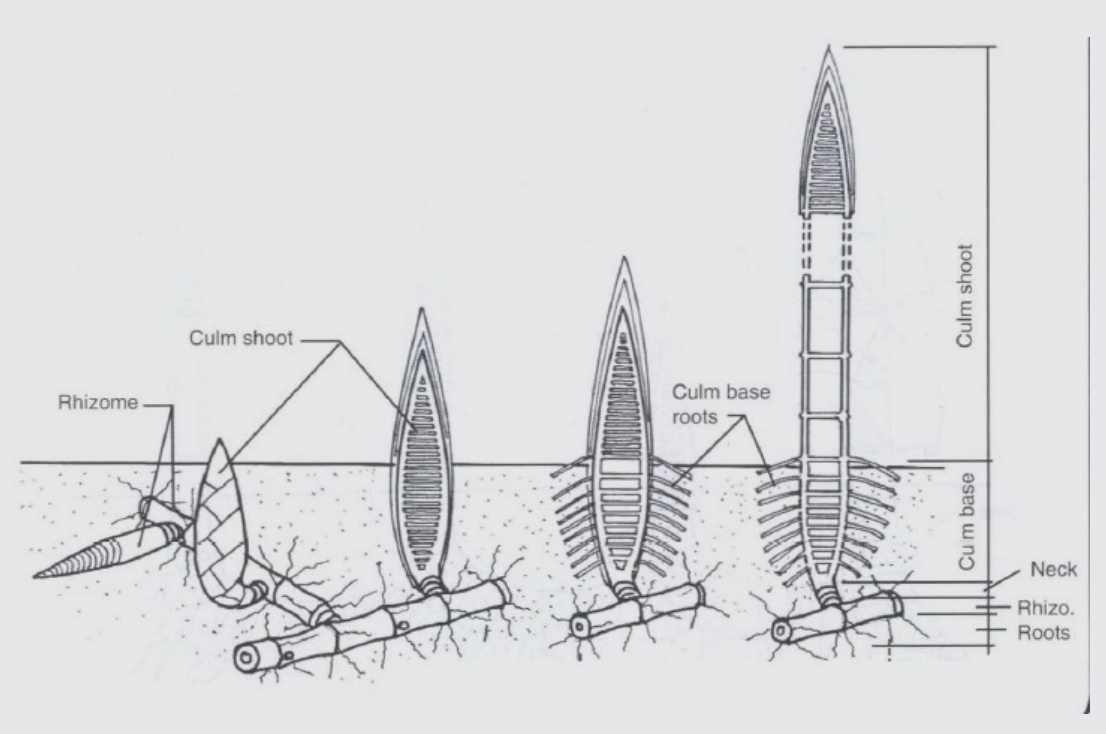

FIGURA 17

Processo de cresci-

mento dos bambus

leptomorfos. Fonte:

HIDALGO-LÓPEZ, 2003. 


\section{Capítulo 2 \\ Caracterização \\ do colmo de bambu}

A aplicação do bambu como material para a construção civil tem ainda um papel secundário no mundo da edificação, principalmente devido ao pouco conhecimento sobre o material em si e seu comportamento submetido a certas condições que podem modificar as caraterísticas das propriedades químicas e físicas do seu estado in natura.

Para poder trabalhar com qualquer material é preciso o conhecer desde a sua composição microscópica até a macroscópica, determinar suas qualidades inerentes e abstrair aqueles elementos comuns que o caracterizam.

Segundo Liese (1998), a estrutura anatômica do colmo de bambu determina suas propriedades. Quando se faz uma análise da composição celular, observa-se uma disposição dos elementos que formam o tecido que tem seu reflexo na formalização geométrica do colmo.

O bambu erroneamente é confundido ou classificado como um mate- rial de construção dentro do grupo das madeiras. Porém, apesar de ser composto quimicamente por substâncias semelhantes, há consideráveis diferenças; sua anatomia, morfologia, crescimeno e, principalmente, seu comportamento mecânico.

Apresenta-se neste capítulo a descrição dos elementos que compõem o tecido celular do bambu, sua distribuição, orientação e localização no plano axial e transversal tanto do internó como do nó, assim como modificações decorrentes de parâmetros externos, como idade, umidade, clima, entre outros. Dessa forma, pretende-se entender posteriormente as propriedades do material e, principalmente, sua resposta a determinadas solicitações mecânicas. Essas respostas determinarão a conveniência ou não do material para sua utilização em estruturas e construções.

É importante destacar que o bambu não é um material homogêneo, e sua composição e 
comportamento variam dependendo de diversos fatores de acordo com a origem do corpo de prova:

1) Amostra proveniente do nó ou internó do colmo;

2) Amostra proveniente da camada interna ou da camada externa da parede do colmo;

3) Amostra proveniente da região basal, intermediária ou apical do colmo;

4) Idade do colmo (jovem até 3 anos, maduro após 3 anos);

Em todos os casos, tamanho, orientação, densidade ou composição das fibras é o fator diferencial nos valores de resistência mecânica.

\section{1}

\section{Microestrutura do bambu}

\subsection{1}

\section{0 tecido celular do colmo}

O bambu é um material compósito vegetal de fibras médias, embora o comprimento das fibras possa variar dependendo da espécie e da origem da amostra no colmo, isto quer dizer que é um material formado na sua estrutura microscópica por várias fases. Segundo Beraldo e Pereira (2008), o bambu é composto em média por $40 \%$ de tecido esclerenquimático, que são as fibras responsáveis pela grande resistência mecânica do material, $50 \%$ formado pelo parênquima, que é o material que forma a matriz - essa fase tem uma resistência mecânica muito mais baixa e age como aglomerante das fibras -, e os $10 \%$ restantes são formados pelos tecidos condutores responsáveis pelo fluxo de nutrientes e água ao longo do colmo. Essas proporções são apenas orientadoras, pois cada espécie tem suas próprias caraterísticas e determinadas concentrações celulares.

A diferença entre as várias espécies de bambu é, em grande medida, devida à espessura da parede do colmo e à tipologia formal dos feixes vasculares.

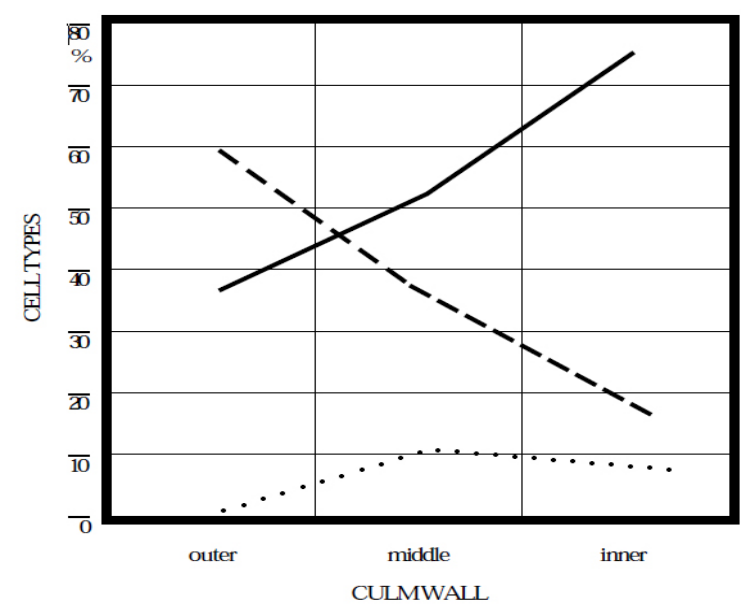

GRÁFICO 1

Concentração de dos tecidos na parede do colmo. Fonte: LIESE,1998. 
O tipo e a concentração das células no colmo de bambu variam segundo a distância relativa ao internó, a altura absoluta no colmo e a posição radial na seção da parede.

A concentração de fibras aumenta no colmo de dentro para fora, e a concentração de parênquima, ao mesmo tempo, diminui nesse mesmo sentido. Os feixes vasculares aumentam de tamanho de fora para dentro do colmo.

Para o estudo das concentrações celulares, adota-se convencionalmente a divisão concêntrica da seção transversal do colmo e se mensuram as porcentagens de concentração em cada um dos três anéis (Gráfico 1).

No sentido axial, o bambu não é uniformemente distribuído na sua concentração dos tecidos, as fibras aumentam com a altura, assim como os tecidos vasculares. Inversamente, o parênquima diminui de acordo com o incremento da altura da amostra analisada. Embora os tecidos condutores e os feixes de fibras também aumentem em quantidade, o seu tamanho se vê reduzido devido ao adensamento de feixes vasculares (conjunto formado por tecido vascular e tecido esclerenquimático) (Gráfico 2).

A concentração das fibras determina a resistência mecânica do nas camadas externas tornam essas partes mais resistentes, assim como a concentração maior de fibras no topo do colmo, fazendo desses segmentos os mais aptos para serem submetidos a esforços mecânicos.

\subsubsection{1 \\ Parênquima}

O parênquima, tecido que forma a matriz do bambu, envolve os feixes vasculares, aglomera as fibras e dá coesão à parede do colmo. As células de parênquima têm um formato prismático aparentemente hexagonal, quando observada microscopicamente a seção transversal do bambu. A largura das células aumenta de fora para dentro do colmo, mas tem diminuido seu tamanho quando estão próximas ao anel medular da cavidade (Figura 1).

No tecido parenquimático armazena-se o amido e também é onde se produz o acúmulo de água no colmo. O maior conteúdo de amido se concentra nos nós e no diafragma; por sua vez, no parênquima do córtex é onde onde ocorre sua menor abundância.

Da quantidade de amido depende o crescimento do colmo e seu rápido desenvolvimento, contudo, quanto maior seja o conteúdo, mais suscetí- vel será o material a ser atacado por organismos xilófagos. Muitos tratamentos preservativos visam remover o amido do colmo e substitui-lo nas células de parênquima por substâncias tóxicas a essas pragas.

A diferença de concentração do amido determina por onde a deterioração do material ocorrerá: se de dentro para fora ou na que é, sem dúvida, a região mais suscetível - a área do corte do colmo. Sem uma falha no córtex, dificilmente o bambu vai ser deteriorado por insetos ou por fungos.

\subsubsection{2 \\ Vasos condutores}

Os vasos condutores são aqueles tecidos do bambu que têm a função de transportar água, minerais e nutrientes ao longo do colmo. Geralmente, estão orientados axialmente, no entanto, nos nós podem adotar outras configurações mais desordenadas. Há três tipos de vasos, segundo a função desempenhada e o tempo de funcionamento durante o crescimento da planta.

O protoxilema é um tecido condutor que transporta água no estágio inicial do crescimento. O metaxilema é um vaso duplo que tem a função de transportar água ao longo do colmo 
durante sua vida. O tamanho deste determina a capacidade do bambu de conter água, de absorvê-la, mas também de absorver e distribuir substâncias para tratamentos preservativos ao longo do colmo. O floema é o conjunto de tecidos condutores que tem a função de transporte da seiva ao longo do colmo.

Segundo Pereira e Beraldo (2008), os vasos condutores constituem os principais vazios existentes no tecido e, portanto, são as regiões de menor resistência mecânica do colmo, agindo como ponto inicial de fratura em caso de tensões acima dos estados limites.

\subsubsection{3}

Fibras

As fibras constituem o tecido esclerenquimático. Formam agrupações dispostas como bainhas ao redor dos vasos condutores.

As fibras são delgadas e alongadas, sua resistência mecânica é diretamente proporcional ao seu comprimento, e este depende da posição relativa no colmo; logo cada parte do colmo tem uma resistência mecânica determinada pela concentração, posição e tamanho das fibras.

As fibras mais curtas estão localizadas, a princípio, perto dos nós, e as

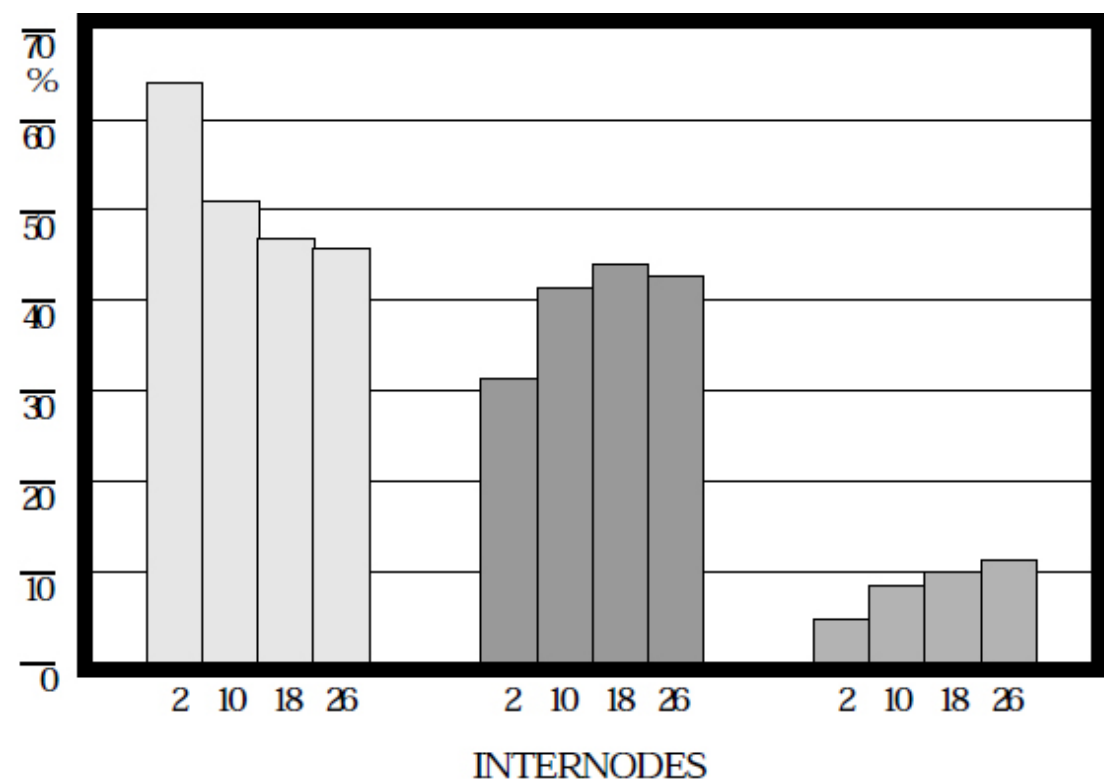

GRÁFICO 1

Porcentagem do tipo de célula em relação à altura do colmo. Fonte: LIESE, 1998.
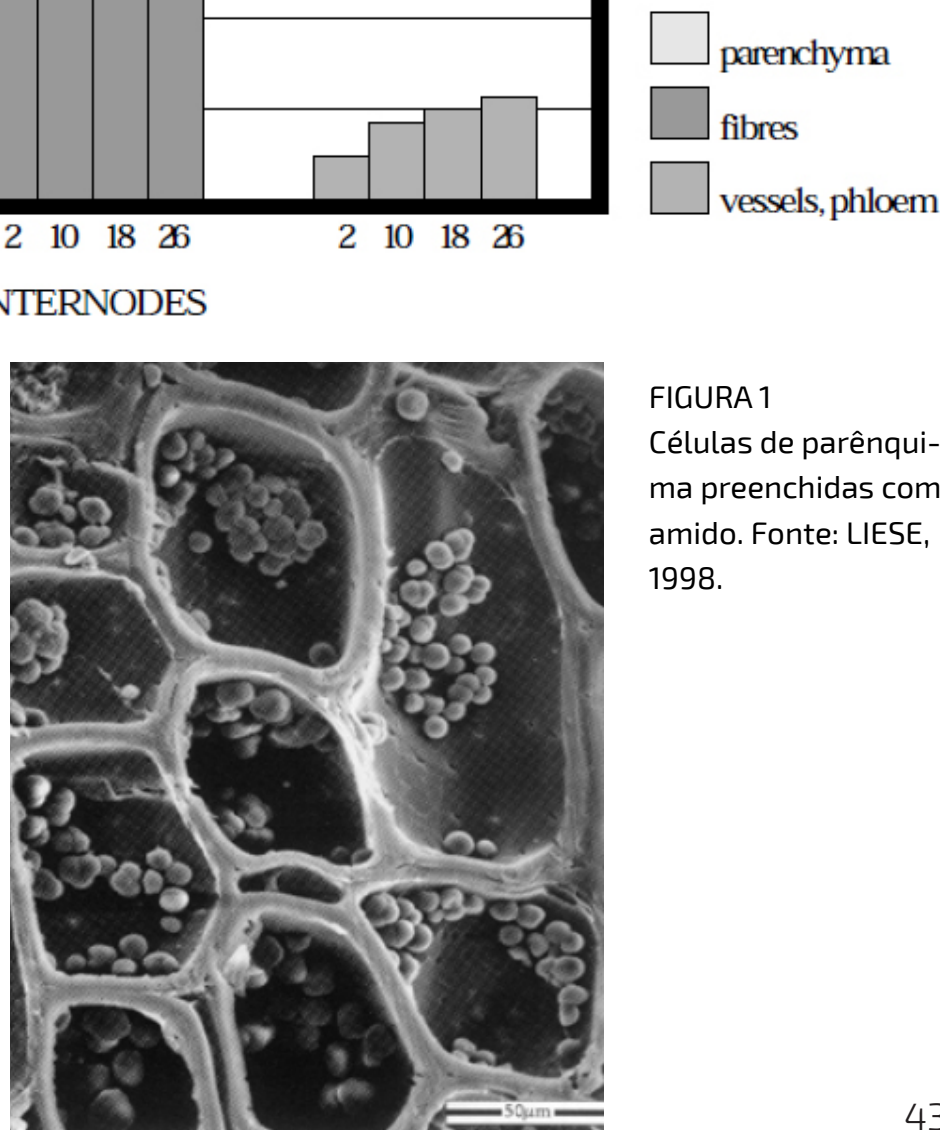

FIGURA 1

Células de parênquima preenchidas com amido. Fonte: LIESE, 1998. 
fibras mais longas se encontram no meio do internó (Figura 2). Em relação à posição tangencial na seção, as fibras mais longas se situam no terço intermediário da parede do colmo, e as mais curtas, no terço interno do colmo (Figura 3). Também em relação à posição na altura absoluta do colmo, as fibras do terço apical e intermediário do colmo de bambu têm comprimentos maiores do que as fibras do terço basal, porém é neste terço onde as fibras tem uma espessura maior.

2.1.7.4

Feixes vasculares

Os feixes vasculares são conjuntos de tecidos formados por vasos condutores (dois metaxilemas, um floema e um protoxilema), bainhas fibrosas (formadas por tecido esclerenquimático que envolvem e, de certa forma, protegem os vasos condutores) e finalmente uma reduzida porcentagem de tecido parenquimático que age como aglomerante dos distintos elementos que compõem o conjunto. Existem, em geral, quatro feixes de fibras em cada feixe vascular, um para cada tipo de condutor (Figura 4).

A aparência do bambu na sua te das suas propriedades mecânicas, depende basicamente da concentração, tamanho e forma dos feixes vasculares. Segundo Liese (1985), há quatro arranjos tipológicos de feixes vasculares distintos: tipos 1, 2, 3 e 4 .

Sob o ponto de vista de resistência mecânica, os bambus com feixes vasculares do tipo 3 e 4 (Figura 5) são mais resistentes do que os bambus com feixes vasculares do tipo 1 e 2 (Figura 6).

\subsection{2}

\section{Estrutura do internó}

2.1.2.1

Camada externa

A camada mais externa do colmo é chamada córtex, e sua função é a proteção do tecido em relação a agentes externos, principalmente a água.

Dentro do córtex existem vários níveis concêntricos, com diferentes composições e propriedades. $\mathrm{O}$ nível mais externo é formado pela epiderme, a camada que tem contato com a intempérie e que confere ao bambu seu aspecto, coloração e textura. Segundo Liese (1998), é formado por células axialmente alongadas, células curtas de cortiça e de sílica, além de estômatos (conjuntos de cé- lulas que fazem a conexão da atmosfera com o interior da planta).

As células externas contêm um alto teor de sílica (dióxido de silício), que é o responsável pela solidez e dureza da camada externa do bambu, mas, em contrapartida, também é responsável pela mínima aderência a aglomerantes.

No bambu natural existe uma fina película de cera que também, de certa forma, ajuda a mantê-lo protegido da água atmosférica, impossibilitando o ganho lateral de água e agindo como mecanismo natural de preservação.

Sob a epiderme se encontra a hipoderme, que é formada por várias camadas de células esclerenquimáticas de parede grossa e muito comprimidas no sentido tangencial, quase sem feixes vasculares nem parênquima.

Seguindo de fora para dentro, a concentração das células esclerenquimáticas isoladas vai diminuindo, os feixes vasculares vão se formando, e a concentração de tecido parenquimático vai aumentando.

\subsubsection{2}

Camada interna

Na camada mais interna da parede do colmo de bambu, dentro da cavidade, se forma o que Liese (1998) nomeia anel medular (em tradução livre), 
que consiste em camadas de células de parênquima lignificadas, mas sem tecido vascular.

\subsubsection{3}

Parede do colmo

O colmo é uma estrutura natural roliça que se caracteriza por uma sequência de interrupções chamadas nós. Cada um dos segmentos entre os nós é chamado de internós. As células que formam esse vegetal estão orientadas paralelas ao eixo longitudinal do colmo, com exceção dos nós, nos quais o tecido celular tem uma disposição mais complexa. Essa disposição axial determina que nos internós e, portanto, na maior parte do colmo, não ocorram elementos anatômicos radiais, consequentemente a circulação de nutrientes e de água, seu crescimento e a resistência mecânica são sempre limitados a uma direção. Trata-se de uma planta em que os sentidos tangencial e radial têm uma relevância secundária.

O vazio interno delimitado por dois diafragmas e a parede do colmo do internó chama-se cavidade. Apesar de não ser frequente, algumas espécies de bambu são completamente sólidas e sem cavidade.
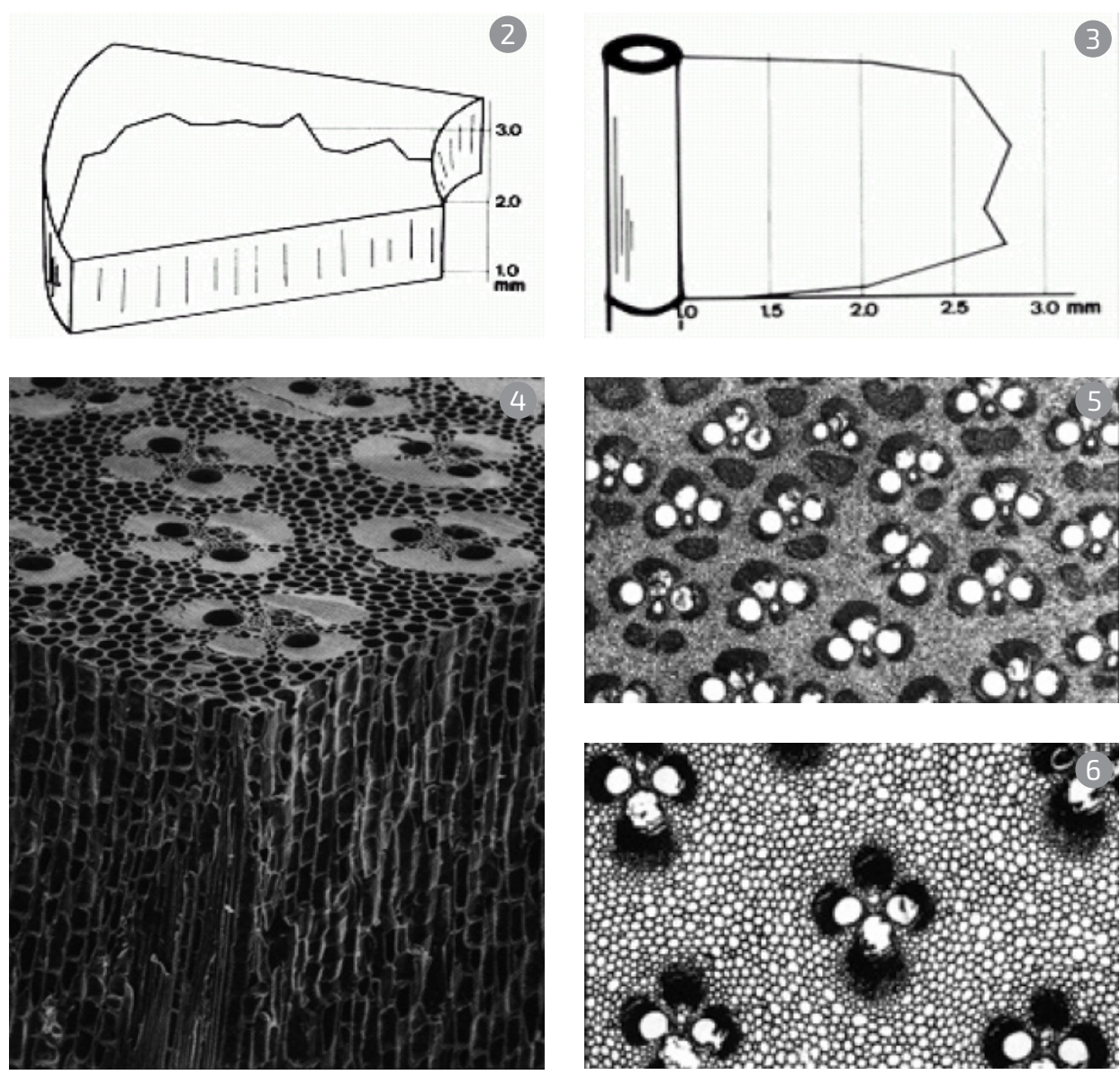

FIGURA 2

Comprimento das fibras na parede do colmo. Fonte: LIESE, 1998.

FIGURA 3

Comprimento das fibras relativas à posição do internó. Fonte: LIESE, 1998

FIGURA 4

Imagem

tridimensional dos

feixes vasculares

envolvidos no tecido parenquimático.

Fonte: LIESE, 1998.

FIGURA 5

Feixes vasculares tipo 3 de uma Oxytenanthera albociliata. Fonte: LIESE, 1998.

FIGURA 6

Feixes vasculares tipo 1 de uma Phyllostachys edulis. Fonte: LIESE, 1998. 
$\mathrm{Na}$ imagem a olho nu de um corte transversal do colmo (Figura 7), pode-se identificar os elementos que o compõem. Uma série de pontos escuros vão se adensando e diminuindo na medida em que se situam mais perto da camada externa. Esses pontos são os feixes vasculares, isto é, conjuntos de tecidos diferentes que formam o elemento resistente do compósito; o tecido esclerenquimático, que forma as fibras do bambu, e dá a cor caraterística aos feixes. $\mathrm{O}$ elemento mais claro que os envolve é o parênquima, que garante a coesão da estrutura da planta, mas que, em nenhum caso, as ótimas propriedades de resistência mecânica são dadas pela sua presença.

Segundo Cusack (1997, apud Liese, 1998), sob um ponto de vista anatômico, os bambus entouceirantes são mais resistentes do que os bambus alastrantes, em função do tipo de arranjo formado pelos feixes de fibras ao redor dos vasos condutores.

\subsection{3}

\section{Estrutura do nó}

O nó é um elemento de grande importância no bambu, não só por lhe conferir um aspecto visual muito caraterístico, mas pelas funções que que toma no comportamento mecânico do colmo. Forma a única situação no colmo em que há uma conexão vascular que foge da disposição axial da maioria dos tecidos celulares. Na região do nó, o transporte de seiva, minerais e água se dá radialmente ou até mesmo tangencialmente.

As caraterísticas morfológicas do nó são dadas pelo diafragma - que pode ser reto, côncavo ou convexo - e pelo intranó, formado pela cicatriz da bainha e da aresta nodal, protuberâncias do nó, que quase não têm significância além do papel desempenhado no crescimento, e por serem pontos fracos, é onde a camada superficial de sílica se interrompe e o colmo é mais indefeso. Por outro lado, o diafragma estrutura o colmo, dá-lhe rigidez e, apesar de sua microestrutura ser formada maioritariamente por células curtas de parênquima lignificado, agrega certa resistência mecânica a esforços perpendiculares. A orientação irregular das fibras, assim como o menor comprimento, prejudica o desempenho em esforços axiais, sendo o ponto de fratura quando submetido a tensões últimas (Gráfico 3).

Nos nós, a estrutura graduada do internó desaparece, dando lugar a um arranjo diferente, mais caótico das fibras e dos vasos condutores (Figura 8), pois os tecidos devem mudar a orientação, que em geral é axial. Os feixes vasculares perdem a morfologia caraterística e se transformam em uma amálgama de vários tecidos sem uma ordem aparente.

\section{2}

\section{Macroestrutura do bambu}

\section{2 .1}

Caraterização geométrica

A geometria do colmo de bambu é basicamente definida por quatro parâmetros: a altura, o diâmetro, a espessura da parede e a distância entre nós. A altura é diferente em cada colmo, mas em cada colmo os outros três parâmetros variam muito dependendo da altura relativa onde se encontrem. A inércia do colmo é diretamente proporcional ao diâmetro do colmo, a espessura da parede do colmo é diretamente proporcional à inércia do colmo e à resistência mecânica do elemento estrutural, a distribuição de nós ao longo do colmo influi tanto positivamente como negativamente na resistência do colmo de acordo com a tensão aplicada e a sua direção.

Como se demonstra no artigo "Propriedades geométricas e mecânicas de colmos dos bambus para aplicação em construções", de 2003, escrito a partir dos estudos realizados 

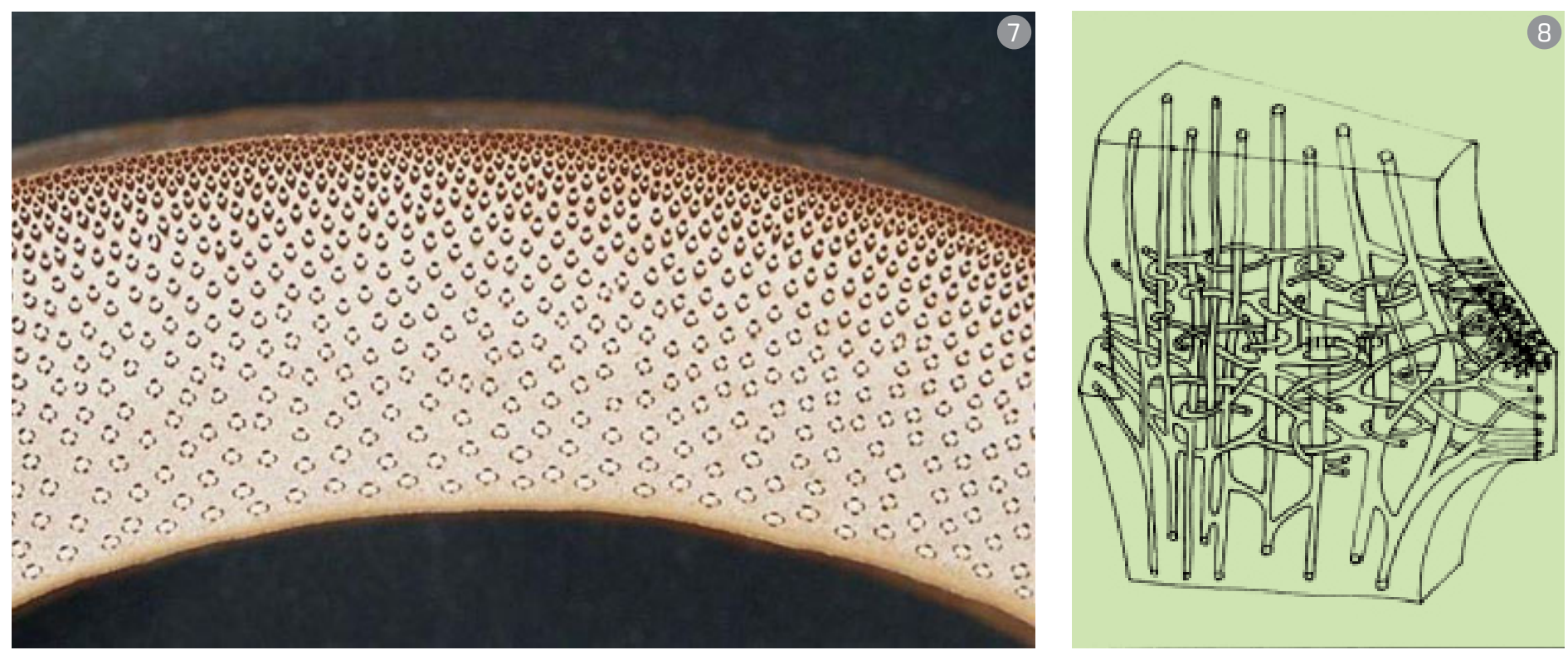

FIGURA 7

Vista da secção

transversal da

parede do colmo da espécie mossô. Disponível em: <https:// www.guaduabamboo.com>. Acesso em mar. 2017.

\section{FIGURA 8}

Estrutura dos vasos no nó. Fonte: LIESE 1998.

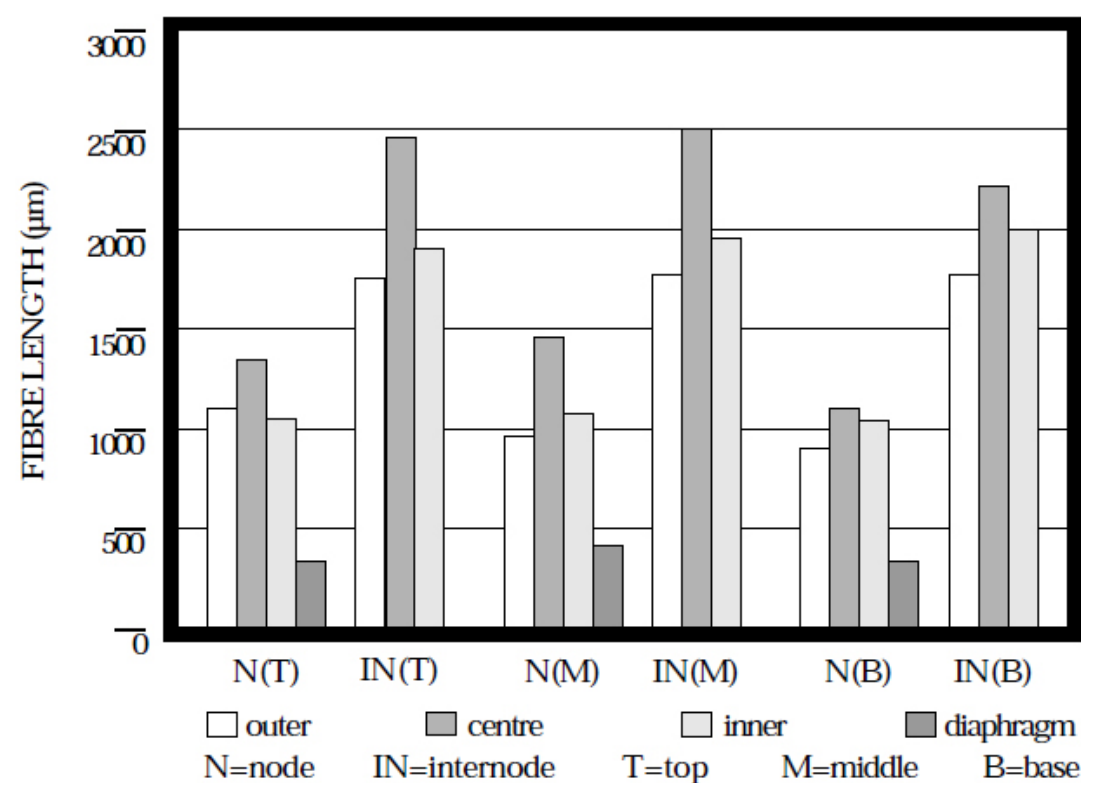

GRÁFICO 3

Comprimento das fibras, segundo altura do colmo e no nó. Fonte: LIESE, 1998. 
por Ghavami e Marinho, o bambu não é um cilindro, apesar de ter essa aparência, tende a diminuir o diâmetro no topo do colmo, tendo um formato levemente cônico. A espessura da parede também tende a diminuir da base para o topo. A distância entre nós tende a ser maior no meio do colmo, e menor na base e no topo. Essas tendências geométricas são constantes na anatomia de várias espécies de bambu, principalmente aquelas com potencial para serem aplicadas na construção civil, mas todas apresentam diferenças entre si.

2.2.1.1

Comprimento internodal

A existência de nós supõem descontinuidades no colmo que, em algumas solicitações mecânicas, implicam perda da resistência.

Em geral, os bambus têm internós mais curtos na base do colmo; no meio do colmo os internós são mais compridos e no topo são curtos novamente (Gráfico 4).

Algumas espécies têm uma variabilidade muito menor nos comprimentos dos internós ao longo do colmo (G. angustifolia), isso quer dizer que podem ser um pouco menos resistentes em alguns esforços, mas os torna altamente adequados, pois facilidade na implantação durante a construção e um comportamento sob esforços, mais previsível.

\subsubsection{2 \\ Diâmetro externo do bambu}

O diâmetro externo do bambu não é constante, vai diminuindo da base para o topo do colmo. A excentricidade cônica é uma das questões abordadas em várias normas, estabelecendo alguns limites na proporção com relação ao comprimento. É necessário que a variação do diâmetro na base com relação ao diâmetro do topo seja mínima e, por outro lado, é interessante que o diâmetro, mesmo que esteja decrescendo, o faça numa sequência regular. Algumas espécies até têm diâmetros constantes na base do colmo, como a G. angustifolia (Gráfico 5).

\subsubsection{3 \\ Espessura da parede}

A espessura da parede determina muitas das propriedades mecânicas do bambu. Quanto mais espessura, mais massa; quanto mais massa, mais fibras; e quanto mais fibras, maior resistência mecânica terá o bambu. Em geral, a espessura é muito grande na base do colmo, mas se mantém bastante regular no terço intermediário e apical (Gráfico 6).
2.2.7.4

Altura do colmo

O comprimento do colmo é importante para obter o máximo rendimento do material. Um colmo maior quer dizer que suporta ao longo do seu comprimento tensões muito maiores, decorrentes das cargas horizontais causadas pelo vento, portanto, aqueles bambus mais compridos terão uma resistência a flexão muito maior do que os mais curtos.

\subsection{2}

\section{Propriedades químicas}

O bambu é composto principalmente por celulose (55\%) e lignina (25\%), além de outros componentes encontrados em quantidade quase residual, como extrativos (amido) e componentes inorgânicos (cinzas) (PEREIRA; BERALDO, 2008). As proporções de cada componente variam entre as espécies de bambu. Ao longo da sua vida e crescimento, as proporções também vão mudando, pelo processo de lignificação dos tecidos. Durante o crescimento do bambu, esse processo de lignificação vai da base do colmo para o topo. As paredes do colmo são lignificadas de dentro para fora. A lignina é a responsável pelo processo de 


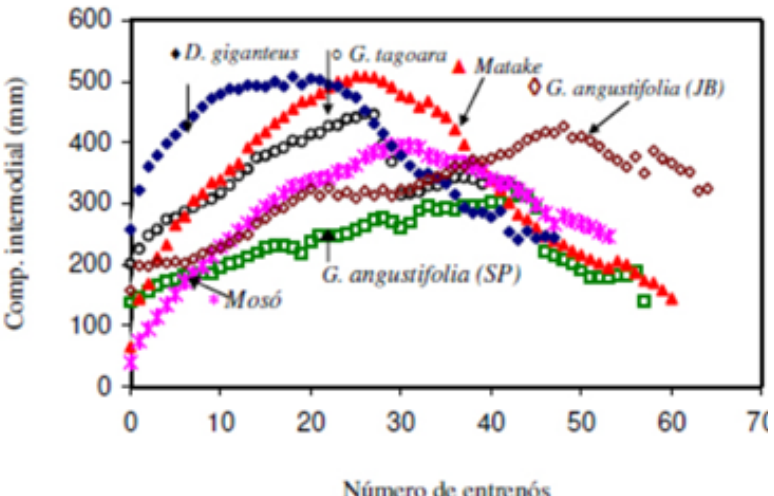

GRÁFICO 4

Comprimento internodal em função do número de internós ao longo do colmo de bambu. Fonte: GHAVAMI; MARINHO, 2003.

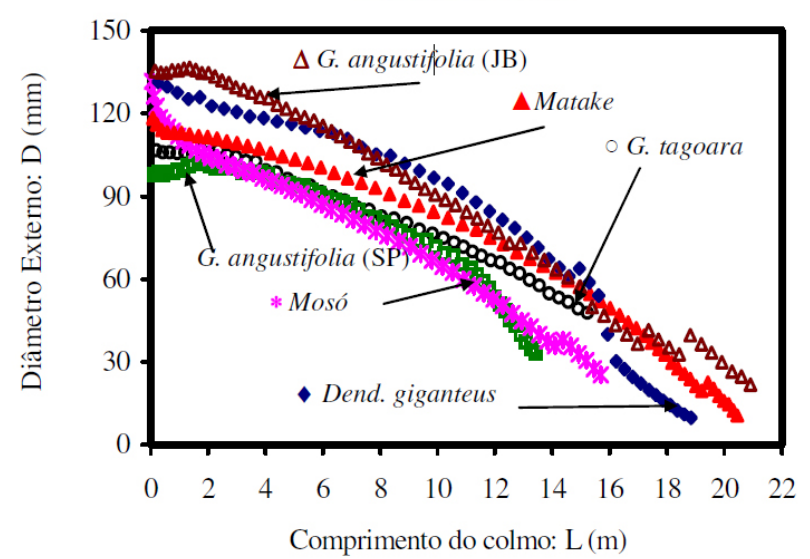

GRÁFICO 5

Diâmetro externo em função do comprimento do colmo de bambu. Fonte: GHAVAMI; MARINHO, 2003.

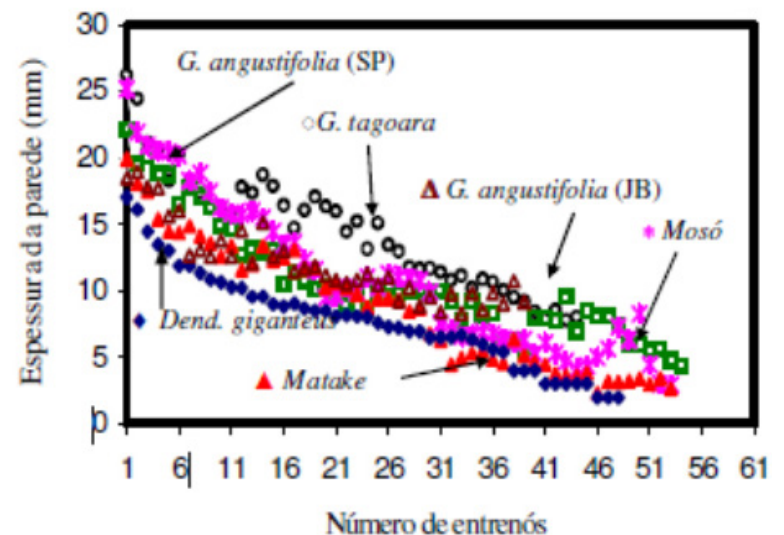

\section{GRÁFICO 6}

Espessura da parede em função do número de entrenós ao longo do colmo de bambu. Fonte: GHAVAMI; MARINHO, 2003. 
enrijecimento das paredes celulares, dando-lhes maior resistência e impermeabilidade (FENGEL; WEGENER apud BILESKY, 2014).

Esse processo de lignificação é o que proporciona que os colmos maduros tenham um desempenho mecânico tão elevado comparado com os colmos jovens, que apresentam menor resistência mecânica a esforços.

\subsection{3}

Propriedades físicas

As propriedades físicas do bambu são determinadas pela distribuição, posição e quantidade das diferentes tipologias celulares nos tecidos, e também pela quantidade de água acumulada nesses tecidos.

2.2.3.1

Massa específica

Define a massa do material por unidade de volume, atributo também conhecido como densidade. A massa específica relativa é a densidade do bambu em relação à densidade da água.

Hidalgo-López (2003) determina que a massa específica do bambu varia entre 0,5 a $0,9 \mathrm{~g} / \mathrm{cm}^{3}$, dependendo da espécie de bambu, da posição de origem de rizoma. Já os estudos de Du e Zhang (1998, apud HIDALGO-LÓPEZ, 2003)

revelam que os bambus entouceirantes são mais densos que os alastrantes.

A massa específica do bambu é maior na parte externa da parede do colmo e diminui na parte interna, assim como também diminui do topo do colmo para a base. Isso é devido à massa específica das células esclerenquimáticas, que é maior do que das células parenquimáticas, e a concentração delas na camada externa, assim como na parte apical do colmo, é consideravelmente maior.

A massa específica dos nós também é menor do que nos internós por conta da menor quantidade de fibras (tecido esclerenquimático). Segundo Hidalgo-López (2003), existe uma forte relação entre massa específica e resistência mecânica do bambu, assim o terço apical de um colmo terá mais resistência à compressão que as demais regiões.

\subsubsection{2 \\ Umidade}

As propriedades mecânicas do bambu são modificadas de acordo com o teor de umidade nos tecidos. O teor de umidade (TU) é um parâmetro do material que determina o peso de água contido nas paredes e células do colmo de bambu, expressado em uma porcentagem em relação ao seu peso totalmente seco.

O teor de umidade no bambu varia muito segundo a espécie, sendo que, dentro de uma mesma moita, o teor pode variar dependendo do colmo. Os colmos mais jovens, de até 2 anos, têm maior teor de umidade do que os velhos, e uma quantidade semelhante ao longo do colmo. Por outro lado, os bambus maduros têm uma redução no teor de umidade de baixo para cima do colmo. Já os internós têm um maior de teor de umidade do que os nós.

A resistência mecânica é mais elevada nos colmos secos do que nos úmidos. Segundo Liese (1998), as diferenças de resistência dos colmos quando secos e com TU alto é relativamente pequena na resistência ao fendilhamento e à flexão estática.

O bambu tende a equilibrar o teor de umidade interna com a do ambiente onde se encontra. Se o ambiente for mais úmido que o próprio bambu, este vai absorver água e vai perder água caso o balanço de umidade seja negativo.

O ponto de saturação das fibras (PSF) é o ponto em que a quantidade de água nos vasos condutores é nula, e só resta no bambu a água acumu- 
lada nos outros tecidos. O ponto de saturação das fibras do bambu está situado entre $18 \%$ e $20 \%$ (HIDALGO-LÓPEZ, 2003).

2.2.3.3.

Estabilidade dimensional

O bambu apresenta variações dimensionais quando seu TU cai abaixo do PSF. Essas variações dimensionais ocorrem na direção perpendicular ao eixo das fibras, ou seja, nas direçoes radial e tangencial do colmo. Os colmos imaturos apresentam maiores variações dimensionais do que os maduros.

Segundo Hidalgo-López (2003), quando o teor de umidade do colmo está entre $40 \%$ e $70 \%$, não ocorre contração do colmo, se estabiliza dimensionalmente. $\mathrm{O}$ parênquima apresenta uma variação dimensional muito pequena, a maior contração ocorre nos vasos condutores, que é a parte mais débil do bambu. As variações de umidade, densidade e tensão nas paredes do bambu são responsáveis principalmente pelos comportamentos adversos no material quando é utilizado em obra.

Abaixo do PSF, o bambu tem variações dimensionais irreversíveis e excessivas que podem levar ao colapso dos colmos. Abaixo do PSF, o comportamento é controlado e semelhante ao da madeira.

No momento em que o bambu é abatido, tem início a fase de secagem até atingir-se a umidade de equilíbrio com o ambiente (UEA). Uma perda acelerada da umidade pode levar ao fendilhamento da superfície externa, devido a tensões de tração internas bruscas que as células de parênquima e as células dos vasos condutores são incapazes de resistir.

Variações dimensionais estão relacionadas ao estágio de maturação da fibra e à densidade dos feixes vasculares. Os colmos mais maduros são mais estáveis do que os jovens. Nos nós há uma massa específica é mais elevada, portanto, a variação dimensional é menor, e a resistência à tração axial também é menor, já que as fibras nesse ponto são mais curtas e este comprimento tem uma relação direta com o módulo de elasticidade.

\subsection{4}

Propriedades mecânicas

As propriedades mecânicas dos bambus estão diretamente relacionadas à sua estrutura anatômica. Essa estrutura é definida de forma abstrata pela massa específica do material, que, por sua vez, é deter- minada pela concentração de fibras (LIESE, 1998). Qualidade, quantidade, diâmetro, comprimento e espessura das paredes das fibras são os parâmetros que definirão muitos aspectos do comportamento mecânico do bambu.

A variedade desses parâmetros entre as espécies implica a impossibilidade de extrapolar os testes de resistência mecânica de uma espécie para outra. Cada uma precisa ser estudada com uma mesma metodologia, mas de acordo com suas especificidades.

O bambu apresenta um desempenho mecânico ótimo, com valores altíssimos de resistência a determinadas tensões quando aplicadas na direção longitudinal do colmo, que, relacionado à sua reduzida massa específica, o faz se aproximar dos valores de resistência do aço. Porém, apesar de as fibras do bambu estarem alinhadas, não estão uniformemente distribuídas na matriz parenquimática, fazendo com que as propriedades mecânicas variem ao longo da espessura do colmo.

Pode-se considerar o bambu como um material ortotrópico, pois ele tem um comportamento mecânico no eixo da direção das fibras e outro comportamento no plano perpendicular ao eixo das fibras. $\mathrm{O}$ bambu tem uma resposta diferente 


\begin{tabular}{|c|c|c|c|c|}
\hline \multirow{3}{*}{$\begin{array}{l}\text { TABELA } 1 \\
\text { Propriedades mecâ- } \\
\text { nicas dos internós do } \\
\text { bambu com e sem nó } \\
\text { (P. pubescens). }\end{array}$} & Tensão & $\begin{array}{l}\text { Sem nó } \\
\text { (MPa) }\end{array}$ & $\begin{array}{l}\text { Com nó } \\
\text { (MPa) }\end{array}$ & $\begin{array}{l}\text { Mudança } \\
\text { devido ao nó }\end{array}$ \\
\hline & Tração (Longitudinal) & 263,4 & 212,8 & $-19,2 \%$ \\
\hline & Flexão (Longitudinal) & 136,6 & 131,3 & $-3,9 \%$ \\
\hline \multirow{4}{*}{$\begin{array}{l}\text { Fonte: HIDALGO-LÓ- } \\
\text { PEZ (2003) apud ZEN; } \\
\text { LI; ZHOU (1992) e } \\
\text { ZHOU (1994). }\end{array}$} & Compressão (Longitudinal) & 62,6 & 58,6 & $-6,4 \%$ \\
\hline & Cisalhamento (Longitudinal) & 13,1 & 12,2 & $-6,9 \%$ \\
\hline & Tração (Transversal) & 3,0 & 3,6 & $+20 \%$ \\
\hline & Fendilhamento (Transversal) & 0,6 & 0,8 & $+33,3 \%$ \\
\hline & Tenacidade (L) $\left(\mathrm{kJ} / \mathrm{m}^{2}\right)$ & 89,6 & 77,7 & $-13,5 \%$ \\
\hline
\end{tabular}

dependendo se a tensão aplicada for na direção longitudinal do colmo, ou se for em qualquer das direções do plano transversal, devido a que apresenta uma seção quase circular para algumas espécies.

Torna-se necessário serem desenvolvidos estudos e análises estatísticas das propriedades físico-mecânicas das espécies adequadas para construção civil, a fim de estabelecer os critérios de cálculo do dimensionamento dos elementos estruturais e, assim, estender o conhecimento para serem aplicados por arquitetos e engenheiros nas edificações.

Como é possível observar na Tabela 1, embora seja um estudo das propriedades mecânicas de uma única espécie de bambu, o comportamento do material quando submetido a diferentes tensões é muito caraterístico e se repete não nos mesmos valores, mas na mesma proporção em outras espécies utilizadas em construções.

Apresentam-se a seguir avaliações qualitativas da resistência mecânica do bambu, feitas a partir de diversos estudos desenvolvidos no Brasil e na Colômbia, que procuraram determinar quantitativamente o comportamento do bambu segundo o sentido, a direção das forças aplicadas e a espécie. 
Cada espécie de bambu tem uma resistência diferente, e dentro da mesma espécie, dependendo de fatores ambientais de crescimento, pode haver diferenças, mas, grosso modo, os bambus lenhosos têm comportamentos semelhantes, só variando a magnitude das respostas mecânicas. Para determinar as propriedades mecânicas do bambu com valores padronizados internacionalmente, foi criada a norma internacional ISO 22157-1:2004 Bamboo - Determination of physical and mechanical properties. Essa norma estabelece os requerimentos para avaliação das caraterísticas físicas e mecânicas do bambu. A norma técnica colombiana NTC5525 é uma adaptação da norma ISO para estabelecer os métodos de ensaio que determinam as propriedades físicas e mecânicas somente da espécie G. angustifólia. Todavia, existem vários estudos realizados por organismos e instituições que realizam pesquisas com metodologias muito díspares, alguns discriminam quando a amostra tem nó ou não, discriminam a idade do colmo, o teor de umidade, os elementos, mas precisam unificar metodologias e critérios para poder fazer análises comparativas mais precisas.
2.2.4.1

Tração axial

O bambu apresenta um desempenho estrutural excelente quando é submetido a esforços de tração paralela às fibras (Figura 9), mas isso ocorre sempre a partir de um ponto de vista teórico. Os testes de tração axial do bambu geram certa controvérsia, já que, para obter resultados confiáveis, utilizam-se corpos de provas extraídos das paredes do colmo, o que dá resultados relativos do seu comportamento quando submetido a esse tipo de tensão. Quando o intuito é controlar e estabelecer valores de resistência mecânica do colmo inteiro, para entender o comportamento numa escala macroestrutural, as limitações geométricas e mecânicas do bambu roliço não permitem a produção de testes confiáveis. Isso quer dizer que não existe um sistema de fixação do bambu que permita a submissão do colmo aos seus estados limites de tração sem ficarem distorcidos por possíveis deteriorações dos pontos de fixação, como esmagamento ou fendilhamento causados por tensões residuais inerentes à máquina de testes, ou simplesmente por deslizamento por uma deficiente pressão das garras. Esses problemas de fixação ocorrem também em ensaio de corpos de prova menores, em menor grau.
FIGURA 9

Tração axial no colmo. Autor: Joan Font.

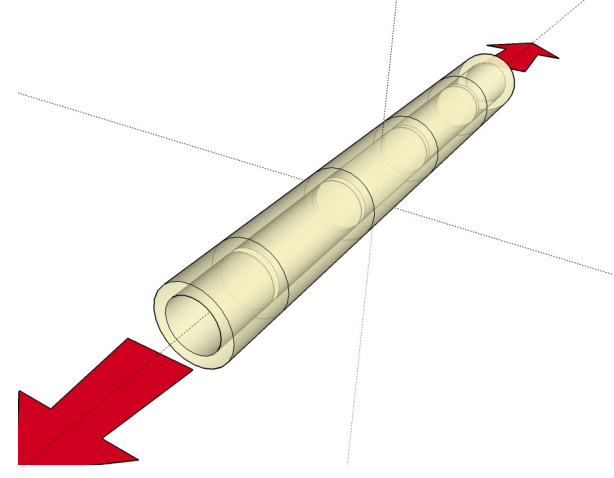


Pode-se observar na Tabela 2, a partir dos resultados de trabalhos de vários pesquisadores com diferentes espécies, que o bambu tem uma grande resistência a tração que vária de entre 66,22 $\mathrm{MPa}$ a $210,4 \mathrm{MPa}$, sendo que a média dos testes aqui descritos de $145 \mathrm{MPa}$. Os módulos de elasticidade (MOE) também estão dentro de uma faixa entre 14,59 GPa e 21,12 $\mathrm{GPa}$. É interessante destacar quatro aspectos da variação dos resultados obtidos que se repetem constantemente em diferentes parâmetros ou espécies do bambu:

1) A resistência mecânica do bambu no internó é maior do que quando o ensaio é realizado com nó.

2) A resistência mecânica da região da base é menor do que na região intermediária e apical. Sendo que na maioria dos casos o terço apical é o mais resistente.

3) A variação tão díspar entre os valores máximos e mínimos. Essa condição é essencial para entender que os bambus dentro da mesma espécie têm crescimentos diferentes, e o crescimento influi nas propriedades. Nos testes feitos por Ghavami e Marinho (2001), comparados com os testes feitos por Pereira (2006) com a espécie $D$. giganteus, mostram valores muito altos mas significativamente testes com $G$. angustifolia realizados por Ghavami (2002) e Ardilla Pinilla (2013), em que os coeficientes de segurança tão altos que se estabelecem para o cálculo de estruturas de bambu.

4) A espécie Phyllostachys aurea mostra alguns valores acima dos demais, mas é uma espécie de pequeno porte, que não produz colmos suficientemente grandes para serem utilizados em estruturas, apesar que, como contraventamentos, teriam um rendimento excelente.

Os estudos realizados por Ardilla (2013) mostram que o TU influi na resistência mecânica do colmo. Nos seus ensaios, os bambus com uma média de 14\% de TU tiveram um 16\% mais de resistência mecânica do que aqueles com TU em média de 51\%.

\subsubsection{2 \\ Compressão axial}

O bambu mostra um bom desempenho quando submetido à compressão axial (Figura 10), ou seja, paralela às fibras. Para testes de compressão axial, é mais fácil conseguir valores confiáveis do corpo de provas do colmo inteiro ou de porções dele, pois não precisa de subjeção ou garras que possam distorcer os resultados, assim podem se estabelecer valores mais confiáveis.
O teor de umidade do colmo diminui a resistência mecânica à compressão. A idade do colmo é um fator de influência, colmos jovens resistem menos do que os maduros, tanto pela lignificação das células como pelo alto teor de úmidade nos tecidos.

Existe uma relação direta entre a resistência à compressão e a quantidade de fibras esclerenquimáticas no material, portanto, a área externa da seção do bambu resiste mais. A resistência do bambu é maior no topo do colmo e vai diminuindo em direção à base. Perto dos nós, as fibras são mais curtas e, no meio do internó, mais compridas, pois isso ocorre uma relação direta com o comportamento mecânico do bambu, sendo mais resistente no meio do internó.

Observa-se que, nos testes de compressão axial, a fratura dos corpos de prova se manifesta como uma fenda no sentido axial. O colapso durante esse esforço se produz nas células de parênquima, às vezes por uma tensão residual de cisalhamento paralela às fibras, ou muitas vezes a fratura é devida a microflambagem das fibras do bambu que produzem trações perpendiculares ao eixo do colmo que o parênquima não consegue suportar. Uma vez produzida a primeira rachadura, o bambu inteiro entra em colapso. 


\begin{tabular}{|c|c|c|c|c|c|c|c|c|c|c|c|c|c|}
\hline \multicolumn{2}{|l|}{ Autor } & \multicolumn{2}{|c|}{$\begin{array}{l}\text { Ghavami e } \\
\text { Marinho } \\
\text { (2002) }\end{array}$} & \multicolumn{2}{|c|}{$\begin{array}{l}\text { Ghavami e } \\
\text { Marinho } \\
\text { (2001) }\end{array}$} & \multicolumn{2}{|c|}{$\begin{array}{l}\text { Sanchez } \\
\text { Cruz } \\
(2002)\end{array}$} & \multicolumn{2}{|c|}{$\begin{array}{l}\text { Pereira } \\
(2006)\end{array}$} & \multicolumn{2}{|c|}{$\begin{array}{l}\text { Berndsen } \\
\text { et al. (2014) }\end{array}$} & \multicolumn{2}{|c|}{$\begin{array}{l}\text { Ardila Pinilla } \\
\text { (2013) }\end{array}$} \\
\hline \multicolumn{2}{|l|}{ Espécie } & \multicolumn{2}{|c|}{ G. angustifolia } & \multicolumn{2}{|c|}{ D. Giganteus } & \multicolumn{2}{|c|}{ P. aurea } & \multicolumn{2}{|c|}{ D. Giganteus } & \multicolumn{2}{|c|}{ P. Pubescens } & \multicolumn{2}{|c|}{ G. angustifolic } \\
\hline Parâmetro & Região & $\begin{array}{l}\text { Res. } \sigma_{t} \\
(\mathrm{MPa})\end{array}$ & $\begin{array}{l}\mathrm{MOE} \\
(\mathrm{GPa})\end{array}$ & $\begin{array}{l}\text { Res. } \sigma_{t} \\
(\mathrm{MPa})\end{array}$ & $\begin{array}{l}\mathrm{MOE} \\
(\mathrm{GPa})\end{array}$ & $\begin{array}{l}\text { Res. } \sigma_{t} \\
(\mathrm{MPa})\end{array}$ & $\begin{array}{l}\mathrm{MOE} \\
(\mathrm{GPa})\end{array}$ & $\begin{array}{l}\text { Res. } \sigma_{t} \\
(\mathrm{MPa})^{2}\end{array}$ & $\begin{array}{l}\text { MOE } \\
\text { (GPa) }\end{array}$ & $\begin{array}{l}\text { Res. } \sigma_{t} \\
(\mathrm{MPa})\end{array}$ & $\begin{array}{l}\mathrm{MOE} \\
(\mathrm{GPa})\end{array}$ & $\begin{array}{l}\text { Res. } \sigma_{t} \\
(\mathrm{MPa})^{-}\end{array}$ & $\begin{array}{l}\mathrm{MOE} \\
(\mathrm{GPa})\end{array}$ \\
\hline \multirow[t]{2}{*}{ Base } & Sem nó & 93,38 & 16,25 & 159,3 & 23,1 & 193,1 & 18,4 & 240,1 & 20,1 & \multirow{2}{*}{199.2} & \multirow{2}{*}{7,97} & \multirow{2}{*}{\multicolumn{2}{|c|}{60,53}} \\
\hline & Com nó & 69,88 & 15,70 & 73,1 & 11,7 & 174,7 & 19,0 & 103,3 & 16,9 & & & & \\
\hline \multirow[t]{2}{*}{ Meio } & Sem nó & 95,80 & 18,10 & 224,0 & - & 234,8 & 20,7 & 250,0 & 20,7 & \multirow{2}{*}{221,3} & \multirow{2}{*}{30,50} & \multirow{2}{*}{\multicolumn{2}{|c|}{70,32}} \\
\hline & Com nó & 82,62 & 11,10 & 118,8 & 20,8 & 220,3 & 16,3 & 117,5 & 18,6 & & & & \\
\hline \multirow[t]{2}{*}{ Topo } & Sem nó & 115,84 & 16,36 & 147,1 & - & 272,4 & 23,7 & 246,8 & 20,7 & \multirow{2}{*}{170,9} & \multirow{2}{*}{24,89} & \multirow{2}{*}{71,61} & \multirow{2}{*}{17,29} \\
\hline & Com nó & 64,26 & 8,0 & 116,3 & 18,3 & 167,1 & 15,2 & 114,4 & 19,5 & & & & \\
\hline \multicolumn{2}{|c|}{ Valor médio } & 86,96 & 14,59 & 139,76 & 18,47 & 210,4 & 18,88 & 178,68 & 19,41 & 192,8 & 21,12 & 66,22 & 15,32 \\
\hline
\end{tabular}

TABELA 2

Testes de tração axial (paralela às fibras).

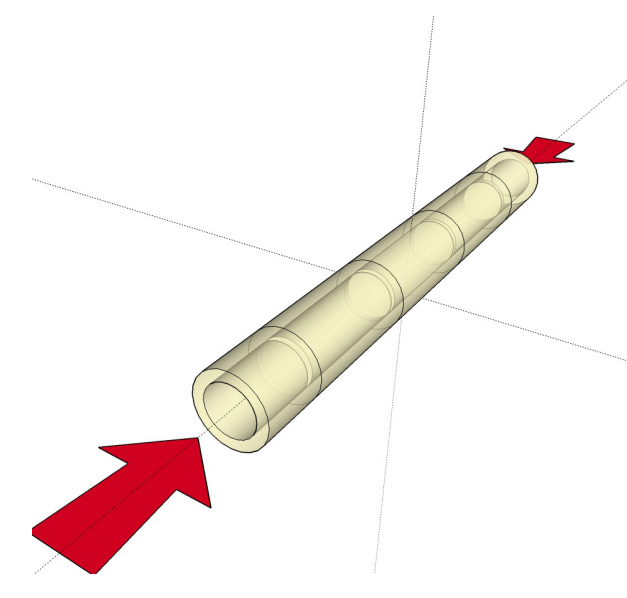

FIGURA 10

Compressão axial no colmo. Autor: Joan

Font. 
Nos dados apresentados na Tabela 3, são observados os seguintes comportamentos:

1) A resistência à compressão axial apresenta valores mais elevados nas amostras sem nó do que com nó;

2) O valor também é mais elevado na parte apical do colmo diminuindo em direção à base;

3) A espécie que apresenta alguns dos melhores resultados é a $D$. giganteus;

4) A resistência à tração paralela âs fibras é sempre superior à compressão axial. No caso da G. angustifolia, analisado por Ardilla Pinilla (2013), o valor de tração paralela às fibras é de 1,5 vez os valores de flexão estática. Mas, no caso do $P$. pubescens analisado por Berndsen et al. (2013), foi de 4,8 vezes maior em tração do que em compressão.

2.2.4.3

Flexão estática

O bambu é, segundo Nogata e Takahashi (1995), um material "inteligente”, e sua geometria foi modificada e evoluida durante toda a sua existência para se adaptar às principais tensões as quais é submetido. Ao ser um cilindro que naturalmente se projeta verticalmente para cima, o colmo de bambu é submetido de forma auto- pois o vento aplica sempre uma carga distribuída aplicada horizontalmente.

$\mathrm{O}$ acúmulo de fibras no córtex e na área externa da seção cilíndrica favorece, dentre outras coisas, a resistência aos esforços de flexão, assim como a sequência de nós colabora nos esforços cortantes transversais ao eixo do colmo do mesmo modo que os estribos fazem nas estruturas de concreto armado (PEREIRA; BERALDO, 2008).

A flexão transversal às fibras não deixa de ser uma tensão combinada de esforços de compressão e tração axial no material, mas, perpendicularmente às fibras, essas tensões compressivas causam tensão elástica lateral, e o parênquima é fraco nessa solicitação. O momento fletor no colmo também produz tensão de cisalhamento. Isso significa que a falha pode ocorre simultaneamente na parte superior do colmo, onde ocorre o máximo esforço de compressão, ou na camada neutra, onde há o maior esforço de cisalhamento (VAESSEN; JANSSEN, 1997).

Como em quase todos os ensaios realizados com bambu, existe certa dificuldade em fazer testes sem distorções devido a modificações geométricas nos tecidos das amostras pelo esmagamento nas fixações, ou nos cutelos, ou por deslizamentos dos apoios.
Os resultados dos ensaios obtidos em corpos de prova extraídos da parede do colmo mostram valores do módulo de ruptura muito altos situados entre os valores de compressão e tração. Quando o teste é realizado com o colmo inteiro (ARDILLA, 2013), os valores diminuem, mas se mantêm razoavelmente altos.

Os testes revelam que o módulo de ruptura (MOR) em amostras com nó é menor do que sem nó, e que a resistência no terço apical é sensivelmente maior do que no resto do colmo.

2.2 .4 .4

Cisalhamento axial (interlaminar)

Diferentemente das madeiras, o bambu não possui fibras dispostas radialmente ou tangencialmente, todas são axiais (com exceção dos nós), o que as mantém juntas é o parênquima, o material matricial do compósito. O parênquima tem uma função aglomerante, mas é pouco resistente quando submetido a esforços, pois colapsa facilmente, e é nessa fase do material que, quando submetido a cortante axial, fratura.

O cisalhamento axial (Figura 12) não é uma tensão aplicada expressamente nos colmos nas estruturas com bambu, porém ocorre como tensão residual quando o bambu é solicitado à 


\begin{tabular}{|c|c|c|c|c|c|c|c|c|c|c|c|c|}
\hline \multicolumn{2}{|l|}{ Autor } & $\begin{array}{l}\text { Ghavami e } \\
\text { Marinho } \\
(2001)\end{array}$ & \multicolumn{2}{|c|}{$\begin{array}{l}\text { Ghavami e } \\
\text { Marinho } \\
(2001)\end{array}$} & \multicolumn{2}{|c|}{$\begin{array}{l}\text { Sanchez } \\
\text { Cruz } \\
(2002)\end{array}$} & \multicolumn{2}{|c|}{$\begin{array}{l}\text { Pereira } \\
(2006)\end{array}$} & \multicolumn{2}{|c|}{$\begin{array}{l}\text { Berndsen et } \\
\text { al. (2013) }\end{array}$} & \multicolumn{2}{|c|}{$\begin{array}{l}\text { Ardila Pinilla } \\
\text { (2013) }\end{array}$} \\
\hline \multicolumn{2}{|l|}{ Espécie } & G. angustifolia & \multicolumn{2}{|c|}{ D. giganteus } & \multicolumn{2}{|c|}{ P. aurea } & \multicolumn{2}{|c|}{ D. giganteus } & \multicolumn{2}{|c|}{ P. pubescens } & \multicolumn{2}{|c|}{ G. angustifolic } \\
\hline Parâmetro & Região & $\begin{array}{ll}\text { Res. } \sigma_{t} & \text { MOE } \\
(\mathrm{MPa}) & (\mathrm{GPa})\end{array}$ & $\begin{array}{l}\text { Res. } \sigma_{t} \\
(\mathrm{MPa})\end{array}$ & $\begin{array}{l}\text { MOE } \\
(G P a)\end{array}$ & $\begin{array}{l}\text { Res.o } \\
\text { (MPa) }\end{array}$ & $\begin{array}{l}\text { MOE } \\
\text { (GPa) }\end{array}$ & $\begin{array}{l}\text { Res. } \sigma_{t} \\
(\mathrm{MPa})\end{array}$ & $\begin{array}{l}\text { MOE } \\
\text { (GPa) }\end{array}$ & $\begin{array}{l}\text { Res. } \sigma_{t} \\
(\mathrm{MPa})\end{array}$ & $\begin{array}{l}\text { MOE } \\
\text { (GPa) }\end{array}$ & $\begin{array}{l}\text { Res. } \sigma_{t} \\
(\mathrm{MPa})\end{array}$ & $\begin{array}{l}\text { MOE } \\
(\mathrm{GPa})\end{array}$ \\
\hline \multirow[t]{2}{*}{ Base } & Sem nó & $28,36 \quad 14,65$ & 72,62 & 26,60 & 68,57 & 21,11 & 68,5 & 16,9 & \multirow{2}{*}{35,9} & \multirow{2}{*}{3,32} & \multirow{2}{*}{\multicolumn{2}{|c|}{39,90}} \\
\hline & Com nó & $25,27 \quad 9,00$ & 71,43 & 20,50 & 72,63 & 24,33 & 59,1 & 16,6 & & & & \\
\hline \multirow[t]{2}{*}{ Meio } & Sem nó & 12,25 & 78,79 & 18,00 & 79,86 & 25,36 & 70,8 & 19,0 & \multirow{2}{*}{38,6} & \multirow{2}{*}{3,85} & \multirow{2}{*}{\multicolumn{2}{|c|}{50,01}} \\
\hline & Com nó & $28,36 \quad 12,15$ & 72,72 & 26,25 & 51,29 & 22,73 & 65,4 & 15,9 & & & & \\
\hline \multirow[t]{2}{*}{ Topo } & Sem nó & 25,27 & 96,75 & 17,14 & 67,81 & 33,11 & 71,5 & 17,5 & \multirow{2}{*}{45,8} & \multirow{2}{*}{4,52} & \multirow{2}{*}{\multicolumn{2}{|c|}{47,65}} \\
\hline & Com nó & 15,80 & 75,49 & 17,75 & 75,50 & 22,30 & 65,6 & 20,9 & & & & \\
\hline \multicolumn{2}{|c|}{ Valor médio } & $29,48 \quad 12,58$ & 77,96 & 21,04 & 69,27 & 24,82 & 66,85 & 17,8 & 40,1 & 4,01 & 45,99 & 17,51 \\
\hline
\end{tabular}

\begin{tabular}{|c|c|c|c|c|c|c|c|}
\hline \multicolumn{2}{|l|}{ Autor } & \multicolumn{2}{|c|}{$\begin{array}{l}\text { Pereira } \\
(2006)\end{array}$} & \multicolumn{2}{|c|}{$\begin{array}{l}\text { Berndsen et } \\
\text { al. (2013) }\end{array}$} & \multicolumn{2}{|c|}{$\begin{array}{l}\text { Ardila Pinilla } \\
\text { (2013) }\end{array}$} \\
\hline \multicolumn{2}{|l|}{ Espécie } & \multicolumn{2}{|c|}{ D. giganteus } & \multicolumn{2}{|c|}{ P. pubescens } & \multicolumn{2}{|c|}{ Gangustifolia } \\
\hline Parâmetro & Região & $\begin{array}{l}\text { MOR } \\
(\mathrm{MPa})\end{array}$ & $\begin{array}{l}\text { MOE } \\
(G P a)\end{array}$ & $\begin{array}{l}\text { MOR } \\
(\mathrm{MPa})\end{array}$ & $\begin{array}{l}\text { MOE } \\
(\mathrm{GPa})\end{array}$ & $\begin{array}{l}\text { MOR } \\
(\mathrm{MPa})\end{array}$ & $\begin{array}{l}\text { MOE } \\
\text { (GPa) }\end{array}$ \\
\hline \multirow[t]{2}{*}{ Base } & Sem nó & 169,1 & 15,5 & \multirow{2}{*}{154} & \multirow{2}{*}{12,28} & \multirow{2}{*}{\multicolumn{2}{|c|}{-}} \\
\hline & Com nó & 118,7 & 12,6 & & & & \\
\hline \multirow[t]{2}{*}{ Meio } & Sem nó & 161,1 & 16,0 & \multirow{2}{*}{173} & \multirow{2}{*}{14,31} & \multirow{2}{*}{38,88} & \multirow{2}{*}{14,93} \\
\hline & Com nó & 104,9 & 12,3 & & & & \\
\hline \multirow[t]{2}{*}{ Topo } & Sem nó & 170,7 & 15,3 & \multirow{2}{*}{174} & \multirow{2}{*}{14,55} & \multirow{2}{*}{\multicolumn{2}{|c|}{-}} \\
\hline & Com nó & 111,9 & 12,0 & & & & \\
\hline \multicolumn{2}{|c|}{ Valor médio } & 139,35 & 13,95 & 167 & 13,71 & 38,88 & 14,93 \\
\hline
\end{tabular}

TABELA 4

Testes de flexão estática simples (transversal às fibras).

FIGURA 11

Flexão no colmo. Autor: Joan Font. 
flexão perpendicular ou quando é solicitado à tração e compressão paralela às fibras. Nos testes realizados (Tabela 5), os valores de resistência que o bambu apresenta quando submetido a esse esforço são muito baixos.

Em termos comparativos, segundo os estudos de Sanchez Cruz (2002), Ghavami e Marinho (2001, 2002) e Ardilla (2013), o cisalhamento interlaminar é muito inferior aos esforços de tração e compressão (Tabela 6). Por exemplo, a tração última no $P$. aurea em relação à tensão de cisalhamento última é 53 vezes mais elevada.

2.2.4.5

Cisalhamento transversal

Quando se trata de exercer uma força de cisalhamento perpendicular às fibras (Figura 13) ao eixo axial do bambu, está de certa forma tentando cisalhar-se a fibra na direção perpendicular. A resistência da fibra é muito elevada, assim, quando o colmo é submetido à flexão existe também uma tensão cisalhante.

Os valores com relação ao cisalhamento interlaminar são muito elevados, mais do que 10 vezes, e isso mostra o comportamento tão distinto deste material ortotrópico.

Porém, não há muitos estudos de esforço. É muito complicado exercer um esforço de cisalhamento puro no bambu, assim como na tração e compressão paralela às fibras, a falha nunca se dá no sentido das forças aplicadas, mas sempre aparece no sentido paralelo às fibras por causa de tensões residuais.

\section{2 .4 .6 \\ Tração perpendicular}

A tração perpendicular às fibras no bambu (Figura 14) provavelmente seja o ponto fraco do material. Nesse esforço, submete-se o material a uma força que basicamente tenta desagregar as fibras transversalmente, tensionando o parênquima ou as células dos vasos condutores ao seu estado limite. Qualquer tensão residual que consiga tracionar duas fibras paralelas pode fazer o material falhar.

Não existe muita literatura sobre o comportamento do bambu nesse caso, assim como também não há muitos trabalhos que explorem essa situação, provavelmente pela dificuldade de se estabelecer uma metodologia confiável para realização de ensaios.

Richard (2013) obteve alguns valores de no seu ensaio de Split-Pin (Figura 15) de $2.40 \mathrm{MPa}$ de resistência de tração paralela às fibras para o $P$. pubescens (mossô), enquanto a outra espécie tes- tada, Bambusa stenostachya (Tre Gai), apresentou apenas 1,52 MPa para teste com seções circulares de colmo.

Apesar de não haver dados comparativos de todos os testes para todas as espécies, essa tensão é, sem dúvida, a que indica os menores valores em todos os testes.

Isso significa que se deve evitar exercer tensões que provoquem o desmembramento dos feixes de fibras - por exemplo, não se deve usar pregos em construções com bambu.

2.2.4.7

Compressão perpendicular

A compressão perpendicular às fibras (Figura 16) é outra tensão que o bambu não está preparado para resistir, porém, apresenta um comportamento um pouco mais favorável do que a tração exercida na mesma direção.

Ardilla (2013) relata nos seus testes a compressão perpendicular com seções circulares, valores de tensão da ordem de 1/10 dos valores obtido nos testes de compressão paralelas às fibras.

Essa resistência tão baixa exige que, na hora de projetar com colmos de bambu, não se utilizem apoios sobre colmos de bambu horizontais, que suponham cargas concentradas no colmo, que poderiam esmagá-lo. 


\begin{tabular}{|c|c|c|c|c|c|}
\hline \multicolumn{2}{|l|}{ Autor } & $\begin{array}{l}\text { Ghavami e } \\
\text { Marinho } \\
(2001)\end{array}$ & $\begin{array}{l}\text { Ghavami e } \\
\text { Marinho } \\
(2001)\end{array}$ & $\begin{array}{l}\text { Sanchez } \\
\text { Cruz } \\
(2002)\end{array}$ & $\begin{array}{l}\text { Ardila } \\
\text { Pinilla } \\
\text { (2013) }\end{array}$ \\
\hline \multicolumn{2}{|l|}{ Espécie } & G. angustifolia & D. giganteus & P. aurea & G. angustifolia \\
\hline Parâmetro & Região & т (MPa) & $\mathrm{T}(\mathrm{MPa})$ & т (MPa) & т (MPa) \\
\hline \multirow[t]{2}{*}{ Base } & Sem nó & 2,19 & 2,33 & 3,92 & \multirow{2}{*}{4,63} \\
\hline & Com nó & 1,66 & 3,24 & 3,09 & \\
\hline \multirow[t]{2}{*}{ Meio } & Sem nó & 2,27 & 4,19 & 4,61 & \multirow{2}{*}{4,13} \\
\hline & Com nó & 1,43 & 3,23 & 3,40 & \\
\hline \multirow[t]{2}{*}{ Topo } & Sem nó & 2,42 & 3,59 & 4,64 & \multirow{2}{*}{4,65} \\
\hline & Com nó & 2,11 & 4,19 & 4,10 & \\
\hline \multicolumn{2}{|c|}{ Valor médio } & 2,07 & 3,46 & 3,96 & 4,47 \\
\hline
\end{tabular}

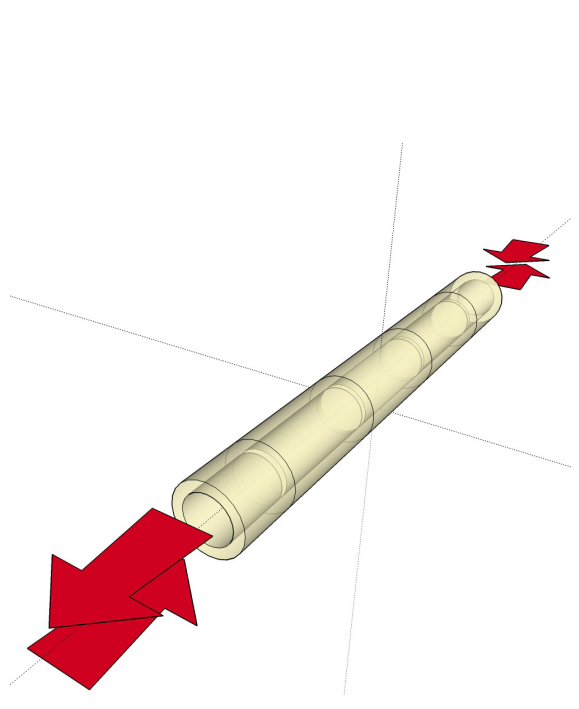

\section{FIGURA 12}

Cisalhamento paralelo no colmo. Autor: Joan Font.

\begin{tabular}{l|l|l|l|l} 
Autor & $\begin{array}{l}\text { Ghavami e } \\
\text { Marinho } \\
\text { (2001) }\end{array}$ & $\begin{array}{l}\text { Ghavami e } \\
\text { Marinho } \\
\text { (2001) }\end{array}$ & $\begin{array}{l}\text { Sanchez } \\
\text { Cruz } \\
\mathbf{( 2 0 0 2 )}\end{array}$ & $\begin{array}{l}\text { Ardila } \\
\text { Pinilla } \\
\text { (2013) }\end{array}$ \\
\hline Espécie & G.angustifolia & D. giganteus & P. aurea & G. angustifólia \\
\hline $\begin{array}{l}\text { Relação } \\
\text { compressão } \\
\text { média / } \\
\text { cisalhamento } \\
\text { médio }\end{array}$ & 14,24 & 22,53 & 17,49 & 10,28 \\
\hline $\begin{array}{l}\text { Relação } \\
\text { tração } \\
\text { média / } \\
\text { cisalhamento } \\
\text { médio }\end{array}$ & 42,00 & 40,39 & 53,13 & 14,81 \\
& & & &
\end{tabular}

TABELA 6

Testes de

cisalhamento axial

(interlaminar)

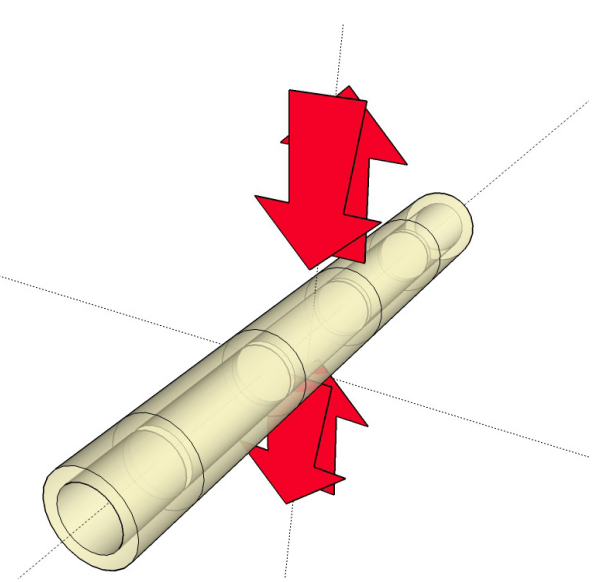

FIGURA 13

Cisalhamento

transversal no colmo. Autor: Joan Font. 
TABELA 7

Testes de

\section{cisalhamento}

perpendicular.

\section{FIGURA 14}

Tração transversal paralela às fibras Autor: Joan Font.

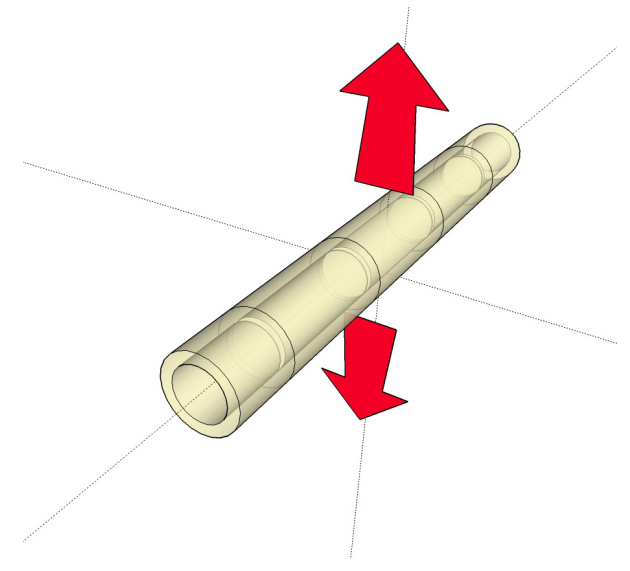

\section{TABELA 8}

Testes de

compressão

perpendicular às fibras

\section{FIGURA 15}

Compressão perpendicular às fibras. Autor: Joan Font.

\begin{tabular}{|c|c|c|c|}
\hline \multicolumn{2}{|l|}{ Autor } & $\begin{array}{l}\text { Sanchez } \\
\text { Cruz } \\
(2002)\end{array}$ & $\begin{array}{l}\text { Culzoni } \\
\text { (1986) }\end{array}$ \\
\hline \multicolumn{2}{|l|}{ Espécie } & P. aurea & D. giganteus \\
\hline Parâmetro & Região & т (MPa) & $\mathrm{T}(\mathrm{MPa})$ \\
\hline \multirow{2}{*}{ Base } & Sem nó & 44,54 & \multirow{2}{*}{47,0} \\
\hline & Com nó & 51,03 & \\
\hline \multirow[t]{2}{*}{ Meio } & Sem nó & 46,99 & \multirow{2}{*}{45,6} \\
\hline & Com nó & 47,13 & \\
\hline \multirow[t]{2}{*}{ Topo } & Sem nó & 37,84 & \multirow{2}{*}{49,0} \\
\hline & Com nó & 44,63 & \\
\hline \multicolumn{2}{|l|}{ Valor médio } & 45,36 & 47,2 \\
\hline
\end{tabular}

\begin{tabular}{l|c} 
Autor & $\begin{array}{l}\text { Ardila Pinilla } \\
\text { (2013) }\end{array}$ \\
\hline Espécie & G. angustifolia \\
\hline Unidades & MPa \\
\hline Base & 4,80 \\
\hline Meio & 4,08 \\
\hline Topo & 4,57 \\
\hline Valor médio & 4,42
\end{tabular}




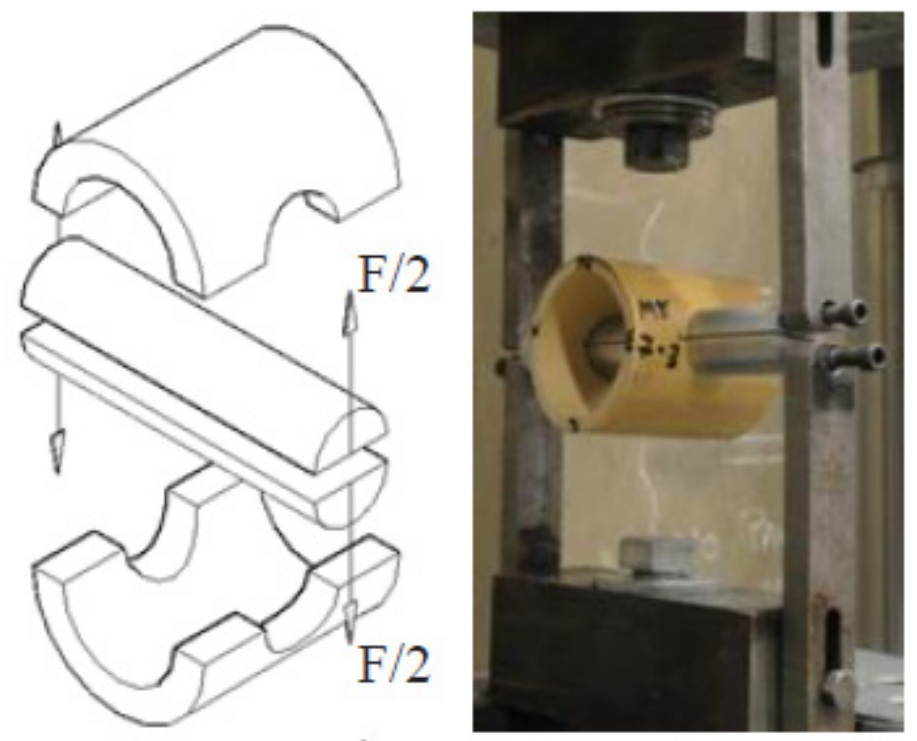

a) test set-up

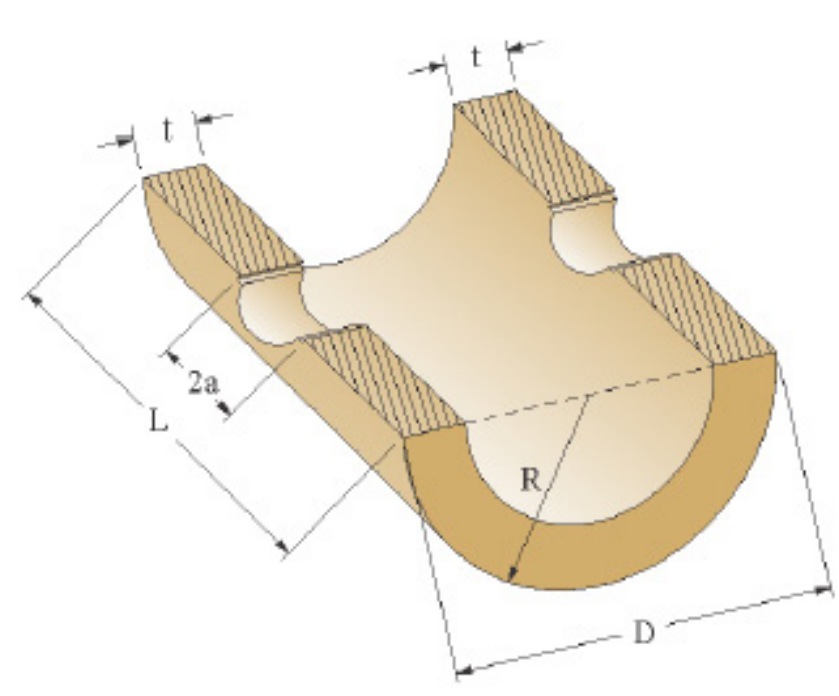

b) specimen dimensions
FIGURA 16

Teste para tração per-

pendicular Split-pin.

Fonte: RICHARD, 2013. 
2.2.4.8

Torção

Kravtsova (2011) expõe, a partir dos resultados da sua pesquisa, que quando o colmo de bambu é submetido à torção (Figura 17), as maiores deformações aparecem nos pontos críticos, ou seja, nas extremidades livres e na região perto da fixação. Quando o bambu colapsa, a fissura produzida deforma as extremidades, e o resto do colmo tem um comportamento basicamente elástico. O ângulo de rotação máximo atingido é de $12^{\circ}$ com torque aplicado de $200 \mathrm{kN}$.mm (Figura 18).

\subsection{5}

Material compósito funcionalmente graduado

Segundo a definição de Ghavami, Rodrigues e Paciornik (2003), o material do bambu é um compósito constituído por fibras de celulose alongadas e alinhadas, embutidas numa matriz de lignina.

As proporções e distribuições desses componentes variam de acordo com a posição em todos os níveis estruturais do colmo. E tanto os parâmetros macroestruturais (diâmetro, espessura, espaçamento entre nós) da fração volumétrica de fibras na espessura da parede) que definem o bambu se desenvolveram de modo a otimizar o volume do material diante dos esforços aos quais este está sujeito na natureza. Esses esforços são basicamente o peso próprio que age como uma carga axial de compressão, e o vento que age como a carga horizontal distribuída, que faz o bambu trabalhar à flexão, criando momentos fletores na base do colmo. O resultado da evolução da planta para se adaptar a esses fatores resulta em um material leve com respostas excepcionais a solicitações mecânicas. Essa otimização do material é o que Nogata e Takahashi (1995) denominam de funcionalidade graduada (Figura 19).

A massa específica da parte mais externa do colmo é maior do que a da parte interna do colmo devido a uma concentração de fibras muito maior. (CUSACK, 1997 apud LIESE, 1998).

A massa específica aumenta da base do colmo até o topo, porém, o diâmetro do colmo diminui, dando a ele uma leve forma cônica e maior inércia à seção do colmo para resistir melhor ao momento flexor máximo, que acontece na base que, abstratamente, pode-se considerar como um engaste.

Os nós agem como estribos e me- lhoram o comportamento do bambu ao cisalhamento decorrente da carga horizontal do vento.

\section{3}

\section{Fatores de influência na anato- mia do bambu}

O crescimento do bambu está associado às condições ambientais que podem interferir no desenvolvimento dos tecidos e, portanto, nas propriedades químicas, físicas, mecânicas e geométricas. Esses condicionantes são, segundo Hidalgo-López (2003), o clima (determinado pela latitude, temperatura e regime pluviométrico), solo, altitude e topografia. Por outro lado, a idade do colmo também é um aspecto relevante na estruturação microscópica do material, e deve ser considerado, principalmente, na etapa da colheita.

\subsection{1}

Clima

O bambu se desenvolve bem em climas tropicais e subtropicais, especialmente as espécies entouceirantes que precisam de calor e umidade, que, como descreve Salgado (2014), se desenvolvem melhor em regiões com altas temperaturas com oscilações 
suaves das condições climáticas, tanto do regime de chuvas como de variações térmicas acentuadas. As espécies alastrantes, muitas delas encontradas em latitudes temperadas do planeta, suportam melhor temperaturas baixas, podendo sobreviver abaixo de $0{ }^{\circ} \mathrm{C}$ nas estações de inverno.

Segundo Liese (1998), há variações consideráveis nos valores médios encontrados na literatura, particularmente quando a origem das amostras não tem sido considerada. Qualquer parâmetro mensurado deve levar em consideração padrões de variação dentro do colmo, tomando amostras representativas e avaliando a localização original.

A umidade que pode conter o colmo de bambu pode variar consideravelmente ao longo dos ciclos estacionários. Durante épocas chuvosas, o teor de umidade relativa do colmo é muito maior do que em épocas secas.

A grande diferença entre os valores de teor de umidade máximos e mínimos obtidos durante um ano revela a enorme capacidade de armazenagem que as células de parênquima possuem.

Estudos de Gnanaharan (1994 apud HIDALGO-LÓPEZ, 2003) revelam que bambus de uma mesma espécie podem ter crescimentos diferenciados dependendo da umidade do ambiente onde estão inseridos.
O crescimento em áreas mais úmidas produz colmos com maiores dimensões do diâmetro e de altura de internós, porém, com menor módulo de ruptura e de elasticidade em comparação com bambus de uma região mais seca.

\subsection{2}

Solo

O bambu, em geral, cresce em solos férteis a determinada altitude. Segundo os estudos de Deogun (1936 apud Hidalgo-López, 2003), comprovou-se que o bambu adquire melhores propriedades mecânicas quando é cultivado em solos com uma granulometria grosseira derivados de solos rochosos ou graníticos e, acima de tudo, solos secos com uma boa capacidade de drenagem natural, pois a concentração de água durante o crescimento não permite um bom desenvolvimento dos tecidos celulares esclerenquimáticos.

\subsection{3}

Altitude

Estudos realizados pelo Instituto Colombiano de Normas Técnicas y Certificación (ICONTEC) revelam que a espécie $G$. angustifóoia apresenta as melhores propriedades mecânicas quando cresce em regiões

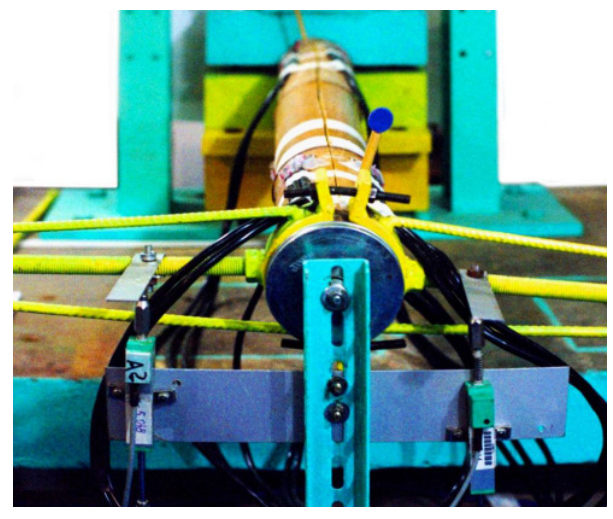

FIGURA 17

Equipamento de ensaio de torção. Autor: KRAVTSOVA, 2011.

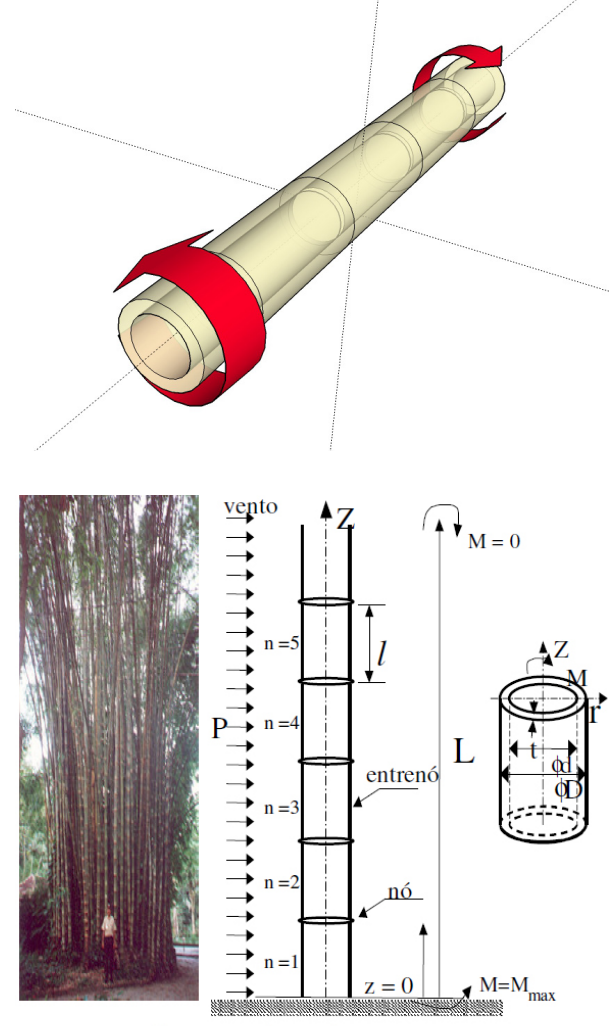

FIGURA 18

Torção no colmo. Autor: Joan Font.

FIGURA 19

Ações do vento no colmo. Fonte: GHAVAMI, 2005. 
em cerca de $1.400 \mathrm{~m}$ de altitude, apesar de crescer em áreas ao nível do mar e até os $1.800 \mathrm{~m}$. Dois bambuzais da mesma espécie crescidos em diferentes localizações geográficas podem diferir substancialmente nas suas propriedades mecânicas e geométricas, dessa forma, torna-se recomendável fazer estudos de cada espécie em relação as características geográficas e geológicas do terreno.

\subsection{4 \\ Topografia}

Estudos apresentados por Soeprayitno et al. (1988 apud HIDALGO-LÓPEZ, 2004) revelaram que bambus da espécie Gigantochloa pseudo-arundinacea plantados em terrenos muito inclinados tinham valores de resistência mecânica, peso específico e módulo de elasticidade muito maiores do que quando plantados em vales.

Por outro lado, Abd. Latif (1995 apud LIESE, 1998), comparando o crescimento e as propriedades mecânicas de Gigantochloa scortechinii cultivados em quatro terrenos com diferentes caraterísticas, determinou que não havia diferenças consideráveis nos colmos e, portanto, a topografia não era um fator determinante.

Esses dois exemplos mostram que determinar a influência da topografia no crescimento e nas propriedades físico-mecânicas do bambu.

\subsection{5}

Idade

A idade do bambu e as mudanças que sofre durante seu crescimento e maturação influenciam certas propriedades e, consequentemente, seu processamento e utilização (LIESE, 1998).

A idade é um fator muito importante para o desenvolvimento de certas propriedades mecânicas do colmo, pois a partir do terceiro ano de idade o colmo atinge sua resistência mecânica máxima (HIDALGO-LÓPEZ, 2003).

Devido ao crescimento telescópico do bambu, o topo do colmo tem menos parênquima e uma quantidade de feixes vasculares muito grande, apesar destes serem mais delgados, o que dá ao terço apical do colmo uma massa especificamente maior e consequentemente um desempenho mecânico melhor

$\mathrm{O}$ incremento da resistência mecânica do bambu se dá exclusivamente pelo crescimento da espessura das paredes das fibras.

Segundo Alam e Murphy (1988 apud LIESE, 1998), a concentração de amido varia de acordo com a idade do colmo. Nos colmos mais jovens, a concentração de amido é muito baixa ou quase inexistente. Por outro lado, o teor de amido nos colmos a partir de 3 anos é muito elevado. Isso supõe certa contradição a efeitos da colheita, porque é a partir do terceiro ano que o colmo assume as propriedades mecânicas adequadas para o uso na construção, mas, por outro lado, fazem-se necessários o tratamento e a extração do amido, para um correto desempenho e durabilidade.

Beraldo e Pereira (2008) determinam que colmos de 1 a 2 anos são considerados jovens e não aptos para uso estrutural na construção civil; após o terceiro ano, os colmos adquirem as propriedades mecânicas mais adquadas e podem ser utilizados para tais fins; a partir do oitavo ano, essas caraterísticas começam a diminuir, pois termina seu período de vida útil.

Com o passar do tempo, os vasos condutores do bambu se obstruem, impedindo a circulação de água e seiva pelo colmo, causando a deterioração e o colapso do sistema, perdendo completamente a resistência mecânica e finalizando sua vida útil, motivo pelo qual devem ser eliminados da touceira. 


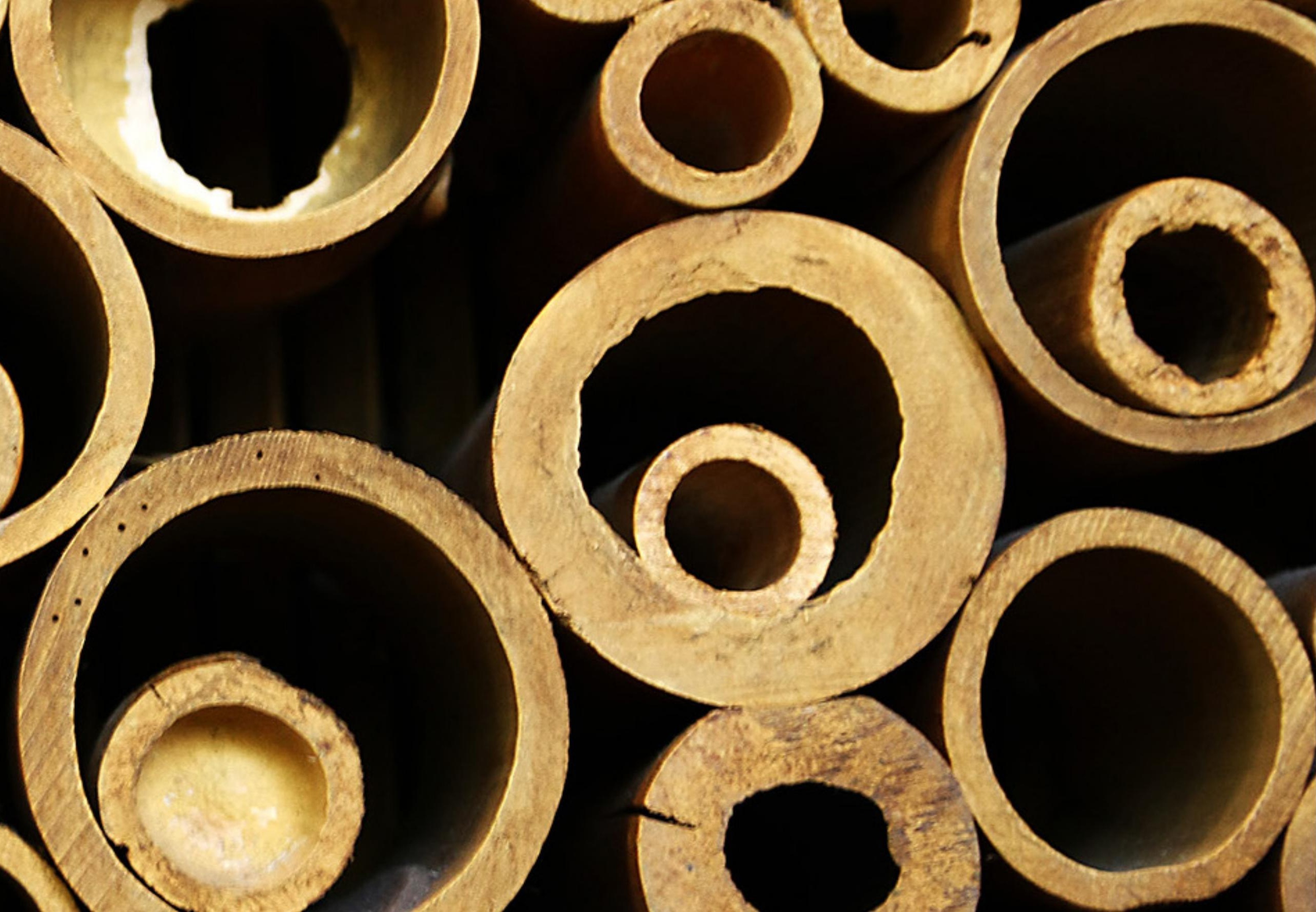




\section{Capítulo 3}

\section{Processamento e manejo do}

bambu para construção civil

A cultura do bambu, assim como o processamento prévio à sua utilização, em construções e em estruturas, é uma parte essencial e necessita de muita consideração por parte daqueles que utilizam esse material.

Por ser um material orgânico produzido em condições ambientais não controladas pelo ser humano, suas propriedades podem mudar significativamente não só entre colmos de diferentes espécies, localizações geográficas ou touceiras; as diferenças podem ocorrer entre colmos de uma mesma moita. A variabilidade do material na sua composição microestrutural assim como na geometria macroestrutural é um dos seus principais defeitos, e a necessidade de criar processos metodológicos agronômicos para atingir uma mínima regularidade nas propriedades é uma necessidade primordial para a disseminação do bambu como matéria-prima na edificação.

O cultivo do bambu tem uma in- fluência direta na consolidação de certas caraterísticas físicas dos tecidos do material, e como consequência nas suas propriedades mecânicas ${ }^{1}$.

É importante conhecer as particularidades das condições ambientais, para selecionar as espécies adequadas, visando conseguir um bambu de qualidade com rápido crescimento, bom rendimento na produção de brotos, boas propriedades mecânicas para, dentro de uma lógica mercantilista, obter o máximo de lucro para os produtores (HIDALGO-LÓPEZ, 2003).

O manejo correto do bambu, otimizando as plantações, controlando os tempos e os ciclos da planta, permite uma exploração eficiente dos bambuzais, beneficiando não só o meio ambiente como também os produtores, fazendo do bambu um material mais atraente para os agentes envolvidos no setor da construção civil.

1. "na anatomia do bambu" 
Para Hidalgo-López (2003), o meio físico necessário para que o bambu tenha um bom desenvolvimento vária muito entre as espécies, contudo, o bambu é uma planta com uma resiliência muito elevada, o que possibilita seu crescimento em situações e contextos muito diversos.

\section{1}

\section{Cultivo do bambu}

A silvicultura do bambu é a cultura de suas plantações, da tecnologia e dos métodos de propagação e reflorestamento (HIDALGO-LÓPEZ, 2003).

A premissa do manejo é a seleção da espécie adequada baseada no uso final do bambu, o clima e as caraterísticas do entorno, tanto ecológicas como socioculturais (JANSSEN, 2000).

A fase do cultivo visa controlar o crescimento da planta para conseguir colmos com determinadas caraterísticas físico-mecânicas e geométricas que as tornem apropriadas para a construção civil, além de almejar uma elevada produtividade das moitas.

Tendo em vista os efeitos do cultivo massivo para obtenção de bambu como matéria-prima com o objetivo de ser comercializado, é preciso controlar minuciosamente certos aspectos de planejamento e ter muito claro o sistema de propagação do bambu que se pretende cultivar, já que a disposição e gerenciamento de uma plantação de bambu do tipo leptomorfo é completamente distinta do bambu paquimorfo.

Por ser o bambu um recurso natural que cresce naturalmente nas intempéries, está exposto a diversos fatores externos que podem não só influenciar no rendimento de um plantio como nas propriedades físicas e mecânicas do material; portanto, precisa-se de certa padronização na qualidade e nas propriedades do bambu para que não tenha comportamentos imprevistos. Assim, a preparação da área do terreno e o cuidado duran- te o crescimento do bambu são quase tão importantes quanto os processos que sucedem ao corte do colmo.

A qualidade do terreno onde será feita a plantação afeta diretamente os custos de produção, o transporte e a qualidade do estoque produzido.

Antes da semeadura, o solo do futuro bambuzal precisa de um preparo geral e são necessárias algumas ações, como arejar o solo para aumentar e preservar a fertilidade e umidade, remover plantas (ervas daninhas) que concorrem pelos nutrientes e a água do solo e que podem dificultar o crescimento, além da esterilização do terreno para evitar pragas e agentes biológicos destrutivos.

A melhor época para plantar o bambu, para aproveitar as condições climáticas ótimas para um bom enraizamento e para que as propriedades dos colmos sejam futuramente as mais adequadas, é durante a época de chuvas, já que a temperatura elevada e o regime 
pluviométrico alto facilitam o desenvolvimento inicial, melhorando a formação do sistema subterrâneo. Se houver um sistema de irrigação, o plantio pode ser feito durante a estação seca para desenvolver mais rapidamente as mudas quando chegar a estação de chuvas.

Deve-se considerar vários fatores na hora de planejar uma área para cultivo de bambu para fins comerciais e explorar assim os recursos que o bambu oferece (SALGADO, 2014):

1) Definição da área de cultivo. O bambu é uma espécie altamente invasiva, e precisa-se determinar claramente o espaço até onde ficam os limites do bambuzal, para evitar a invasão de terrenos contíguos. Nesse ponto também é importante saber se há possibilidades de futuras expansões, devido a um aumento de demanda. Também é necessário saber a proximidade de mananciais para uma eventual necessidade de suplementar água para um crescimento adequado e otimizado da plantação.

2) Topografia plana. O bambu pode ser cultivado em diferentes situações topográficas, inclusive nas mais adversas, como terrenos com vertentes muito grandes. O importante neste sentido é considerar o acesso ao bambuzal e o método de remoção e transporte dos colmos colhidos, tentando sempre facilitar a exploração a partir de uma logística adequada. Terrenos com menor declividade, sem muitos acidentes topográficos, são recomendados para facilitar o plantio, tratamento, corte, colheita e remoção.

3) Fertilidade do solo. Avaliar a capacidade do solo de sustentar uma plantação de bambu. Em terrenos deficientes deve-se ajustar com adubo e nutrientes externos para favorecer o crescimento.

4) Distância do local de consumo da matéria-prima. O custo de transporte até o consumidor pode inviabilizar economicamente a plantação, assim como converter em negativa a pegada de carbono do bambuzal. As emissões que o transporte do bambu gera devem ser estudadas e confrontadas com a captura de dióxido de carbono que o bambuzal tem, para avaliar se o balanço ecológico da plantação é positivo.

\subsection{1}

\section{Preparação do terreno para o plantio}

Para conferir ao terreno do bambual as condições ótimas, Salgado (2014) estabelece algumas ações prévias ao plantio, como o desmatamento e retirada da vegetação do local, sem eliminar a camada superficial vegetativa do terreno, encoivaramento, enleiramento, catação, gradagem, calagem, coveamento e, finalmente se for necessária, fertilização do terreno (Figura 1 ).

Os critérios para a disposição das mudas no terreno dependerão da topografia, mas também da finalidade de exploração do bambu. Para espécies entouceirantes voltadas para a construção, são recomendados espaços de 3,5 $\mathrm{m} \times 7 \mathrm{~m}$. As covas para plantio devem ter $40 \mathrm{~cm} \times 40 \mathrm{~cm} \times 40 \mathrm{~cm}$, recebendo as dosagens ideais de calcário, fertilizantes químicos e matéria orgânica (SALGADO, 2014).

Pereira e Beraldo (2008) apontam que o espaçamento adequado tem de ser feito prevendo o crescimento de acordo com o porte da espécie. Quando a espécie é entouceirante de pequeno porte, o espaçamento é de $5 \mathrm{~m} \times 5 \mathrm{~m}$, para espécies de grande porte o espaçamento deve ser de $8 \mathrm{~m} \times 7 \mathrm{~m}$, para facilitar a colheita e a logística - poder entrar com veículos de transporte dentro do plantio. Para as espécies alastrantes, não especificam o espaçamento, porque o desenvolvimento da planta é um pouco imprevisível e tende a ocupar gradativamente a totalidade do terreno. 


\subsection{2}

\section{Tratamento durante o plantio}

Existe a necessidade de manter o bambu-planta sem ervas daninhas concorrentes, e dificultar o crescimento, assim como é preciso evitar o ataque de insetos e fungos. Deve-se limpar de ervas indesejadas até um raio de $1 \mathrm{~m}$ da muda, para evitar a "luta" pelos fertilizantes e pela água do solo. O procedimento de limpeza dos arredores deve ser feito a cada quatro meses durante os dois primeiros anos, e, a partir de então, poderá ser feito a cada seis meses (Figura 2). Deve-se controlar as condições de crescimento da planta, pela necessidade de agregar fertilizantes ou implantar um sistema de irrigação caso o regime de chuvas no local do plantio seja insuficiente - isso significa abaixo dos $1.200 \mathrm{~mm}$ anuais. $\mathrm{Na}$ fase inicial de crescimento, as regas devem ser constantes.

\subsection{3}

\section{Adubação}

Existem dois tipos de adubação: aquela que é feita durante a preparação do terreno, antes de plantar a muda, quando se misturam no solo diferentes produtos químicos e/ou orgânicos, e aquela feita uma vez consolidada a planta para a manutenção e crescimento vigoroso.

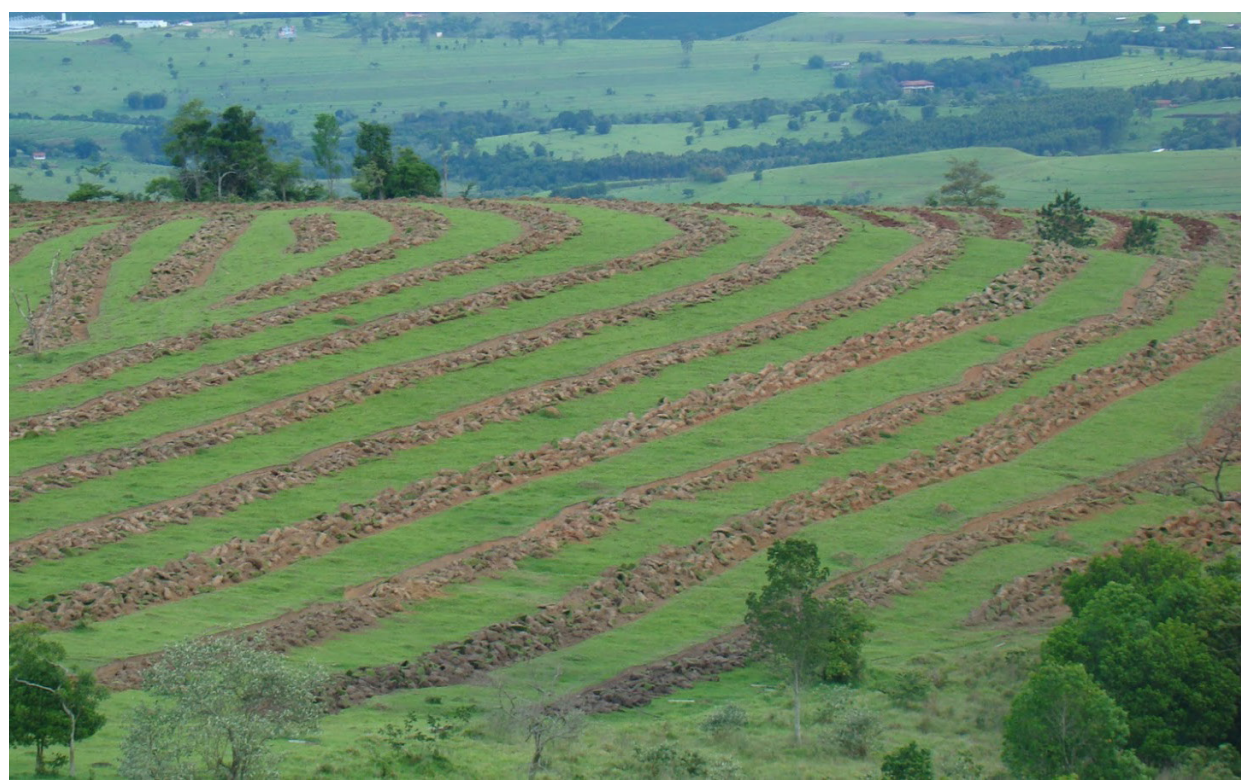

FIGURA 1

Preparação para plantação de G. angustifolia na Colômbia. Disponível em: <http://eliseupinheirolopes.blogspot. com.br/2012/05/ resumo-das-apostilas-sobre-producao-de.html>. Acesso em mar. 2017.

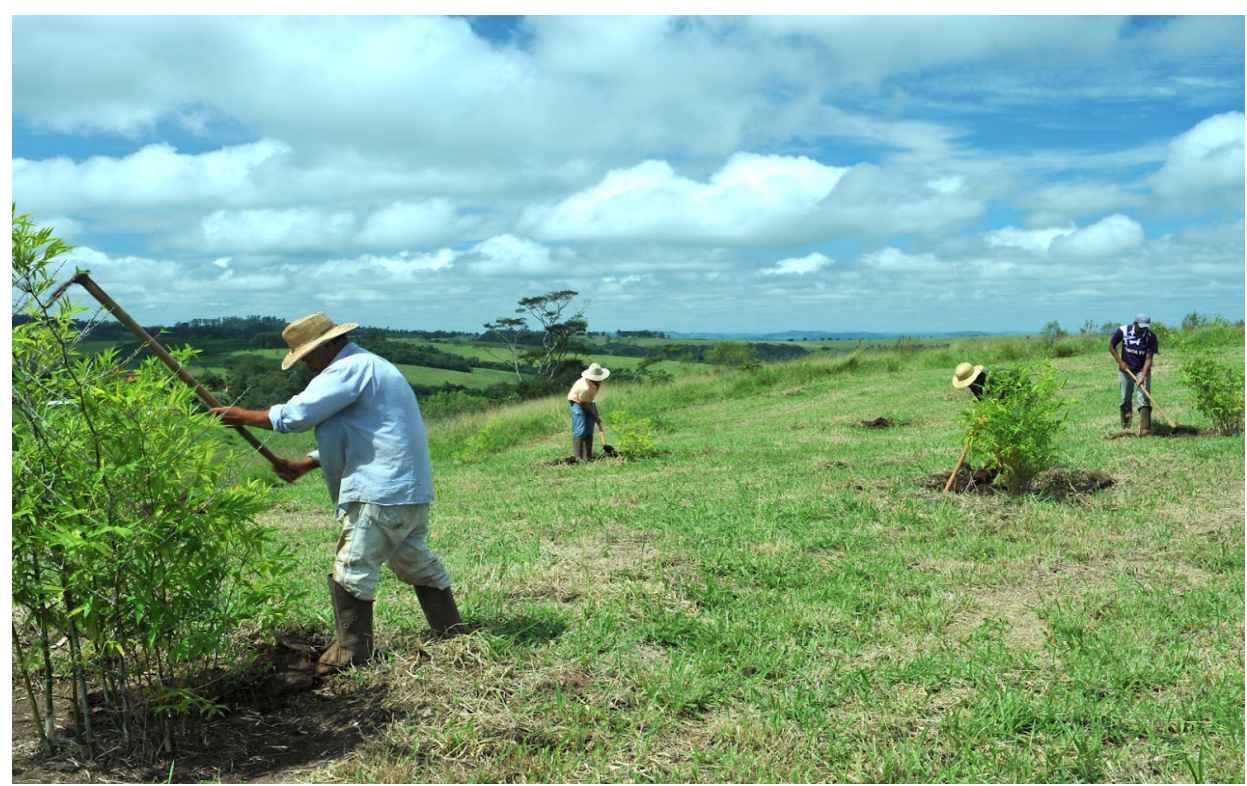

FIGURA 2

Limpeza do terreno para proteção dos brotos na Colômbia. Disponível em: <http://eliseupinheirolopes.blogspot. com.br/2012/05/ resumo-das-apostilas-sobre-producao-de.html>. Acesso em mar. 2017. 
Liese (1998) e também Lakshamana (1994) afirmam que a fertilização aumenta a produção de colmos e as propriedades macroestruturais, como o diâmetro e a altura. Mas a composição anatômica se mantém, assim como seu comportamento mecânico.

O bambu necessita de grandes aportes de nitrogênio para gerar e produzir o crescimento de brotos por meio da fórmula de 20-5-20 NPK (fertilizantes químicos baseados em nitrogênio, fósforo e potássio), em três fases, no começo, no meio e no final da estação de chuvas, aumentando gradativamente a cada ano até os 5-7 anos. É importante também corrigir a alcalinidade do solo, pois sempre deve-se manter com um $\mathrm{pH}$ superior a 5,5 (PEREIRA; BERALDO, 2008).

\subsection{4}

\section{Rendimento do plantio}

Os bambus tropicais têm uma produtividade muito maior que os de clima temperado. A produção é considerada por unidade de peso para um hectare e um ano, mas, em vez de peso, pode-se considerar o número de colmos. Porém, a produtividade é bastante variável dependendo das condições locais do clima e do solo.

Segundo Pereira e Beraldo do crescimento e da produtividade das moitas cultivadas na Universidade Estadual Paulista Júlio de Mesquita Filho (Unesp) em Bauru (SP), no ano de 2008, o número de colmos por anos que brotam se mantém em 8 ou 9 , mostrando certa irregularidade na altura dos colmos com o passar dos anos; o diâmetro, por sua vez, só aumenta.

\subsection{5}

\section{Propagação do bambu}

O bambu é uma planta perene que produz colmos assexuadamente todos os anos sem necessidade de replantio, tem um grande rendimento anual, rapidez de crescimentos e não precisa de solos excessivamente férteis.

Possui grande facilidade de propagação e reprodução, mas se torna uma tarefa complicada na hora de controlar seu crescimento e, sobretudo, na erradicação de touceiras do tipo alastrante. Trata-se de uma planta muito invasiva, que se desenvolve com muita facilidade em terrenos muito acidentados, pode até ser considerada uma praga vegetal, quando não se tem um controle efeitivo da sua expansão (Figura 3).

O bambu alastrante brota duran(2008), durante o acompanhamento te a estação da primavera. O manejo dessas espécies é mais adequada por conta da facilidade de acesso a todos os colmos, já os bambus entouceirantes, uma vez formados, podem apresentar dificuldades devidas à acumulação de colmos em pouco espaço.

A reprodução de bambu por meio de sementes é muito rara, mas quase todas as partes do bambu podem ser utilizadas como material de plantio, rizomas, raízes, colmos, galhos, gemas, frutos, sempre que se seguem as normas específicas para cada procedimento de cada elemento.

Sistemas de propagação que usam ramos de bambu ou pedaços de rizoma podem causar danos irreversíveis no bambu matriz. As lesões no tecido do bambu danificam o sistema vascular interrompendo o funcionamento e o desenvolvimento da planta, levando à deterioração parcial ou total das células e finalmente à morte do colmo. Os colmos que sofreram uma amputação são totalmente descartados para um possível uso na edificação. Apesar de tudo, segundo Salgado (2014), os melhores métodos para a propagação dos bambus são por meio de mudas formadas por ramos secundários para reprodução de espécies entouceirantes e por desdobramento de rizomas para as espécies alastrantes. 
3.1.6

Maturação dos colmos

O colmo de bambu pode ser aproveitado de diversas formas e cada fim tem seu tempo de maturação para estar num estado ótimo no momento da colheita.

Ter um manejo controlado, etiquetando e catalogando todos os colmos desde a sua brotação, é o modo mais adequado para controlar as idades dos colmos e para ter um correto tempo de colheita para maximizar a produção.

Durante o primeiro ano, o colmo se caracteriza por ter poucas folhas e ramos, uma cor esverdeada e folhas caulinares cobrindo o colmo.

Depois do primeiro ano de idade, o colmo perde suas bainhas e dele crescem ramos e folhas enquanto a cor começa a ficar mais amarelada. Os colmos maduros começam a ficar mais no interior da touceira, e os novos colmos aparecem na parte externa da touceira.

Liese (1998), citando Banik (1993), aponta que os colmos mais jovens apresentam certas caraterísticas que facilitam sua identificação, para assim evitar o abate precoce. Por exemplo, a presença de bainhas, padrões de ramificação, cicatrizes foliares, e coloração do colmo.

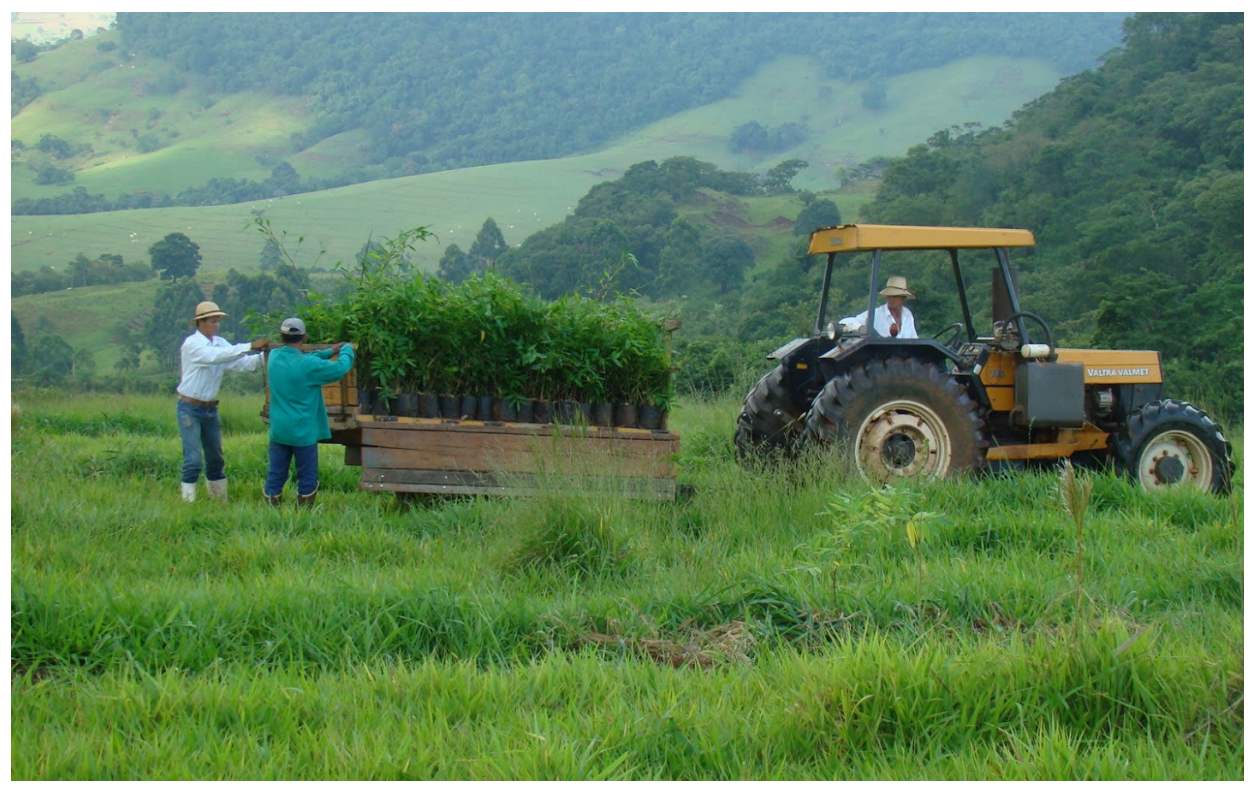

FIGURA 3

Plantio de mudas de G. angustifolia na Colômbia.

Disponivel em: $<$ http://eliseupinheirolopes.blogspot. com.br/2012/05/ resumo-das-apostilas-sobre-producao-de.html>. Acesso em mar. 2017. 
A espessura das paredes celulares das fibras aumenta durante a maturação do colmo, aumentando a sua resistência mecânica. A partir dos 3 anos de idade, as células de parênquima ao lignificarem também têm um aumento das paredes (ALVIN; MURPHY, 1980), processo que faz aumentar também a massa especifica dos colmos mais maduros, mas que, por outro lado, cria problemas na condução de nutrientes pelos feixes vasculares pela diminuição da seção dos vasos, que podem inviabilizar a circulação de água e seiva. Esse processo começa no topo do colmo onde os vasos apresentam menor diâmetro e se propaga em direção à base, deteriorando-o gradativamente e levando-o à morte.

Quando o colmo de espécies de grande porte tem entre 10 e 12 anos, o processo de colapso do sistema vascular já está muito avançado, o que provoca a ausência de nutrientes e água nos tecidos, e isso seca os colmos e os fragiliza. A perda de resistência mecânica se manifesta na forma de rachaduras nas paredes do colmo (PEREIRA; BERALDO, 2008). A ausência e esgotamento do amido precede a floração dos colmos (LIESE; KÖHL, 2015).

Para fins estruturais, o colmo tem de ser cortado entre o terceiro e sétimo ano de vida.
Faz-se uma distinção de quatro tipos de colmo nas touceiras de acordo com a idade e com o uso que pode ser feito dependendo do seu estado de maturação uma vez colhido (HIDALGO-LÓPEZ, 1974) (Figura 4):

1) Brotos, de até 30 dias de idade, utilizados para alimentação, muito comum na Ásia;

2) Brotos, entre 6 meses e 1 ano de idade, utilizados para fazer artesanato e cestaria;

3) Colmos jovens, de 1 a 3 anos de idade, para fazer alguns componentes de bambu, ripas, esterillas e mobiliário.

4) Colmos maduros, com mais de 3 anos de idade, utilizados para estruturas arquitetônicas e para fabricação de componentes laminados destinados à construção civil.

\section{2}

\section{Colheita}

Se durante o cultivo eram determinadas muitas das propriedades físicas do bambu, os processos que sucedem à colheita estabelecerão um parâmetro essencial para o desempenho do material como elemento construtivo: sua durabilidade.

A partir do momento que o bambu é abatido e deixa de ser um ser vivo, tem início uma série de mudanças fisiológicas no colmo que leva à deterioração de seus tecidos celulares e a um lento processo de degradação natural que precisa ser evitado ou, pelo menos, graças à ação humana, desacelerado. Dessa maneira, o bambu poderá ser utilizado e manipulado para os fins desejados.

Para um manejo correto, a primeira colheita é realizada no quarto ano, quando são retirados os colmos que se formaram no primeiro ano; no quinto ano, são retirados os colmos que brotaram no segundo ano, e assim por diante (Gráfico 1).

Liese (1985) recomenda abater o bambu durante a estação seca, pois os colmos apresentam menor quantidade de água nos tecidos, o que faz com que eles sejam menos pesados e menos propensos aos ataques de agentes biológicos; já o teor de seiva interna é menor, e a seiva é justamente o alimento de certos insetos. Também o teor de amido armazenado nos tecidos esclerenquimáticos durante a estação seca torna os bambus menos atraentes aos ataques de fungos, o que aumenta a sua durabilidade.

É preciso selecionar os colmos maduros e descartar (caso a utilização seja para fins construtivos) aqueles que secaram. Colmos mais jovens e não desenvolvidos devem permanecer na touceira e não serem colhidos, pois precisam amadurecer 
para que as propriedades mecânicas sejam adequadas para sua utilização. Os colmos devem ser colhidos anualmente para que não haja congestionamentos na touceira, pois os colmos velhos consomem mais recursos que podem ajudar os colmos mais jovens a se desenvolverem melhor.

Para a estocagem do bambu, como em quase todos os processos, é necessário um local ventilado evitando a radiação direta solar e a exposição à chuva.

\subsection{1}

\section{Corte de bambu}

Há dois tipos de corte para extração da matéria-prima: o corte total arrasante e o corte seletivo. Para fins de construção civil e artesanato, usa-se o corte seletivo programado, dando atenção à idade do colmo assim como à sua qualidade. Em geral, usa-se o "corte em haste", que é um corte manual feito com uma foice especial e que visa aproveitar somente os colmos, são removidos e desprezados os ramos, para que fiquem no terreno como material orgânico e, dessa forma, facilitar o transporte no caminhão para aumentar a carga. O corte do bambu deve ser rente do chão, acima do nó, e não deve deixar o bambu rachado

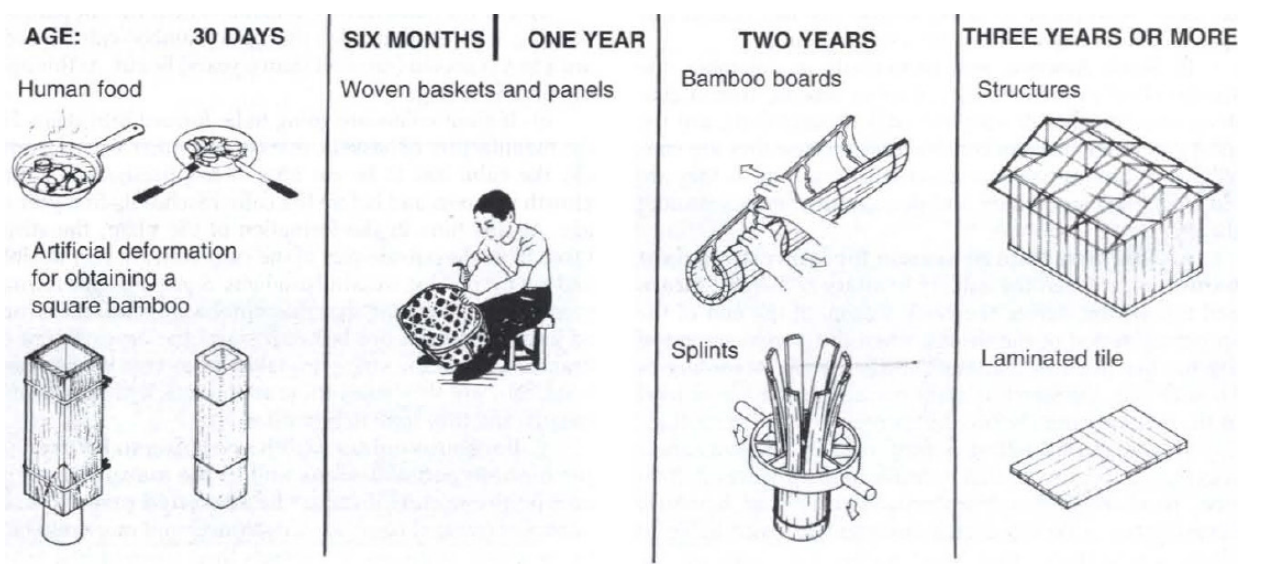

FIGURA 4

Aproveitamento dos colmos segundo a idade. Fonte: HIDALGO-LÓPEZ, 1974.

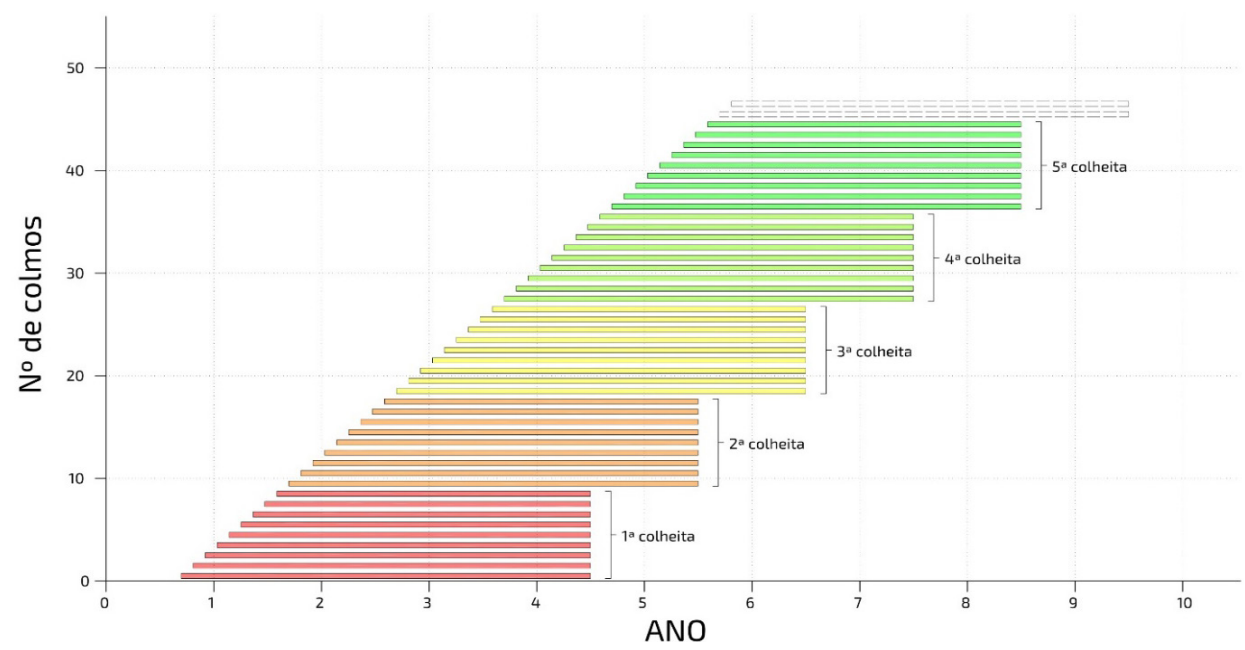

GRÁFICO 1

Padrão de colheita dos colmos da touceira. Autor: Joan Font. 
ou lascado (Figura 5). O corte deve se realizar nos meses mais frios, quando a atividade dos insetos é menor e quando a quantidade de água no ambiente também é menor, na época seca. Os bambus cortados prematuramente são mais suscetíveis a serem atacados por insetos (SALGADO, 2014).

Os cortes devem ser feitos perto do solo para as espécies alastrantes, já que os rizomas estão protegidos pelo solo.

Para as espécies entouceirantes, o corte deve ser feito no primeiro nó que fique a aproximadamente $20 \mathrm{~cm}$ do solo. $\mathrm{O}$ acúmulo de água no internó exposto, suporia prolongar o contato de água com os tecidos mais porosos do bambu e o decorrente apodrecimento do restante do colmo e do rizoma (Figura 6).

\section{3}

\section{Secagem}

A secagem tem como intuito a eliminação total ou parcial da água contida no colmo, para assim conseguir, por um lado, estabilizar dimensionalmente o bambu, evitando modificações geométricas não previstas que possam comprometer o desempenho dos elementos estruturais, e, por outro, evitando a aparição de agentes biológicos que se desenvolvem em ambientes com teor de umidade favorável.

Quando o bambu é destinado a construções temporárias, não se aplicam tratamentos preservativos, mas quando é utilizado em edificações permanentes precisa passar por um processo prévio de secagem, a fim de controlar variações dimensionais decorrentes da perda de água. Essas variações podem provocar tensões em certos pontos da estrutura, fazendo-a colapsar ${ }^{2}$.

Os colmos abatidos precisam de dois meses para perder sua umidade interna e estabilizar suas dimensões, que, ao encolherem pela perda de água, podem comprometer as uniões estruturais. Liese (1985) relata que os diferentes comportamentos do bambu durante a secagem estão ligados à espessura da parede. No mesmo colmo existem diferentes velocidades de secagem: a parte basal seca mais lentamente; no que se refere à idade, colmos jovens secam mais rápido do que os maduros.

A perda de água do colmo não é constante, e existe uma desaceleração na perda de umidade, sendo rápida no começo e mais lenta com o passar do tempo.

Os bambus secos não sofrem ata- ques de fungos. Isso implica que o ambiente onde forem utilizados em obra deve estar protegido da umidade.

Salgado (2014) enumera os diferentes métodos de secagem:

1) Secagem ao ar. Secagem em local coberto, evitando o contato com superfícies úmidas (solo) e com intempéries. A variabilidade climática pode modificar a microestrutura do colmo e, em decorrência, as suas propriedades mecânicas (Figura 7).

2) Secagem em estufa. Método mais rápido e eficiente; as peças já serradas do bambu são colocadas em um ambiente com controle de temperatura e umidade.

3) Secagem a fogo aberto. Coloca-se o bambu a $50 \mathrm{~cm}$ do fogo e girando-o para que perca toda a umidade. A variação brusca de temperatura pode criar tensões não previstas e rachaduras no bambu.

Salgado (2014) enumera alguns dos benefícios desse processo primário de tratamento dos colmos:

1) Estabilizar dimensões do colmo. Após a secagem, o bambu perde entre 85 e $90 \%$ do teor de umidade que continha naturalmente. Essa variação no teor de umidade é também refletida nas dimensões do colmo.

2) Redução do peso do colmo.

3) Redução de ataques de agentes

2 Ver 2.2.3.3 Estabilidade dimensional. biológicos. 
4) A resistência mecânica do bambu aumenta de forma inversamente proporcional ao teor de umidade dele.

5) Adesivos e elementos aglomerantes utilizados em construções ou na fabricação de componentes feitos com bambu têm melhor desempenho com o material seco.

6) As soluções preservativas penetram melhor nos tecidos do bambu quando seco, pois ocupam o espaço liberado pela água.

7) O bambu é mais fácil de ser trabalhado quando está seco, permitindo a obtenção de acabamentos mais sofisticados.

\section{4 \\ Preservação}

Todo ser vegetal é suscetível a ser atacado por outros seres vivos, no caso do bambu não é exceção: insetos e fungos são as principais ameaças para a planta. Para evitar a deterioração por parte de agentes biológicos dos bambus abatidos, é necessário interferir nos tecidos do bambu, seja por mecanismos físicos ou por processos químicos. Dessa forma, é possível aumentar a durabilidade do bambu e, consequentemente, a vida útil das estruturas construídas.

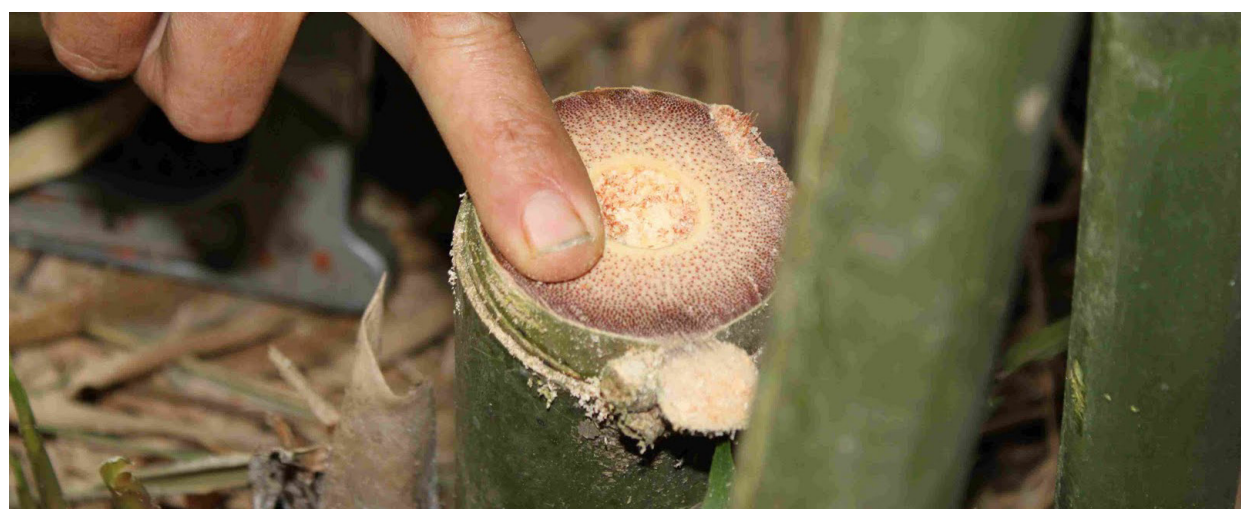

FIGURA 5

Corte correto de bambu. Disponivel em: <http://ipdtaipal.blogspot.com. br/2011/06/colheita-de-bambus-em-maio-de-2011.html>. Acesso em mar. 2017.

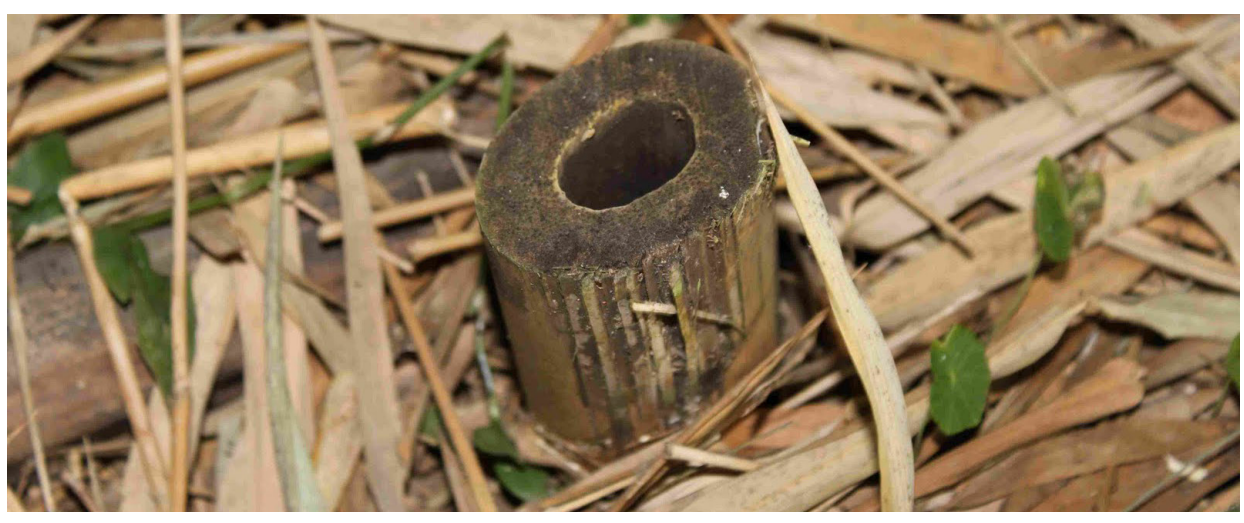

FIGURA 6

Corte incorreto de bambu. Disponível em: <http://ipdtaipal.blogspot.com. br/2011/06/colheita-de-bambus-em-maio-de-2011.html> Acesso em mar. 2017.

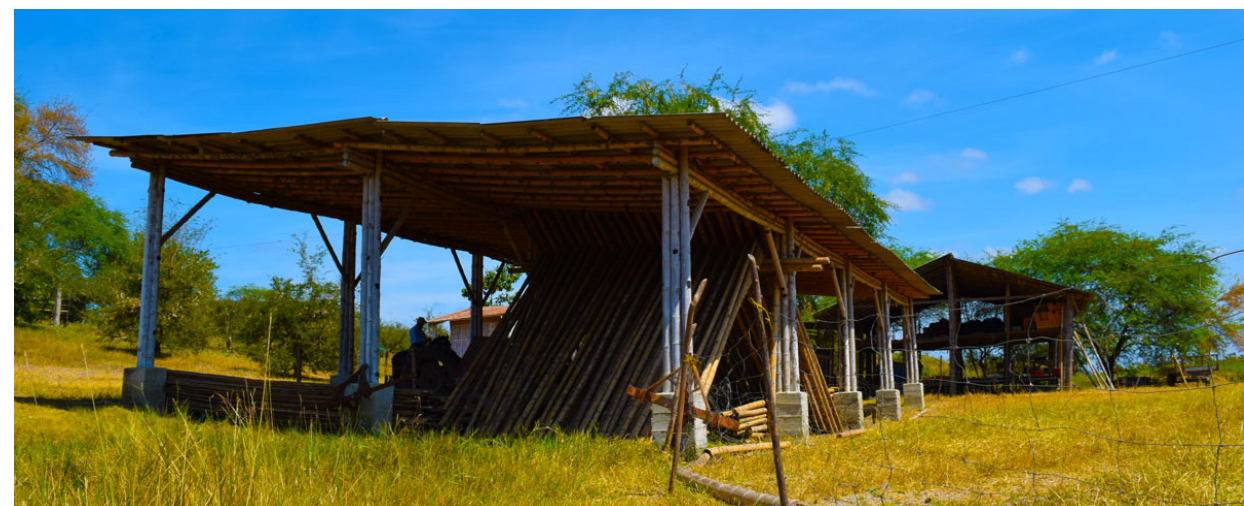

FIGURA 7

Secagem ao ar livre de bambus. Disponível em: <http:// tamarindoorganico. comcana-guadua>. Acesso em mar. 2017. 


\subsection{1}

Ataques à planta

Os agentes biológicos que atacam o bambu, que é parte viva de uma touceira, são diferentes daqueles que atacam bambus já abatidos.

\subsubsection{1}

Ataques a bambus vivos

O bambu pode ser atacado por fungos ou por pequenos insetos que se alimentam do amido contido nas células de parênquima (PEREIRA, BERALDO, 2008).Algumas patologias causadas por esses ataques são solucionadas cortando o bambu afetado ou, simplesmente, aplicando fungicida ou pesticida na área atacada.

Hidalgo-López (2003) relata que os ataques de fungos muitas vezes não mudam consideravelmente as propriedades físicas do bambu, simplesmente variam sua coloração. Aqueles ataques que modificam a estrutura interna dos tecidos do bambu, como insetos xilófagos ou parasitários, inviabilizam a utilização desses colmos uma vez abatidos que são, portanto, descartados.
3.4.1.2

Ataques a bambus abatidos

Se os bambus têm menos de 3 anos quando removidos do bambuzal, serão mais propensos a sofrer ataques. Existe também maior possibilidade de ser atacado quando a umidade no colmo está abaixo do ponto de saturação de fibras (PSF). Esses ataques podem reduzir a durabilidade dos bambus, acelerando a sua deterioração e tornando-os não aptos para suportar esforços requeridos em construções. Segundo Hidalgo-López (2003), os insetos que atacam os bambus não são os mesmo que atacam a madeira.

São mais suscetíveis de ataque, nos extremos secionados dos colmos, nas lesões no córtex e nas cicatrizes das bainhas. Liese (1998) também observa que a base do colmo tem mais durabilidade do que a parte do meio e do topo. O interior do colmo é mais propenso a sofrer ataques devido à grande quantidade de parênquima. Os colmos jovens são mais atacados do que os colmos maduros (Figura 8).

\subsubsection{1 \\ Fungos apodrecedores}

A presença de água nos colmos é essencial para aparição desses mi- crorganismos. O ataque dos fungos ocorre sobretudo quando o teor de umidade está acima do ponto de saturação das fibras, e aparecem quando o bambu se encontra em áreas não ventiladas, em contato direto com o solo, ou expostos à agua de chuva de forma frequente.

O bambu não apodrece quando está completamente submergido na água de forma permanente ou em condições ambientais secas e com umidade nos tecidos abaixo do PSF.

Os fungos de podridão marrom (Figura 9), assim como os brancos, geram mudanças nas propriedades químicas dos tecidos, mas só a podridão marrom reduz a massa do bambu, prejudicando sua resistência mecânica (HIDALGO-LÓPEZ, 2003).

Os fungos do mofo aparecem nos colmos abatidos devido à grande quantidade de amido e de água nas células parenquimáticas, e infestam rapidamente os colmos quando se encontram em ambientes de umidade e temperaturas elevadas.

O mofo é um bom indicador das condições de umidade ambiental, que podem ser sintomáticas, e até mesmo auxiliar na previsão de outros ataques de fungos. $\mathrm{O}$ mofo não destrói tecidos nem diminui a resistência mecânica do bambu, mas pode diminuir a dureza do córtex. 


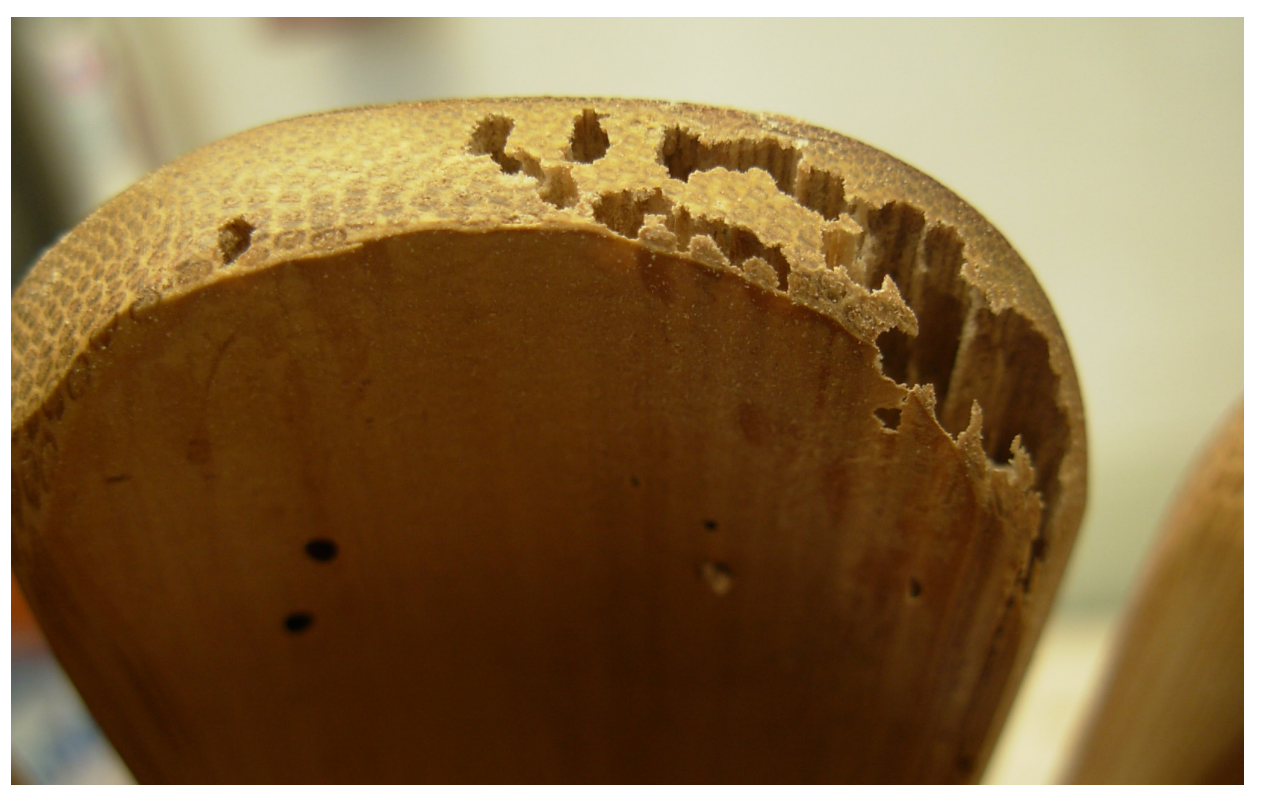

FIGURA 8

Bambu atacado

por insetos xiló-

fagos. Disponível

em: <http://www.

bamboocraft.net/

forums/showthread.

php?t=1324 $>$. Acesso

em mar. 2017.

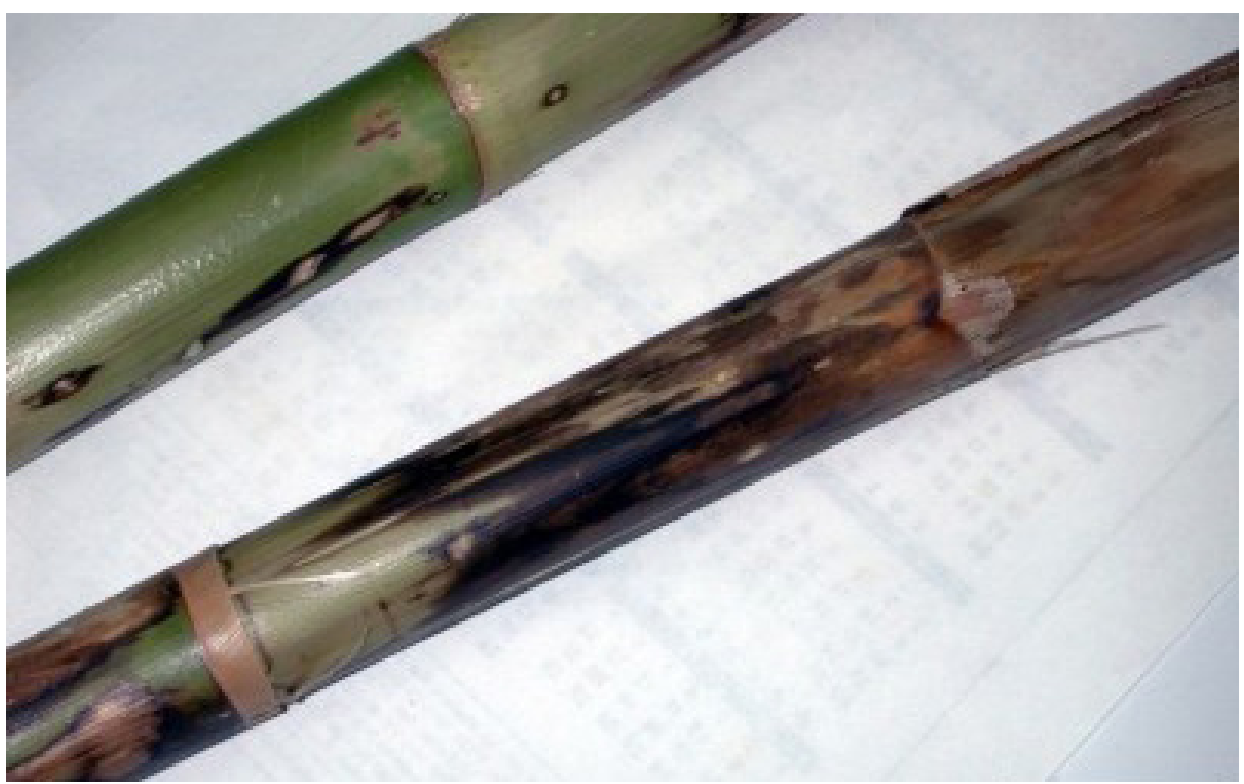

FIGURA 9

Podridão no colmo

de bambu. Dispo-

nível em: <https://

www.gardenin-

gknowhow.com/

ornamental/foliage/

bamboo/bamboo-

-plant-diseases.

htm>. Acesso em

mar. 2017. 
3.4.1.2.2

caruncho

Os insetos atacam as partes internas do bambu onde há mais células de parênquima, que são as células onde se armazena o amido, portanto onde é mais macio e mais fácil de degradar.

O principal inseto xilófago que ataca é o caruncho (Dinoderus minutus), um tipo de inseto coleóptero do tipo xilófago, que perfura a madeira, assim como cupins e vespas.

$\mathrm{O}$ ataque de caruncho começa logo depois do abate. Aqueles bambus cortados durante o verão são mais atacados do que os cortados ao fim da época de chuvas, por causa da concentração elevada de amido (Figura 10). A entrada no bambu se dá pela secão no extremo do colmo, por feridas e rachaduras do córtex ou pela cicatriz dos ramos cortados (SALGADO, 2014).

3.4.1.2.3

Cupim

Cupins são insetos que se alimentam de celulose, constroem um sistema de cavidades nas paredes dos bambus, que os protegem e os alimentam ao mesmo tempo.

O amido é o principal atrativo para esses insetos, quando, ao cria- zindo a massa e, portanto, sua capacidade resistente.

O bambu possui uma concentração muito alta de amido durante a estação seca e, por isso, são mais atacados quando colhidos nessa época do que no fim da estação de chuvas (HIDALGO-LÓPEZ, 2003).

\section{4 .2}

Tratamento preservativos do bambu

Os tratamentos preservativos têm como finalidade única e exclusiva conceder ao bambu certas propriedades químicas que o façam menos atraente a microorganismos ou insetos que têm no amido contido no bambu uma fonte de alimento. Esses agentes biológicos podem modificar a estrutura física do bambu e, de certa forma, consumi-la, prejudicando sua resistência mecânica e comprometendo o desempenho da estrutura. Existe uma relação muito estreita entre a preservação dos tecidos do bambu e a sua durabilidade.

A principal preocupação para a exploração do bambu visando aproveitar todo seu potencial é a baixa durabilidade do material (JANSEN, 2000).

Vale frisar que o bambu, de uma forma geral, tem uma durabilidade ainda menor do que as madeiras.
O vazio dos colmos é uma grande vantagem, mas, ao mesmo tempo, pode-se tornar um grande problema. Os vazios dão ao bambu uma densidade muito baixa, que permite fazer estruturas muito leves, mas essa falta de massa o torna muito mais frágil quando é atacado por insetos que se alimentam dos seus tecidos.

Não há estudos que demonstrem a correlação entre a durabilidade e o momento do abate com respeito à fase lunar, tratando-se mais de uma tradição do que uma realidade física (JANSEN, 2000).

A expectativa de vida de um bambu abatido exposto a intempéries e em contato no solo é de 1 a 2 anos. Quando os colmos estão em ambientes cobertos e sem contato com o solo, prevê-se uma vida útil de 3 a 5 anos. No entanto, quando o bambu está em um ambiente interno e controlado, pode durar de 6 a 8 anos, sendo que, com tratamentos preservativos adequados, pode-se estender para o período de 10 a 15 anos (HIDALGO-LÓPEZ, 2003).

A durabilidade da parte apical dos colmos é maior por conta da maior concentração de fibras e da menor quantidade de feixes vasculares e parênquima, o que torna essa parte menos atraente para os agentes biológicos. 
Hidalgo-López (2003) enumera uma série de regras básicas para a escolha de bambu, visando uma preservação mais duradoura:

1) Escolha de espécies com menor suscetibilidade de serem atacadas por fungos e insetos. Por exemplo, Bambusa vulgaris é conhecida pela alta concentração de amido, o que a torna um alvo muito vulnerável.

2) Colheita dos colmos em épocas adequadas, quando o teor de umidade seja menor ou a quantidade de amido seja mais baixa.

3) Corte correto do bambu para evitar o apodrecimento e deterioração do rizoma, podendo prejudicar o resto do bambuzal.

4) Escolha do colmo a ser abatido de acordo com a idade e com um fim determinado.

5) Escolha do tratamento preservativos adequado para uma utilização permanente.

6) Utilização correta dos bambus com boas práticas construtivas básicas, para um correto desempenho do material.

Uma vez cortado, o bambu está sujeito a mudanças fisiológicas, seja pela exposição direta ao sol, pelas mudanças de umidade ou por causa de agentes biológicos. Após o corte, o bambu deve ser submetido a um tratamento de "cura" para evitar os

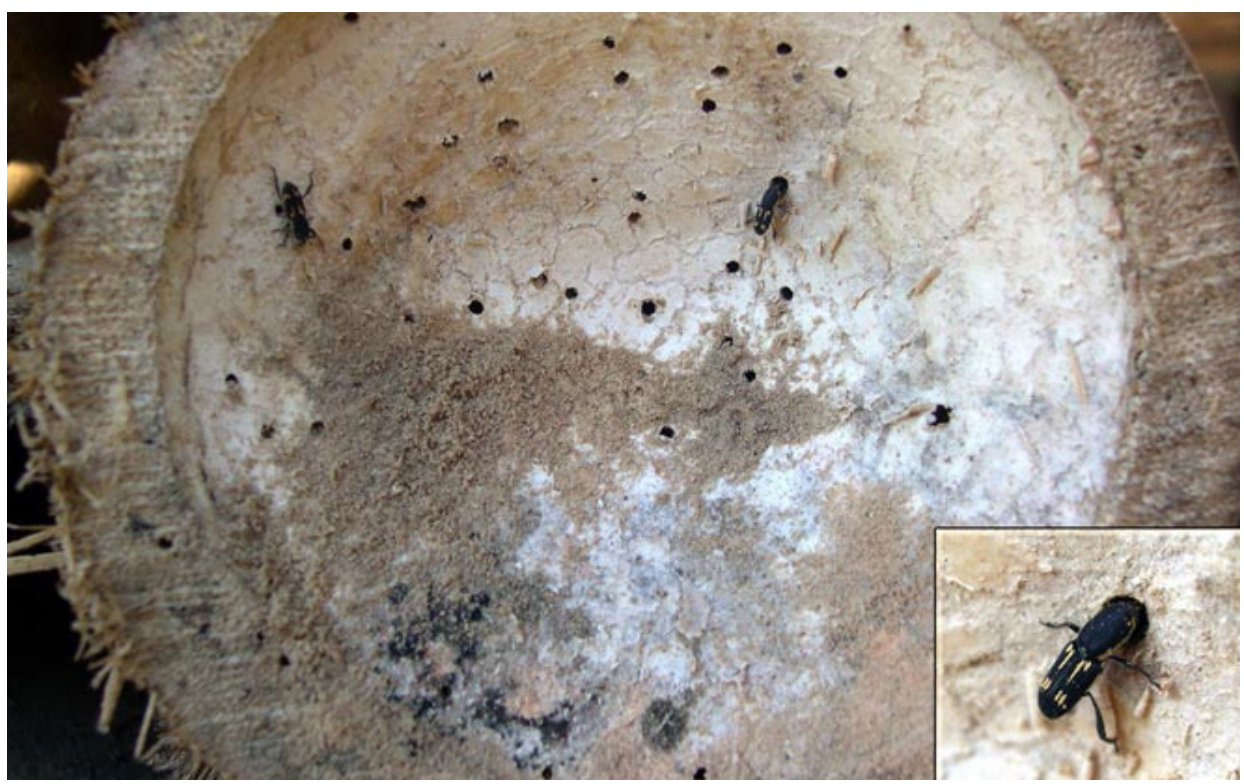

FIGURA 10

Ataque de caruncho à seção de um colmo. Disponível em: <www.guaduabamboo.com>. Acesso em mar. 2017 
ataques de agentes biológicos, atraídos principalmente pelo amido contido no tecido parenquimático.

Há duas grandes famílias de tratamentos para o bambu: a que o submete a processos físicos, e a que o submete a processos químicos.

Os processos físicos consistem em diminuir ao máximo possível a concentração de amido no parênquima e nos feixes vasculares. Os tratamentos químicos consistem em impregnar de substâncias com certa toxicidade as superfícies dos colmos e dos vasos condutores.

3.4.2.1

Tratamentos físicos

São aqueles tratamentos que não modificam as propriedades químicas do bambu.

3.4.2.1.1

Cura na mata

Processo natural no qual se elimina grande parte da seiva contida no colmo e se evita o ataque de agentes biológicos. Uma vez abatidos, os colmos permanecem entre 4 e 8 semanas verticalmente, evitando o contato com o solo e com todos os ramos e folhas, forçando o colmo a manter expulsa, e dessa forma, consumindo o amido. A diminuição lenta da quantidade de seiva evita rachaduras na parede e também conserva a coloração natural externa.

Existem tratamentos mais invasivos para acelerar esse processo de cura, como a secagem por calor para encurtar os tempos da perda de seiva e também para corrigir, durante esse processo, possíveis desvios da linearidade do colmo (Figura 11).

\subsubsection{2 \\ Cura por imersão}

Os colmos recém-cortados são submergidos em água corrente ou estagnada durante um período de 4 a 7 semanas para perder todo o amido (PEREIRA; BERALDO, 2008). Hidalgo-López (2003) destaca que este tratamento consegue prevenir o futuro ataque de caruncho, mas não o de térmitas nem de fungos (Figura 12).

\subsubsection{3 \\ Cura por defumação}

Os bambus são colocados em recipientes fechado e se introduz fumaça da queima de combustíveis. $\mathrm{O}$ calor atua degradando o amido e a água contidos no colmo. Os colmos são expostos à fumaça da queima de combustíveis que depositam resíduos tóxicos nos tecidos. Este sistema faz o bambu resistente ao ataque e à podridão, mas tem um impacto negativo ao meio ambiente.

Existe a opção do cozimento a vapor, que um método muito semelhante à cura por defumação, com a diferença que se introduz vapor no recipiente (Figura 13). O processo não é tão contaminante para o meio ambiente, embora as partículas tóxicas ajudem a deixar os colmos menos atraentes aos insetos (Figura 14).

3.4.2.1.4

Cura por calor

Os bambus são dispostos entre 30 a 40 cm de uma vala com brasas de carvão e são girados para que sejam aquecidas todas as suas partes uniformemente. Uma mudança muito brusca de temperatura pode produzir defeitos nos colmos e rachaduras no córtex. Esse sistema é utilizado também para endireitar ou curvar os colmos.

Outros sistemas destacados por Hidalgo-López (2003) utilizados ao redor do mundo são, por exemplo, a cura por imersão na lama, utilizado em Bangladesh, a cura por imersão na areia de praia, cura por imersão na água do mar utilizada 

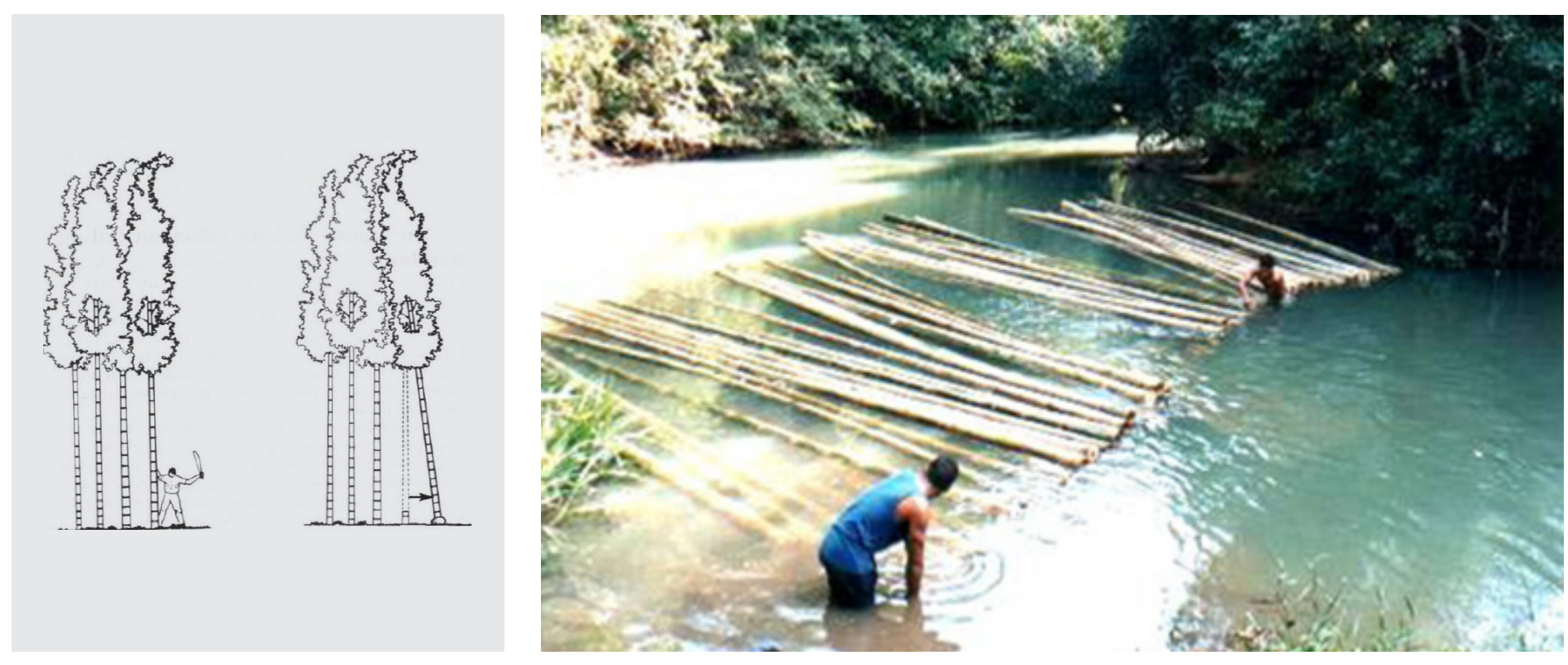

FIGURA 11

Cura na mata. Fonte: HIDALGO-LÓPEZ, 2003.

$>$

\section{FIGURA 12}

Método de cura por imersão. Disponível em: <http://impermeabilizacaoemcasa.blogspot.com. br/201101/bambuna-construcao-civil. $\mathrm{html} />$. Acesso em mar. 2017.
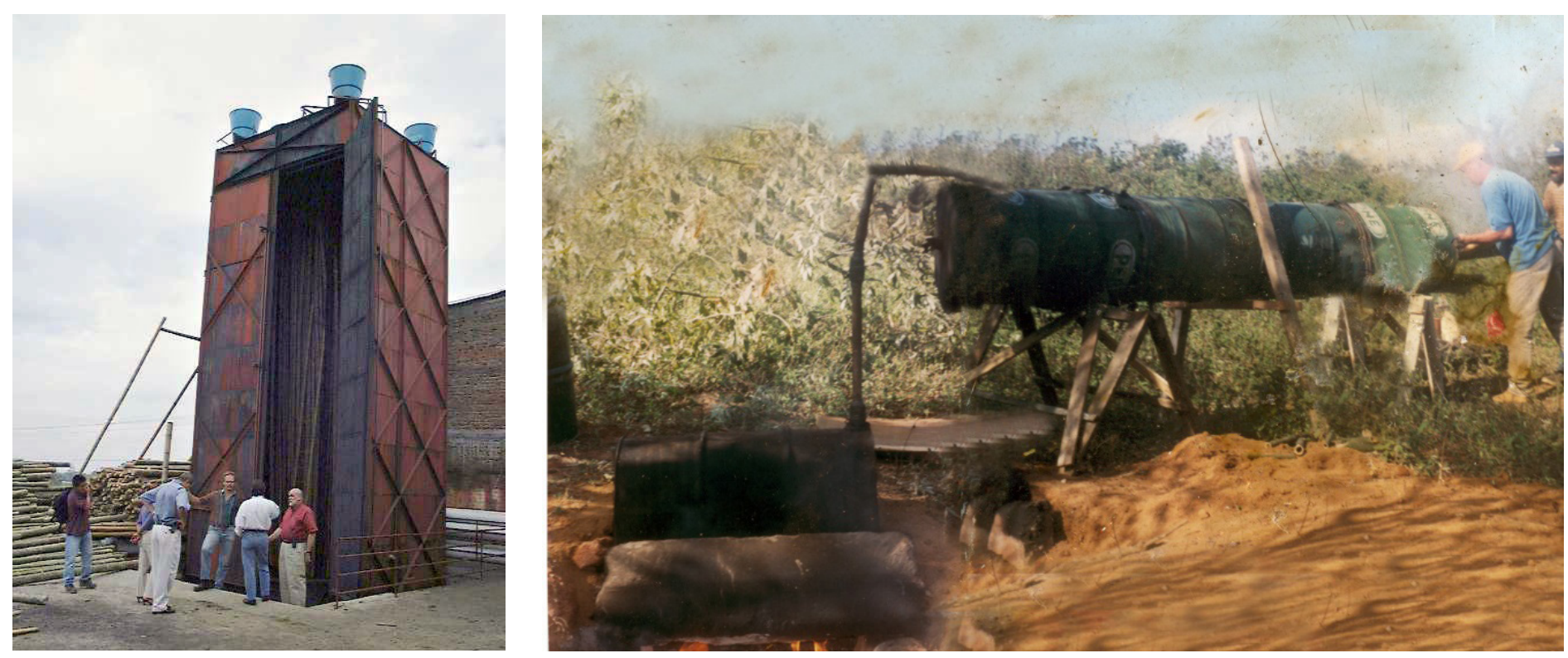

$>$

FIGURA 13

Método de cozimento a vapor. Disponível em: <http://coral. ufsm.br/righiagenteeficientebambu.php >. Acesso em mar. 2017 $<$ FIGURA 14 Sistema de cura por defumação. Foto: Jorg Stamm. Fonte: PEREIRA; BERALDO, 2008. 
em Filipinas e estudada em Cuba, segundo Pereira e Beraldo (2008), a proteção por acabamento superficial de cal $\mathrm{Ca}(\mathrm{OH})_{2}$. No Brasil, utiliza-se o composto chamado calficite, constituído por uma mistura de cal, fibra vegetal, terra e cimento, colocado como revestimento na superfície dos colmos.

3.4.2.2

Tratamentos químicos

A aplicação de substâncias químicas ajuda a conservação e a proteção contra os agentes biológicos que deterioram os tecidos do bambu e que ao longo do tempo podem prejudicar as propriedades e o desempenho mecânico do colmo.

Os produtos devem ser suficientemente ativos para evitar a consolidação e propagação de microrganismos que se alimentam dos compostos químicos presentes nos tecidos do bambu.

Há uma série de princípios descritos por Salgado (2014) que os tratamentos devem cumprir:

1) As substâncias devem garantir a salubridade do ambiente e não serem nocivas ao meio ambiente uma vez aplicadas.

2) As substâncias não devem alterar as propriedades físico-químicas nem mecânicas do material.
3) Para uma correta absorção, as substâncias devem estar em estado líquido.

4) Devem visar o conforto do usuário, portanto não devem ter cheiro forte ou desagradável.

5) Se o bambu vai ser exposto naturalmente no ambiente, não devem alterar significativamente a coloração nem o aspecto do colmo.

Os tratamentos para uma durabilidade maior do bambu são muito diversos; a escolha depende do tempo que se dispõe, dos recursos econômicos, da tecnologia, do uso final do material e da infraestrutura disponível.

Liese (1998) destaca uma série de caraterísticas anatômicas do bambu que limitam a penetração de substâncias profiláticas:

1) A penetração é feita pelos vasos condutores que só ficam disponíveis nas extremidades seccionadas. Dificilmente a substância penetra as paredes internas, ainda menos pelo córtex.

2) Limos e tilose são produzidos pelo bambu naturalmente após uma lesão nos tecidos contíguos aos vasos. Essas substâncias reduzem o diâmetro dos vasos reduzindo o fluxo em seu interior.

3) Ausência de vasos dispostos radialmente ou tangencialmente no tecido do bambu, portanto, a penetração por difusão nos tecidos é muito lenta.
4) A camada quase impermeável do córtex impossibilita a absorção de tratamento pelas faces externas do bambu.

Ao haver uma alta concentração de fibras no córtex, as substâncias preservantes serão mais difíceis de penetrar, portanto, sempre são aplicados os tratamentos de dentro para fora das paredes do bambu. Os vasos condutores, são maiores e em maior quantidade no interior da parede do colmo. Isso revela uma fragilidade do bambu: qualquer defeito no córtex supõe uma possível porta de acesso a qualquer ataque biológico, isso inclui a seção na extremidade do colmo, na qual se expõem claramente os tecidos parenquimáticos e os vasos condutores, tornando-o o ponto fraco e onde se deve ter mais atenção na proteção.

3.4.2.2.1

Aproveitamento da transpiração

Tratamento semelhante à cura na mata, coloca-se o colmo recém-cortado num recipiente com a solução preservativa e o conservante vai ser conduzido pelos vasos pela corrente transpiratória natural originada pelas folhas. Ao estar o organismo e as células vivas, o conservante vai penetrar de forma natural em todos os tecidos, tornando o tratamento muito efetivo, porém muito mais lento. 
Para Liese (1998), esse é método mais efetivo (Figura 15).

\subsubsection{2}

\section{Boucherie}

Tratamento realizado em colmos recém-cortados, aplica-se a substância pela extremidade do colmo por pressão hidrostática, expulsando a seiva e ocupando o espaço pelo conservante. Engata-se numa extremidade do colmo um cilindro de borracha conectado a uma tubulação controlada por uma válvula, que conduz a solução preservativa desde o reservatório posicionado relativamente acima dos colmos até um recipiente coletor situado na outra extremidade do colmo. Os colmos precisam estar em posição vertical ou inclinados para a efetividade do tratamento (Figura 16).

As principais dificuldades encontram-se na dificuldade de se realizar os engates, devido à variabilidade geométrica da seção dos colmos (Figura 17).

\subsubsection{3}

Boucherie modificado

Processo muito semelhante ao do sistema Boucherie, mas a injeção de conservante se dá por de pressão pneumática graças a um compressor. Esse método é um dos mais utiliza-

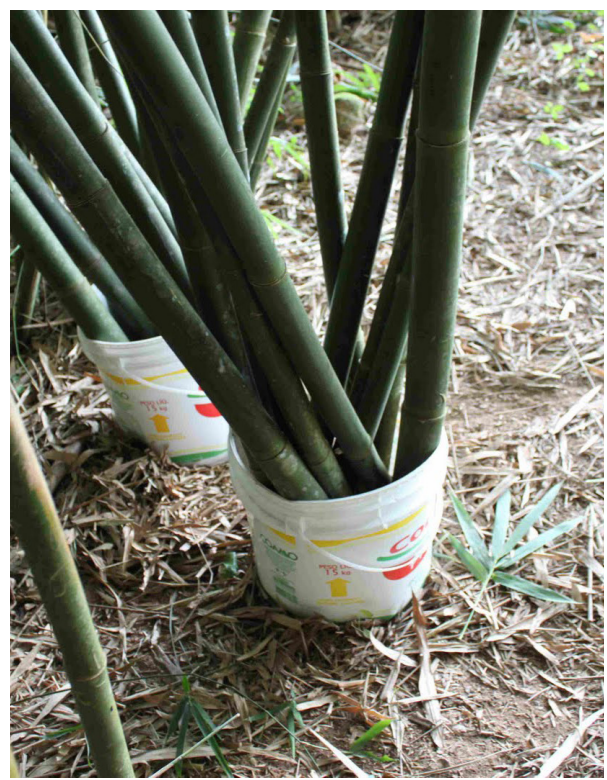

FIGURA 15

Método de aproveitamento por transpiração. Disponível em: <http://ipdtaipal.blogspot.com. br/2011/06/colheita-de-bambus-em-maio-de-2011.html>. Acesso em mar. 2017.

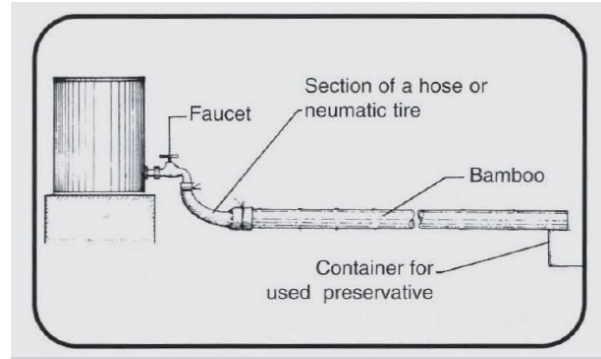

FIGURA 16

Esquema do sistema Boucherie. Fonte: HIDALGO-LÓPEZ, 2003.

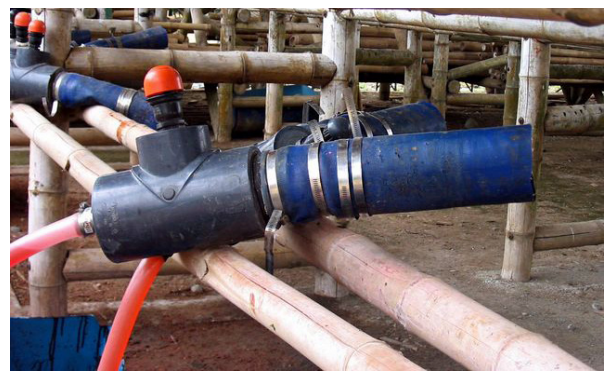

FIGURA 17

Engate do sistema Boucherie. Fonte: PEREIRA; BERALDO, 2008. 


\section{FIGURA 18}

Esquema do sistema boucherie modificado. Fonte: HIDALGOLÓPEZ, 2003.

\section{FIGURA 19}

Tratamento por imersão. Fonte: PEREIRA, BERALDO, 2008.

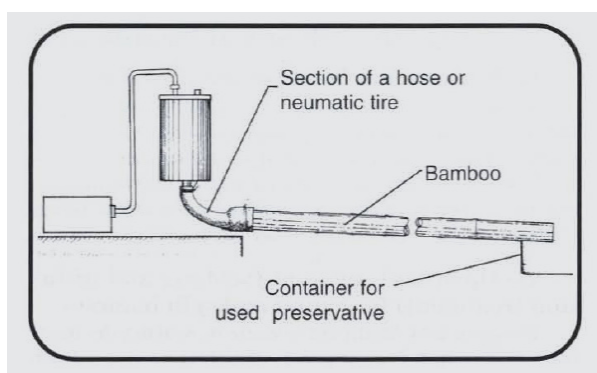

dos na Colômbia, pela sua eficiência e velocidade de penetração dos produtos (Figura 18).

\subsubsection{4 \\ Tratamento por imersão}

Coloca-se o bambu completamente submerso em um tanque ou recipiente com líquido preservativo. Quanto mais tempo o bambu for deixado, mais absorvido o conservante e, em decorrência, mais eficiência do processo. É necessário fazer perfurações nos diafragmas dos bambus para facilitar a impregnação da solução ao maior número de tecidos e isso inclui as partes internas dos internós. É necessário não danificar muito os diafragmas, porque poderia causar falhas no comportamento estrutural do colmo.

Esse tratamento, muito difundido no Brasil, é muito lento, tanto pela absorção das substâncias nos vasos, como para a posterior secagem para eliminar o excesso de água, que é parte da solução preservativa (Figura 19).

\subsubsection{5}

Banho quente-frio

Processo semelhante ao tratamento por imersão, mas em duas fases. A primeira fase é constituída pelo mergulho de uma hora com o líquido a $93^{\circ} \mathrm{C}$; na segunda fase, mergulha-se os colmos durante $12 \mathrm{~h}$ com a solução preservativa à temperatura ambiente. Feito com soluções de base oleosa (SALGADO, 2014).

\subsubsection{6}

Aplicação externa

Tratamento superficial do bambu, com uma efetividade muito baixa, não penetra nos tecidos, só protege a camada externa, que por si é a parte mais resistente aos ataques.

\subsubsection{7 \\ Por injeção nos colmos}

Injeção do preservativo no colmo por meio de pulverizador através de furos realizados nos nós do colmo. Tratamento não recomendável devido às lesões necessárias produzidas no córtex e pela pouca penetração nos tecidos.

\subsubsection{8}

Autoclave

Talvez um dos tratamentos mais efetivos, por ser um sistema muito aprimorado pelo extenso uso na indústria madeireira. Os colmos são colocados com os diafragmas perfurados, com um teor de umidade por volta do PSF, dentro do recipiente geralmente ci- 
líndrico que se fecha hermeticamente com controle de temperatura e de pressurização. A solução preservativa penetra por pressão nos tecidos do bambu de forma eficiente(Figura 20).

3.4.2.2.9

Produtos utilizados

Existem dois tipos de soluções com bases completamente diferentes. Os que são à base de óleos e os que são à base de sais. Os oleosos como o creosoto, o pentaclorofenol, o naftenato de cobre e o neutrol, entre outros, são substâncias altamente tóxicas para os agentes biológicos, insolúveis na água, com cor escura - e, portanto, modificam a aparência natural do bambu - têm baixa volatilidade, não permitem a aplicação superficial de outras soluções, possuem cheiro desagradável, são inflamáveis e têm fácil aplicação. São recomendados para bambus com contato com água (SALGADO, 2014).

Os tratamentos que são feitos com essas substâncias demandam que os bambus estejam secos.

Os sais são solúveis em água, sem cheiro desagradável, permitem a aplicação superficial de outros tratamentos, e não se recomenda o contato do bambu com a água. São utilizados o cromato de zinco, cromato de boro e demais sais à base de boro. As soluções aquosas penetram no bambu e reagem com a lignina das paredes celulares produzindo compostos insolúveis. Não são tóxicos para os humanos.

O octaborato de sódio é um dos sais mais frequentemente utilizados como tratamento. Possui uma ação residual intensa, baixa toxicidade para pessoas e animais, sem cheiro e não se descompõe ao longo do tempo pelo fato de ser inorgânico (SALGADO, 2014).

O octaborato de sódio é constituído por uma mistura de bórax ou ácido bórico, tratando-se de um produto menos agressivo para o meio ambiente,.Pode ser utilizado mais de uma vez, e só deve ser descartado quando a concentração de seiva na solução já seja muito elevada.

Os descartes dos tratamentos à base de sais não são excessivamente tóxicos ao meio ambiente por possuírem um conteúdo altamente salino e, portanto, absorvível pelo solo em pequenas quantidades. Assim, evita-se poluir o lençol freático. Diminuindo a concentração, isto é, aumentando a proporção de água, pode ser utilizado como herbicida em outros plantios (SALGADO, 2014).

Outros tratamentos com substâncias com nanopartículas de prata, estudados por Barbosa e Pandoli (2015), têm demonstrado sua efetividade na prevenção da aparição de fungos, mas não têm sido testados em bambus utilizados estruturalmente.

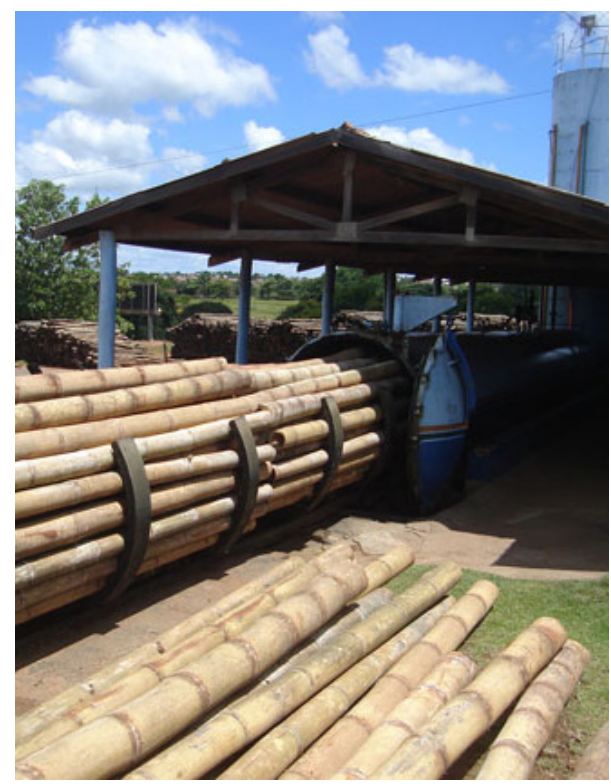

FIGURA 20

Tratamento por autoclave. Disponível em: <http://www. casaebambu.com/ tratamento-de-bambu>. Acesso em mar. 2017. 


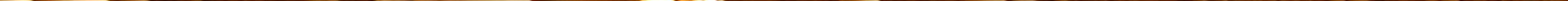




\section{Capítulo 4 \\ Construção estrutural \\ com bambu}

O bambu é um material com um potencial excelente para a conformação de muitas das partes funcionais de um edifício. Sobretudo devido às suas capacidades mecânicas para exercer a função estrutural, que, entre todos, é o setor mais oneroso de uma construção.

Existe uma correlação geográfica entre regiões do planeta onde há um crescimento natural da planta abundante e nativo e regiões do planeta com níveis de pobreza mais elevados. Essas regiões desfavorecidas apresentam índices de déficit de habitação muito elevados, portanto, o uso de um material tão fácil de ser encontrado e com custos tão baixos ajudaria a amenizar esses problemas no curto prazo.

Por outro lado, a situação ecológica do planeta está chegando a pontos insustentáveis, e seria interessante que, no médio prazo, os países desenvolvidos responsáveis pelo consumo da maioria dos recursos globais, começassem a utilizar recursos como o bambu em substituição aos materiais conven- cionais para estruturas, como são o aço e o concreto, já que estes possuem uma pegada ecológica muito prejudicial.

Hoje em dia nos países asiáticos há um uso muito estendido do bambu em estruturas temporárias suplementares na construção civil, como andaimes e escoras. $\mathrm{O}$ fato de não existir o requisito de uma durabilidade extensa no desempenho do material faz dele ideal para estruturas efêmeras (Figura 1).

Gernot Minke (2010) descreve quais são, as vantagens e desvantagens de se trabalhar com bambu em uma construção. É necessário analisar as desvantagens, trabalhar para mitigá-las a fim de ir ganhando cotas de mercado e quebrar certos paradigmas no uso dos materiais não convencionais.

Vantagens da construção em bambu:

- Material muito leve com resistência mecânica muito alta;

- Camada externa do bambu com valores de resistência à tração 
axial semelhantes aos do aço;

- Crescimento muito rápido da planta;

- Pegada ambiental muito baixa. Desvantagens:

- Comportamento estrutural muito variável entre espécies, condições de crescimento, idade, teor de umidade e região do colmo. Isso dificulta a normatização e o estabelecimento de critérios generalizados para a utilização do material em grande escala e com segurança. Na Colômbia, a norma de construção com bambu é somente para a espécie $G$. angustifolia, limitando-se, a uma única espécie, pois precisam fazer testes para analisar as propriedades dos bambus crescidos em diferentes localizações e condições;

- Material muito vulnerável à radiação solar e à água, requer proteção constante;

- Material muito atrativo para alguns agentes biológicos pelo ele- vado teor de amido nos tecidos;

- Baixa resistência a esforços de tração perpendicular às fibras, principalmente na direção tangencial, o que faz dele muito pouco resistente ao fendilhamento;

- A geometria roliça tão caraterística, e com um apelo estético tão potente, se torna um problema na hora de ser trabalhado e ser utilizado na estrutura, para encaixar com outros materiais de linhas mais retas; a geometria irregular não aparente, como as diferenças no diâmetro do colmo, na espessura da parede e na distância entre os nós ao longo do colmo;

- Crescimento não perfeitamente retilíneo;

- O córtex é tão resistente que não pode ser trabalhado com ferramentas típicas para madeira, pois pode facilmente danificá-las;

- Ausência de normativa consolidada que guie profissionais e dê segurança aos construtores e usuários.

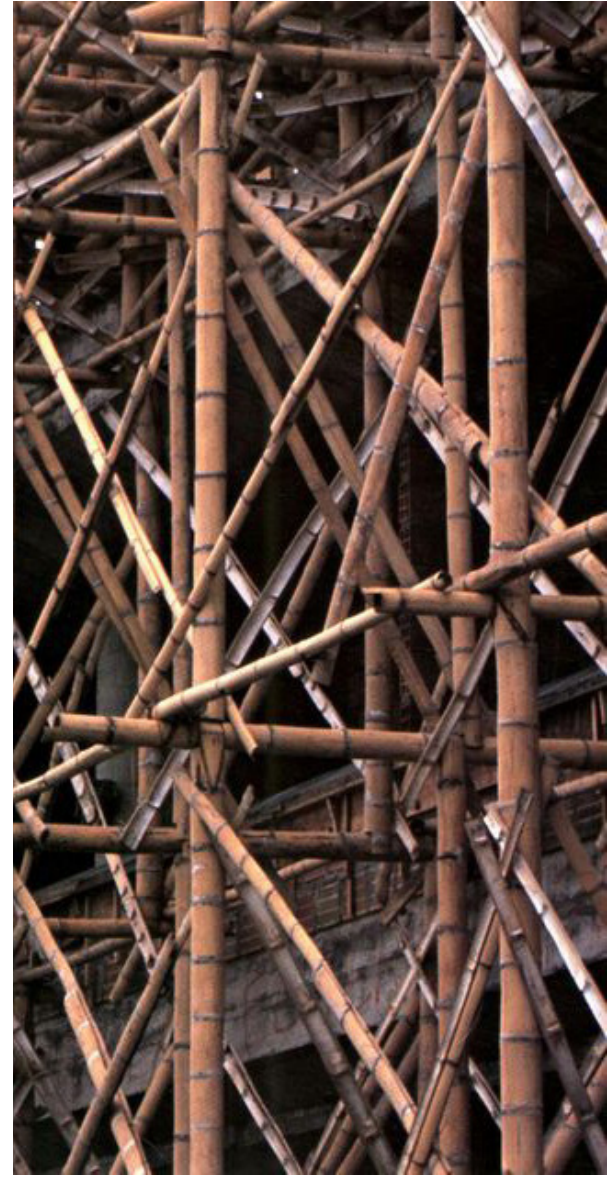

FIGURA 1

Andaime de bambu na Ásia. Fonte: PEREIRA; BERALDO 2008. 
Gernot Minke, citado por Frey e Von Schaewen (2013), tem a impressão, com base nos seus estudos, que as técnicas tradicionais para se trabalhar com bambu não oferecem estabilidade nem um controle preciso dos colmos para garantir uma distribuição ótima das cargas, que permitiria ao material ser parte de um sistema estático, complexo, sólido e confiável.

A anisotropia do bambu e os seus bons atributos, porém inconstantes, convertem sua utilização em um tipo de especulação projetual em que, com base em certos princípios construtivos, implementam-se soluções arriscadas que, quando não demonstram um desempenho adequado, dizimam a reputação e credibilidade do material.

Para Pereira e Beraldo (2008), o uso estrutural do bambu não é utilizado na plenitude do seu potencial por causa da deficiência de equipamentos especializados e pela mão de obra pouco experiente em relação ao material.

Os arquitetos Marcelo Villegas e Simón Vélez conseguiram, ao longo de extensa carreira como construtores, harmonizar os princípios estruturais de uma arquitetura moderna com a potencialidade mecânica do bambu. Partindo de uma tradição vernacular de conexões e métodos construtivos muito primitivos e rús- testes e correções in loco, conseguiram aperfeiçoar as técnicas antigas, aliando-as a materiais novos, como o aço e o concreto (Figura 2).

O conceito "nova arquitetura vernacular” é descrito por Frey (2010) como aquela arquitetura que toma a cultura tradicional e os materiais encontrados nas artes de construção e os fertiliza com a competência e a criatividade dos profissionais formados em escolas de arquitetura e engenharia ao redor do mundo, mas sem subordinar essas culturas aos imperativos do mercado global de materiais de construção (concreto, aço, vidro, entre outros). A ideia é usar materiais brutos com pouco valor agregado, como o bambu.

No design estrutural com bambu, é importante que haja uma correlação entre as propriedades dos elementos estruturais da construção e o tipo de carga que cada um dos elementos pode suportar de maneira eficiente. Os tipos de tensões que podem haver em elementos estruturais de bambus são originados por esforços axiais (tração e compressão dependendo da direção), esforços transversais (tração e compressão dependendo da direção), flexão estática e torção (ARCE, 1993).

Uma das grandes questões na hora de se trabalhar e estudar o bambu é o fato de não poder se aproveitar da sua enorme capacidade resistente à tração paralela às fibras do material, e isso se deve ao fato de não existirem mecanismos nem elementos com uma boa fixação ao colmo, ou seja, que fixem bem o colmo sem deteriorá-lo, esmagá-lo ou produzir fendas.

A investigação de mecanismos que melhorem o desempenho de conexões para tracionar o bambu é um requisito indispensável para que esse material continue conquistando terreno na construção civil e mais concretamente nas estruturas espaciais leves.

\section{1 \\ Sistemas estruturais}

Estrutura é um conjunto de elementos que se inter-relacionam para desempenhar uma função: criar um espaço em que as pessoas exercerão diversas atividades.

Para entender o comportamento das estruturas é preciso partir da observação do comportamento mesmo da natureza, pois ela tende a resolver seus problemas de ordens biológica e física de maneira mais simples, econômica e bela (RABELLO, 2000), ou, como outros autores afirmam, são estruturas funcionalmente graduadas.

O papel da estrutura na arquitetura, segundo Engel (2001), se define por estes princípios: 
1) A estrutura é a primeiro e único instrumento para gerar forma e espaço na arquitetura. A estrutura modela o espaço do homem;

2) A estrutura se sustenta nos princípios e leis naturais da gravidade; em decorrência, o projeto tomará como norma absoluta as forças que formam as linhas estruturais;

3) A relação arquitetura-estrutura proporciona um espaço infinito de atuação, e pode ser a parte visível ou invisível da construção;

4) A estrutura é a tentativa criativa do projetista de unificar forma, material e forças.

O conjunto de elementos que forma uma estrutura estão predispostos para serem o caminho pelo qual as forças que atuam sobre ela devam transitar até chegar ao seu destino final. Essas forças que atuam na estrutura arquitetônica podem ser de origem gravitacional, por ação do vento ou por movimentações sísmicas. Elas sempre tendem a buscar o caminho mais curto para serem transmitidas até o solo (RABELLO, 2000).

Henio Engel (2001) cria uma catalogação de tipologias estruturais muito extensa para aproximar o mundo da arquitetura ao da engenheira de estruturas. Dessa catalogação surgem seis grandes grupos: sistemas estruturais de forma-ativa,

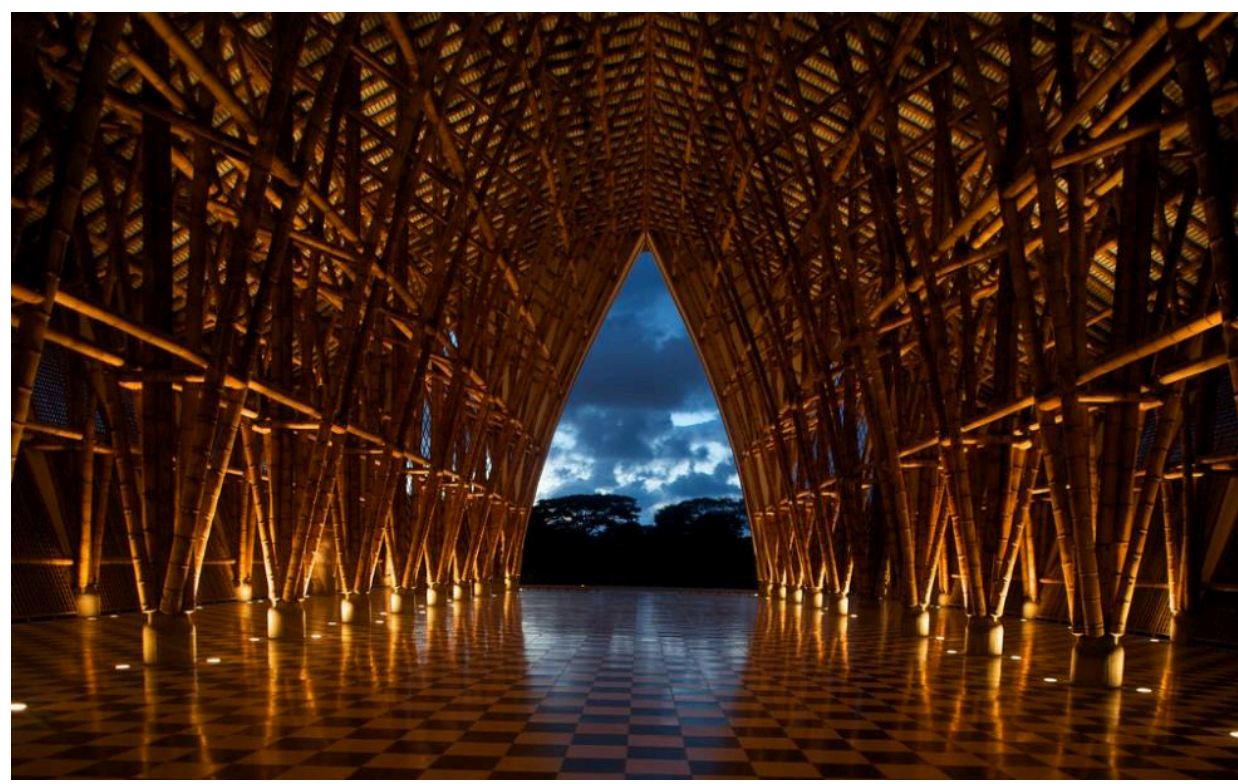

FIGURA 2

Catedral Alterna de Pereira, obra de Villegas e Vélez. Foto: BBC Worldservice. 
de vetor-ativo, seção-ativa, superfície-ativa, altura-ativa e híbridos.

Os sistemas estruturais de vetor-ativo são gerados a partir de componentes lineares curtos, sólidos e retos. Devido à sua pequena seção em relação ao seu comprimento, podem transmitir esforços na direção do seu comprimento, esforços axiais de compressão e tração, exatamente como se dão as estruturas de bambu.

As barras devem ter uma montagem criando relações triangulares entre si para evitar as deformações nas conexões, que, a princípio, serão articuladas para evitar momentos nas barras. A incorporação dessas associações triangulares pode vencer grandes vãos com uma economia de material muito grande.

As diferentes associações dessas peças criam quatro grandes grupos estruturais de vetor-ativo (Figura 3):

- Treliças planas

- Treliças planas combinadas

- Treliças curvas

- Treliças espaciais

Observando a maioria dos exemplos de construções realizadas, podese interpretar que, em geral, as estruturas de bambu são de vetor-ativo (Figura 4), porém há casos em que é possível considerar que as estruturas são híbridas, pois, pela agregação mados elementos estruturais que são parte de outros grupos. Por exemplo, quando se juntam vários colmos para aumentar a altura estrutural da viga, pode-se considerar que é híbrido entre um sistema de vetor-ativo e um de seção-ativa (Figura 5).

Muitos arquitetos tentam comumente extrapolar as tipologias estruturais conseguidas com os materiais mais convencionais para as estruturas com bambu, mas este é um material relativamente novo e precisa que se reformulem os arquétipos estruturais consolidados na tradição modernista, para, dessa forma, criar os seus próprios modelos estruturais.

Arce (1996) observa, pelo trabalho de Dunkelberg (1985), que as melhores aplicações estruturais do bambu são para formação de tesouras, treliças ou treliças espaciais, grupo de estruturas denominadas como de vetor-ativo por Engel (2001).

\subsection{Elementos construtivos das estruturas}

Existem então duas grandes categorias básicas de componentes para a materialização de uma estrutura: o elemento portante e o vínculo.

O elemento portante é o bambu em si, é a parte da estrutura com maior presença espacial e a que suporta a maioria das cargas, é o que a priori vai dar expressão formal à construção. $\mathrm{O}$ vínculo é o que é chamado de conexão, a parte da estrutura que transmite as cargas de um vetor para outro vetor, ou no caso de estruturas de bambu, de um colmo para outro colmo.

\section{2 .1}

\section{Colmos}

Os colmos de bambu são elementos naturais com uma excelente resistência à compressão e à tração paralela às fibras. Por isso, o requisito essencial de um colmo que faz parte de uma estrutura (de vetor-ativo) é que as cargas que o tensionam não lhe façam suportar esforços além da compressão ou de tração paralela às fibras.

A resistência mecànica vê-se diminuída relativamente na região do nó, ainda assim, em termos gerais, o colmo continua apresentando valores de tensão de ruptura bem maior que qualquer outro valor obtido em testes de esforço de outras direções.

Pode-se afirmar que essa descontinuidade que representa o nó é um acontecimento diferencial que prejudica relativamente o desempenho em esforços de tração-compressão na direçao paralela às fibras do colmo.

O bambu apresenta também boa resposta aos esforços de flexão. Ape- 


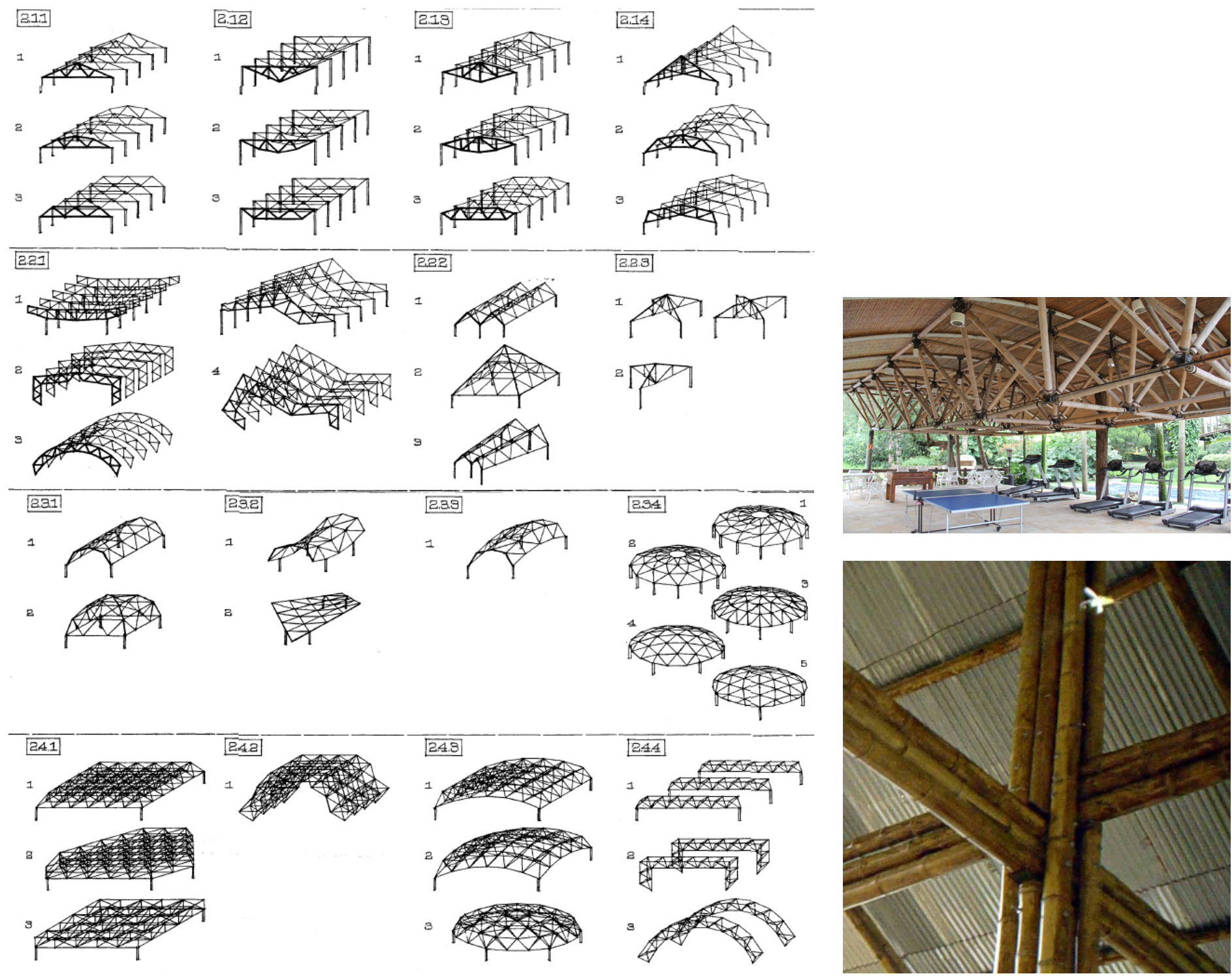

FIGURA 3

Tipologias estruturais de vetor-ativo. 2.1.

Treliças planas:

2.2. treliças planas

combinadas; 2.3

treliças curvas; 2.4

treliças espaciais.

Fonte: ENGEL, 2001.

FIGURA 4

Treliça espacial do

Pavilhão Amana

Key, realizado pelo escritório Amima

Arquitetura. Foto:

Joan Font.

FIGURA 5

Detalhe de estrutura híbrida seção-ativa e vetor-ativo. Fonte: PEREIRA, BERALDO, 2008. 
sar da resistência alta nessa solicitação, os colmos geralemente apresentam flechas muito grandes que não são admissíveis para estruturas em que não são toleráveis deformações que possam influir em outros componentes da arquitetura ou até na percepção de estabilidade por parte do usuário.

Os esforços com pior resposta do bambu são aqueles exercidos transversalmente ao colmo, como a tração e a compressão normal às fibras. A tensão suportada no esforço de tração perpendicular ao eixo longitudinal do colmo de bambu é aproximadamente 50 vezes inferior ao de tração axial, mas o mais curioso é a resposta do teste na área do nó onde a resistência aumenta. Apesar de se apresentarem como uma descontinuidade das fibras e de diminuírem a resistência de alguns esforços, os nós conferem ao colmo certa estabilidade estrutural e certa resistência aos esforços que são perpendiculares ao eixo longitudinal do colmo. Essa caraterística determinará muitas regras normativas e da construção tradicional nas quais se estabelecem condições para forçar o posicionamento (quando for possível) de nós em posições críticas, como quando existem cargas concentradas.

Muitos dos valores das tensões últimas de colmos de bambus são obtidos em ensaios feitos individualmente, não podendo ser aplicados num conjunto estrutural que trabalha solidariamente e que deve atender a uma série de requisitos de segurança e estandardização. Eis que aparecem certos coeficientes de segurança que assumem que esse material apresenta comportamentos por vezes imprevisíveis e irregulares, ao passo que existem muitos fatores durante o crescimento, manejo e processamento que influenciam na qualidade e nas propriedades finais. Entre eles estão sua origem geográfica do colmo, a idade, a parte de onde a peça provém (base, meio, ponta), teor de umidade no colmo, método de tratamento preservativo, entre outros vistos em capítulos anteriores.

\subsubsection{1 \\ Qualidade dos colmos}

Os condicionantes do crescimento in natura do bambu obrigam a propor critérios de seleção de colmos que garantirão sua aptidão para formar parte de um sistema estrutural. Minke (2010) lista os seguintes entre outros pré-requisitos:

- Utilizar colmos maduros, ou seja, que já tenham as características mecânicas consolidadas e otimizadas - acima de 3 anos de idade;

- Não utilizar bambu danificado, com rachaduras ou outras lesões;
- Usar colmos sem excentricidade. A transmissão dos esforços pode ter comportamentos não esperados e gerar tensões residuais capazes de comprometer a estabilidade estrutural do elemento e do conjunto;

- Não utilizar colmos que tenham sido atacados por agentes biológicos;

- Para pilares, utilizar preferentemente a base dos colmos, pois se trata da parte que naturalmente foi mais solicitada a esforços de compressão, pois suporta o peso inteiro do próprio colmo;

- A conicidade dos colmos utilizados não pode ser maior do que 1\%;

- Utilizar colmos com teor de umidade (TU) inferior a $20 \%$, ou seja, abaixo do ponto de saturação de fibras (PSF);

- Não usar colmos verdes sem ter passado por um processo de secagem para não sofrer contração uma vez colocado em obra;

- Não usar colmos que tenham sofrido processos de floração;

- Bambus com paredes muito delgadas;

- Bambus curvos não são aptos para vigas ou pilares, mas podem se utilizar segmentos dele com desvios toleráveis para um melhor aproveitamento do material;

- Se precisar dobrar os colmos deve-se aquecê-los até $120-150{ }^{\circ} \mathrm{C}$ e com um aumento de umidade. 
Janssen (2000) estabelece algumas regras fundamentais para a durabilidade dos colmos:

1) Colheita quando o teor de amido for menor. Depende da estação do ano, de preferência antes de chuvas;

2) Seleção das espécies locais mais adequadas para o propósito;

3) Estocagem dos colmos em local adequado, coberto, arejado e sem contato direto com o solo natural;

4) Transporte marítimo só após tratamento químico.

\subsubsection{2 \\ Princípios de utilização}

- Evitar a aplicação de esforços nos colmos pelos quais o bambu não está preparado, como tração e compressão perpendicular ao eixo axial do colmo;

- Contato do bambu com o solo, condições climáticas ruins, raios ultravioletas, insetos;

- As qualidades teóricas do material não são otimizadas quando o bambu é colocado em obra.

\subsubsection{3 \\ cortes}

Os cortes são modificações nos colmos para melhorar a conectividade de uns com a outros, a fim de trans- mitir os esforços da maneira mais eficiente possível.

Algumas das conexões são idealizadas basicamente pela emenda precisa entre bambus com determinados cortes; então o corte é um processamento do colmo para um bom encaixe no conjunto.

Deve-se cortar os bambus secos,. Quando o bambu é cortado contendo um alto teor de umidade, podem ser produzidas rachaduras, e as fibras podem desagregar, ficando uma superfície de seção desfiada, prejudicando o córtex. Uma vez cortados, é bom regularizar as bordas e preparar um bom encaixe com o colmo ao qual será conectado.

Segundo Janssen (2000), o córtex contém uma quantidade considerável de sílica que protege a planta das agressões externas. Essa condição pode supor uma dificuldade para os trabalhos com determinadas ferramentas utilizadas no manejo, chegando a danificá-las. Devido a essa condição, as ferramentas de corte são as mesmas utilizadas para metal, ferramentas e equipamentos de alta velocidade e de baixa pressão para evitar que as bordas rachem e desfibrem.

Hidalgo-López (2003) catalogou os tipos de cortes em seu manual de construção com bambu (Figuras 6 a 13). 
FIGURA 6

Corte reto.

FIGURA 7

Corte com uma orelha.

\section{FIGURA 8}

Corte com duas

orelhas.

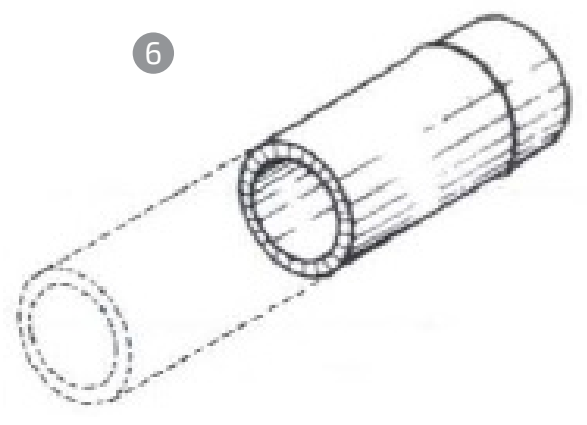

FIGURA 9

Corte diagonal.

FIGURA 10

Corte boca de flauta.

\section{FIGURA 11}

Corte boca de peixe.

\section{FIGURA 12}

Corte de meio bambu.

\section{FIGURA 13}

Corte de meio bambu oblíquo.

\section{FIGURAS DE 6 A 13}

Fonte: HIDALGO-LÓ-

PEZ, 2003.

9

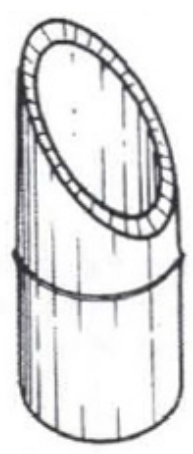

12

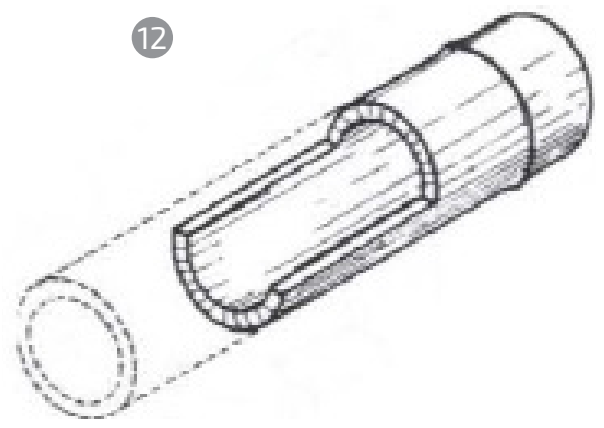

(7)

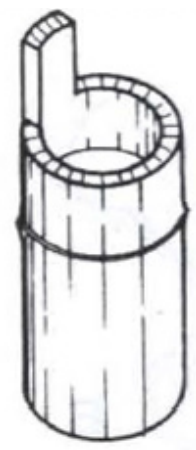

8

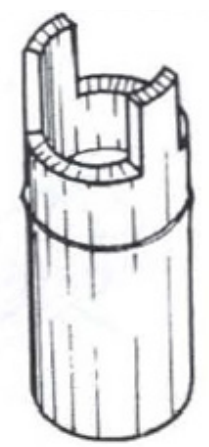

10

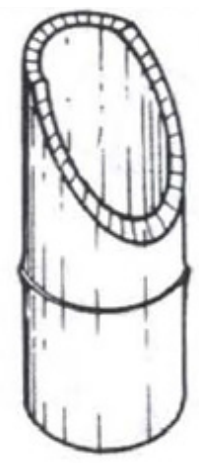

(11)

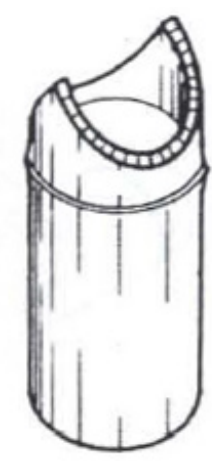

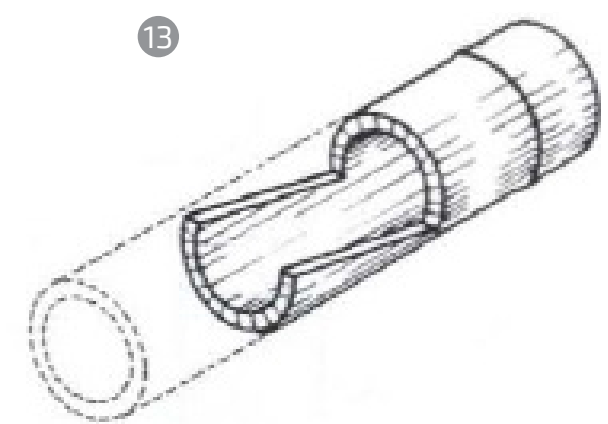




\subsection{2}

Conexões

Assumindo que os colmos de bambu têm excelentes propriedades mecânicas, com determinadas restrições, é função das conexões assumir e redistribuir todas aquelas tensões que os colmos não são capazes de suportar. Tensões como trações e compressões perpendiculares à fibra, cisalhamentos paralelos e todos aqueles esforços que submetam a matriz esclerenquimática dos tecidos dos bambus a tensões pelas quais não estão naturalmente preparados.

Para Minke (2010), a chave da construção de estruturas de bambu reside na correta criação das uniões que transmitam os esforços de um colmo a outro com a direção, sentido e intensidade prevista. Isso, em grande medida, determinará o bom desempenho do sistema.

Ao longo da história, muitos povos das regiões tropicais ou da Ásia desenvolveram soluções construtivas para uniões de bambu. Essas uniões foram elaboradas com técnicas de amarração com fibras naturais.

Em construções formais de porte médio, os amarrações não produzem a rigidez suficiente na conexão e, por essa razão, técnicas alternativas complementares são necessárias (ARCE,
1993). Dessa necessidade surge a evolução construtiva das técnicas de conexões com bambu utilizando elementos complementares, como cavilhas, tarugos de madeira, parafusos entre outros materiais, que ajudam a resolver as limitações que o material apresenta.

\subsubsection{1}

Condicionantes para o design de conexões

Arce (1993) descreve que a função objetiva de uma conexão de bambu é dar continuidade estrutural entre os elementos que conecta. Isso significa que as forças têm de ser transmitidas de maneira preestabelecida, e as deformações devem ser mantidas sob controle.

Há uma série de condicionantes que são internos ou externos ao material que interferem no design dessa conexão.

Os condicionantes internos são aqueles relativos ao material em si e suas características, como as propriedades mecânicas, e sua geometria, e tem em consideração principalmente suas limitações como a ortotropia, a baixa resistência a esforços tangenciais e a variabilidade dimensional (ARCE, 1993).

Os condicionantes internos determinaram princípios de design que devem estar presentes na hora de conceber as uniões, como evitar pregos ou extremidades de colmos abertas, a resolução dos problemas de adaptabilidade do tamanho e transferência das forças axiais do colmo.

Os condicionantes externos, para Arce (1993), são uma lista de princípios que o projeto de design da conexão deve ter:

1) Deve-se maximizar os bons atributos do colmo, levando vantagem das boas propriedades e evitando as más;

2) Simplicidade. A princípio, o bambu deve resolver o déficit de infraestruturas de locais com condições de desenvolvimento mais desfavoráveis, portanto com equipamentos e recursos mais limitados. Deve-se levar em consideração os recursos envolvidos na produção e fabricação das estruturas;

3) Estabilidade e durabilidade das conexões para um uso prolongado da estrutura;

4) Adaptar as dimensões do design a um sistema modular. Essas conexões devem estarem dentro de contextos arquitetônicos modernos em que a variedade de materiais é enorme e utilizá-los devido à necessidade.

5) Previsibilidade dos esforços. Controlar como a transmissão das cargas será feita durante a conexão, prevendo tensões residuais. 
6) Custo-benefício da solução adotada.

Uma proposta de conexão, então, será restringida pelos condicionantes internos do material e, ao mesmo tempo, será valorizada qualitativamente com base nos condicionantes externos que determinam quais caraterísticas são as desejáveis.

4.2.2.2

Classificação de conexões

Vários autores estabeleceram alguns critérios próprios para classificar os diferentes tipos de conexões, alguns pela geometria, pela transmissão de esforços, pelo custo, etc.

Janssen (2000) faz sua classificação das conexões com base em três critérios:

1) Segundo quem faz a transmissão de esforços. Pode ser feita pelo colmo ou por meio de algum elemento complementar;

2) Segundo a parte do colmo que faz a transmissão dos esforços. Existem três opções: a superfície interior do colmo (oco do internó), a superfície exterior do colmo (córtex) ou a superfície da seção transversal do colmo (paredes);

3) Segundo a direção do elemento complementar. Há duas op- paralelo ao eixo axial do colmo (direção das fibras)

A partir daí, estabelece oito grandes tipologias que agrupam os diferentes designs de conexões, sendo dois dos grupos só proposições teóricas, e uma delas não é para colmos de bambu senão para ripas dele obtidas.

\section{Grupo 1. Conexões feitas pela} transmissão de esforços pela secção transversal completa

Este grupo engloba a maioria das conexões tradicionais feitas na arquitetura vernacular (Figura 14). As amarrações são frequentemente utilizadas para dar rigidez ao conjunto, e não são consideradas elementos complementares de transmissão de esforços principais, assim como outros elementos que ajudam na absorção de tensões de cisalhamento.

Essas conexões estão projetadas principalmente para trabalhar à compressão, e não são boas conexões para elementos solicitados à tração, pois o princípio básico é o do apoio e da pressão da seção de um colmo sobre o outro.

Necessitam de muita precisão no corte para transferir as cargas de um colmo a outro por meio do máximo de superfície possível.

Grupo 2. Conexões feitas pela transmissão de esforços pelo internó por meio de um elemento complementar paralelo

Estas conexões precisam geralmente preencher a cavidade do internó com algum material, especialmente concreto ou graute, pois a sua fluidez antes da cura facilita o preenchimento do oco inteiro (Figura 15). Outra opção é usar um tarugo de madeira para tal função. O elemento complementar que pode ser uma barra metálica rosqueada ou um vergalhão está inserido na madeira ou no graute e se projeta além do colmo. Pode-se usar braçadeiras, amarraçñoes ou anéis de compressão que exercerão uma pressão distribuída na parede externa do colmo para melhorar o atrito e aderência do graute ou madeira com parede interior do colmo. Também é possível utilizar adesivos aderentes para melhorar a fixação dos tarugos de madeira de formas regulares, com o interior do colmo que não são sempre perfeitamente de seção circular.

Grupo 3. Conexões feitas pela transmissão de esforços pelo internó por meio de um elemento complementar perpendicular

As conexões deste grupo são uma proposta teórica. $\mathrm{Na}$ prática, são 
difíceis de executar para que tenham um bom desempenho.

\section{Grupo 4. Conexões feitas pela} transmissão de esforços pela seção transversal do colmo por meio de um elemento complementar paralelo

Os elementos complementares das conexões deste grupo costumam ser cavilhas metálicas ou de madeira paralelas que se projetam além da extremidade do colmo (Figura 16). Em alguns exemplos, o próprio pino é sustentado por uma cavilha ou por um parafuso perpendicular que recebe a transmissão de cargas e pode ser interpretado consequentemente como uma conexão pertencente ao grupo 5. Amarras e braçadeiras costumam ser necessárias em alguns casos para agregar rigidez à solução.

Grupo 5. Conexões feitas pela transmissão de esforços pela seção transversal do colmo por meio de um elemento complementar perpendicular

Esse grupo também utiliza elementos complementares de transmissão, como cavilhas de madeira ou até de bambu, em casos mais rústicos, e parafusos e barras metálicas (Figura 17). Nesse caso, utilizam-se também amarras ou braça- deiras que ajudam a manter a pressão de contato entre os colmos da conexão. Outros elementos utilizados são recortes de pranchas de madeira que se fixam nas laterais dos colmos, permitindo conexões múltiplas com várias direções, com uma rigidez muito elevada.

\section{Grupo 6. Conexões feitas pela} transmissão de esforços pelo exterior do colmo por meio de um elemento paralelo

As conexões desse grupo, quando o material de transmissão é a amarração de fibras vegetais ou sintéticas, fazem parte das uniões da tradição construtiva vernacular, os grandes exemplos destas conexões podem ser vistos em qualquer andaime na Ásia (Figura 18). Aproveita-se a compressão da amarra ção na superfície externa do bambu para fixar os outros elementos, que podem ser outros colmos de bambu ou barras. As opções mais evoluídas deste grupo utilizam braçadeiras metálicas.

Grupo 7.Conexões feitas pela transmissão de esforços pelo exterior do colmo por meio de um elemento complementar perpendicular

As conexões deste grupo são uma proposta teórica. $\mathrm{Na}$ prática, são difíceis de executar para que tenham um bom desempenho.

É necessário estabelecer para as conexões qual grau de complexidade técnica para serem manufaturadas. Isso tem a ver com a capacitação dos recursos humanos disponíveis, mas também está relacionado ao nível de complexidade tecnológica embutida no processo de produção, que está determinada pelos recursos materiais, energéticos e de desenvolvimento técnico das ferramentas de produção, e dos elementos complementares. Não há o mesmo grau de sofisticação entre uma amarração com sisal entre dois colmos (Figura 19) e uma conexão multiespacial como a criada pelo Shoei Yoh (Figura 20).

Conhecer as limitações técnicas do entorno onde será construído com bambu é essencial, não para escolher a conexão com melhor desempenho, mas para projetar a melhor conexão para aquele contexto, com todas as limitações que o ambiente traz consigo.

São estabelecidos três níveis diferentes de complexidade tecnológica nas conexões:

- Nível 1: conexões com uso de ferramentas básicas e de materias complementares básicos não industrializados. Amarrações com sisal, cortes com encaixes sim- 


\section{FIGURA 14}

Conexões do grupo 1.

Fonte: JANSSEN, 2000.

\section{FIGURA 15}

Conexões do grupo 2 . Fonte: JANSSEN, 2000.

\section{FIGURA 16}

Conexões do grupo 3.

Fonte: JANSSEN, 2000.

\section{FIGURA 17}

Conexões do grupo 4.

Fonte: JANSSEN, 2000.

\section{FIGURA 18}

Conexões do grupo 5.

Fonte: JANSSEN, 2000.
14
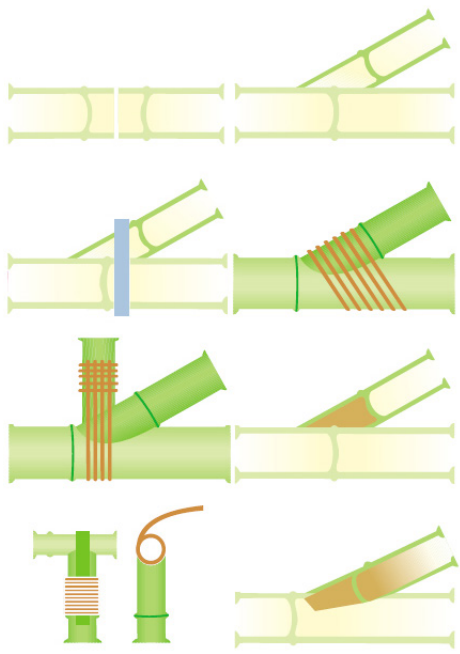

16
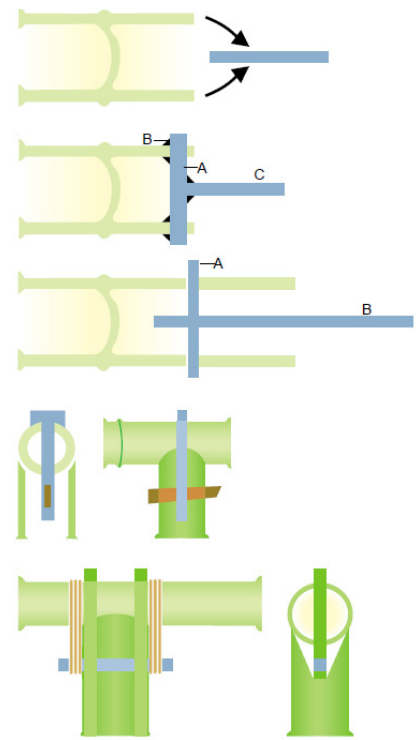

15
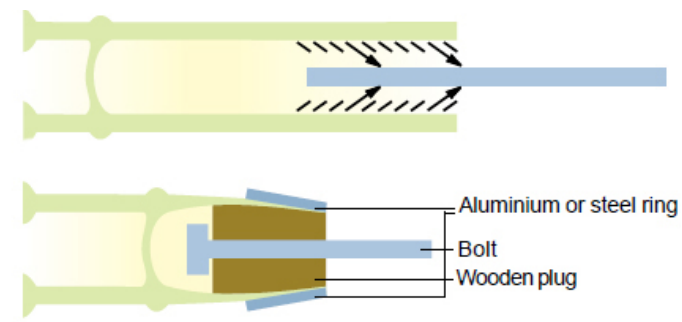

-Cement grout

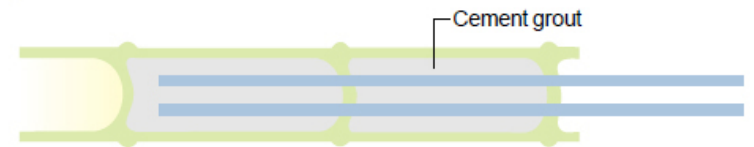

17
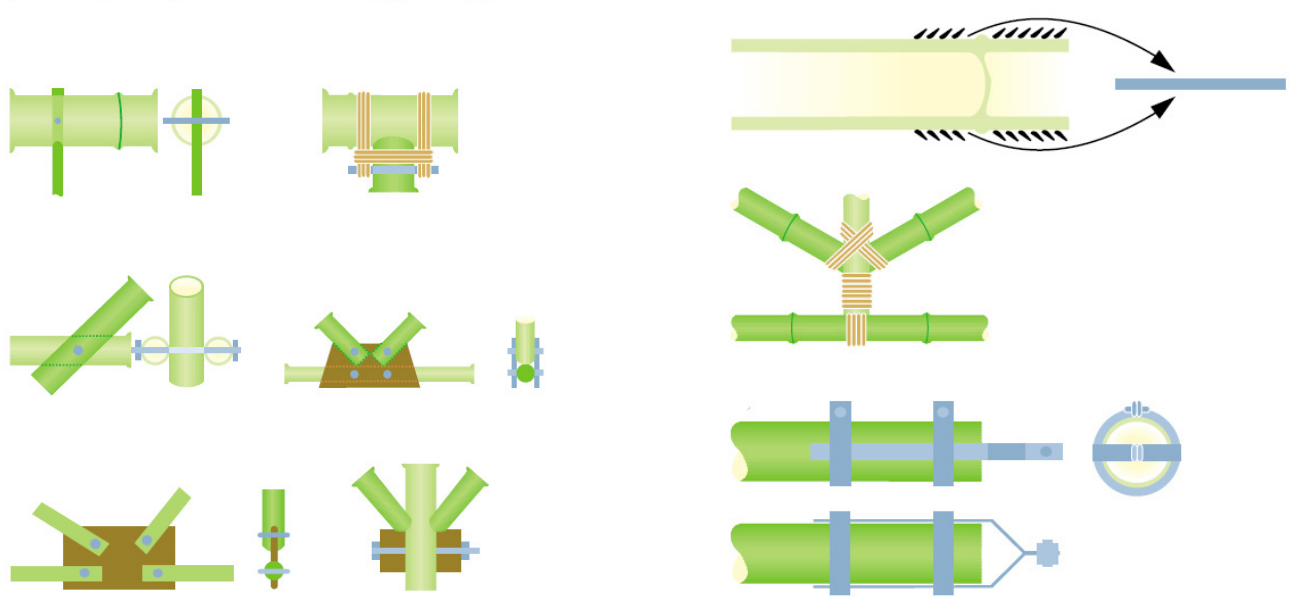

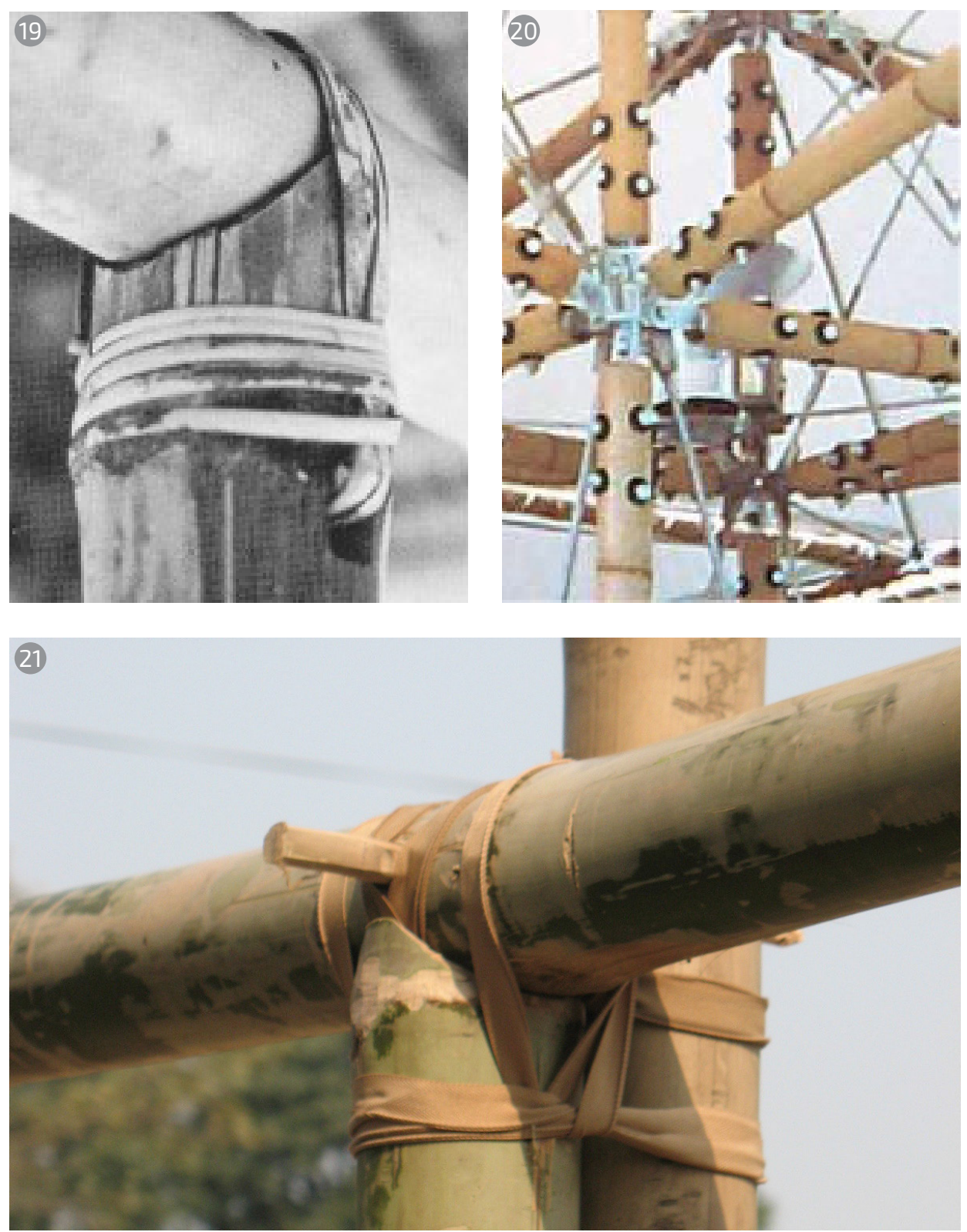

FIGURA 19

Conexão rústica com amarrações de fibras vegetais. Disponível em: <http://bambus. rwth-aachen. de/de/Referate/ bambusverbind/ seilbund.htm>.

Acesso em mar. 2017.

FIGURA 20

Conexão criada por Shoei Yoh em 1989 para coberturas em Fukuoka. Disponível em: <http://bambus. rwth-aachen.de/eng/ reports/connect/ bolt/bolt.htmls. Acesso em mar. 2017.

FIGURA 21

Conexão de apoio no topo simples, com cailha e amarra ções de fibras. Nível 1 de complexidade tecnológica. Disponível em: <http://bambus. rwth-aachen.de/ eng/reports/connect/friction/friction.html>. Acesso em mar. 2017. 
FIGURA 22

Conexão multiespacial com parafusos $\mathrm{e}$ preenchimento dos internós com graute. Nível 2 de complexidade tecnológica. Disponível em: . Acesso em mar. 2017.Nível 3: conexões que utilizam ferramentas e/ ou elementos suplementares produzidos por outros agentes, como serralheiros, indústria siderúrgica ou marceneiros. Também possui um grau muito elevado de consumo de recursos embutidos na produção (Figura 23).

\section{FIGURA 23}

Conexão com elemento complementar metálico multidireccional customizado em siderurgia do arquiteto Markus Heinsdorff. Nível 3 de complexidade tecnológica. Foto: Tong Ling Feng.

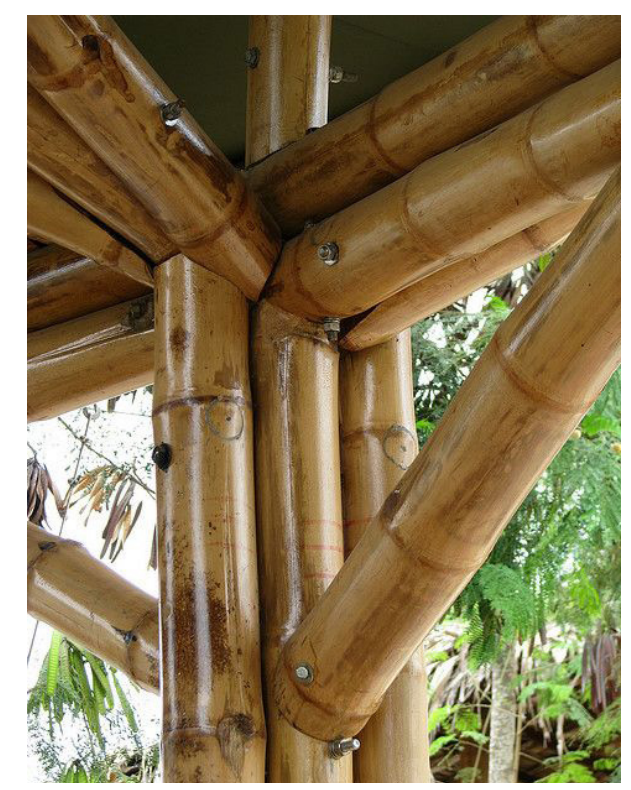

ples, não existindo nenhum processo de construção onde haja consumo elétrico (Figura 21).

- Nível 2: conexões realizadas com uso de ferramentas elétricas e/ou com elementos suplementares industrializados básicos, como o cimento, barras rosqueadas, vergalhões, entre outros. Elementos complementares modulares e seriados, sem produção exclusiva para uma obra (Figura 22).

- Nível 3: conexões que utilizam ferramentas e/ou elementos suplementares produzidos por outros agentes, como serralheiros, indústria siderúrgica ou marceneiros. Também possui um grau muito elevado de consumo de recursos embutidos na produção (Figura 23).

Padovan (2010) faz um estudo mais minucioso da classificação das conexões tradicionais realizada anteriormente por Jayanetti e Follett (1998). Esse estudo é baseado em um primeiro nível pela direção dos colmos, e, no segundo nível de definição de Padovan (2010), por como se estabelece a relação entre os vários colmos da conexão. Grupo 1 - Conexões unidirecionais

- Colmos inteiros sobrepostos (Figura 24 - conexão por sobreposição de colmos, com cavilhas e amarração);

- Colmos com corte de emenda (Figura 25 - conexão com corte de meio colmo e amarração);
- Colmos inteiros com segmentos semicilíndricos de bambu travando-os (Figura 26 - conexão com talas de bambu, amarrações e cavilhas);

- Colmos inteiros com luvas e tarugos (Figura 27 - emendas com tarugos ou luvas).

Grupo 2 - Conexões ortogonais

- Conexões ortogonais a topo (Figura 28 - conexão apoio ortogonal de topo);

- Conexões ortogonais laterais Figura 29 - conexão ortogonal lateral reta);

- Conexões ortogonais laterais duplas em ângulo reto (Figura 30 - conexão lateral ortogonal dupla com amarrções);

- Conexões ortogonais laterais duplas em linha (Figura 31 - conexão ortogonal lateral em linha com amarrações);

- Conexões ortogonais sobrepostas (Figura 32 - conexão de pilar duplo com apoio de topo, amarrações e cavilha).

Grupo 3 - Conexões de elementos diagonais

- Conexões diagonais com elementos horizontais (Figura 33 - conexão diagonal com elemento horizontal);

- Conexões diagonais com elementos verticais e horizontais ( $\mathrm{Fi}$ gura 34 - conexão diagonal com elementos horizontais).

Grupo 4 - Conexões por traspasso 

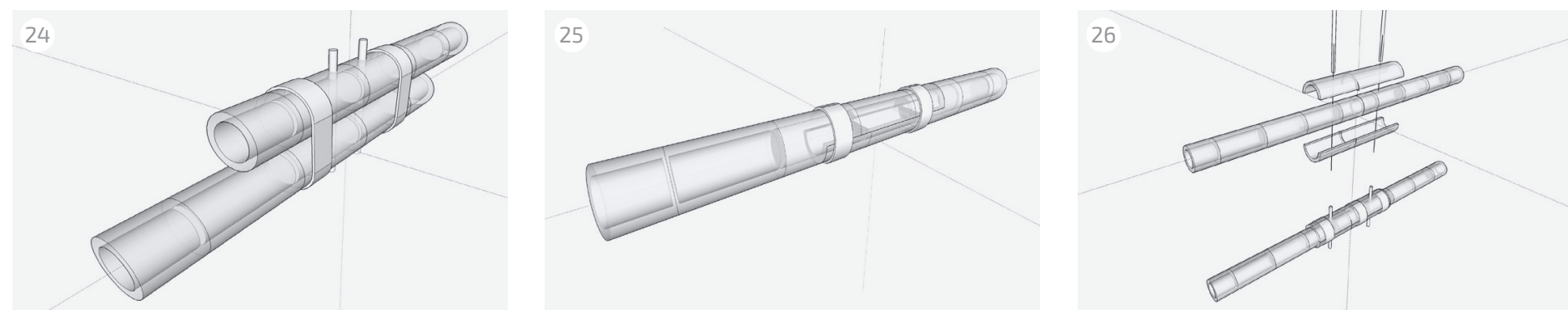

FIGURAS 24 A 35

Autor: Joan Font.
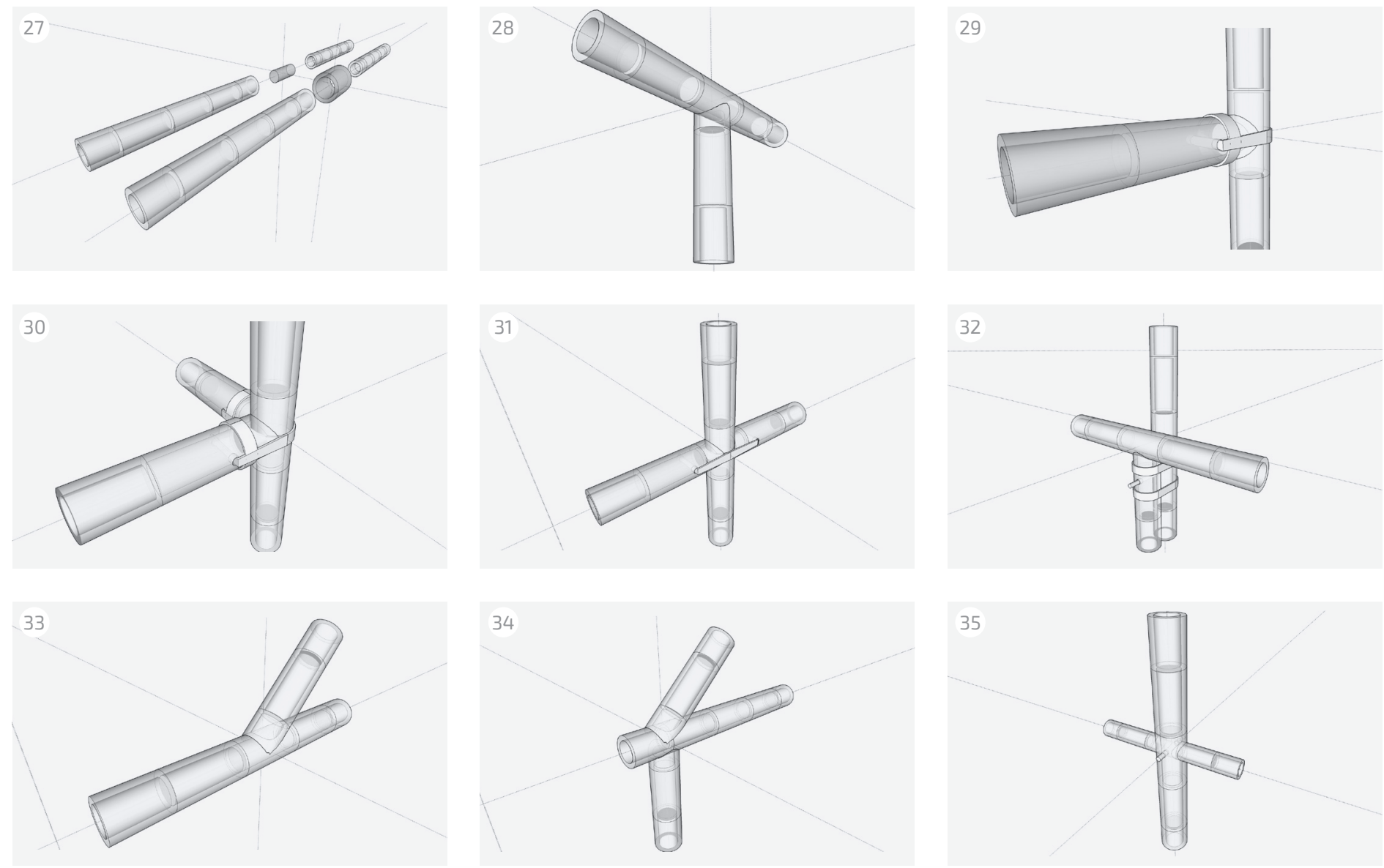
FIGURA 36

Conexão multidirecional do Renzo Piano. Disponível em: $<$ http://bambus.rw-

th-aachen.de/eng/reports/connect/bolt/ bolt.html>. Acesso em mar. 2017.

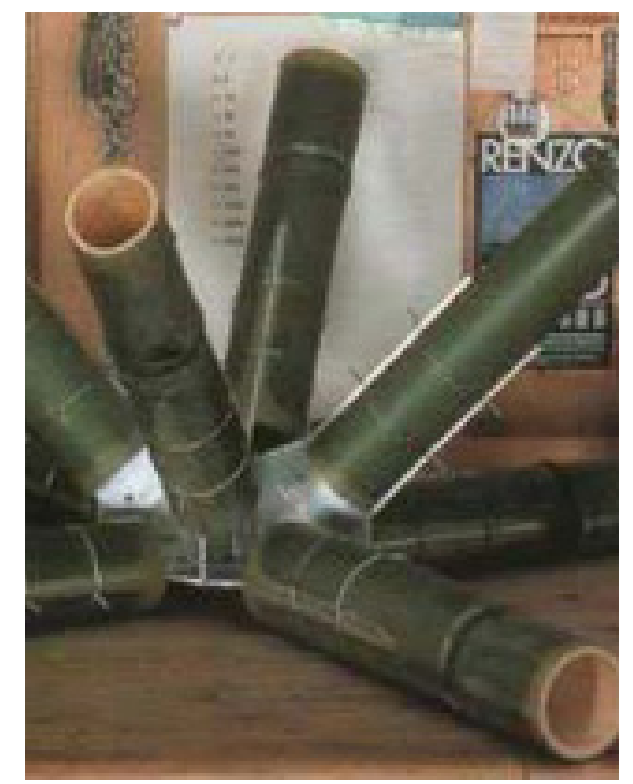

dos elementos (Figura 35 - conexão por traspasse e cavilha).

É possível inserir-se um novo grupo com as conexões multidirecionais, que seriam todas aquelas conexões que estão caraterizadas pela complexidade geométrica e que são possíveis graças aos avanços tecnológicos e à utilização de elementos complementares muito sofisticados (Figura 36).

\section{2 .2 .3}

Princípios construtivos das conexões

Fazer conexões com bambu apresenta complicações devidas à macroestrutura do bambu. O colmo é oco, cônico, com nós distribuídos irregularmente e com irregularidades também na seção circular. Essas disposições têm que estar assumidas no momento de projetar uma solução construtiva para uma estrutura (JANSSEN, 2000).

Outra das deficiências que têm as conexões de bambu é a falta de rigidez do conjunto, seja entre colmos ou entre o colmo e algum elemento complementar. A frouxidão da solução pode transferir forças em direções não previstas, que podem sobrecarregar elementos da estrutura e até os fazerem entrar em colapso.

O principal requerimento para um bom desempenho na construção que se consegue por meio da rigidez.

Um dos principais e mais antigo aliado nas conexões, segundo Minke (2010), é a amarração, ou elementos complementares de fixação e enrijecimento, como cordas de fibras naturais ou sintéticas, couro úmido (que enrijece e encolhe quando seca) ou arame galvanizado. Esses sistemas, assim como as braçadeiras metálicas, funcionam comprimindo radialmente os colmos e melhorando sua resistência à tração perpendicular às fibras e ao fendilhamento.

Em estruturas temporárias, é melhor usar amarrações de sisal e outras cordas, para facilitar o reaproveitamento, a desmontagem e evitar o desperdiço de material.

Braçadeiras metálicas são o complemento ideal para quando existem elementos extras que transmitem esforços à seção do colmo, como parafusos, cavilhas e conectores metálicos ou para uma distribuição adequada das pressões exercidas entre colmos (Figura 37).

As braçadeiras atuam em contato com a superfície externa, mas outra prática muito utilizada e recomendável nas conexões é a do preenchimento de graute nos internós, para ajudar, por contato da superfície interna, à transferência de esforços originadas pelas cavilhas, parafusos e conectores metálicos.

Como descrevem Frey e Von 
Schaewen (2013), Marcelo Villegas e Simón Vélez utilizaram o encaixe com boca de peixe, perfurando os internós dos colmos e preenchendo com concreto e uma barra rosqueada ou vergalhão como fixação. Isso dei$\mathrm{xa}$ as conexões mais rígidas e, portanto, proporciona ao sistema todo um maior grau de estaticidade.

Nas conexões, é recomendável, sempre que possível, fazer a transferência de esforços a outro colmo ou a um elemento complementar, pela máxima superfície de contato do bam$\mathrm{bu}$, e que as forças transferidas nos extremos sejam homogêneas e não haja concentração, nem excentricidade na carga axial que possa originar flambagens. Outros esforços que são interessantes evitar são os momentos fletores, em que haja algum tipo de dano na parede do colmo (MINKE, 2000).

Os nós, além de serem uma descontinuidade que pode reduzir a capacidade resistente em alguns esforços em certas direções, também ajudam a estruturar e, de certa forma, aumentam a capacidade resistente, por exemplo, na tração e compressão perpendiculares às fibras.

É recomendável, então, aproveitar essa condição para usar os nós como elemento de reforço em conexões e em situações em que as estruturas tenham esforços combinados. Sempre que pos- sível, deve-se colocar os nós nas conexões ou perto delas, para aumentar a estabilidade e a resistência da solução.

As conexões mais eficientes são aquelas em que um elemento complementar feito com um material isotrópico resistente (aço) faz a transferência de esforços, absorvendo os momentos fletores e outras tensões residuais, e assim permite que os bambus trabalhem exclusivamente a tração-compressão. Estas conexões que utilizam terminações metálicas evitando o contato direto entre bambus, evita a necessidade de cortes especiais, que são muito difíceis de executar com precisão.

Para a criação de estruturas de treliças espaciais, pode-se utilizar o sistema MERO, formado por esferas metálicas com furos rosqueados unidos a conectores metálicos fixados nas pontas dos colmos (Figura 38).

A padronização de uma conexão com comportamentos controlados a partir de elementos pré-fabricados facilita a produção seriada e tem um controle de qualidade realizado durante a fabricação muito mais elevado do que qualquer elemento produzido pela mão-de-obra executora no canteiro.

Os princípios construtivos das conexões buscam essencialmente melhorar a estabilidade das uniões. Para isso, é importante fornecer rigidez na união

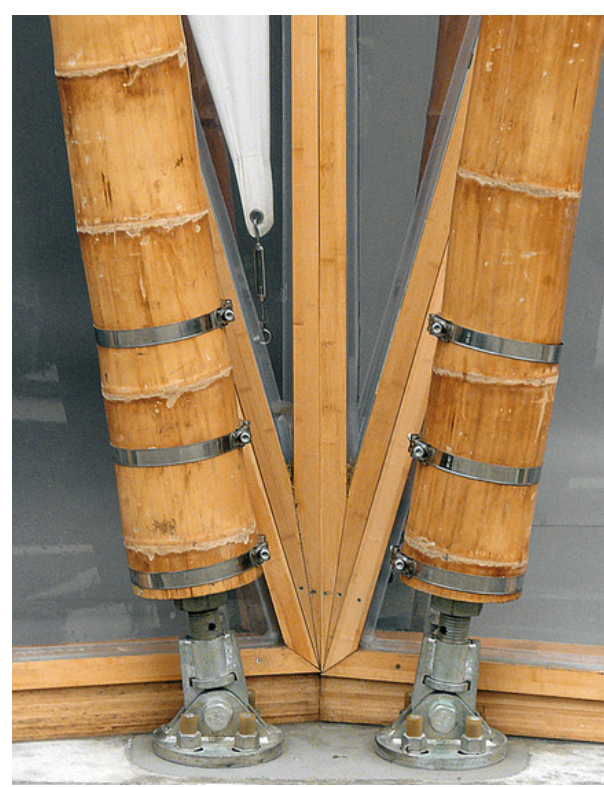

FIGURA 37

Braçadeiras metálicas para conexão de fundação. Foto: Frank Kaltenbach. Disponível em: $<$ http://www. detail-online. com/inspiration/ bamboo-pavilionfor-the-exposhanghai-103526. $\mathrm{html}>$. Acesso em mar. 2017.

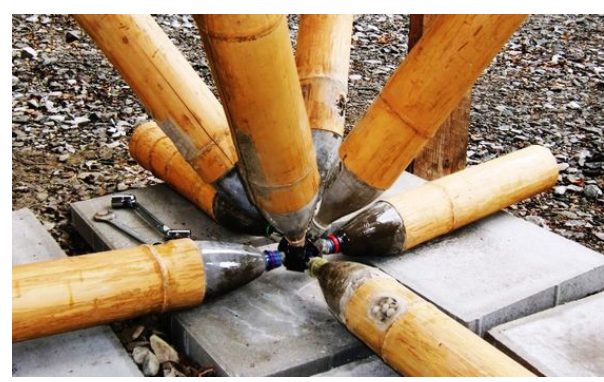

FIGURA 38

Conexão

multidirecional do tipo MERO. Disponível em: <http://www. saevfors.se/Space Frames.html>. Acesso em mar. 2017 
entre o colmo e os elementos complementares. Já a rigidez entre elementos complementares ou entre colmos dependerá do sistema estrutural em si e do seu grau de hiperestaticidade.

Existem muitas publicações sobre descrições de soluções construtivas e de design de conexões. Mas há poucas explicações sobre as deformações que podem sofrer, os esforços que podem transmitir e as patologias que podem ocasionar (JANSSEN, 2000).

\subsubsection{Cálculo de estruturas}

O intuito do design de conexões estruturais é conseguir continuidade estrutural entre dois ou mais elementos para que se transfira a carga de um para outro (JANSSEN, 2000).

Os requerimentos essenciais são:

- Transmissão dos esforços prees-

tabelecidos no projeto;

- Desvios de esforços que possam ser previstos e que precisam ser mantidos dentro de limites aceitáveis.

Janssen (2000) descreve três metodologias para cálculo de conexões:

1) Cálculos baseados em relatórios de ensaio de conexões em escala natural. Nesse caso, a solução da conexão e o tamanho dos colmos já vêm especificados, assim como o tamanho dos elementos complementares que ajudam na transição de esforços. A limitação está em não poder extrapolar a solução para outros mecanismos semelhantes ou outros tipos de bambu. A garantia de um correto funcionamento só é válida se seguirem as especificações do relatório com exatidão.

2) Cálculos baseados em relatórios de ensaios parciais, a partir de dados das tensões admissíveis para elementos da conexão. Contudo, precisa-se de um bom banco de dados que contenha informações amplas, confiáveis e verificáveis.

3) Cálculos baseados em dados sobre mecânica básica das uniões e seus materiais, o chamado "princípios de design alternativo”. Esses princípios dão referências e fatores que precisam ser situados corretamente para validar a capacitação dos elementos da conexão. Baseado em detalhes obtidos em cálculos não numéricos, determinam, por exemplo, os intervalos de espaçamentos entre elementos que formam o detalhe.

A diferença entre os colmos de bambu e os materiais convencionais para estrutura está basicamente no fato de que o bambu passa do meio natural de onde é extraído para a obra, quase sem processamento. Isso supõe ter que lidar com todos os defeitos que as irregularidades da sua forma trazem consigo. Por ou- tro lado, materiais como concreto, madeira e aço passam por processos complexos muito mais custosos, mas que permitem uma variabilidade de formas muito mais ampla, que se traduz em estruturas formalmente muito complexas (JANSSEN, 2000).

A condição cônica do colmo dificulta a abstração e a simplificação dos cálculos, por exemplo, na hora de estabelecer o momento de inércia do elemento é preciso calcular os valores pelos diâmetros dos dois extremos (JANSSEN, 2000).

As tensões admissíveis do bambu, que no fim são os parâmetros finais para o cálculo, dependem do tipo de esforço, da direção e do sentido em que se aplica no colmo solicitado, a duração da carga, o teor de umidade do material, os valores obtidos em ensaios para o tipo de tensão e da normativa do país em que se constrói, pois cada país utiliza padrões diferentes de avaliação (MINKE, 2010).

\subsection{Princípios construtivos de estruturas de bambu}

Em áreas mais rurais sem um controle normativo demasiado rígido, a construção é feita com base na experiência. Esses princípios construtivos transmitidos por gerações por meio do conhecimento obtido a 
partir da metodologia tentativa-erro são, às vezes, mais inacessíveis que as soluções propostas por métodos científicos.

O problema principal dos relatórios baseados em experiência direta no canteiro e na construção tradicional é a limitação nas modificações das soluções construtivas, já que a réplica tem que se dar em condições semelhantes, caso contrário, será considerada outra especulação construtiva, e não uma solução consolidada (JANSSEN, 2000).

Dunkelber (1996), Janssen (2000), Hidalgo-López (2004), Minke (2010), entre outros autores, assim como em normas técnicas de vários países, listam uma série de boas práticas construtivas que, ao serem cumpridas, farão com que a estrutura tenha um desempenho correto:

- Proteção dos colmos da chuva, utilização de beirais para proteger colunas de bambu de um terço da altura da edificação desde a base do colmo-pilar;

- Colocar barreiras nas extremidades dos colmos para dificultar a penetração de agua ou insetos;

- Não utilizar pregos, nem para fixar outros colmos nem para fixar outros componentes construtivos. Perfurações que tracionam transversalmente as paredes do colmo são totalmente danosas. No caso de precisar utilizar pregos, barras ou parafusos para uniões entre colmos, deve ser feito previamente o furo com furadeira;

- Não utilizar acabamentos impermeáveis que não permitam a transpiração do colmo. Se acumular umidade, pode produzir condensações que atraem fungos e variações dimensionais que façam rachar o bambu pelas uniões;

- É recomendável que no fim do colmo haja um nó, se não for possível, recomenda-se que a distância até o nó mais próximo não seja superior a $12 \mathrm{~cm}$ Se não for possível, é recomendável colocar uma braçadeira;

- A tradição recomenda que a flecha máxima de um colmo solicitado a flexão estática seja inferior a L/150;

- É necessário utilizar bambus secos, e o design arquitetônico tem de zelar para que assim se mantenha ao longo da vida útil do edifício (JANSSEN, 2000);

- As perfurações para colocação de parafusos devem estar alinhadas e ter um diâmetro superior ao do parafuso em si, para evitar o fendilhamento. Minke (2010) recomenda diâmetros superiores a $1,5 \mathrm{~mm}$;

- Elementos metálicos utilizados

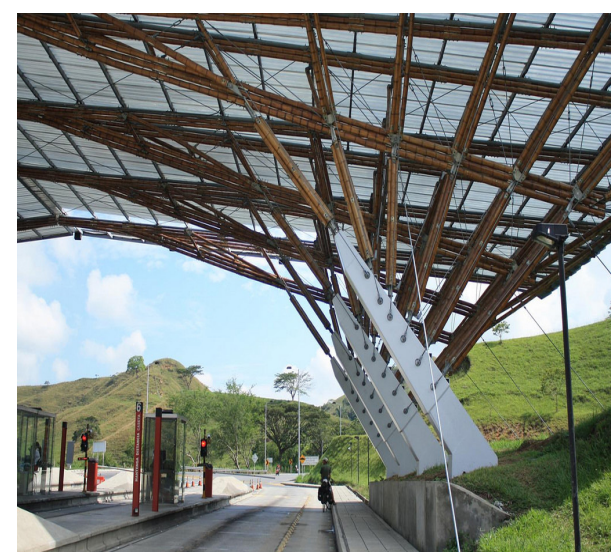

FIGURA 39

Sapata do pedágio da estrada ArmeniaPereira na Colômbia, arquiteto Simón Hosie. Disponível em: $<$ https://www. flickr.com/photos/ eager/14406125781 > Acesso em mar. 2017. 
em uniões devem ter tratamentos antioxidantes;

- Para cargas concentradas em entrenós é recomendável preencher o entrenó solicitado de graute. Quando for em cima do nó, pode se melhorar o desempenho também preenchendo de graute os entrenós contíguos.

Existem alguns critérios também para as funções específicas dentro da estrutura.

As fundações sempre têm que estar elevadas em relação ao nível do solo, e, além disso, é bom utilizar vergalhões ancorados na sapata, ou algum tipo de conector metálico que afaste o colmo do bambu das sapatas mesmo, também para protegê-lo da umidade (Figura 39).

$\mathrm{Na}$ construção de estruturas temporárias, não se pode apoiar colmos verticais no solo sem fixação, pois qualquer movimentação mínima pode provocar rachaduras neste pilar. A fixação dos pilares no solo propicia mais hiperestaticidade ao conjunto estrutural para evitar movimentações do sistema todo.

Quando são utilizados colmos para fazer vigas e tesouras, as formas estruturais devem ser tais que o comprimento dos elementos de compressão seja mantido adequado para evitar tão rígidas quanto possível pelo mesmo motivo (ARCE, 1993).

Utilizar um colmo só como viga pode não ser muito adequado devido à flecha muito grande que pode gerar. Apesar de ter um módulo de ruptura da flexão estática muito alto o módulo de elasticidade nesta solicitação mecânica também é muito alto o que pode criar deformações muito grandes que podem complicar outros sistemas prediais que não têm essa flexibilidade. Por isso, é recomendável utilizar colmos curtos, simples e com pouca carga.

Uma opção bastante utilizada é a de aumentar a altura estrutural do bambu e converter a estrutura em um sistema híbrido, com elementos que trabalham por seção-ativa, colocando vários colmos um sobre o outro e conectá-los com passadores inclinados.

Apoiar as vigas pelo nó, caso não seja possível preencher o extremo com graute para dar rigidez e estabilidade, é uma das soluções mais comuns para evitar o esmagamento do bambu.

\subsection{Desempenho de estruturas de bambu}

Toda construção arquitetônica tem uma série de requisitos dos usuários relativa à segurança, habitabilidade e sustentabilidade que devem ser cumpridas para que tenha um bom desempenho (ABNT NBR 15.575, 2013). Essas exigências, no caso de focar no estudo de estruturas, são:

- Estabilidade estrutural, requisito para garantir a segurança dos usuários e a integridade do edifício;

- Salubridade, para que os elementos que compõem a estrutura não tenham defeitos nocivos contra a saúde dos usuários;

- Durabilidade, para que a estrutura garanta a estabilidade durante o máximo de tempo possível, ou segundo a vida útil prevista pelo projetista;

- Manutenabilidade, para possibilitar conservação e correção de defeitos que comprometam a durabilidade e, em última instância, a estabilidade;

- Impacto ambiental, para utilização de recursos tanto materiais como humanos que tenham uma pegada ambiental mínima no entorno.

A estabilidade estrutural e a durabilidade são os aspectos mais importantes na hora de projetar estruturas de bambu, criar soluções que permitam a integridade de uma estrutura com um impacto ambiental baixo durante o maior espaço de tempo possível.

Quando se dimensionam estruturas de bambu, os valores utilizados são dos estados limites últimos dos materiais, que estão associados à falha do sistema e ao colapso estrutural 
do conjunto ou dos elementos que o conformam, também inclui a perda de equilíbrio da estrutura ou parte dela ou à deformação excessiva. Os estados limites de serviço são aqueles que, quando atingidos pelos estados, dos elementos ou conjunto estrutural, deixam de cumprir os seus critérios de serviço. Critérios como deformações excessivas que afetam visual ou fisicamente o uso da estrutura, ou causam danos a elementos não estruturais que induzam ao mau funcionamento da construção (SOARES, 2013).

Nesse caso, a manutenabilidade de uma estrutura de bambu é um fator importante a se considerar durante a fase de projeto, porque a vida útil do bambu dependendo das condições ambientais é em geral muito mais baixa que os materiais estruturais convencionais, entre 10 e 20 anos. Por isso, é importante como princípio construtivo que as estruturas possibilitem e facilitem a substituição de todos os elementos de bambu que a compõem, sem comprometer a integridade da estrutura para influir na durabilidade do sistema em conjunto.

A estrutura, assim como qualquer outro sistema integrante de um edifício, é influenciada pela ação de quatro agentes diferentes que são os responsáveis por cada um dos estágios da construção:
1) Fornecedor: o agente que supre o material, é responsável pela produção e a qualidade dos bambus; 2) Arquiteto ou engenheiro: o agente responsável pela concepção do espaço construído, do projeto tanto arquitetônico como de cálculo e de todas as soluções construtivas adotadas principalmente nas conexões que são os pontos mais sensíveis; 3 ) Construtor e incorporador: o agente responsável pela execução da obra e pelo cumprimento das especificações em projeto; 4) Usuário: o agente responsável por usufruir e gerenciar o edifício uma vez terminado, portanto, é responsável pela manutenção do edifício.

\subsection{1 \\ Patologias}

Qualquer patologia que ocorra no bambu pode ter sua origem numa ação incorreta de qualquer um dos quatro agentes da construção (fornecedor, projetista, executor, usuário).

Em geral, as manifestações patológicas do bambu que comprometem a estabilidade do material, se apresentam como fendas e rachaduras na direção axial do colmo, que é o sentido paralelo às fibras (ABD. LATIF et al., 1993). Inclusive aquelas tensões mesmo que não representem a priori uma tração perpendicular às fibras pode resultar em fendilhamento.

Por isso, é preciso fazer uma análise muito cuidadosa para averiguar a origem exata de uma manifestação patológica mecânica no colmo.

Quando o bambu colapsa, ocasiona uma separação entre as fibras, mas elas continuam unidas e, ao remover a carga, volta à sua posição inicial. Esse fenômeno é importante e explica o comportamento tão tenaz das estruturas de bambu submetidas a esforços horizontais decorrentes de terremotos, pois elas continuam em pé sem colapso geral da estrutura. Exatamente como ocorreu no terremoto de 1999, em Armenia, e em toda a região do eixo cafeeiro da Colômbia.

$\mathrm{Na}$ análise do desempenho de estruturas de bambu, encontam-se patologias que afetam a durabilidade do bambu e, em última instância, a estabilidade: outras patologias afetam diretamente a estabilidade degradando os colmos e outras patologias menos usuais que afetam a salubridade do ambiente ou o conforto visual.

4.4.1.1

Durabilidade

O bambu como material de estruturas tem uma vida muito curta em comparação aos outros materiais conven- 
cionais. É importante então prever no projeto as proteções adequadas para conservar suas propriedades intactas o máximo de tempo possível e, no caso de falhas, facilitar a manutenção.

A NBR 5462 (1994) descreve três tipos de manutenção que tanto os engenheiros como os arquitetos devem ter presente no momento de projetar, para prevenir qualquer falha na construção:

- Manutenção corretiva: efetuada após a ocorrência de uma pane destinada a recolocar um item em condições de executar uma função requerida;

- Manutenção preventiva: efetuada em intervalos predeterminados, ou de acordo com critérios prescritos, destinada a reduzir a probabilidade de falha ou a degradação do funcionamento de um item;

- Manutenção preditiva: permite garantir uma qualidade de serviço desejada, com base na aplicação sistemática de técnicas de análise, utilizando-se de meios de supervisão centralizados ou de amostragem, para reduzir ao mínimo a manutenção preventiva e diminuir a manutenção corretiva.

A manutenção preditiva das estruturas de bambu é uma parte fundamental no momento de projetar estruturas baseadas nesse material, e devido à durabilidade tão baixa do bambu, 10 a 15 anos em ambientes controlados, é necessário ter essa limitação presente.

A manutenção preventiva e corretiva são atribuições do usuário do edifício, mas o projeto deve facilitar as operações.

Quando não se garante a durabilidade do bambu nas estruturas, automaticamente afetará a estabilidade do sistema e, consequentemente, porá em risco a segurança dos usuários.

Os tratamentos preservativos são o principal mecanismo para garantir uma vida útil longa; isso depende do fornecedor, porém, é necessário que na fase de projeto leve-se em consideração a possibilidade de troca de cada um dos colmos integrantes da estrutura. Mas existem algumas ações de projeto e em obra que também contribuirão para aumentar a durabilidade dos bambus:

- A instalação de proteções metálicas nas extremidades dos colmos para dificultar o ataque da região mais vulnerável do bambu, a área do corte, e forçar o difícil ataque pelo córtex.

- Preparação dos terrenos adjacentes para dificultar a aparição de cupins.

- Aplicação de vernizes de proteção em intervalos de tempo determinados.
- Dedetização das estruturas em intervalos de tempo determinados.

4.4.1.2

Estabilidade

A estabilidade do sistema estrutural de bambu depende da qualidade dos colmos e dos elementos conectores, das soluções de projeto escolhidas pelo arquiteto e engenheiro, a correta execução do construtor, e pelo uso correto do usuário.

Quando os colmos estão submetidos a esforços que comprometem sua estabilidade e que não são capazes de resistir, a microestrutura falha e produz uma fratura que se espalha ao longo do colmo.

4.4.1.2.1

Fendilhamento

Ao contrário do que ocorre na madeira, o bambu não tem fibras dispostas radialmente exceto nos nós. Portanto tem menos resistência a esforços cortantes axiais, e a esforços de tração perpendicular às fibras. Isso impede o uso de pregos na construção e nas conexões. A resistência ao fendilhamento é diretamente proporcional à quantidade de feixes vasculares nos tecidos do bambu, portanto, apesar de ser difícil comprovar, a parte interna da parede 
do colmo fendilha mais facilmente que o córtex.

Embora o fendilhamento não seja exatamente uma tração perpendicular pura, simplifica-se para melhor entendimento. Quando um corpo externo (prego) penetra na parede do colmo, este provoca certa tensão tracionando-o. Esta tensão cria uma fratura principalmente no parênquima (a parte não resistente do bambu), que tem uma baixa resistência ao rasgo, e esse rasgo ou fenda vai aumentando na direção paralela às fibras na medida que o corpo vai se deslocando pelo colmo. Caso a tensão seja perpendicular às fibras, a fenda vai aumentando.

Nos ensaios de flexão realizados por Rusinque Guatibonza (2009), o autor observou que a fissura inicial no bambu se propaga em pequena quantidade até encontrar uma zona de intensidade na qual a fissura muda de direção para propagar-se na direção paralela às fibras e, finalmente, causando a falha por cisalhamento.

O comportamento do bambu em quase todos os tipos de tensões limites é o mesmo e acaba manifestando-se como uma rachadura no sentido axial do colmo.

Na Figura 40, observa-se o tipo de cisalhamento que pode levar ao fendilhamento, sendo o principal que ocorre nas estruturas de bambu é o tipo 1 pela tração perpendicular às fibras.

Nos estudos de Vaessen e Janssen (1997) sobre a flexão de colmos inteiros, os autores concluíram que o colmo submetido à flexão fratura pela linha neutra.

Uma fenda pode não oferecer muita informação sobre a origem patológica, mas é importante entender o comportamento, as deformações e tensões criadas pelas conexões para compreender se o elemento está transmitindo uma tensão não prevista ou se é uma falha do material mesmo.

O fendilhamento é a principal causa de desestabilização de uma estrutura de bambu, e a tradição construtiva sempre foi ciente dessa fraqueza, por isso, muitas das soluções construtivas incitam ao uso de braçadeiras e amarrações, para comprimir radialmente o colmo e evitar assim trações tangenciais que o façam fendilhar.

É importante não se usar pregos para as conexões de bambu. Quando se faz uso de conexões metálicas ou que modifiquem a anatomia do bambu, é importante usar reforços para evitar esta tração perpendicular às fibras (Figura 41).

Pequenas descontinuidades e defeitos, principalmente na face externa do colmo, combinadas com esforços não previstos podem facilmente rachar o colmo e diminuir as proprie-

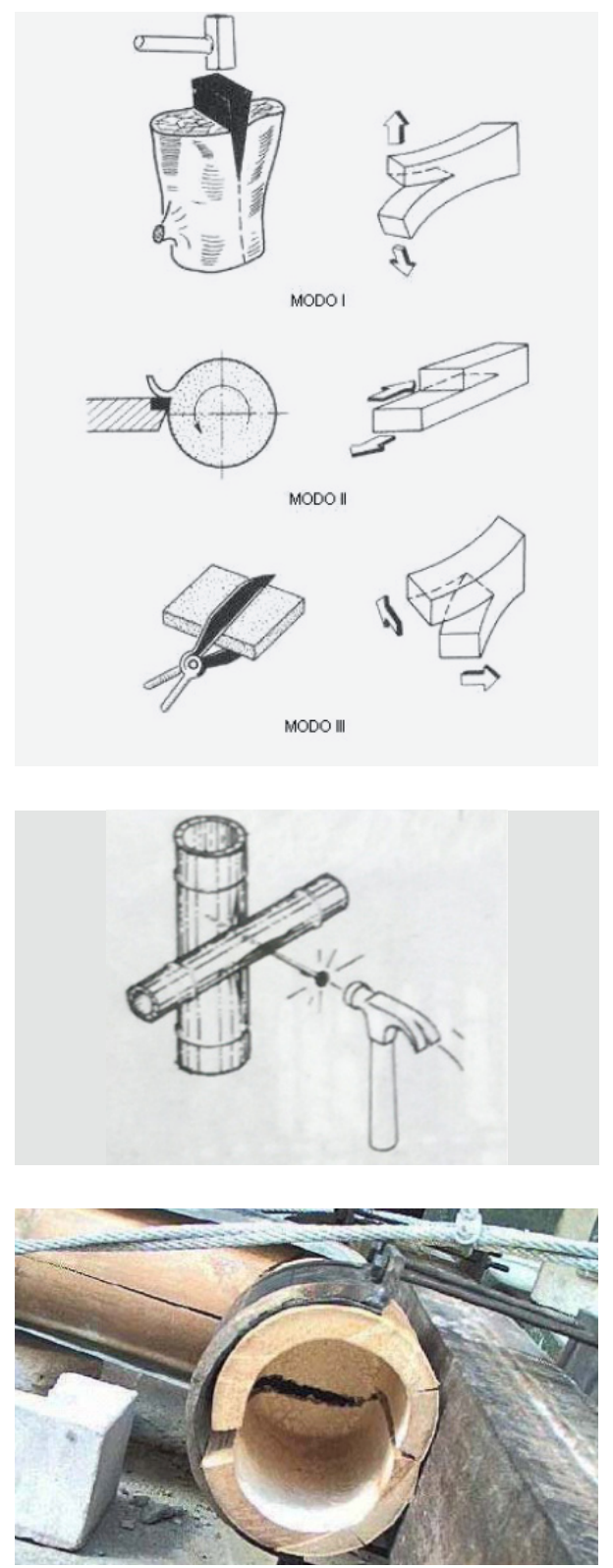

FIGURA 40

Tipos de deslocamento por cisalhamento. Fonte: TASSINI, 2005.

FIGURA 41

Uso de pregos é desaconselhável para conexões. Fonte: HIDALGO-LÓPEZ, 2004.

FIGURA 42

Fratura por compressão perpendicular às fibras. Fonte: TAKEUCHI, 2008. 
dades mecânicas do elemento e, em decorrência, podem prejudicar a estabilidade global do conjunto.

4.4.1.2.2 Esmagamento

O esmagamento se dá quando existe uma carga de compressão perpendicular às fibras que supera a da tensão limite do colmo.

Para evitar o esmagamento quando há cargas concentradas transversais ao eixo axial do bambu, deve-se colocar o colmo para coincidir a carga sobre de um nó ou, no caso de não ser possível preencher a cavidade do internó com alguma peça cilíndrica de madeira ou metálica que se adapte ao vazio, pode-se preencher com graute (Figura 42).

\subsection{2}

Resistência ao fogo

O bambu é um material combustível e deve se proteger para, em caso de incêndio, não seja comprometida a estabilidade da estrutura da qual é parte ou, no mínimo, tenha uma combustão suficientemente lenta para a evacuação dos usuários que ocupem o espaço da edificação. Por ser um material oco, tem pouca massa específica, o que o faz mais vulnerável durante a queima, da seção por combustão pode supor em termos relativos a queima de uma parte muito grande do total de seção (MINKE, 2010).

\subsection{3}

Resistência a movimentos sísmicos

A flexibilidade e a tenacidade do material o caracteriza como um material excelente para resistência dos abalos sísmicos (MINKE, 2010).

Sua estrutura natural o converte em um material excelente para resistir os abalos horizontais originados pelo vento; os movimentos sísmicos são outro tipo de carga horizontal aplicada na base do colmo.

\section{5 \\ Normas}

\subsection{1}

\section{Normas internacionais}

A regulamentação das práticas construtivas é necessária para definir alguns padrões de desempenho aceitáveis e com consenso no grupo que os criou e para quem os criou. Nesse caso, uma normativa para a utilização do bambu é necessária para que seu uso seja disseminado internacionalmente e ampliado localmente.
As normativas servem principalmente para proteger os consumidores, proteger o meio ambiente, reduzir os custos de produção e desperdícios, proteger o trabalhador da construção civil, dar segurança ao usuário e cumprir os requisitos do mercado (JANSSEN, 2000).

Há uma questão socioeconômica que não permite a introdução de materiais de perfil baixo. Essa política dificulta a utilização geral de materiais muito econômicos e muito próximos de populações rurais e de baixa renda.

A primeira norma de bambu foi criada na Índia em 1973 (SOARES, 2013).

As normas técnicas de bambu por organização ou país são as seguintes:

- INBAR - International Network of Bamboo and Rattan ISO 22157-1:2004 Standard for Determination of physical and mechanical properties of bamboo. Descreve como devem ser os ensaios para caraterização das propriedades mecânicas e físicas do material; ISO 22157:2004 Bamboo-Structural Design. Critérios para design e dimensionamento de estruturas feitas de bambu (roliço, processado, laminado);

- Índia - National Building Code of India (P-6) Structural Design, Section 3 timber and bamboo, ca- 
pítulo 3B. Trata o uso de bambu para fins construtivos e estruturas ou elementos estruturais, assegurando a qualidade e efetividade do design e da construção. Possui informações mínimas de resistências e dimensões, plantio, tratamentos, design e técnicas para conexões para estruturas. Essa norma não cobre estados limites de dimensionamento, aborda aspectos gerais da construção e recomendações para o dimensionamento dos elementos estruturais. Diferencia dezesseis espécies de bambus que podem ser utilizados para construção e oferece valores de resistência a flexão, módulo de elasticidade e resistência à compressão, discriminando-os em três grupos segundo as capacidades (SOARES, 2013).

- Califórnia - AC162 do ano 2000, Acceptance criteria for structural bamboo;

- Colômbia - Sociedad Colombiana de Bambú: Norma Técnica Colombiana. A Colômbia é um dos países com uma normativa mais avançada. $\mathrm{O}$ uso do bambu no país está muito disseminado e é uma referência para os arquitetos assim como para órgãos reguladores de outros países para tomar como referência sua legislação na matéria. Possui várias normas técnicas que orientam os diversos setores envolvidos na construção com bambu. TC5300 "Cosecha y postcosecha de los culmos de Guadua angustifolia Kunth"; NTC5301 "Secado e inmunizado de los culmos de Guadua angustifolia Kunth"; NTC5405 "Propagación vegetativa de Guadua angustifolia Kunth"; NTC 5407 "uniones para estructura construidas en Guadua Angustifolia Kunth"; TC 5727 "Terminología de la guadua"; NSR-10 "Norma de Sismo Resistencia no capitulo G12: Estructuras de guadua”. A norma de cálculo de estruturas está incluída na Norma de resistência sísmica para estruturas de madeira;

- Peru - E-100 Bambú. Oficializado em Decreto Supremo 011-2012 pelo presidente da República Peruana. DS-011-2012. Estabelece os princípios técnicos para o design e construção de edifícios sismo resistentes com bambu: G. angustifolia e outras espécies de caraterísticas físico mecânicas semelhantes;

- Brasil - Projeto de Estruturas de Bambu, procedimento, número de referência do documento: ISO/DIS -22156 elaborado pelos prof. Normando Perazzo Barbosa, Khosrow Ghavami e Luiz Eustáquio Moreira. A norma fixa os requisitos básicos exigíveis para projeto de estruturas feitas com colmos de bambu, tratando somente daqueles relativos à resistência mecânica, à trabalhabilidade e à durabilidade das estruturas de bambu (PERAZZO et al., 2010).

4.5.1.1

Norma técnica E100 Bambú

A Norma Técnica E100 Bambú do Peru, desenvolvida em 2011, é uma das mais recentes e toma como referência as normas técnicas colombianas sobre cálculo e design estrutural de bambu guadua (NSR-98) ou a ISO 22156:2004 Bamboo - Structural Design, entre outras. Essa norma, porém, utiliza uma linguagem mais acessível ao público geral e apresenta graficamente muitas soluções e exemplos que fazem dela uma norma muito completa e didática.

A norma se aplica em edificações de até dois andares, e com sobrecargas de uso de $250 \mathrm{kgf} / \mathrm{m}^{2}$.

Critérios de seleção de colmos:

- Só pode utilizar colmos da espécie G. angustifolia;

- Idade dos colmos de 4 a 6 anos;

- Teor de umidade deve ser estar de acordo com o do local onde será instalado;

- Bambus devidamente tratados; 
- Não são admitidas deformações superiores ao $0,33 \%$ de comprimento do colmo;

- Não devem apresentar conicidade superior a $1 \%$;

- Não podem apresentar fissuras perimetrais nos nós nem no eixo neutro do colmo;

- Colmos com rachaduras superiores ao 20\% do comprimento serão descartados;

- Não devem utilizar bambus com algum grau de podridão.

A norma peruana ET100-Bambú (2011) exige que as peças de bambu sejam cortadas de forma a deixar um nó inteiro em cada extremo próximo à conexão, a uma distância máxima $\mathrm{D}=6 \mathrm{~cm}$ da conexão.

Nessa norma, estabelece-se uma série de esforços admissíveis para cálculo estrutural em cada uma das solicitações mecânicas que, comparados com os esforços médios dos colmos apontados capítulo 2, são diminuídos no melhor dos casos aproximadamente quatro vezes. A norma peruana é muito mais restritiva e utiliza valores de tensões admissíveis mais baixos que a colombiana (Tabelas 1 e 2).

Estabelecem-se coeficientes de segurança da ordem de 4, sendo que os coeficientes de segurança do aço pectivamente. A variabilidade das propriedades ao longo do colmo faz com que sejam necessários altos coeficientes que, na flexão, por exemplo, chega a ser de 25 .

Mostra exemplos gráficos de como executar soluções construtivas de todos os componentes estruturais de um edifício simples com bambu, e quais requisitos tem que cumprir cada um dos componentes

Para as uniões construídas que não estejam especificadas na norma, o profissional responsável da obra deverá comprovar a estabilidade da solução por meio de cálculos.

No caso das estruturas de cobertura, os elementos portantes deverão conformar um conjunto estável para cargas laterais e verticais. Exige-se que a cobertura seja leve e que os materiais da cobertura garantam a impermeabilidade para proteger os bambus da umidade, e beirais maiores de 60 $\mathrm{cm}$ deverão ter apoios adicionais quando não forem justificados estruturalmente.

Essa norma faz referência a especificações de materiais complementares que podem ser utilizados, como madeira, concreto e metais e outros, para terem uma boa ligação com o bambu. 


\begin{tabular}{|c|c|c|c|c|}
\hline Flexão (Fm) & $\begin{array}{l}\text { Tração } \\
\text { Paralela (Ft) } \\
\end{array}$ & $\begin{array}{l}\text { Compressão } \\
\text { Paralela (fc) }\end{array}$ & Cisalhamento (fv) & $\begin{array}{l}\text { Compressão } \\
\text { Perpendicular }\left(f^{\prime} c \perp\right) \\
\end{array}$ \\
\hline $5 \mathrm{MPa}\left(50 \mathrm{~kg} / \mathrm{cm}^{2}\right)$ & $16 \mathrm{MPa}\left(160 \mathrm{~kg} / \mathrm{cm}^{2}\right)$ & $13 \mathrm{MPa}\left(130 \mathrm{~kg} / \mathrm{cm}^{2}\right)$ & $1 \mathrm{MPa}\left(10 \mathrm{~kg} / \mathrm{cm}^{2}\right)$ & 1,3 MPa $\left(13 \mathrm{~g} / \mathrm{cm}^{2}\right)$ \\
\hline Flexão (Fm) & $\begin{array}{l}\text { Tração } \\
\text { Paralela (Ft) }\end{array}$ & $\begin{array}{l}\text { Compressão } \\
\text { Paralela (fc) }\end{array}$ & Cisalhamento (fv) & $\begin{array}{l}\text { Compressão } \\
\text { Perpendicular }\left(f^{\prime} c \perp\right)\end{array}$ \\
\hline $15 \mathrm{MPa}\left(150 \mathrm{~kg} / \mathrm{cm}^{2}\right)$ & ) $18 \mathrm{MPa}\left(180 \mathrm{~kg} / \mathrm{cm}^{2}\right)$ & $14 \mathrm{MPa}\left(140 \mathrm{~kg} / \mathrm{cm}^{2}\right.$ & 2) $1,4 \mathrm{MPa}(10 \mathrm{~kg} / \mathrm{cm}$ & $\left.\mathrm{n}^{2}\right)$ 1,3 $\mathrm{MPa}\left(12 \mathrm{~g} / \mathrm{cm}^{2}\right)$ \\
\hline
\end{tabular}




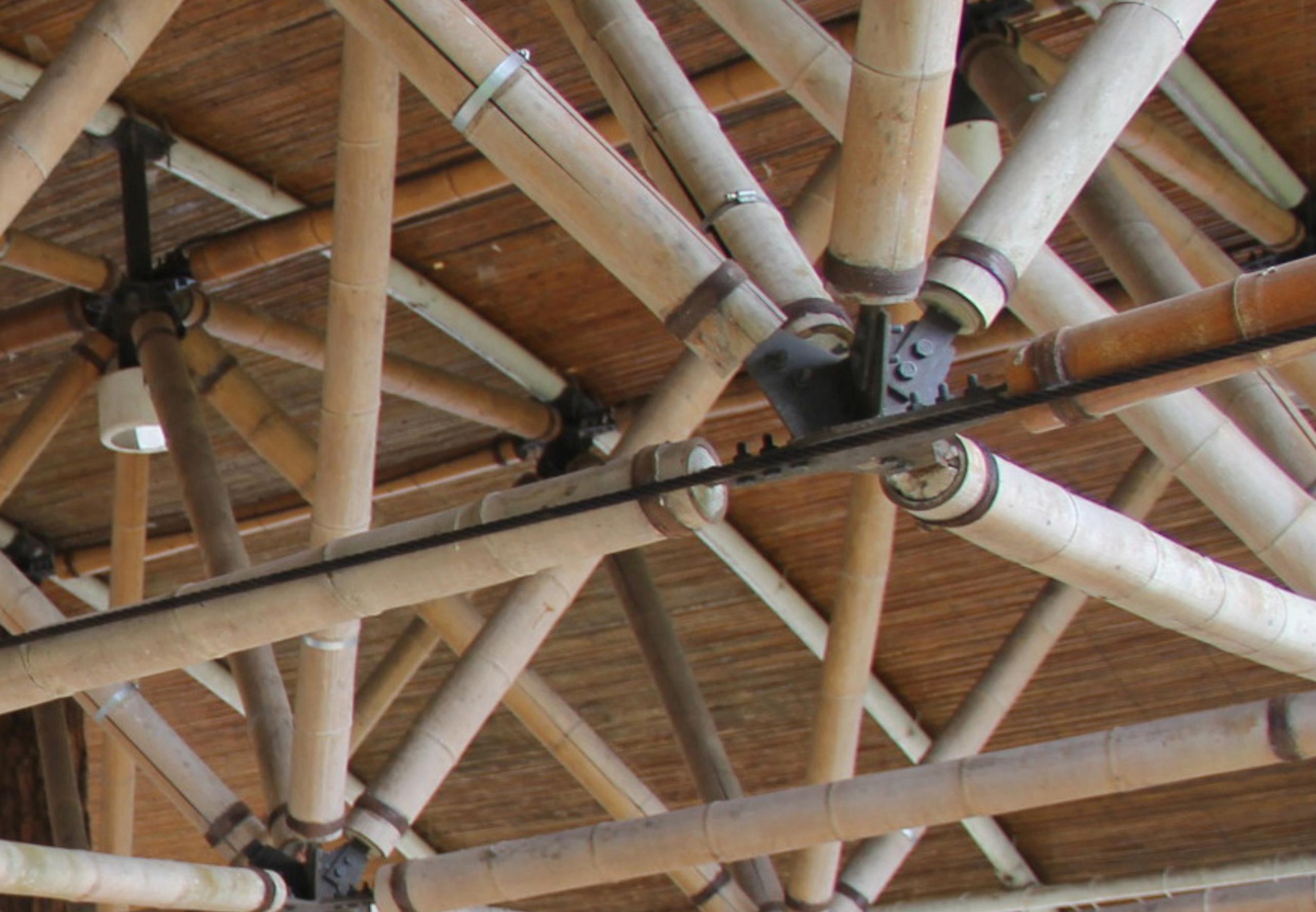




\section{Capítulo 5}

\section{Estudos de Caso}

5.1

\section{Avaliação das patologias em estruturas de bambu}

A construção de um edifício possui diversas etapas em que vários agentes e fatores intervêm e influenciam nas caraterísticas, resultados e desempenho do edifício.

Os erros e as falhas nos processos da construção são inerentes ao envolvimento direto dos humanos. Os vícios se traduziram, no futuro, em alguns comportamentos disfuncionais de partes da edificação, chamados de patologias - à semelhança das disfunções nos organismos vivos.

É necessário o estudo das ocorrências patológicas que se manifestam nos edifícios e estudar seus sintomas, consequências e, sobretudo, as origens para aperfeiçoar os processos envolvidos na construção civil, para aprimorar um dos setores mais arcaicos e menos desenvolvidos da sociedade produtiva.
Segundo Grandinski (2011 apud SANTOS, 2014), há uma série de fatores originários de patologias, dependendo da sua relação com o edifício. As de origem exógena, isto é, causas com origem fora da obra, produzidas por terceiros ou pela natureza, e as causas de origem endógena, que são inerentes aos processos da própria edificação, desde a concepção, a fabricação dos materiais, a execução do projeto concebido com os materiais fabricados, e finalmente o uso da obra executada. Finalmente, as causas de origem natural, que podem ser falhas previsíveis ou imprevisíveis, evitáveis ou inevitáveis conforme o caso, como movimentos sísmicos, chuvas ou ventos anormais, que até certo ponto têm de ser previstas na fase de projeto, com alguns coeficientes de segurança elevados para se antecipar a riscos dessa natureza.

Outra classificação relativa às origens patológicas feita por Arriaga $e t$ al. (2009) para estruturas de madei- 
ra estabelece que podem ocorrer por três motivos:

- agentes bióticos;

- agentes abióticos (agentes atmosféricos);

- anomalias estruturais.

Com base na classificação de Brito (2014) - e adaptando às estruturas de bambu -, pode-se estabelecer que existem os seguintes fatores responsáveis pela deterioração do material:

\section{Agentes bióticos}

- Fungos

- Fungos manchadores

- Fungos emboloradores

- Fungos apodrecedores

- Fungos de podridão parda

- Fungos de podridão branca

- Insetos

- Fungos de podridão mole

- Térmitas isópteras (cupins)

- Carunchos

- Insetos xilófagos (vespas)
Agentes abióticos

- Agentes físicos

- Patologias de origem estrutural

- Instabilidade

- Remoção de elementos estruturais

- Fraturas incipientes

- Movimentos de nós, distorções

- Deformações, deslocamentos e flechas

- Presença de defeitos naturais

- Danos mecânicos

- Danos por animais silvestres

- Danos por vandalismo

- Agentes químicos

- Corrosão em ligações

- Efeito da corrosão no bambu

- Agentes atmosféricos

- Ação da luz ultravioleta

- Intemperismo

- Danos por inchamento e retração do bambu

- Ações de vento nas estruturas

- Raios atmosféricos
- Danos devidos ao fogo

Brito (2014) também expõe as causas de patologias endógenas do edifício, aquelas inerentes às estruturas e à sua existência material.

Causas por falhas humanas

- Ausência ou falhas de projetos estruturais

- Ausência de mão-de-obra qualificada e/ou falhas em práticas da construção

- Utilização incorreta dos materiais de construção

- Resistências inferiores às especificadas. Neste caso, o bambu não tem normativa no Brasil nem de produção nem na execução, portanto, o fornecedor não tem responsabilidade sobre os valores de resistência mecânica do bambu fornecido, sendo responsabilidade do projetista garantir, por meio dos testes de resistência, a estabilidade estrutural do material. 
- Ausência de tratamento preservativo. Tratar o bambu depende do fornecedor, ou eventualmente do executor da obra.

- Falhas no processo de tratamentos preservativos. São necessárias algumas garantias mínimas para um bom desempenho do tratamento preservativo e sua aplicação correta

- Solo com caraterísticas diferentes.

- Deficiências nas ligações

- Tipo de ligações diferentes das especificadas

- Diâmetros inferiores aos especificados. O bambu é um material que não é processado geometricamente, então, existe muita variabilidade e é preciso levar em consideração as variáveis e excentricidades, além de fazer cálculos e detalhamentos com tolerâncias muito altas.

- Resistências inferiores às especificadas. É necessário controle de qualidade dos agentes envolvidos na obra para que se cumpram as especificações de projeto.

- Deficiência no transporte material por parte do fornecedor e fiscalização rigorosa do executor.

- Falhas humanas durante a utilização

- Ausência de manutenções periódicas e/ou medidas preventivas.

- Manutenções corretivas inadequadas e/ou ineficientes

- Causas naturais. Essas causas podem ser previsíveis ou imprevisíveis, porém, é responsabilidade de projeto auferir as condições necessárias para que essa aleatoriedade não afete a estrutura de bambu. Só quando existe algum fenômeno natural extraordinário de dimensões não controláveis que os projetistas estão isentos de responsabilidade.

- Ação de agentes bióticos

- Presença de umidade

- Temperatura adequada

- Oxigênio

- Fonte de alimento disponível

- Ação de agentes abióticos

- Causas químicas

- Causas físicas

Causas com origem externa ao corpo estrutural constituem o outro grupo. Brito (2014) as classifica da seguinte forma:

- Falhas humanas durante o projeto - Ausência de projetos estrutu- rais. É necessário um profissional qualificado que conheça as idiossincrasias do bambu para garantir estabilidade do conjunto

- Ausência de profissional especialista na área

- Inadequações na escolha da categoria de uso ao ambiente

- Falha na concepção de projeto e /ou modelação estrutural inadequada

- Avaliações inadequadas das cargas e ações

- Detalhamentos inadequados e/ou insuficientes

- Ausência de sondagens de solo

- Inadequações nas interações solo-estrutura

- Falhas entre integrações dos projetos complementares

- Falhas humanas durante a utilização

- Alterações estruturais

- Mudanças do tipo de utilização parcial ou total do edifício

- Sobrecargas excedidas

- Alterações nas condições do terreno e/ou fundações

- Ações mecânicas

- Choques de veículos

- Recalque de fundações

- Abrasão mecânica

- Ações atmosféricas

- Intemperismo 
- Isolamento excessivo

- Atuação constante de presença de água

- Variações de temperatura

- Ações de enchentes

- Ações químicas

- Acidente com tombamentos de veículos

- Reações de tratamentos preservativos com materiais diferentes nas ligações

- Ações biológicas

- Presença de agentes bióticos na região ou nas vizinhanças

Este capítulo apresenta dois estudos de caso em que são identificadas algumas manifestações patológicas presentes em estruturas de bambu e tenta-se dar uma resposta sobre suas origens. É importante averiguar em qual das etapas ocorreu o vício como medida para dar um retorno e melhorar a construção com bambu, considerando-se que pode se dar o caso de serem vários agentes envolvidos por uma sequência de falhas. É importante prescrever uma remédiação para resolver a patologia do objeto de estudo atual, mas é importante indicar a origem como medida preventiva para futuras obras com bambu.

O objetivo deste levantamento é, com base nos objetivos preestabelecidos por Bonamini (1995):
- Obter informações qualitativas sobre a resistência e adequação das soluções arquitetônicas das conexões;

- Registrar os diferentes tipos de não conformidades e quais seriam suas necessidades de reabilitação, para um desempenho correto;

- Avaliar quais fatores afetaram a estrutura para correção dos riscos com o intuito de não possibilitar a aparição novamente;

- Contribuir na identificação do comportamento estrutural, já que as estruturas de bambu são uma novidade e não há muitas referências nem muitos estudos do seu comportamento ao longo do tempo.

Cabe destacar que o bambu, apesar de ser utilizado desde muito tempo atrás em ambientes rurais e indígenas, é um material relativamente novo na arquitetura contemporânea, e não há parâmetros normatizados no Brasil que determinem as caraterísticas do material e da sua colocação em obra, legislando-o para um controle de qualidade rigoroso.

\subsection{1}

\section{Escolha dos estudos de caso}

Para a escolha dos exemplos a serem estudados, foi estabelecida uma série de recortes e restrições, de acordo com as intenções da pesquisa e as limitações técnicas e contextuais:

1) Como recorte geográfico, foi selecionado o território nacional brasileiro, a fim de facilitar as visitas e o contato com os criadores pela proximidade. Dessa maneira, trata-se de entender se existem critérios e proposições construtivas ou estéticas novas e originais do país. Para fazer este levantamento, foram utilizados como referência os estudos de Ruggiero (2015), no qual se faz uma catalogação das obras brasileiras em que é utilizado o bambu e que tem uma relevância do ponto de vista arquitetônico.

2) Realizou-se um recorte cronológico no qual foram descartadas todas aquelas obras constituídas depois de 2010. A necessidade de as construções terem uma certa idade e um tempo de uso é importante para que possam ter aparecido patologias reconhecíveis, principalmente de tipo estrutural, que são as que demoram mais em se manifestar e que são o objeto principal desta pesquisa.

3) Foram escolhidas obras em que a utilização do bambu é intensiva e na sua forma natural roliça para conformar a estrutura.

4) Selecionadas as obras com estruturas nas quais os sistemas construtivos fossem idealizados como 
um nível tecnológico pertencente ao grupo $3^{1}$, para que o resultado do detalhamento e das conexões estivesse voltado à necessidade de processos industrializados como suporte.

5) Foi definido também o uso estrutural para cobertura, limitando o tipo de ações de uso. Havendo só cargas acidentais por vento, e, portanto, como cargas permanentes apenas o peso próprio da cobertura e da estrutura em si.

6) As estruturas deveriam ser todas visíveis sem necessidade de equipamentos especiais nem de prospecção invasiva para poder fazer uma avaliação precisa e poder controlar todo tipo de manifestação patológica que pudesse aparecer nos colmos.

7) Foram escolhidos edifícios com sistemas estruturais diferentes: um de vetor-ativo puro e outro que fosse híbrido.

As escolhas finais foram:

1) A sala de diálogos de verão da Amana Key em Cotia, no estado de São Paulo, do escritório Amima Arquitetura da arquiteta Leiko Motomura, com cálculo estrutural do Natan Levental.

2) Centro Cultural Max Feffer em Pardinho, no estado de São Pau- lo, do mesmo escritório e do mesmo calculista.

As duas obras são arquitetônica e estruturalmente muito interessantes, principalmente o Centro Cultural. Mas é muito enriquecedor que ambas as obras sejam do mesmo autor, para comprovar a evolução e maturação técnica no uso do material e saber quais referentes orientaram a construção da Amana Key (2003) e quais princípios construtivos nortearam a concepção do Centro cultural 5 anos depois da primeira experiência, tentando melhorar aqueles pontos negativos que pudessem haver ocorrido na primeira estrutura.

\subsection{2}

\section{Metodologia}

A metodologia escolhida para analisar o desempenho das estruturas de bambu foi feita a partir da sugerida pela ISO 13822:2010 Bases for design of structures - Assessment of existing structures.

O fluxograma para avaliação de estruturas existentes da ISO 13822:2010, traduzido por Brito (2013), mostra as diferentes fases da análise (Figura 1).

A avaliação é feita por meio da investigação pela documentação e inspeção. Também é feita uma aná- lise estrutural primária, modelando em STRAP (Structural Analysis Programs). Uma verificação cruzando informações da análise, conferindo falhas mecânicas por meio dos resultados obtidos nos modelos de cálculo. E, finalmente, uma proposta de intervenção com base na avaliação. Todas essas etapas são permeadas pela revisão bibliográfica feita nos capítulos anteriores.

A metodologia usada é:

1) Levantamento arquitetônico, construtivo e estrutural do projeto

- Desenho das plantas cortes e elevações;

- Modelagem tridimensional da estrutura e das conexões:

- Modelagem tridimensional para análise estrutural.

2) Inspeção visual

- Etapa em que se realizaram visitas nas obras objeto de estudo para inspecionar e identificar manifestações patológicas que existiam na estrutura de bambu e determinar visualmente suas origens. É uma inspeção preliminar de nível 1, segundo Bonamini (1995). É feita uma avaliação geral, com o intuito de dar uma ideia geral das patologias que afetam a estru- 
tura. São mostradas diversas patologias, mas de um modo qualitativo, detalhando cada uma delas; não serão mostradas patologias com manifestações e origens semelhantes, mas em posições diferentes. $\mathrm{O}$ objetivo é dar uma visão geral de diferentes tipos de falhas que podem ocorrer na estrutura, e não enumerar cada uma individualmente.

3) Catalogação de tipologias patológicas, apresentando-as por meio das seguintes fases

- Descrição por inspeção visual

- Exigência do usuário afetado

- Causa provável

- Mecanismo de ocorrência

- Proposta de solução

O bambu tem uma durabilidade relativamente baixa se comparada com os demais materiais convencionais para estruturas.

É importante que os projetistas tomem consciência e projetem edifícios com estruturas de bambu tendo muito presentes os conceitos de manutenção, sobretudo os de manutenção preventiva, para assim projetar estruturas que facilitem a substituição a cada certo intervalo de tempo dos colmos de bambu.

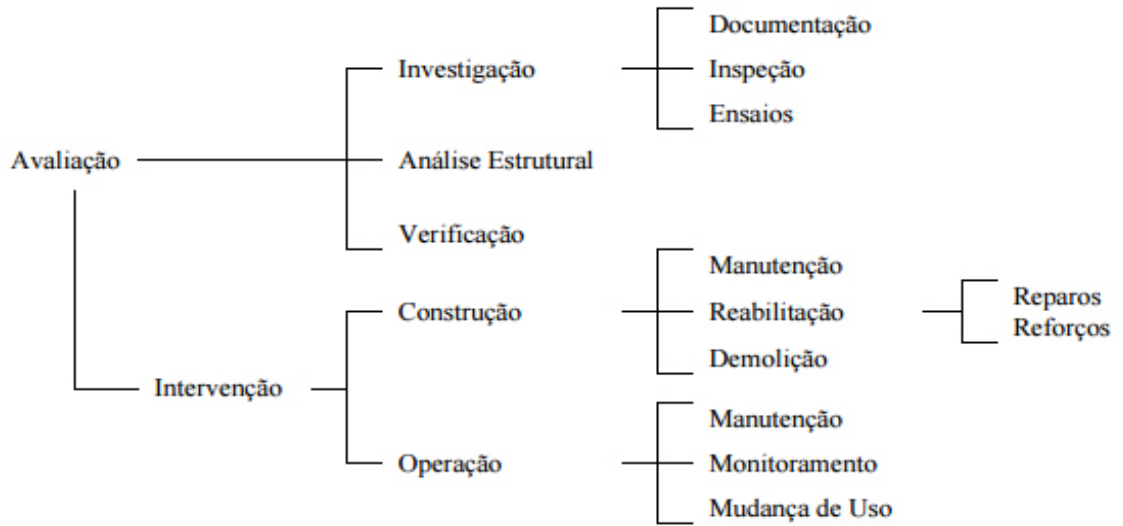

FIGURA 1

Fluxograma para avaliação de estruturas existentes. Fonte: BRITO, 2013 
5.1.3

Exigências do usuário

As exigências dos usuários estão estabelecidas com base na norma NBR 15.575 (2013). Cabe também explicitar que essa norma é para edifícios habitacionais, mas pode-se extrapolar alguns dados e usá-la como referência.

Três grupos com suas subdivisões classificam as exigências:

1) Fatores relativos à segurança

- Segurança estrutural

- Segurança contra o fogo

- Segurança no uso e na operação

2) Fatores relativos à habitabilidade

- Estanqueidade

- Desempenho térmico

- Desempenho acústico

- Desempenho lumínico

- Saúde, higiene e qualidade do ar

- Funcionalidade e acessibilidade

3) Fatores relativos à sustentabilidade

- Durabilidade

- Manutenibilidade

- Impacto ambiental

Ao avaliar o desempenho do sistema estrutural em bambu, busca-se analisar a adequação em uso deste sistema construtivo e se cumpre a função pela qual foi destinado.

Para a avaliação de desempenho material predominante, exige-se um conhecimento profundo sobre o material e as técnicas construtivas, além do conhecimento das exigências dos usuários e as condições de uso do edifício no qual é inserido o sistema estrutural analisado.

O objeto de estudo é a estrutura, portanto há muitos menos requisitos dos usuários a serem cumpridos.

A estrutura de bambu da cobertura, objeto deste estudo, ao estar situada no primeiro andar, não tem contato com a umidade que provém do solo. Porém, a umidade proveniente da chuva é de interesse primordial, e este estudo não busca analisar o telhado da cobertura, mas, de certa forma, há decisões tomadas pelos intervenientes que podem afetar as caraterísticas e propriedades do sistema estrutural, e que aqui foram consideradas. Uma incorreta estanqueidade com a consequente exposição dos elementos estruturais de bambu à água, acarreta uma degradação acelerada e um desempenho inadequado de parte ou da totalidade do sistema - degradação que, como consequência, afetará a durabilidade da estrutura.

A durabilidade do bambu é um requisito essencial para valorizar a conveniência do material perante solicitações mecânicas com grandes esforços para sistemas estruturais. A degradação causada por agentes ambientais e biológicos, se controlada, não pode ser um obstáculo para utilização desde que haja uma previsão consciente das ações que existirão durante a vida útil do edifício e que, em projeto, haja um planejamento de como essas ações preventivas ou corretivas serão concretizadas.

O desempenho da estrutura em relação à sua durabilidade está previsto em fase de projeto, com tratamentos químicos para a estrutura com periodicidade anual, assim como a conceituação de uma estrutura superdimensionada para permitir a troca de barras isoladas sem comprometer a estabilidade do conjunto. Uma durabilidade baixa, combinada com uma péssima ou inexistente manutenção, afetará diretamente a estabilidade estrutural do sistema.

Um bom desempenho estrutural se caracteriza pela impossibilidade de o sistema chegar ao estado-limite de serviço. Mas, como já frisado, não existe norma brasileira para análise do projeto estrutural de bambu. As outras normas não são aplicáveis a projetos em que o elemento resistente principal são colmos de bambu.

Haverá considerações sobre as condições ambientais que puderem influir no projeto, como exposição às 
intempéries e tentativa de proteção do sistema e de suas partes de agentes degradantes.

O bambu apresenta quase sempre como manifestação patológica da incorreta transmissão de cargas, fendas e rachaduras no direção longitudinal do colmo. As trincas na estrutura são as manifestações patológicas mais importantes, segundo Thomaz (1989), por causa de três aspectos fundamentais: o aviso de um eventual colapso da estrutura, o comprometimento do desempenho da obra em serviço (durabilidade, ataques biológicos) e o constrangimento psicológico que a fissuração do edifício exerce sobre o usuário.

Ao avaliar o desempenho do sistema estrutural em bambu, busca-se analisar a adequação ao uso desse sistema construtivo e se o mesmo cumpre a função a qual foi destinado. 
5.2

Estudo de caso: Amana Key Sala

de Diálogos de Verão

FIGURA 1

Sala diálogos de verão Foto: Joan Font.

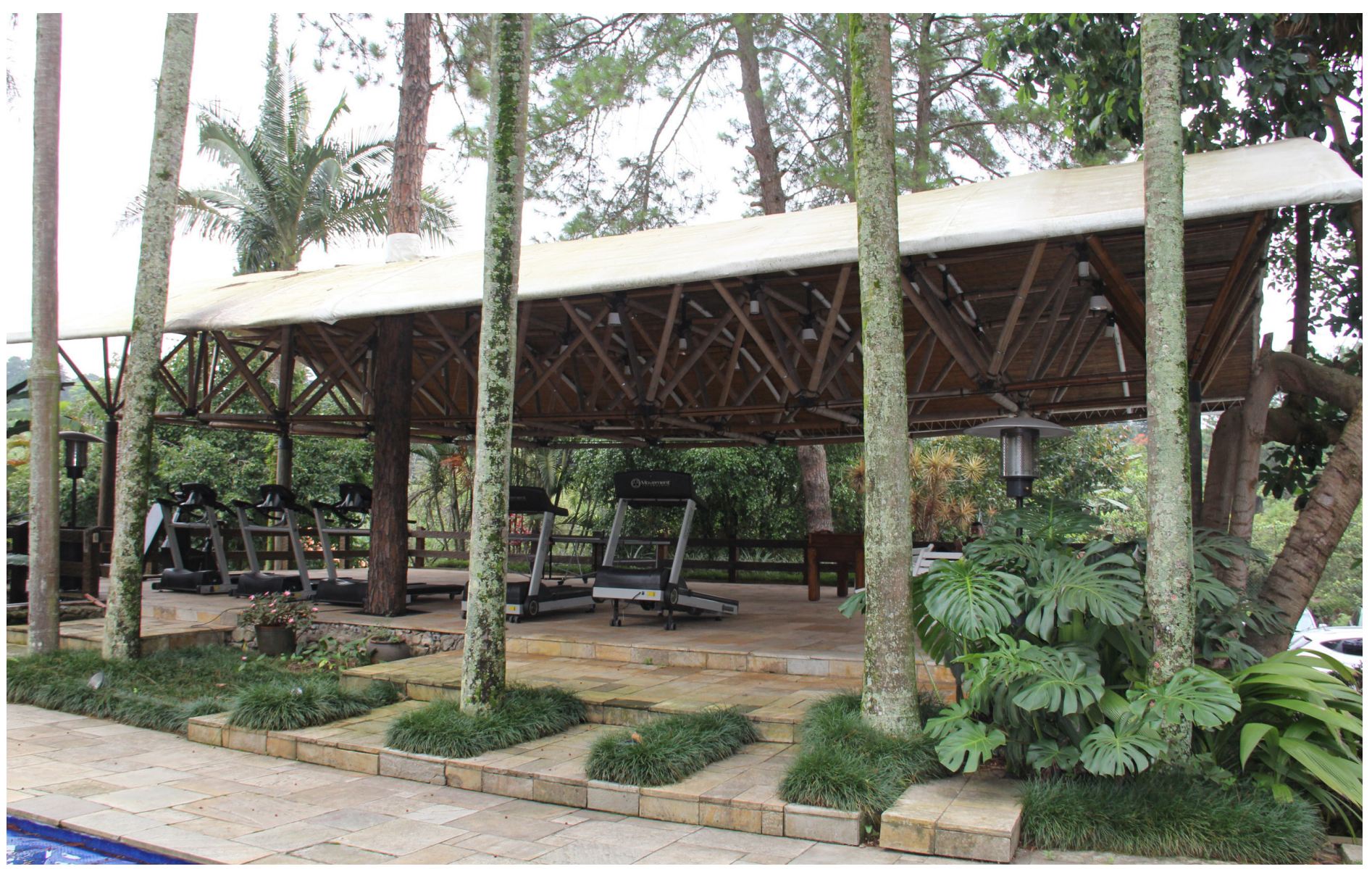


Localização: R. Nova América, 84 Granja Viana, Cotia (SP)

Arquitetura: Amima Arquitetura

(Leiko Hama Motomura)

Estrutura: Njl Engenharia e Projetos

S/C (Natan Jacobsohn Levental)

Ano do projeto: 2003

Ano de conclusão da obra: 2003

Área construída de piso: $150 \mathrm{~m}^{2}$

Área construída de cobertura:

$238 \mathrm{~m}^{2}$

\section{2 .1}

0 projeto de arquitetura

A Sala de diálogos de verão (Figura 1) é uma pequena cobertura construída dentro do terreno particular da instituição Amana Key. O projeto tinha como premissa do cliente refletir o caráter inovador e sustentável da instituição.

O projeto tenta se integrar no contexto natural existente no sitio por meio da leveza do sistema estrutural, e pela utilização de materiais de baixo impacto ambiental.

Para o material resistente que iria compor a estrutura espacial foi escolhido o bambu, para exemplificar essa mudança de paradigma construtivo e de mentalidade.

A escolha foi devida às muitas vantagens desde o ponto de vista da sustentabilidade e da resistência mecânica que o bambu possui.

Outras ações de projeto que visavam a utilização de materiais e sistemas amigáveis com o meio ambiente, foram o uso de pilares de madeira roliça de reflorestamento, o sombreamento com bambu tipo "vara-de-pescar" e lâmpadas de alta eficiência e baixo consumo. 


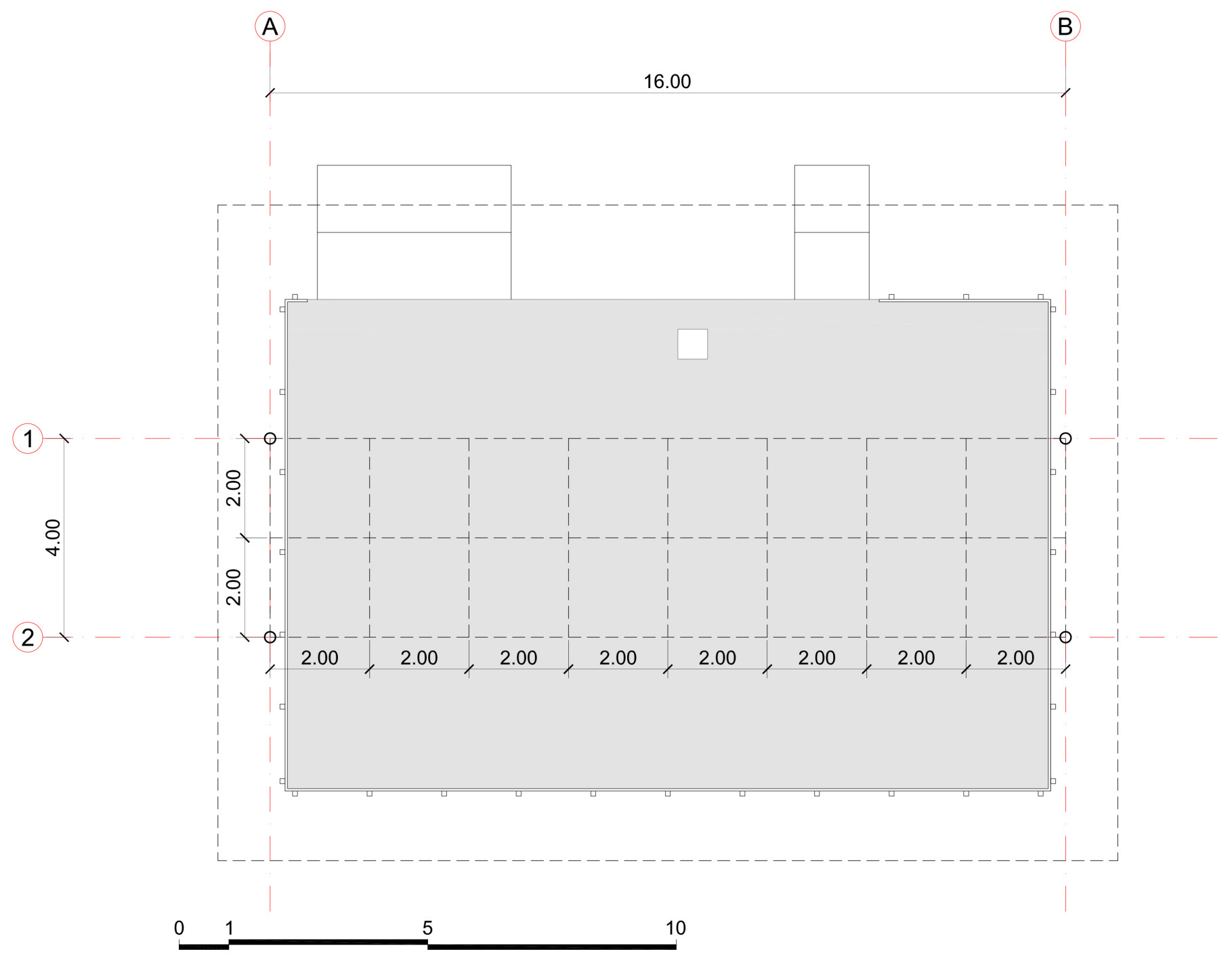

Planta do térreo. 


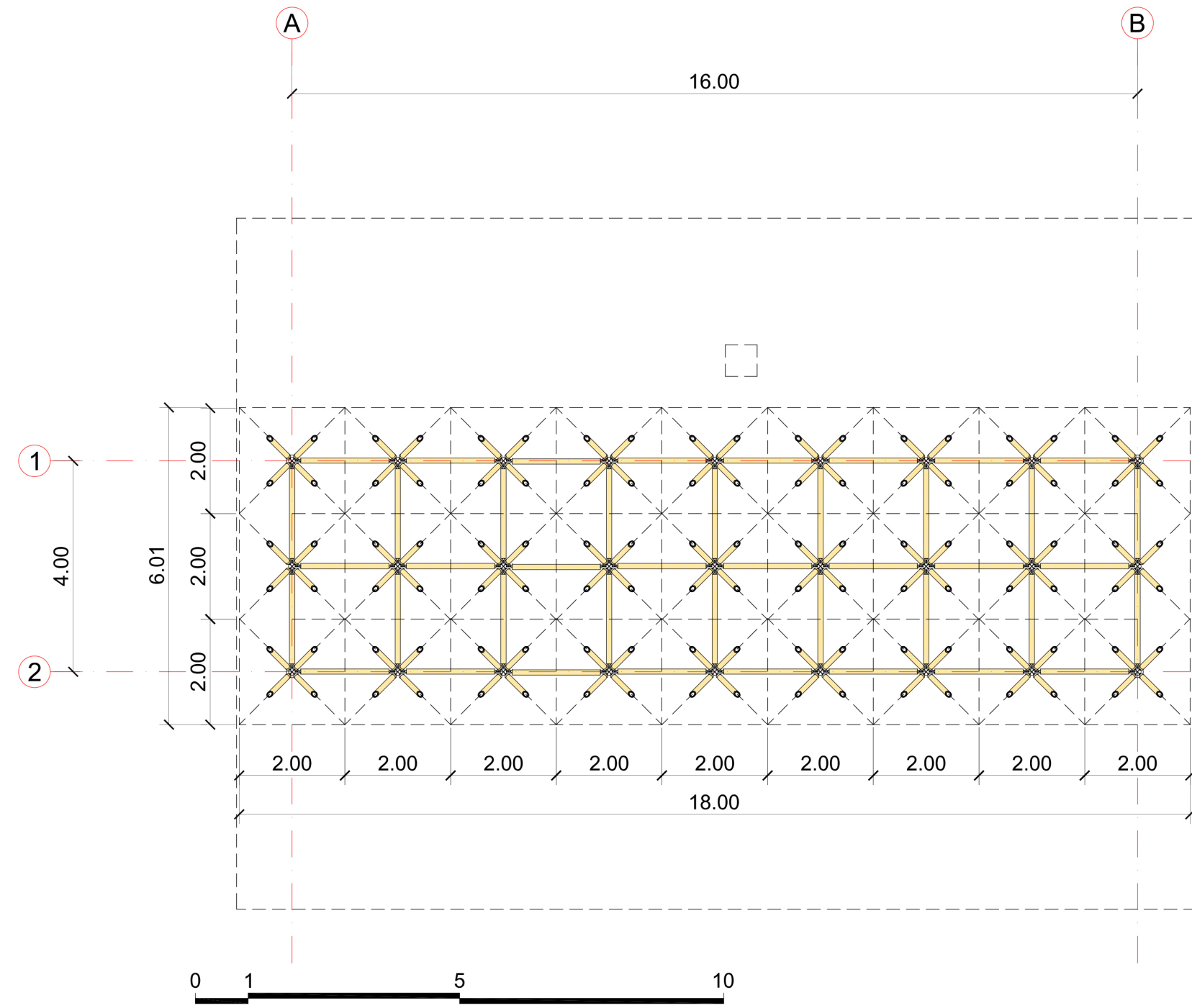

FIGURA 3

Planta seccionada. 


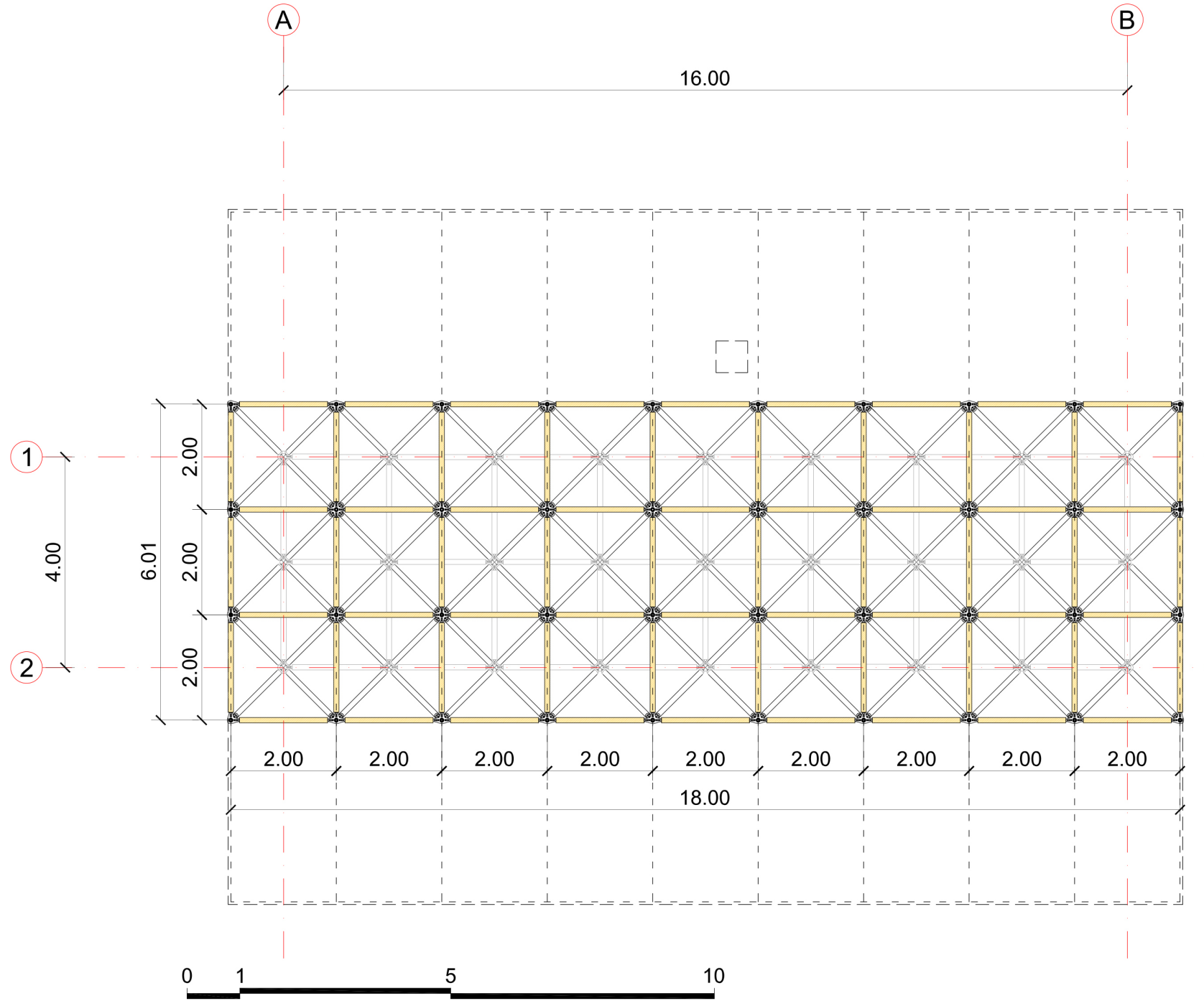

FIGURA 4 


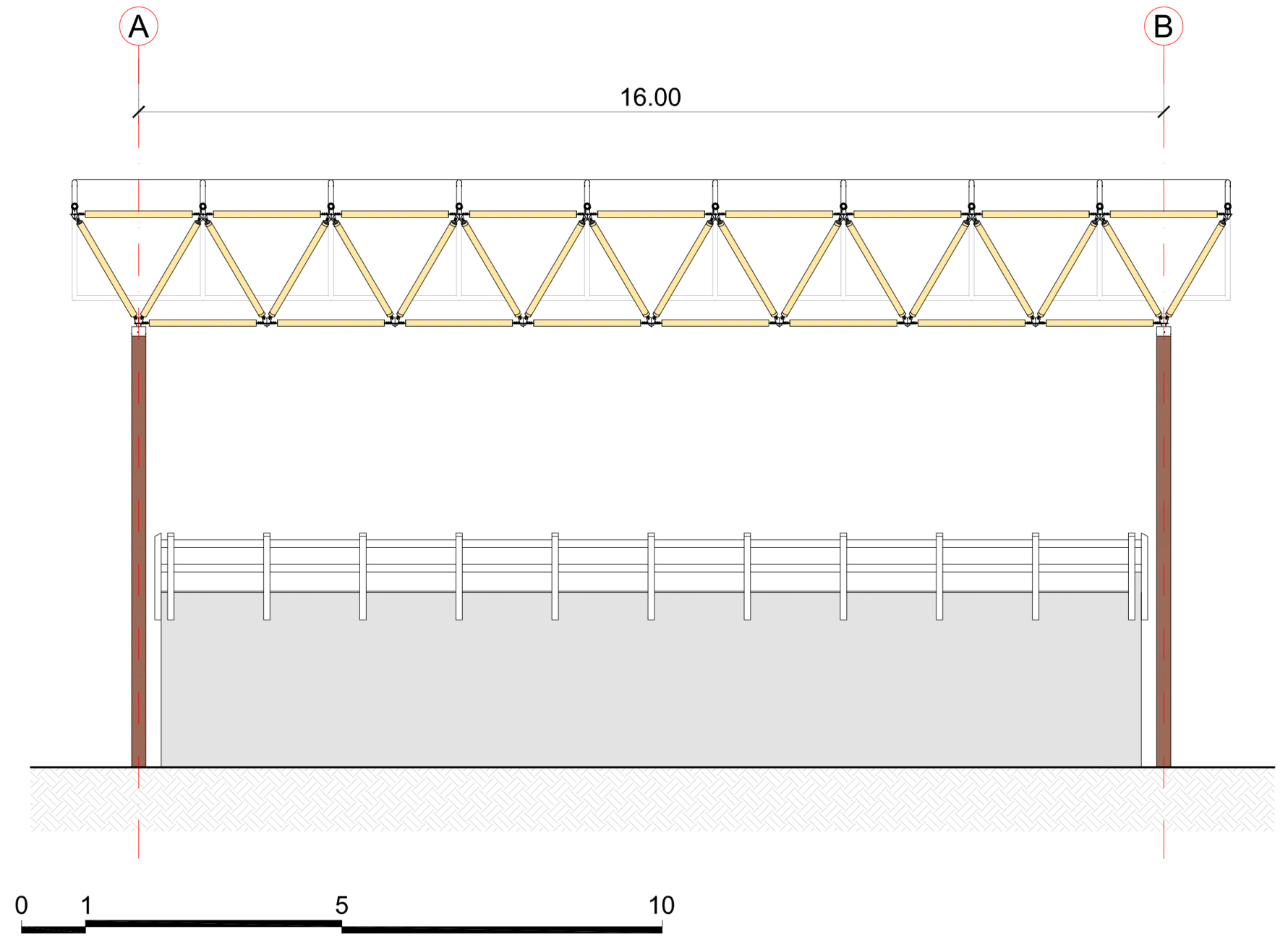

FIGURA 5

Elevação longitudinal.

133 


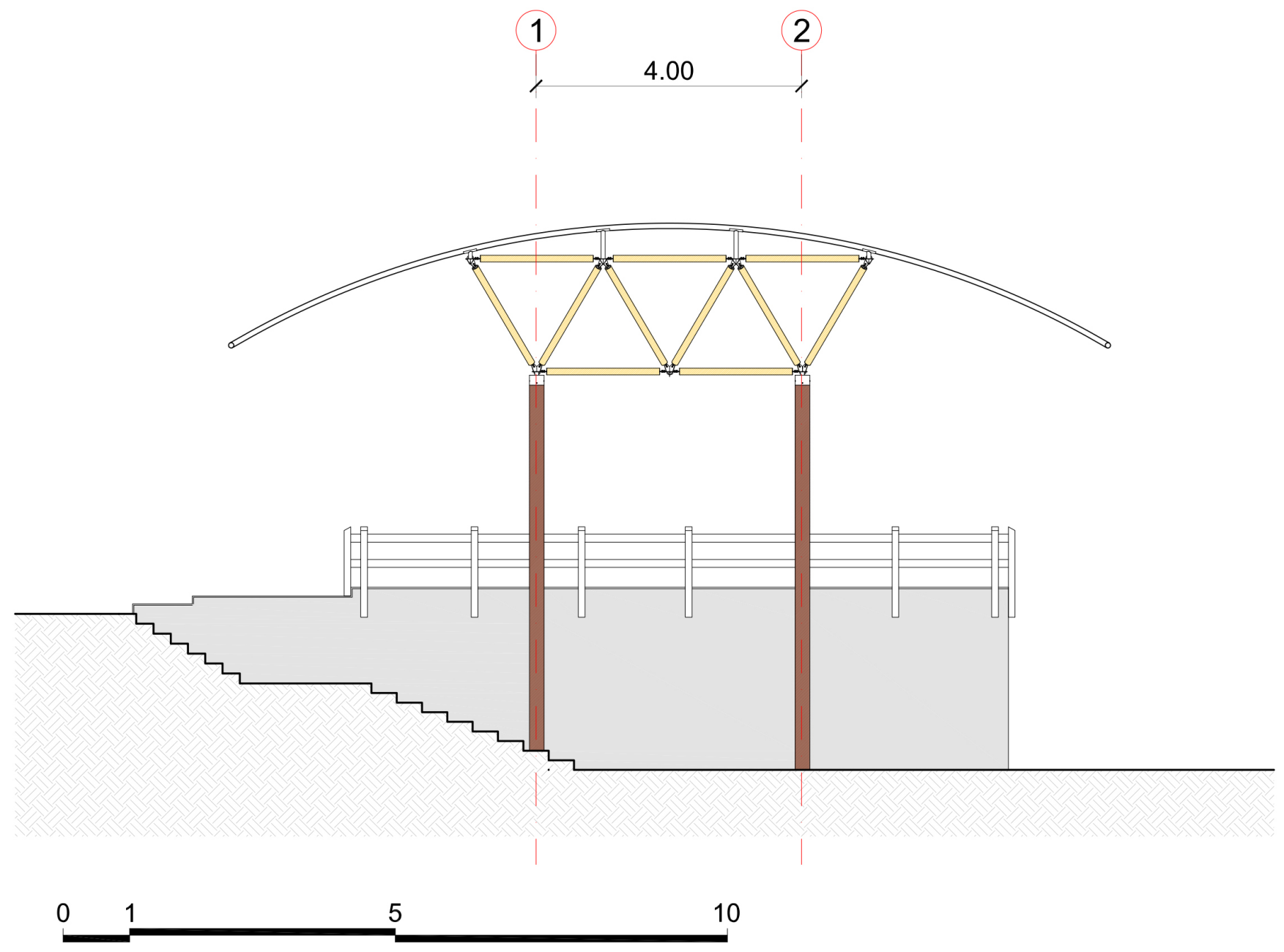

FIGURA 6

Elevação transversal. 


\subsubsection{A cobertura com estrutura de bambu}

A estrutura está composta por quatro pilares roliços de madeira de eucalipto, que definem um retângulo de 4 m x 16 m entre eixos estruturais. A cobertura em forma de abóboda projeta no solo um retângulo de 13,20 m x $18,10 \mathrm{~m}$, dando um total de $238 \mathrm{~m}^{2}$ de superfície coberta.

Sobre dos pilares está apoiada a treliça feita de colmos de bambu e conexões metálicas. Esta tipologia estrutural é catalogada como sistema de vetor-ativo por Engel (2001) e é um sistema de treliça espacial plana de duas capas composta por semioctaedros.

A capa superior é criada por uma malha quadriculada formando 16 semioctaedros. A capa superior é formada por 30 semioctaedros. A estrutura no total é composta por 216 colmos de bambu, 108 deles com um comprimento de $2 \mathrm{~m}$ formando as malhas superior e inferior e 108 colmos com comprimento de 2,20 m que unem os nós da malha superior com os nós da malha inferior.

Existe um cabo de aço que funciona como tirante, que segura as conexões sobre os 4 pilares para evitar o deslocamento horizontal destes pontos.

As conexões são metálicas, todas com o mesmo critério de design sendo modificadas segundo a posição na estrutura. A parte de vedação é sustentada por arcos tubulares de $10 \mathrm{~cm}$ de diâmetro com uma curvatura com um raio de aproximadamente $13 \mathrm{~m}$. Os arcos têm quatro pontos de apoio que repousam sobre as conexões da malha superior. Há um total de 10 arcos que estão unidos em cada extremo por outra barra tubular metálica.

Em cima dos arcos metálicos uma esteira de bambus da espécie Phyllostachys sp serve como forro, em cima do forro há uma lona translúcida impermeável que protege a estrutura da exposição à chuva.

Os bambus utilizados para a estrutura são da espécie Phyllostachys heterocycla, que foram tratados com cozimento no vapor de água. Um tratamento ecologicamente correto, mas com uma efetividade um pouco baixa comparado com os tratamentos que, além de removerem o amido, impregnam os bambus de substâncias tóxicas para os agentes biológicos.

Cada colmo de bambu tem duas barras de aço que se insertam $60 \mathrm{~cm}$ dentro do colmo por cada um dos seus extremos, deixando uma parte exposta para a fixação na conexão metálica com parafusos. Visando enrijecer o conjunto das barras metáli- cas com os colmos de bambu foram preenchidas as cavidades com graute. Para evitar trações radiais nos extremos dos colmos, foram colocadas braçadeiras de arame recozido que comprimem radialmente os colmos.

A partir de uma análise das deformações básico da estrutura com o programa de cálculo STRAP (Figura 8), observou-se que:

- As deformações maiores na estrutura como um todo acontecem nos arcos metálicos;

- Os deslocamentos maiores na estrutura de bambu acontecem nas barras centrais entre os eixos A-B;

- Os maiores esforços axiais ocorrem nas barras horizontais da capa superior na direção nos eixos 1 e 2 na região central do vão A-B;

- Dentre as barras de bambu, as diagonais perto dos colmos são as que sofrem maiores momentos fletores;

- Nas combinações por sucção da carga de vento, a forção de sucção é maior que o peso próprio da estrutura e do telhado.

Foram identificadas diferentes colorações nos colmos. Aqueles com tons mais saturados são colmos novos que substituíram colmos fraturados que comprometiam a estabilidade estrutural do sistema. 
A contagem dos colmos é:

- 77 colmos velhos inteiros

- 96 colmos velhos que apresentam fendilhamento na superfície

- 27 colmos novos inteiros

- 16 colmos novos que apresentam fendilhamento

\section{FIGURA 7}

Modelo tridimensional da cobertura.

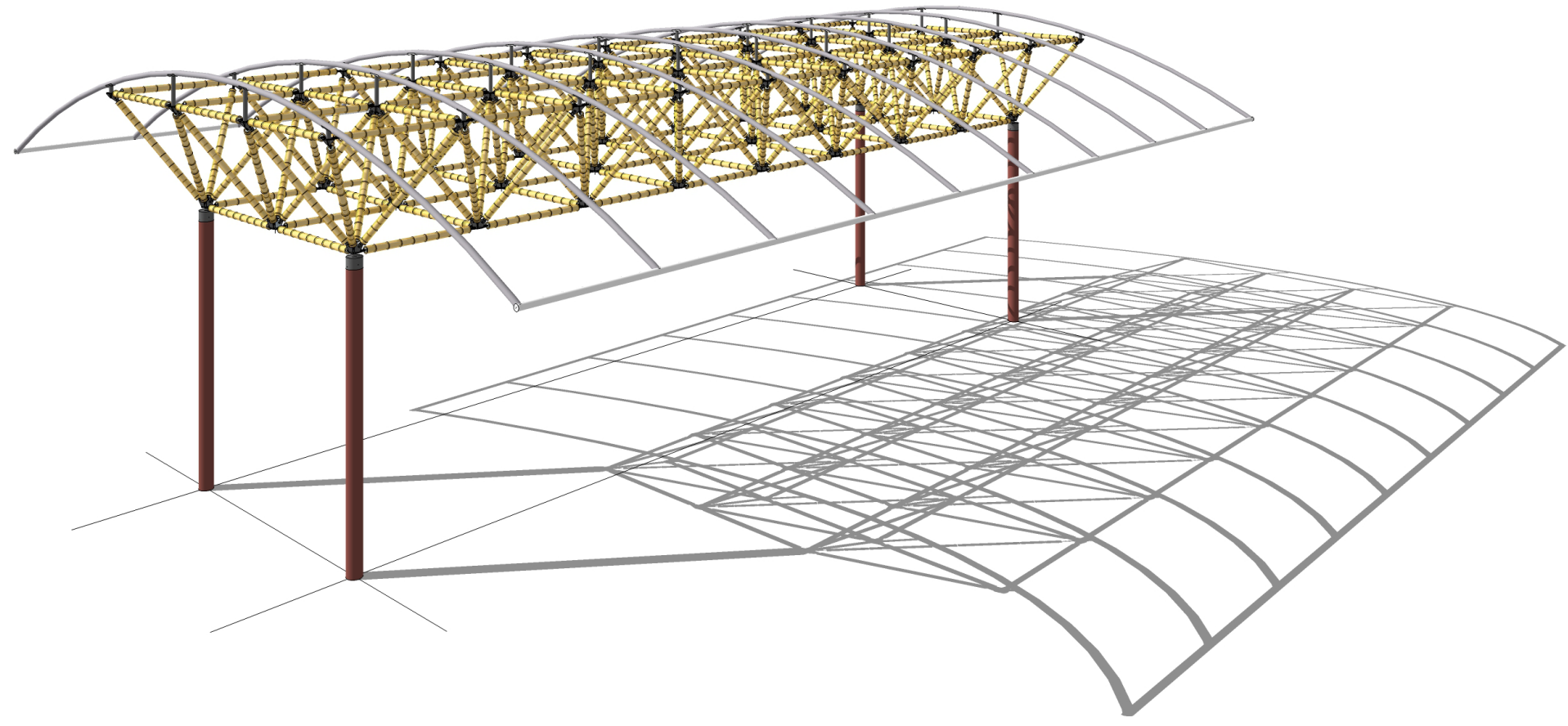



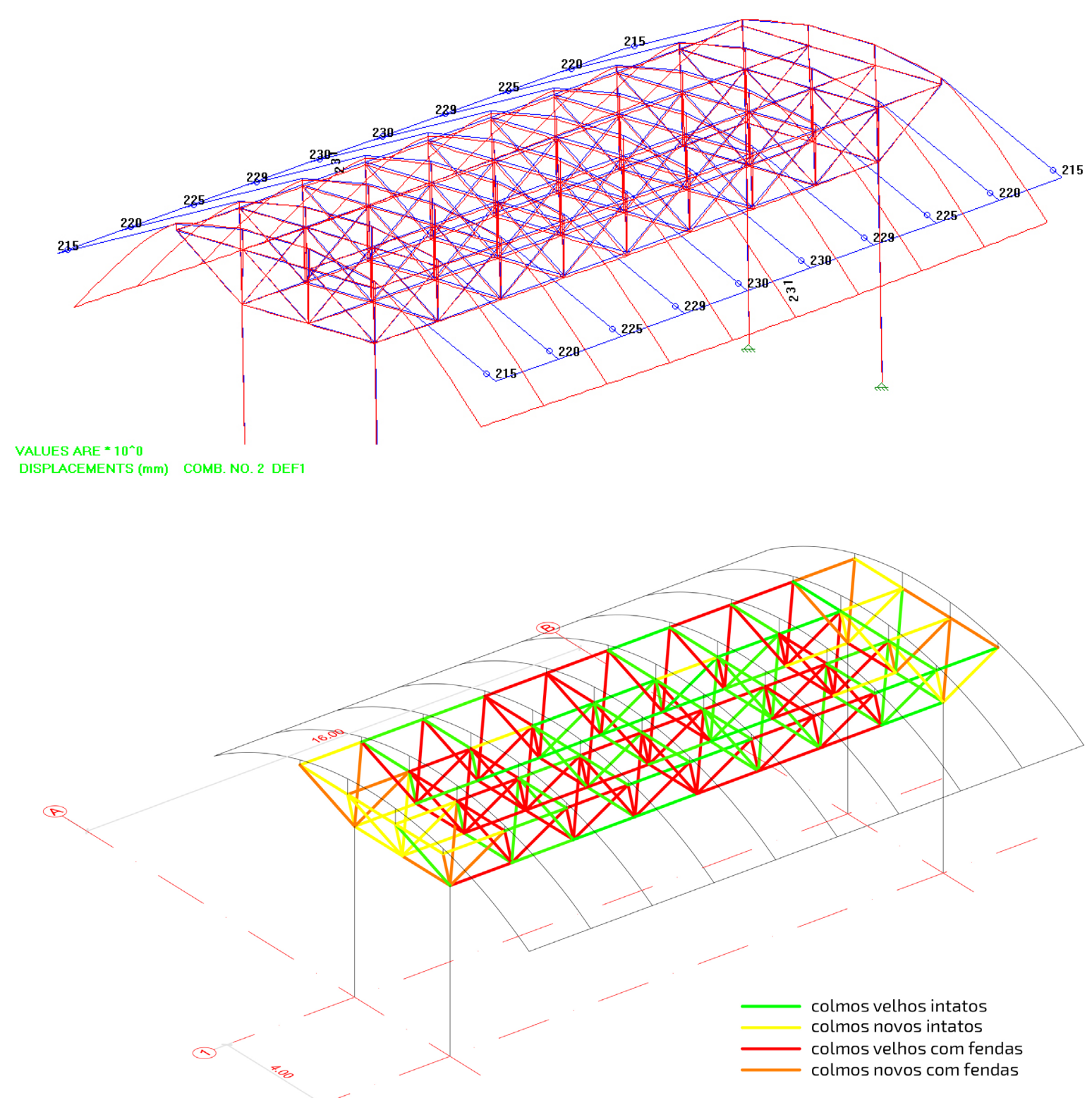

FIGURA 8

Deformações da estrutura.

\section{FIGURA 9}

Esquema

tridimensional do estado dos colmos. 


\section{2 .3}

Análise das conexões

Foram executadas 67 conexões metálicas, todas multidirecionais feitas de platibandas metálicas soldadas que se unem às barras das extremidades dos colmos por meio de parafusos e porcas. Estas conexões estão classificadas dentro do grupo 2, segundo a discriminação de Janssen (2000), e são conexões do interior para um elemento paralelo, apresentando nível 3 de complexidade tecnológica.

Lista das conexões:

- 4 Conexões de esquina de apoio nas colunas de eucalipto (Figura 10 )

- 7 Conexões de centrais da capa inferior (Figura 11)

- 14 Conexões laterais da capa inferior compridas

- 2 Conexões laterais da capa inferior curtas (Figura 12)

- 4 Conexões de esquina da capa superior (Figura 13)

- 16 Conexões laterais da capa superior compridas

- 4 Conexões laterais da capa superior curtas (Figura 14)

- 8 Conexões centrais da capa superior (Figura 15) 

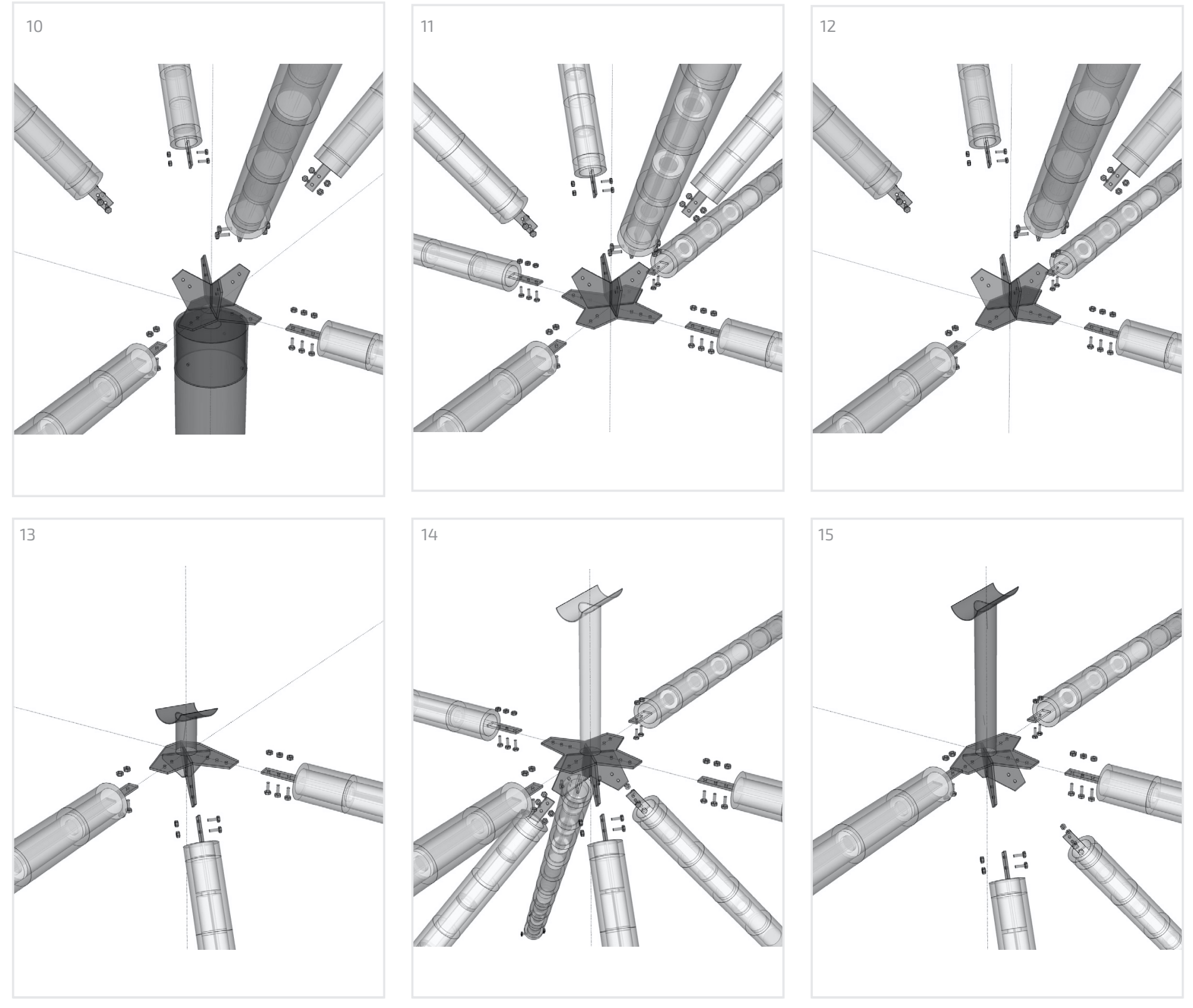
5.2 .4

Levantamento patológico

FIGURA 16

Foto: Joan Font.

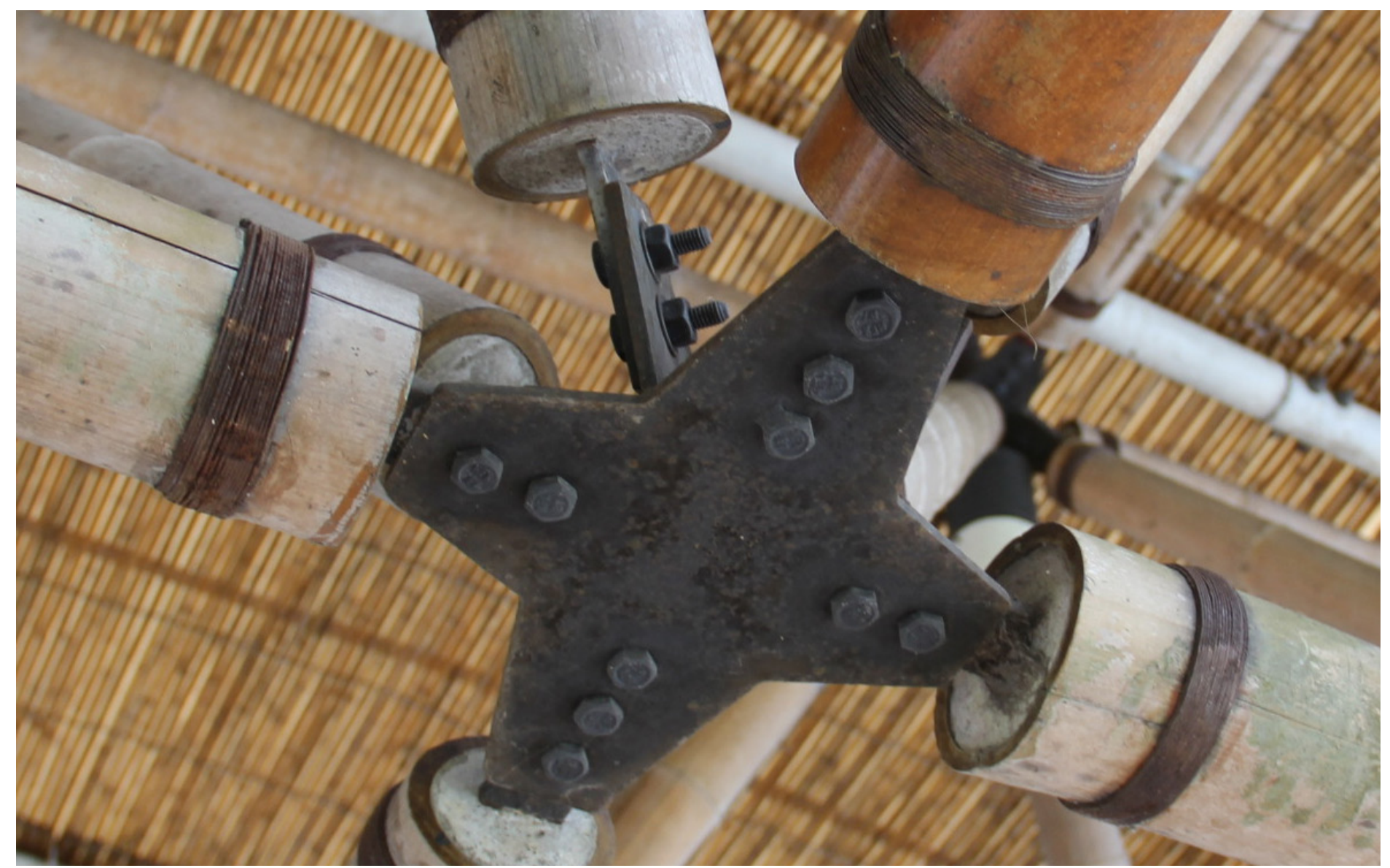




\section{Descrição por inspecão visual}

Oxidação superficial do aço das conexões. (Figura 16)

\section{Causa provável}

Em manutenção não foi aplicado, ou foi aplicado de forma incorreta, o tratamento superficial.

\section{Mecanismo de ocorrência}

A pintura superficial antioxidante aplicada aos elementos metálicos deteriorou-se permitindo que a água atmosférica entrasse em contato com o ferro das conexões criando a oxidação do mesmo. A substância que fica na superfície não altera as propriedades mecânicas do elemento, mas muda sua aparência.

\section{A patologia pode influir no(s)} seguinte(s) fator(es)

- Conforto visual.
Para a correção desta manifestação patológica deve-se

- Limar a superfície para eliminar o óxido de ferro e os restos de pintura deteriorada para garantir a aderência do novo tratamento

- Aplicar o novo tratamento.

Para a prevenção de novas patologias semelhantes deve-se

- Manutenção: deve haver reaplicação do tratamento com a periodicidade recomendada pelo fornecedor. 
FIGURA 17

Foto: Joan Font.

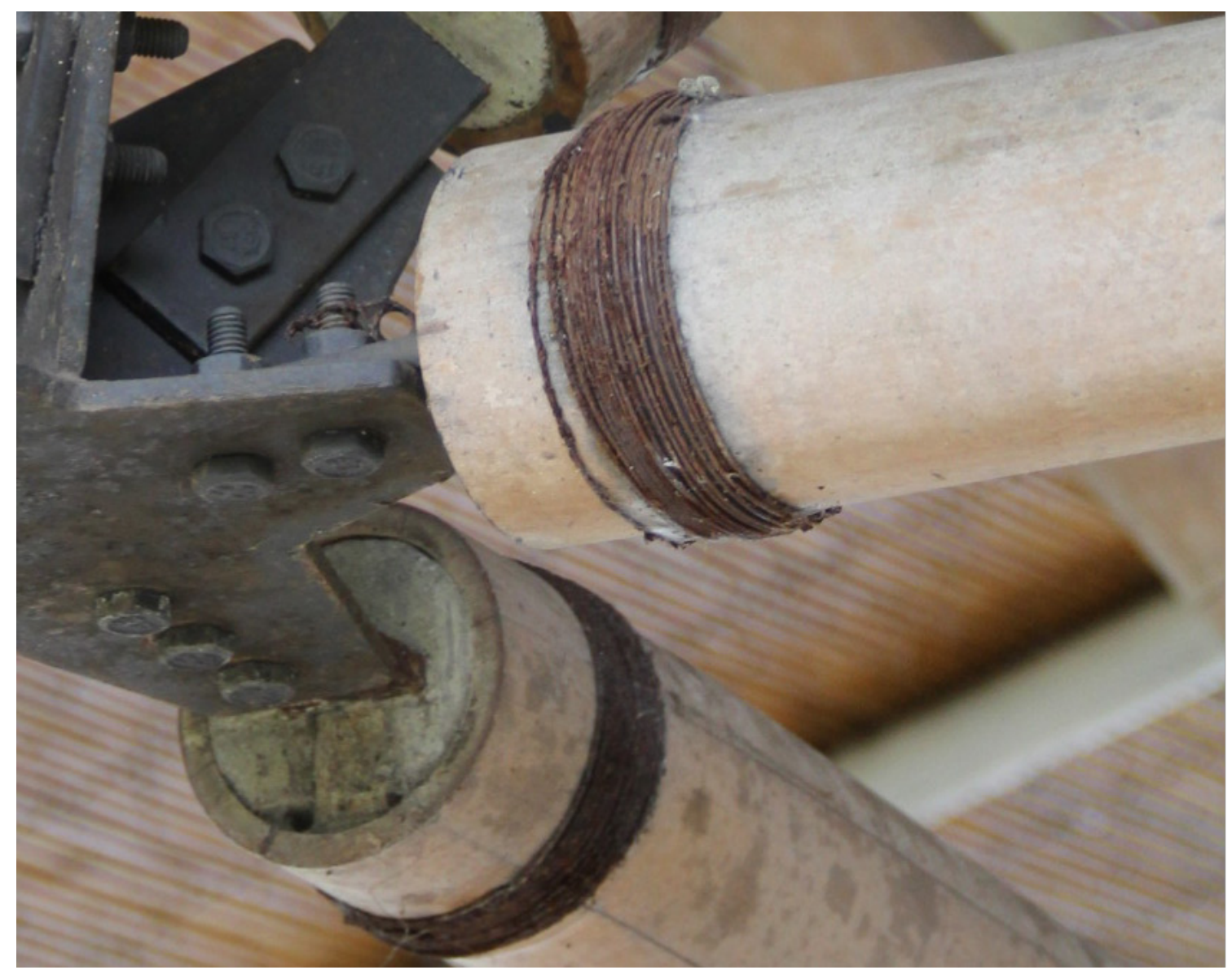




\section{Descrição por inspeção visual}

Oxidação superficial do arame recozido dos extremos dos bambus. (Figura 17)

\section{Causa provável}

Escolha de um material vulnerável a condições atmosféricas externas.

Não especificação de uma proteção mecânica. (Projeto)

\section{Mecanismo de ocorrência}

As braçadeiras metálicas dos extremos dos colmos de bambu que ajudam na rigidez evitando o fendilhamento do colmo por compressão radial, ao serem de ferro e não terem proteção superficial, estão expostas a condições ambientais semi-externas, e podem sofrer um processo de oxidação pelo contato com a água atmosférica, mudando sua aparência, textura e coloração

\section{A patologia pode influir no(s)} seguinte(s) fator(es)

- Conforto visual.

\section{Para a correção desta manifesta-} ção patológica deve-se

- Limar a superfície para eliminar o óxido de ferro e os restos de pintura deteriorada para garantir a aderência do novo tratamento

- Aplicar o novo tratamento.

- Remover e trocar o arame por outra braçadeira ou arame que garanta a estabilidade química.

\section{Para a prevenção de novas pato-}

logias semelhantes deve-se

- Manutenção: deve haver reaplicação do tratamento com a periodicidade recomendada pelo fornecedor. 
FIGURA 18

Foto: Joan Font.

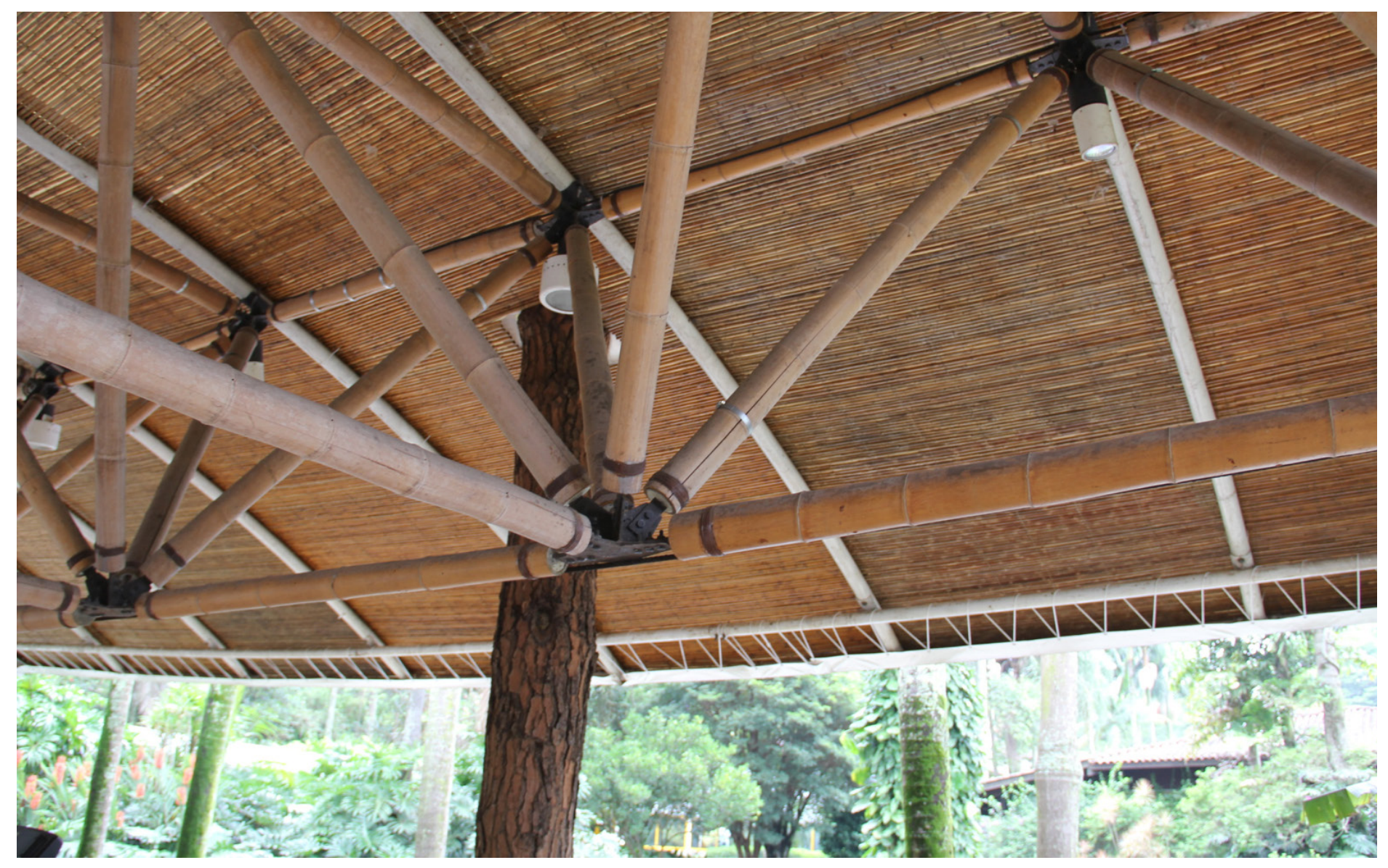




\section{Fendilhamento no extremo do colmo diagonal}

\section{Descrição por inspeção visual}

Rachadura no colmo diagonal, na extremidade inferior com a abertura maior na seção cortada. (Figura 18)

\section{Causa provável}

Transmissão de momentos fletores da conexão ao colmo de bambu. $\mathrm{Na}$ fase da concepção da conexão não foram previstas possíveis tensões residuais. (Projeto-cálculo)

\section{Mecanismo de ocorrência}

As conexões projetadas e produzidas exclusivamente para este projeto, teoricamente não deveriam transmitir momento fletor, mas na prática não existe conexão com articulação pura sem momento fletor. A barra diagonal de bambu além de ser comprimida é também deformada por um momento fletor. Esta deformação não acontece no concreto presente nas cavidades dos bambus. A flexibilidade e possibilidade de deformação do bambu embate-se com a rigidez do concreto interno provocando tensões de tração transversal às fibras, iniciando a fratura da parede do colmo na extremidade seccionada do bambu e se abrindo em direção ao outro extremo do colmo pela fibra neutra. $\mathrm{O}$ colmo preenchido de concreto em $60 \mathrm{~cm}$ de profundidade resulta em comportamentos muito diferentes da barra nos extremos e na região central.

\section{A patologia pode influir no(s) seguinte(s) fator(es)}

- Segurança estrutural;

- Durabilidade;

- Estanqueidade.

\section{Para a correção desta manifesta-} ção patológica deve-se

- Colocar braçadeiras metálicas que comprimam radialmente o bambu evitando o crescimento da fenda e evitando o colapso da peça.

- Trocar a barra inteira.
Para a prevenção de patologias semelhantes deve-se

- Projetar vínculos das conexões menos rígidos que consigam absorver os momentos fletores;

- Preencher por completo a barra de bambu com concreto para que a cavidade interior seja inteira rígida, e que o comportamento não varie dependendo da região da barra. 
FIGURA 19

Foto: Joan Font.

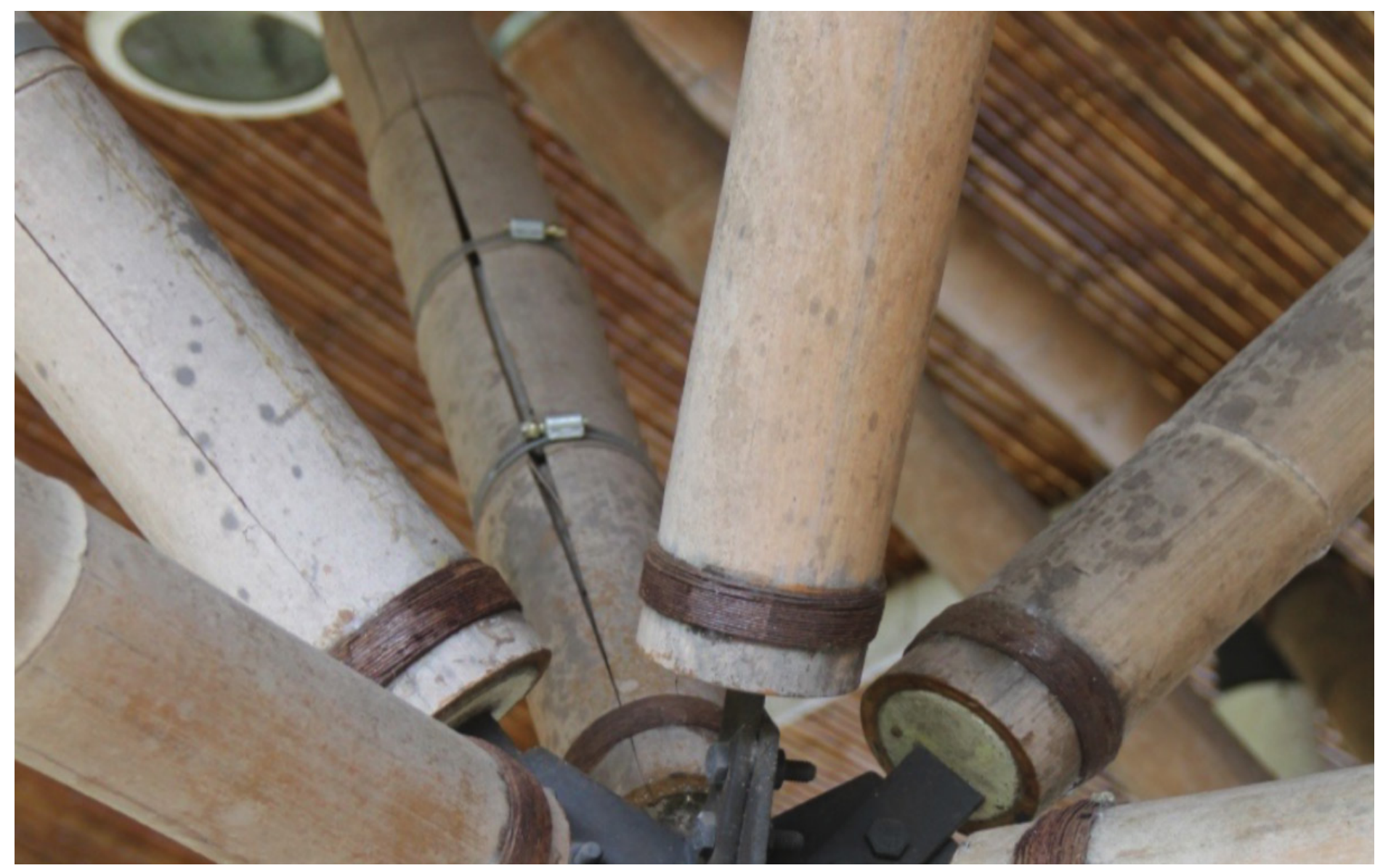




\section{Descrição por inspeção visual}

Fendilhamento axial do colmo diagonal com abertura maior central. (Figura 19)

\section{Causa provável}

Transmissão de momentos fletores da conexão ao colmo de bambu. $\mathrm{Na}$ fase da concepção da conexão não se previu possíveis tensões residuais. (Projeto-cálculo).

\section{Mecanismo de ocorrência}

As conexões projetadas e produzidas exclusivamente para este projeto teoricamente não deveriam transmitir momento fletor, mas na prática não existe conexão com articulação pura sem momento fletor. A barra diagonal de bambu além de comprimida é também deformada por um momento fletor. Esta deformação não acontece no concreto presente nas cavidades dos bambus. A região central do colmo não está preenchida, portanto, deforma mais, em con- traposição as extremos que são mais rígidos, e que não deformam. Esta tensão diferencial flexiona o bambu criando tensões de compressão nas camadas externas do colmo, na fibra superior, transformando-se em microflambagem e trações tangenciais que fraturam o bambu pela mesma fibra superior.

A fratura começa no centro do bambu e aumenta em direção aos extremos. A fratura não colapsou o bambu por causa da braçadeira do extremo do colmo.

\section{A patologia pode influir no(s) seguinte(s) fator(es)}

- Segurança estrutural;

- Durabilidade;

- Estanqueidade.

\section{Para a correção desta manifesta-} ção patológica deve-se

- Colocar braçadeiras metálicas que comprimam radialmente o bambu evitando o crescimento da fenda e evitando o colapso da peça.

- Trocar a barra inteira.

Para a prevenção de novas patologias semelhantes deve-se

- Projetar vínculos das conexões menos rígidos que consigam absorver os momentos fletores;

- Preencher por completo a barra de bambu com concreto para que seja o corpo interior inteiro rígido, e que o comportamento não varie dependendo da região da barra. 
FIGURA 20

Foto: Joan Font.

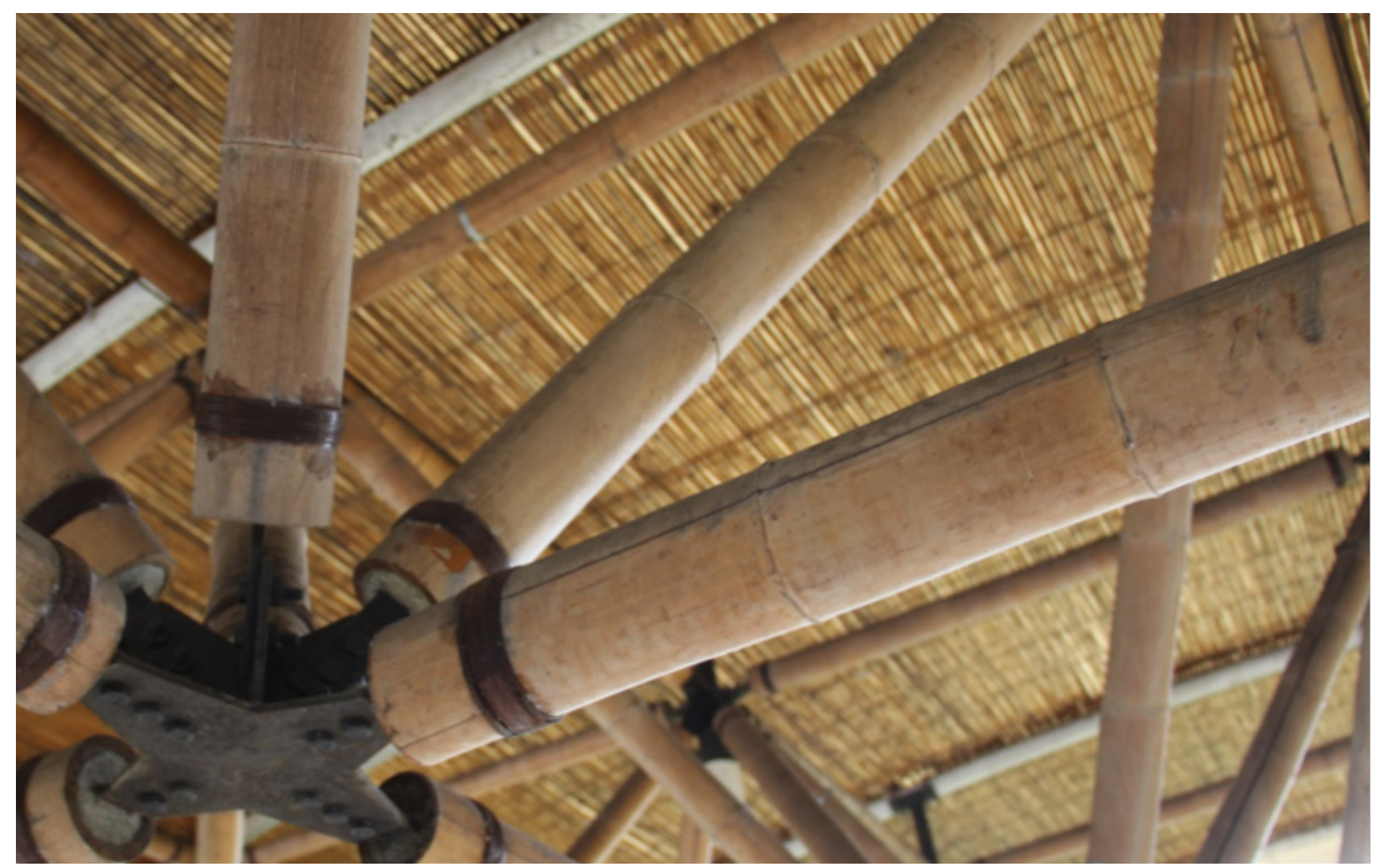




\section{Descrição por inspeção visual}

Fendilhamento axial do colmo horizontal com abertura maior central. (Figura 20)

\section{Causa provável}

Transmissão de momentos fletores da conexão ao colmo de bambu. $\mathrm{Na}$ fase da concepção da conexão não foram previstas possíveis tensões residuais. (Projeto-cálculo )

\section{Mecanismo de ocorrência}

A rigidez da conexão transmite momento fletor ao colmo horizontal de bambu. Este bambu sofre uma deformação que tem a maior flecha no centro do colmo, a deformação não acontece regularmente ao longo do colmo devido ao concreto presente apenas nas extremidades. A fratura acontece na fibra neutra e começa na região central do bambu e aumenta em direção aos extremos. A fratura não chega ao final devido à braçadeira do extremo do colmo que garante a estabilidade da barra.

\section{A patologia pode influir no(s)} seguinte(s) fator(es)

- Segurança estrutural;

- Durabilidade;

- Estanqueidade.

\section{Para a correção desta manifesta-} ção patológica deve-se

- Colocar braçadeiras metálicas que comprimam radialmente o bambu evitando o crescimento da fenda e evitando colapso da peça;

- Trocar a barra inteira.

\section{Para a prevenção de novas pato-}

logias semelhantes deve-se

- Projetar vínculos das conexões menos rígidos que consigam absorver os momentos fletores;

- Preencher por completo a barra de bambu com concreto para que seja o corpo interior inteiro rígido, e que o comportamento não varie dependendo da região da barra. 
FIGURA 21

Foto: Joan Font.

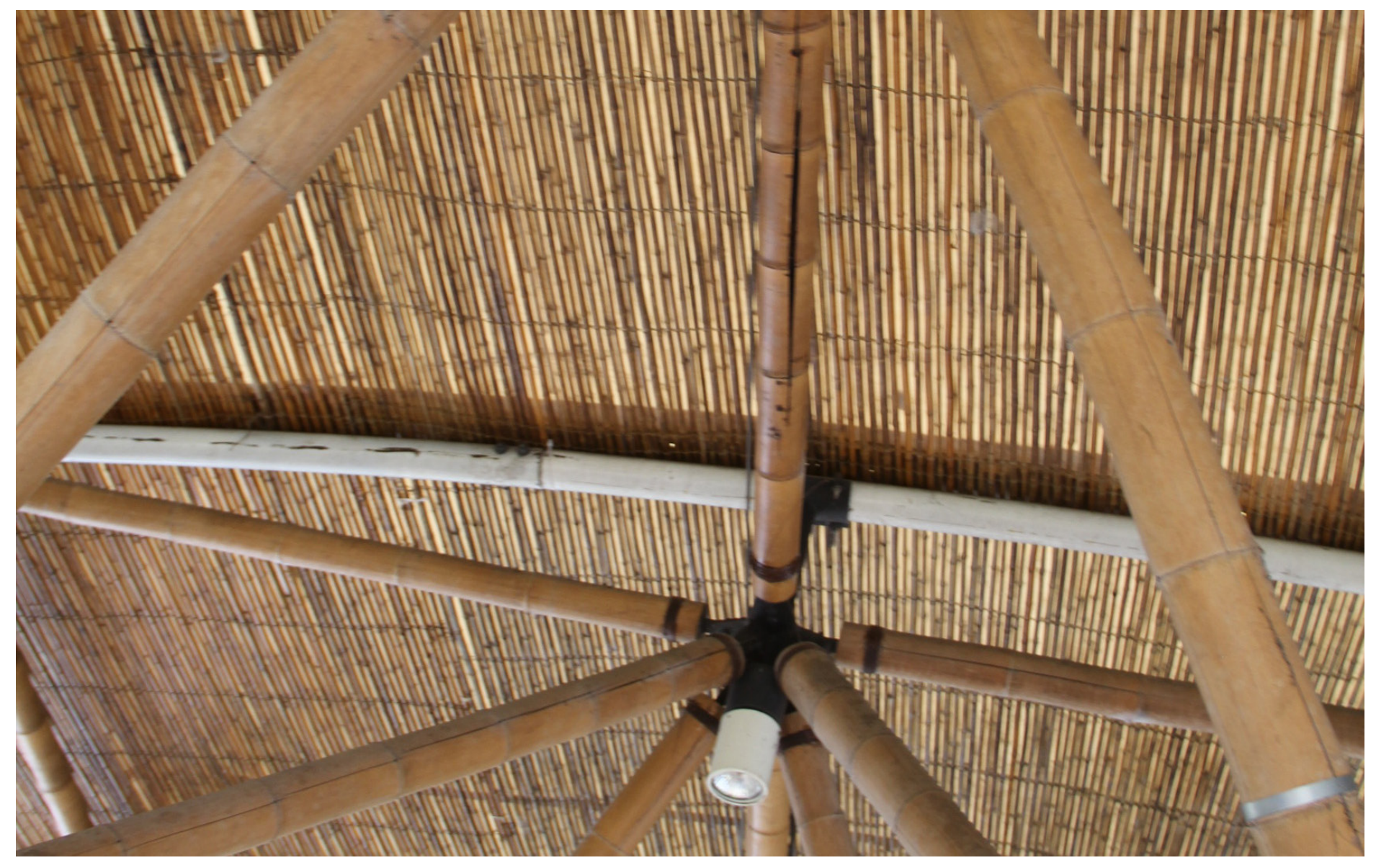


Fendilhamento no centro do colmo horizontal, por ataque biológico

\section{Descrição por inspeção visual}

Rachadura no colmo horizontal da malha superior na direção longitudinal da estrutura. A rachadura tem maior abertura no centro do colmo e se estende para os extremos. Existem furos circulares no córtex de $1 \mathrm{~cm}$ de diâmetro ,aproximadamente.

(Figura 21)

\section{Causa provável}

Perda de massa do bambu por ataque de inseto isóptero, na região mais solicitada do colmo. Transmissão de momentos fletores da conexão ao colmo de bambu. O tratamento preservativo escolhido não foi efetivo (Fornecedor-material)

\section{Mecanismo de ocorrência}

Os insetos consumiram parte da massa do colmo na região onde o momento fletor é maior. O colmo está situado na parte do conjunto estrutural com mais deformação por flexão.

As conexões transmitem momento fletor à barra. A rigidez dos extremos conseguida por meio do preenchimento de graute faz concentrar a deformação no centro do colmo, fendilhando inicialmente no furo inicial do inseto, e progredindo até os extremos da barra. A fenda apresenta abertura de maior dimensão na região do colmo com maiores tensões.

\section{A patologia pode influir no(s)} seguinte(s) fator(es)

- Segurança estrutural;

- Durabilidade;

- Estanqueidade.

Para a correção desta manifestação patológica deve-se

- Dedetizar o colmo, aplicar algum tratamento preservativo superficial. Selar a abertura, colocar braçadeiras metálicas que comprimam radialmente o bambu evitando o crescimento da fenda e evitando o colapso da peça;
- Trocar a barra inteira.

Para a prevenção de novas patologias semelhantes deve-se

- Selecionar outro tipo de tratamento para os colmos que evite o ataque de insetos, o cozimento para vapor mostrou-se de pouca eficiência. 
FIGURA 22

Foto: Joan Font.

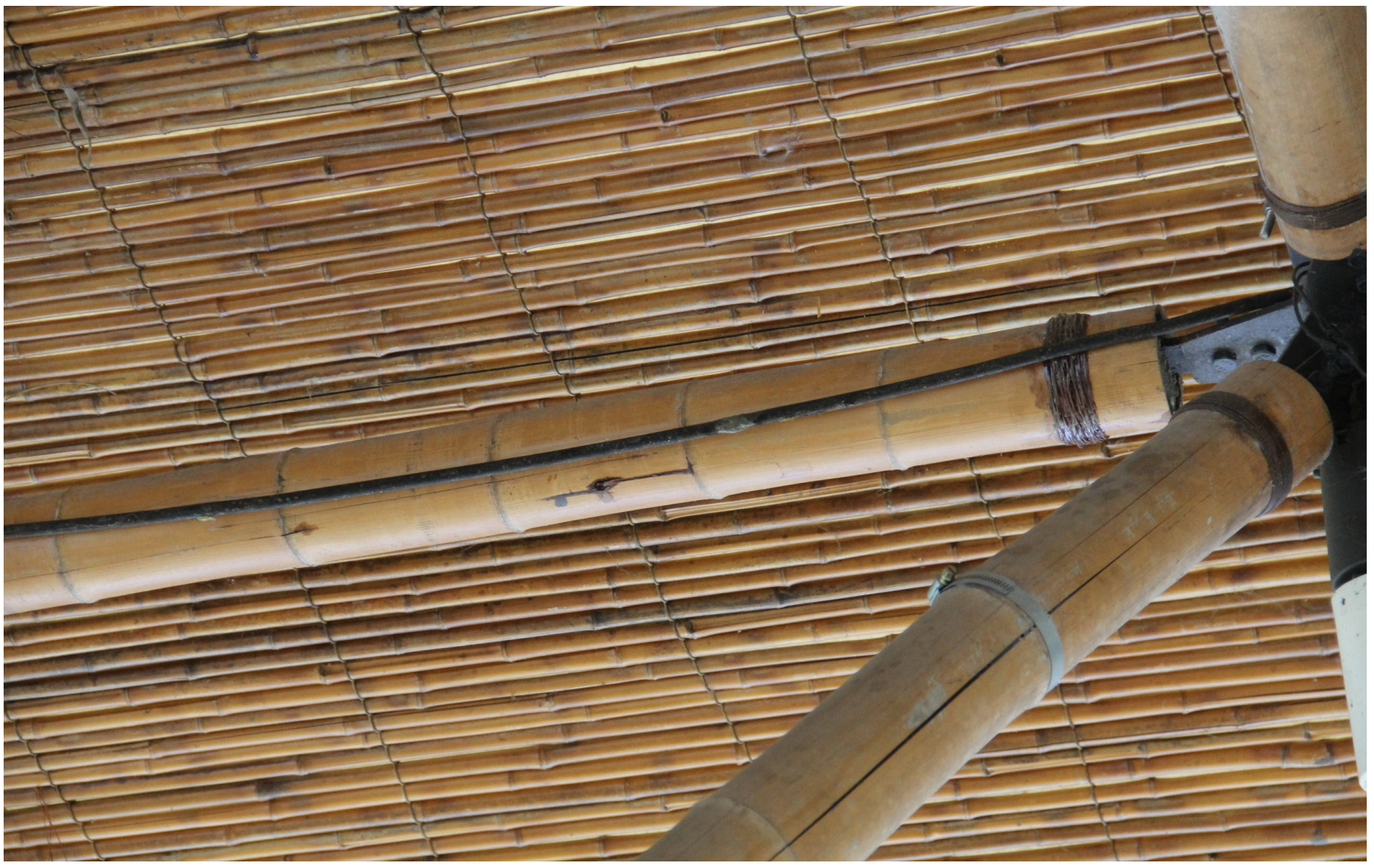




\section{Descrição por inspeção visual}

Furo preto no córtex no meio do internó com rachadura axial. (Figura 22)

\section{Causa provável}

Ataque ao colmo por parte de algum inseto isóptero. (Material-fornecedor)

\section{Mecanismo de ocorrência}

Os colmos antes de colocados em obra foram tratados por meio de cozimento a vapor, um tratamento pouco agressivo com o meio ambiente e com os agentes biológicos. $\mathrm{O}$ inseto perfurou o córtex e se instalou no interior da cavidade se alimentando do próprio colmo, a debilitação da barra, pela perda de massa resistente causou o fendilhamento do colmo desde o furo até ao nó mais próximo, onde existem fibras tangenciais que conseguiram conter a abertura.

\section{A patologia pode influir no(s)} seguinte(s) fator(es)

- Segurança estrutural;
- Durabilidade;

- Estanqueidade.

Para a correção desta manifestação patológica deve-se

- Dedetizar o colmo, selar a perfuração, e colocar braçadeiras metálicas para ajudar a conter o avanço da fenda;

- Trocar a barra inteira.

Para a prevenção de novas patologias semelhantes deve-se

- Utilizar outros tratamentos preservativos mais agressivos com os agentes biológicos e que garantam uma durabilidade maior. A arquiteta Leiko Motomura, em entrevista, considera o método da autoclave como o mais eficiente. 
FIGURA 23

Foto: Joan Font.

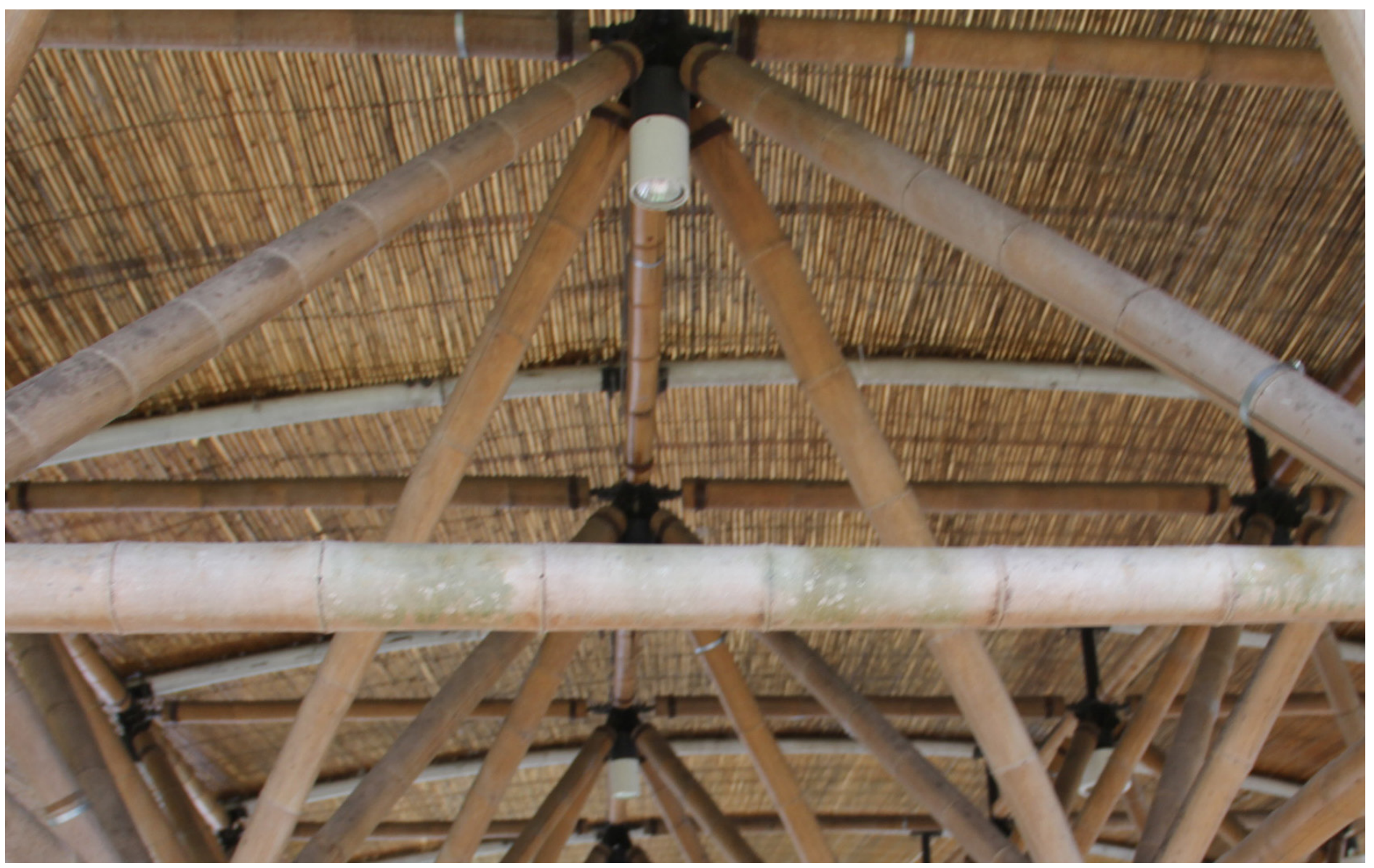




\section{Descrição por inspeção visual}

Coloração esverdeada e mudança de textura do colmo horizontal.(Figura 23)

\section{Causa provável}

Exposição constante à humidade sem renovação de tratamentos superficiais nos colmos (manutenção).

\section{Mecanismo de ocorrência}

Pela exposição constante a agentes atmosféricos o córtex do bambu se degradou e ganhou aderência. Fungos foram depositados na superfície, e pela ação da humidade se desenvolveram e cresceram mudando a coloração e textura do colmo.

A patologia pode influir no(s) seguinte(s) fator(es)

- Conforto visual.

Para a correção desta manifestação patológica deve-se

- Limar o colmo e aplicar verniz superficial.
Para a prevenção de novas patologias semelhantes deve-se

- Aplicar de tempos em tempos proteções mecânicas na superfície dos colmos para evitar a aparição de fungos. 
FIGURA 24

Foto: Joan Font.

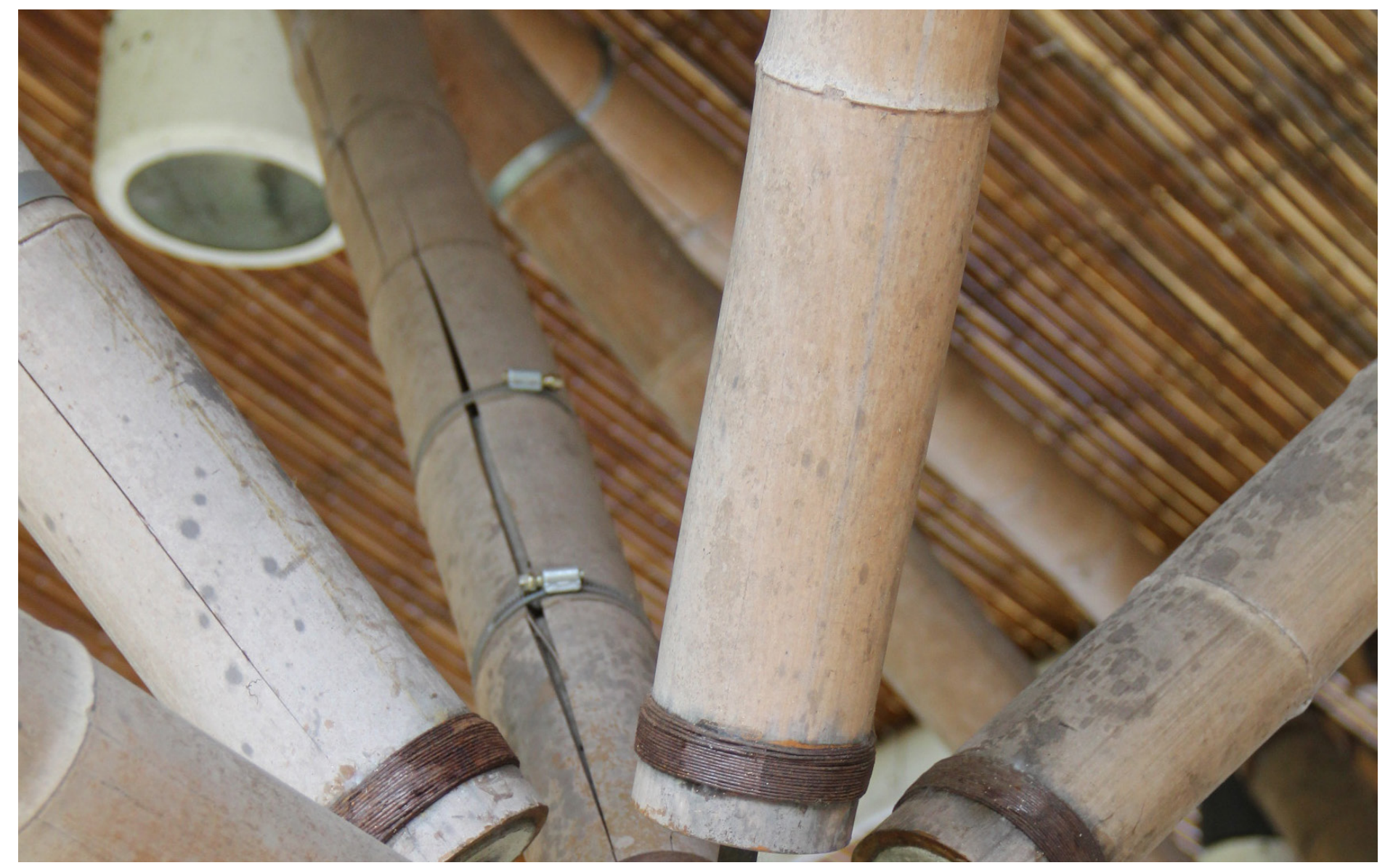




\section{Descrição por inspecão visual}

Manchas pretas e mudança de textura

do córtex superior do colmo diagonal. (Figura 24)

\section{Causa provável}

Exposição constante à umidade sem renovação de tratamentos superficiais nos colmos (manutenção).

\section{Mecanismo de ocorrência}

Pela exposição constante aos agentes atmosféricos o córtex do bambu se degradou e ganhou aderência. Fungos foram depositados na superfície, e pela ação da umidade se desenvolveram e cresceram mudando a coloração e textura do colmo.

\section{A patologia pode influir no(s)} seguinte(s) fator(es)

- Conforto visual;

- Durabilidade.
Para a correção desta manifestação patológica deve-se

- Lixar o colmo, aplicar verniz superficial.

\section{Para a prevenção de novas pato-}

\section{logias semelhantes deve-se}

- Aplicar regularmente proteções mecânicas na superfície dos colmos para evitar a aparição de fungos. 
- O bambu é uma escolha quase óbvia quando se propõe construir uma estrutura de vetor-ativo, como uma treliça espacial, quando se tem a intenção de usar materiais não convencionais que sejam mais sustentáveis.

- O bambu tem uma excelente resposta na resistência em esforços de tração e compressão, e também à flexão. Mas a flexão tem que ser dentro de um sistema isostático como quando é encontrado na natureza. Naturalmente o colmo de bambu é um sistema isostático pois a raiz é um engaste com restrições nos 6 movimentos, e com uma das extremidades com 6 graus de liberdade.

- Não existem na prática vínculos totalmente articulados, todos os vínculos têm algum grau de rigidez, que pode transmitir momento fletor na barra.

- Quando as barras de bambu de um sistema tridimensional estão em condições isostáticas, e suportando esforços axiais ou momentos fletores, a estabilidade da barra é garantida. Quando o bambu tem no mínimo um grau aparecer fendas na superfície devido a pequenas tensões residuais no colmo que o fazem colapsar, como por exemplo a compressão em uma barra hiperestática pode criar tensões residuais de tração perpendicular às fibras por microflambagem das fibras.

- Observando o esquema tridimensional do estado dos colmos, pode se deduzir que os colmos perto dos apoios estão mais tensionados, pois eles carregam o peso dos colmos do centro do vão, e tem maior momento fletor. Quanto mais perto dos pilares mais solicitados estão os colmos.

- O fendilhamento acontece em duas situações na região central do colmo, sendo originado por momento fletor, ou no extremo do colmo originado por tração perpendicular às fibras.

- O sistema de fixação das barras metálicas das extremidades causou muitas patologias, pela diferença de rigidez entre o bambu e o concreto, pois cada material tinha respostas diferentes na flexão. A flexibilidade do bambu é incompatível com a do concreto se existe flexão e o colmo não é preenchido na totalidade das cavidades do bambu.

- Uma ação básica de projeto seria a escolha de fazer sistemas ultra rígidos que não permitissem a troca de peças, ou se utilizar sistemas ultra articulados com o menor grau de hiperestaticidade para evitar transmissão de momentos. 
5.3

Estudo de caso:

Centro Cultural Max Feffer

FIGURA 1

Centro Cultural Max

Feffer.

Foto: Joan Font.

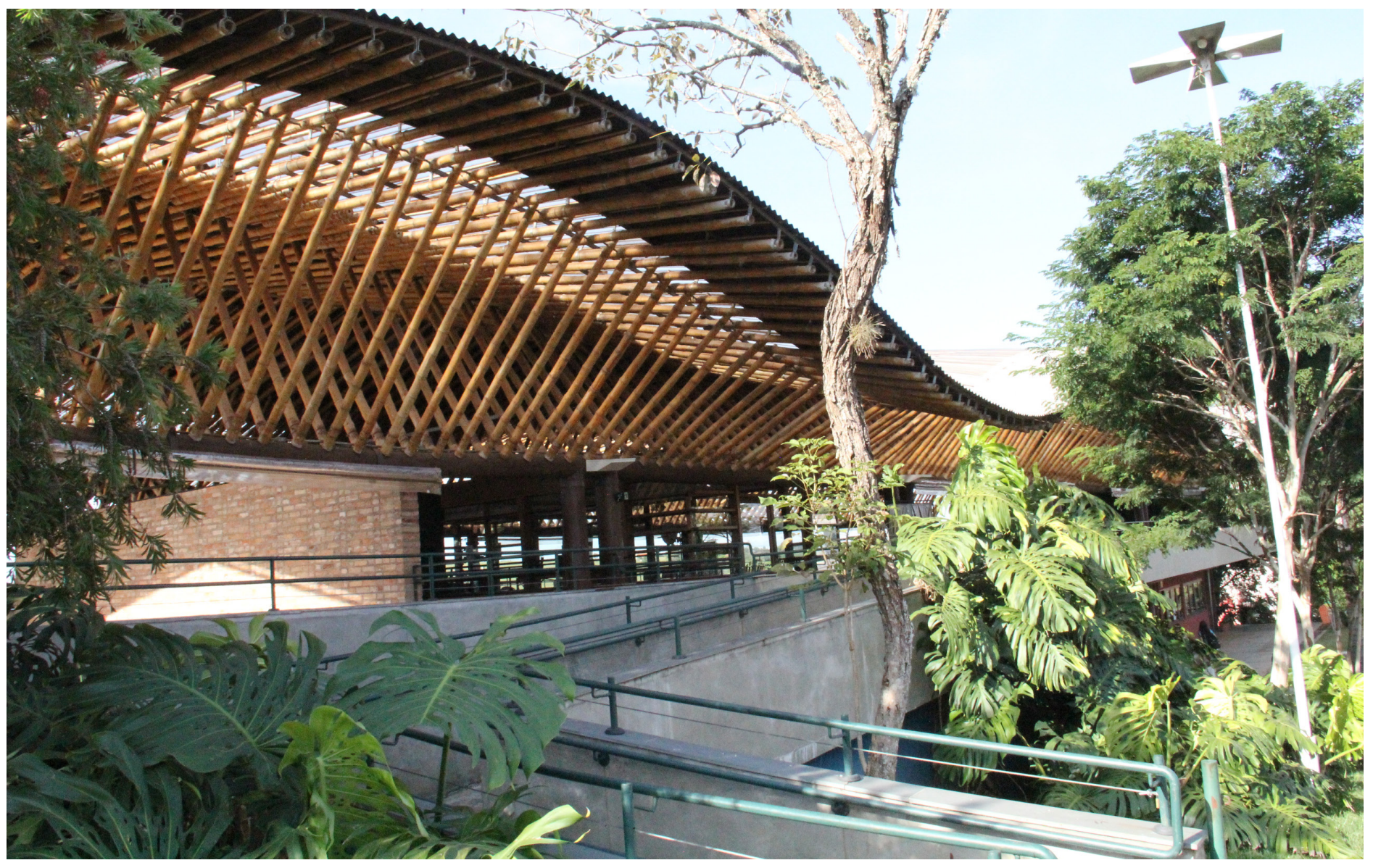


Localização: Estrada Boiadeira, Pardinho (SP)

Arquitetura: Amima Arquitetura (Leiko Hama Motomura)

Estrutura: Njl Engenharia e Projetos S/C (Natan Jacobsohn Levental)

Ano do projeto: 2008

Ano de conclusão da obra: 2008

Área do terreno: $7130 \mathrm{~m}^{2}$

Área construída: $1651 \mathrm{~m}^{2}$

\subsection{1}

0 projeto de arquitetura

O projeto (Figura 1) é um espaço institucional privado, com caráter educacional e cultural que abriga o Instituto Jatobás. A construção faz parte do programa "Projeto Pardinho", que tem como objetivo incentivar políticas de desenvolvimento sustentável no âmbito ecológico e sociocultural na cidade de Pardinho (SP).

A premissa principal do projeto era a concepção de um edifício sustentável num terreno onde havia a preexistência de sanitários públicos e um palco para eventos do município.

A ideia central de um ambiente sustentável se baseia na utilização de sistemas, materiais e recursos com o mínimo de impacto ambiental e alguns princípios claros:

1) Redução de recursos utilizados durante a construção e a utilização do espaço, tanto materiais como energéticos, implementando sistemas passivos para o conforto ambiental, assim como outros sistemas ativos para a redução de consumo de eletricidade e de água.

Foram utilizadas células fotoelétricas na iluminação externa, células fotovoltaicas na iluminação com LEDs, parede trombe para aquecimento de ambientes, metais hidrossanitários econômicos, ventilação natural, iluminação zenital.

2) Reúso de recursos. Reutilização de materiais provenientes de outras construções. (Tijolos de demolição, Caixilhos de madeira de demolição,
Reúso de água cinza para descargas sanitárias, Uso da água de descarte da zona de raízes para irrigação do jardim, corrimãos de ônibus desmanchados.

3) Reciclagem de recursos. Utilização de materiais de fontes e recicláveis. (Gradil com reúso de resíduo industrial, Bancos e bebedouros com reúso de resíduos, Tijolos de solo-cimento, Telhas de fibras vegetais.)

Graças às boas práticas arquitetônicas, o edifício teve uma redução de 25,6\% no consumo energético em contraste com construções convencionais. Priorizou-se a ventilação e a iluminação naturais, o reaproveitamento das águas pluviais e o uso racional de materiais de baixo impacto ecológico. Todas essas ações combinadas facilitaram a obtenção da certificação Leed Gold.

O edifício ocupa $15 \%$ do terreno cedido pela prefeitura, e o programa do edifício se desenvolve em dois andares. No andar térreo, há salas de 


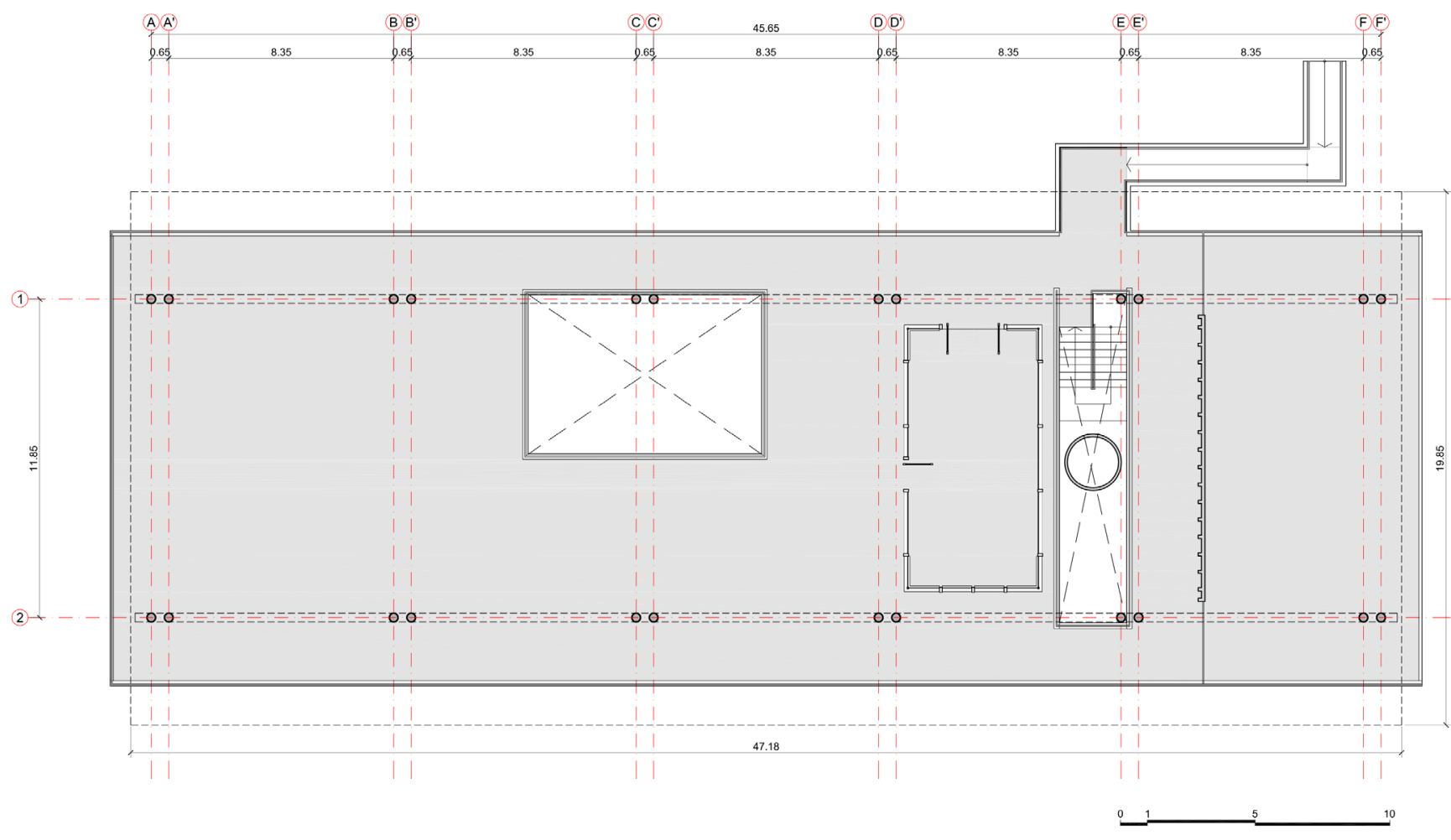

FIGURA 2

Planta da praça. 


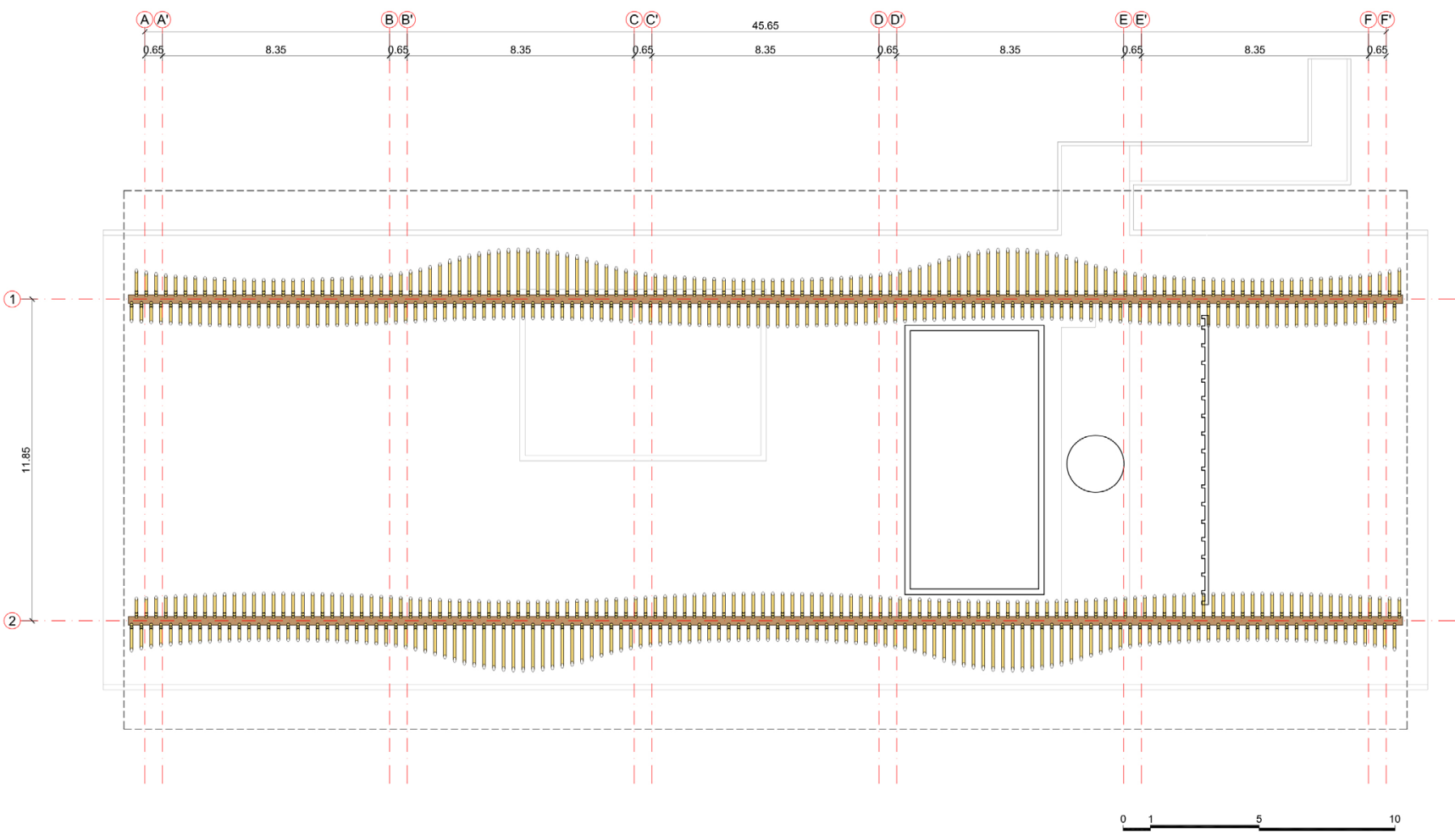

FIGURA 3

Planta de secção. 


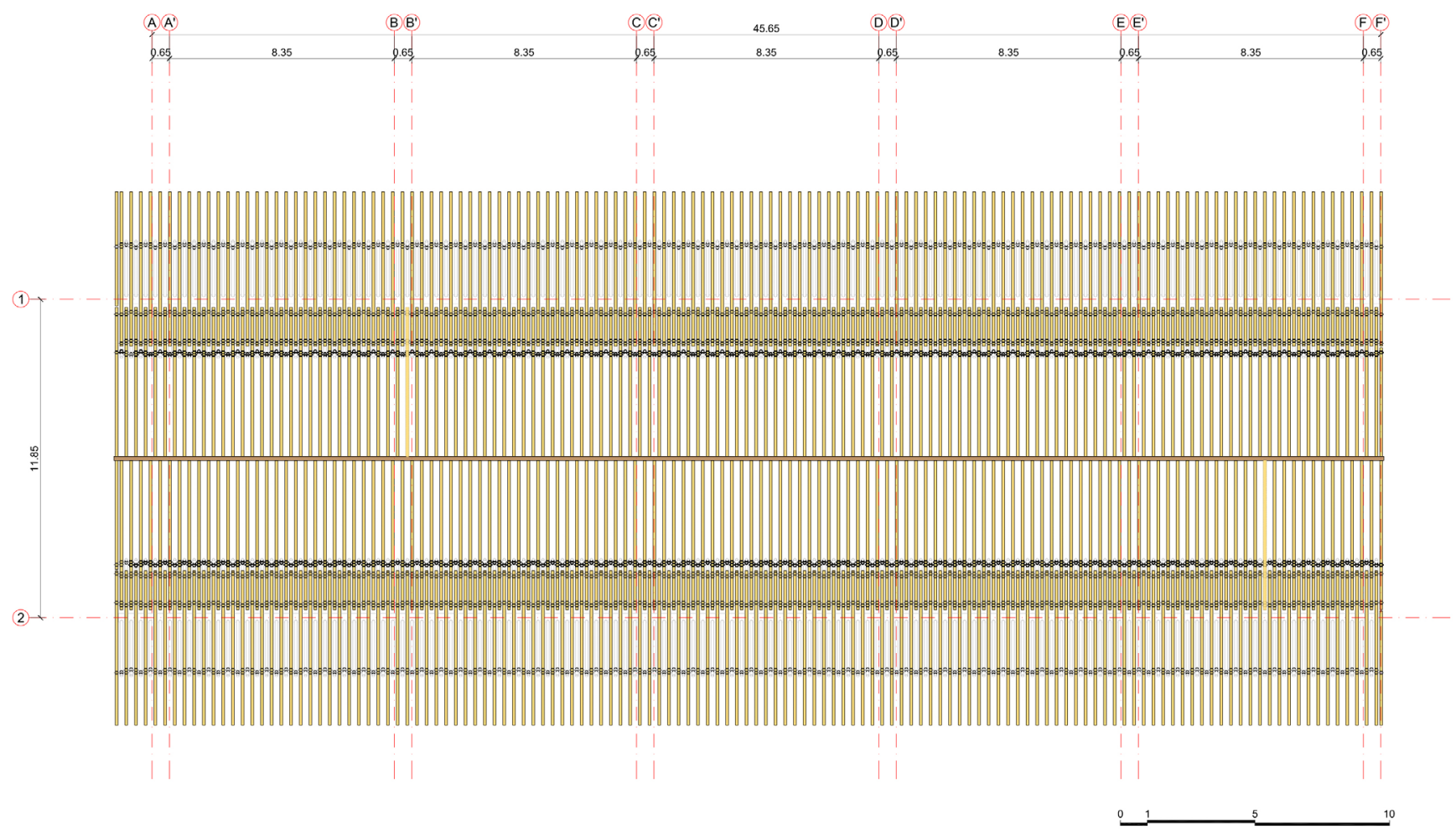

FIGURA 4

Planta da cobertura sem telhas. 


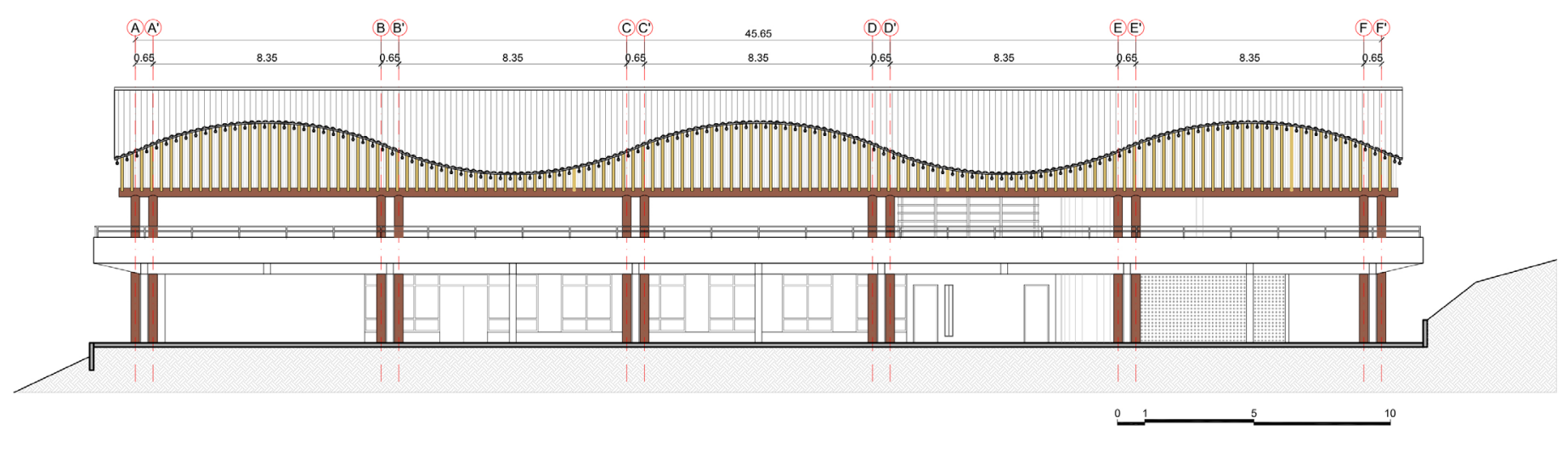




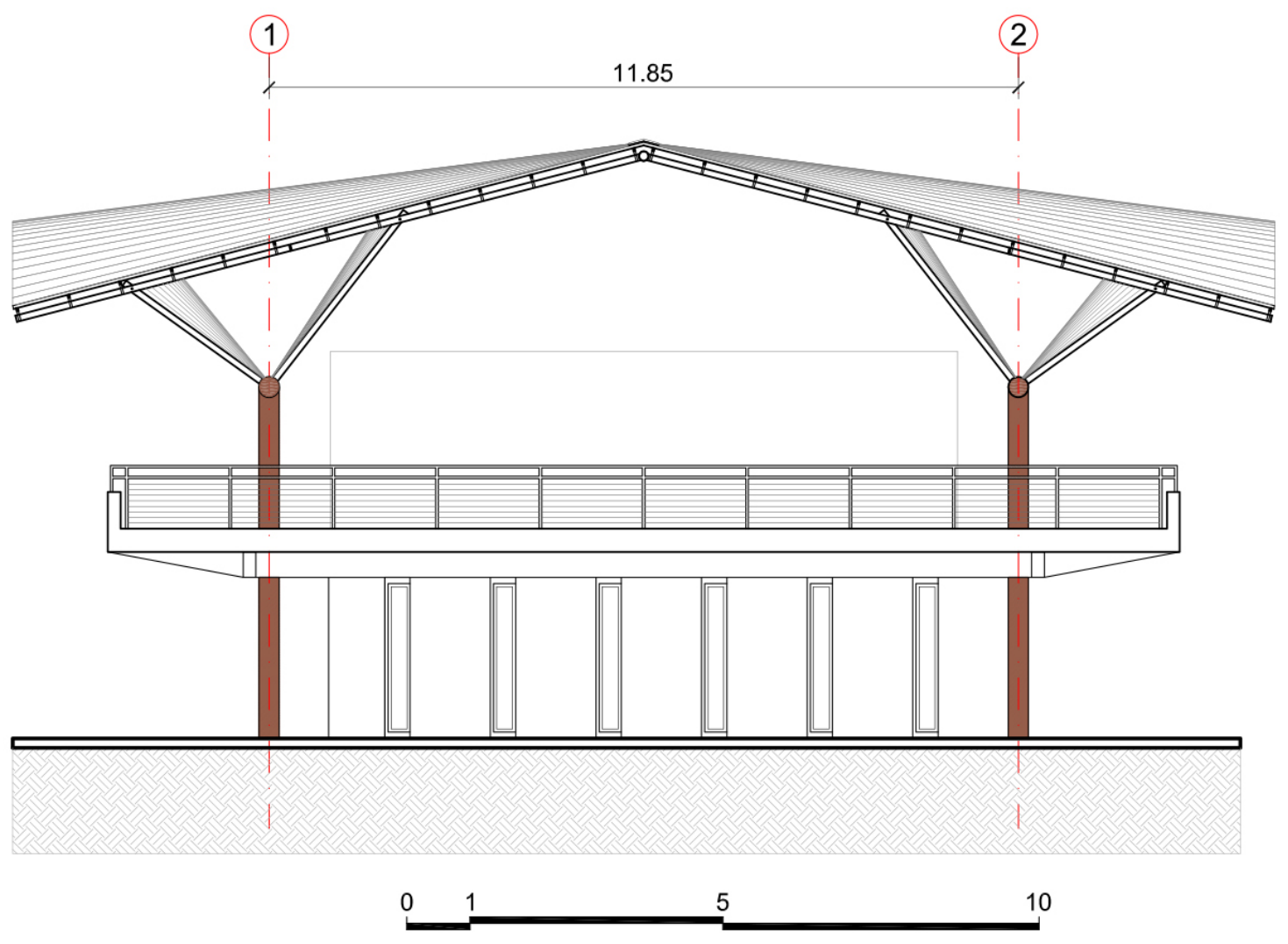




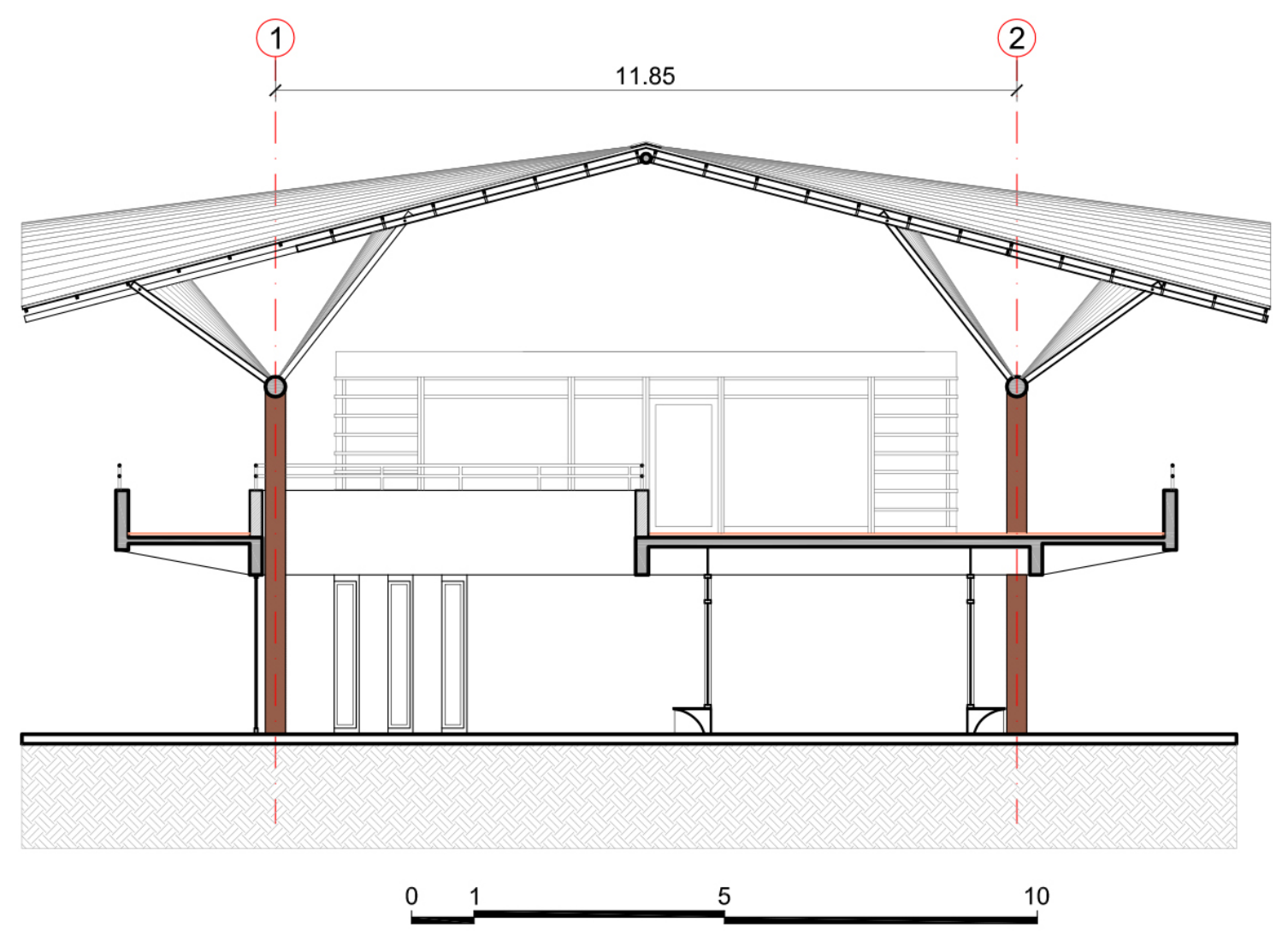

FIGURA 7

Corte transversal. 
leitura, área multiuso, sala de reuniões, biblioteca, escritório, depósito e sanitários. No andar superior (figura 2), um ambiente polivalente que seria uma praça semipública coberta, uma sala de exposições fechada e um palco que se abre ao terreno pelo Leste.

A grande peculiaridade do projeto é, sem dúvida, a grande cobertura sinuosa (figura 4) feita com colmos de bambu, que dá ao projeto leveza e uma personalidade muito inovadora.

\subsection{2}

A cobertura com estrutura de bambu

De acordo com a classificação de Engel (2001), a estrutura do Centro Cultural Max Feffer é um híbrido entre o sistema de vetor-ativo e o sistema de superfície-ativa. (Figura 7)

A cobertura está formada por duas águas, e a estrutura é composta por 1.048 colmos de bambu da espécie Guadua chacoensis de $10 \mathrm{~cm}$ de diâmetro, em média, tratados pelo sistema de imersão em uma solução de pentaborato de sódio.

Os bambus estão apoiados sobre duas vigas cilíndricas de madeira de eucalipto de, em média, $30 \mathrm{~cm}$ de diâmetro que, por sua vez, se apoiam em doze colunas com o mesmo diâ- cumeeira é também de eucalipto, com $15 \mathrm{~cm}$ diâmetro.

Cada viga de madeira sustenta 260 colmos de bambu diagonais colocados em forma de $\mathrm{V}$, e que descarregam o peso de outros 264 colmos, que têm a função de pernas sustentando as telhas e transmitindo os esforços para os colmos em V.

Há dois tipos de telhas na cobertura, uma opaca de fibra vegetal, e a outra translúcida, que permite a iluminação da praça pública. As telhas estão apoiadas em longarinas sinuosas que acompanham a curvatura da cobertura e em bambus do tipo Phyllostachys sp, que ajudam na distribuição de esforços e que se apoiam sobre as longarinas.(Figura 8)

As longarinas estão apoiadas sobre braçadeiras metálicas que sustentam os bambus-perna. Essas braçadeiras também cumprem a função de compressão radial do colmo, absorvendo esforços de tração perpendicular às fibras decorrentes de momentos fletores e de esforços de cisalhamento, que podem provocar fendas nos colmos.

Existe um princípio estético que faz referência à plasticidade do espaço construído e que tem um impacto muito positivo na materialização do edifício e da sua qualidade arquitetônica, que é o formalismo sinuoso e elegante da estrutura, que o transforma em uma obra singular.

A necessidade de que a construção cumpra com os requisitos do usuário, para ter um ótimo desempenho durante a vida útil do projeto, levou aos projetistas Leiko Motomura e Natan Levental a adotarem dois princípios construtivos para que o desempenho estrutural e a durabilidade fossem otimizados. Esses princípios foram fruto de experiências prévias com o material e nortearam as soluções construtivas da estrutura de cobertura.

Para o requisito da durabilidade, era necessário primeiramente um controle de qualidade mínimo sobre o tratamento preservativo ao qual o bambu seria submetido. Mas o principal era ser muito ciente, desde a etapa de projeto, que a vida útil do colmo de bambu não é muito prolongada, e é consideravelmente mais curta que a vida útil de qualquer edifício produzido com materiais convencionais. Por isso, deve-se dar as condições para que o usuário troque e faça a reposição de colmos degradados sem utilizar grandes recursos e que a estabilidade da estrutura estivesse garantida durante a troca.

A durabilidade é afetada pela falta de manutenção, os colmos da estrutura têm que ser pintados em intervalos de tempo de três anos. 


\section{FIGURA 8}

Modelo

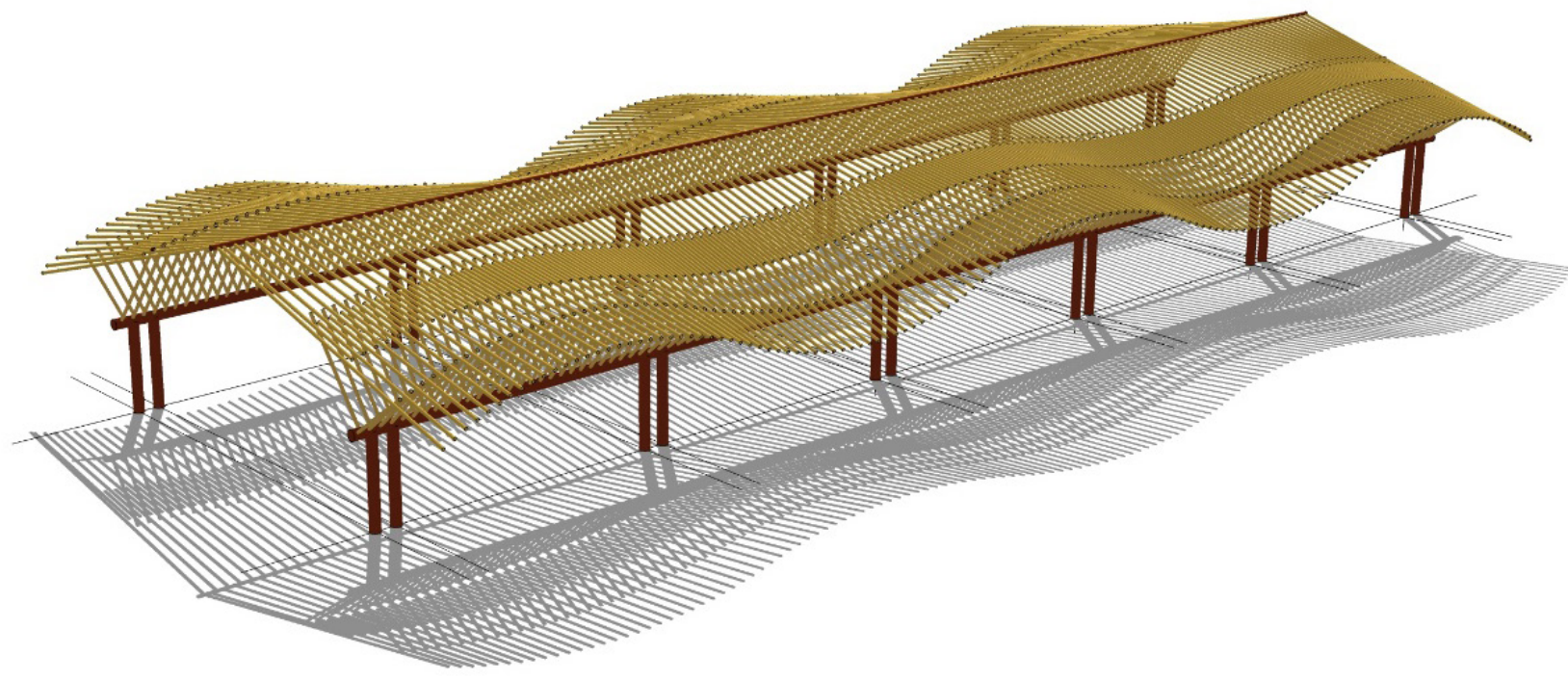

tridimensional da estrutura.

FIGURA 9

Detalhe da estrutura de cobertura.

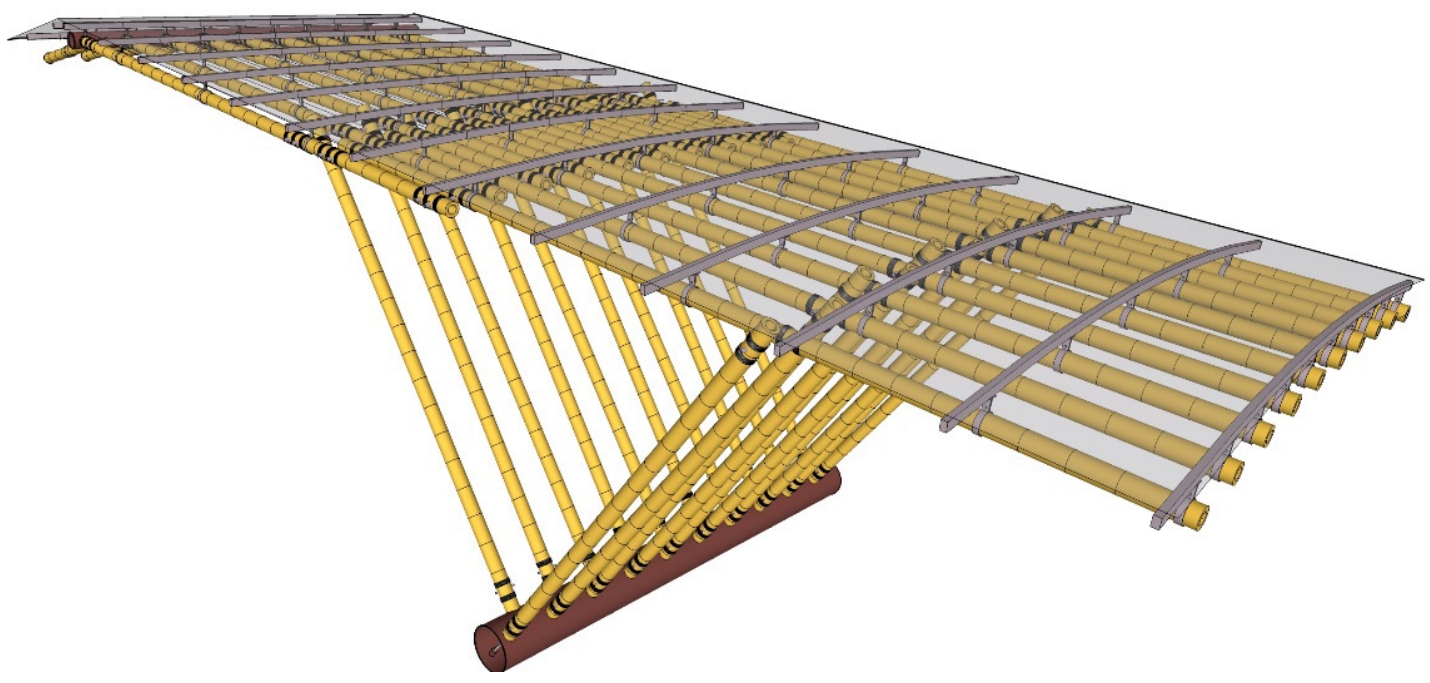


A última vez que foi pintada foi em 2013, segundo os registros dos funcionários do Instituto Jatobás. Anualmente é feita uma fumigação para controlar pragas de insetos que possam atacar os colmos.

Eis que surge o conceito de redundância estrutural. A estrutura foi superdimensionada para, caso seja feita uma troca, não sejam necessárias estruturas complementares para garantir a integridade do conjunto. Para isso, foram projetadas conexões metálicas ou de junta seca que não exigem operações destrutivas, sendo apenas realizada uma simples montagem e desmontagem dos elementos danificados.

Para o requisito da estabilidade estrutural, foi definido que as conexões não poderiam transmitir momentos fletores. Os colmos com função de perna trabalhariam à flexão e transmitiriam apenas aos colmos em "V" cargas axiais como compressão. As conexões entre colmos de bambu permitiriam sua rotação deles, mas não o deslocamento vertical nem horizontal. Nas conexões com os eucaliptos, as conexões também seriam articuladas - ou ao menos na teoria.

A estrutura então é formada por uma sequência de colmos intercalados fixados na cumeeira que se conectam a outros em agrupamentos de três, para aumentar a superfície da cobertura. Esses colmos que funcionam como pernas estão conectados a outros colmos diagonais que transmitem os esforços para as vigas de eucalipto.

\section{3 .3}

\section{Análise das conexões}

\section{Conexões 1 e 2}

As conexões 1 e 2 são compostas por três colmos e cada colmo está atravessado transversalmente pelo centro da seção do colmo por um tubo metálico. Por dentro desse tubo metálico passa uma barra metálica rosqueada que une os três colmos e é travada lateralmente por porcas.(Figura 9)

Acima e abaixo dos tubos metálicos são colocadas braçadeiras de fibras de propileno para comprimir radialmente o colmo e evitar possíveis fendilhamentos.

A solução permite o giro de todas as barras, para conseguir a sinuosidade da estrutura, mas também para evitar transmissão de momento fletor.

O cilindro metálico aumenta a superfície de contato com a parede do colmo e evita a tração perpendicular às fibras ou o cisalhamento interlaminar, que poderia provocar o fendilhamento dos colmos e seu colapso. (Figura 10)
Para a trocar as barras, só se torna necessário desenrosquear as porcas e retirar as barras que atravessam o colmo a ser substituído, garantindo a estabilidade estrutural do conjunto, já que todas as barras estão fixadas pelas barras que têm dos dois lados.

Perto dos cilindros são colocadas braçadeiras de polipropileno que comprimem radialmente o colmo evitando o fendilhamento nas regiões mais frágeis, neste caso é a superfície de contato entre o cilindro de aço e a parede do colmo. (Figura 11)

Segundo a classificação de Janssen (2000), a conexão seria do Grupo 4 - conexões de seção transversal para elemento perpendicular. Poderia se considerar uma modificação da conexão intitulada Herbert Shear Pin (JAYANETTI; FOLLETT, 1998). Desde o ponto de vista da complexidade tecnológica as ligações são de nível 3. 


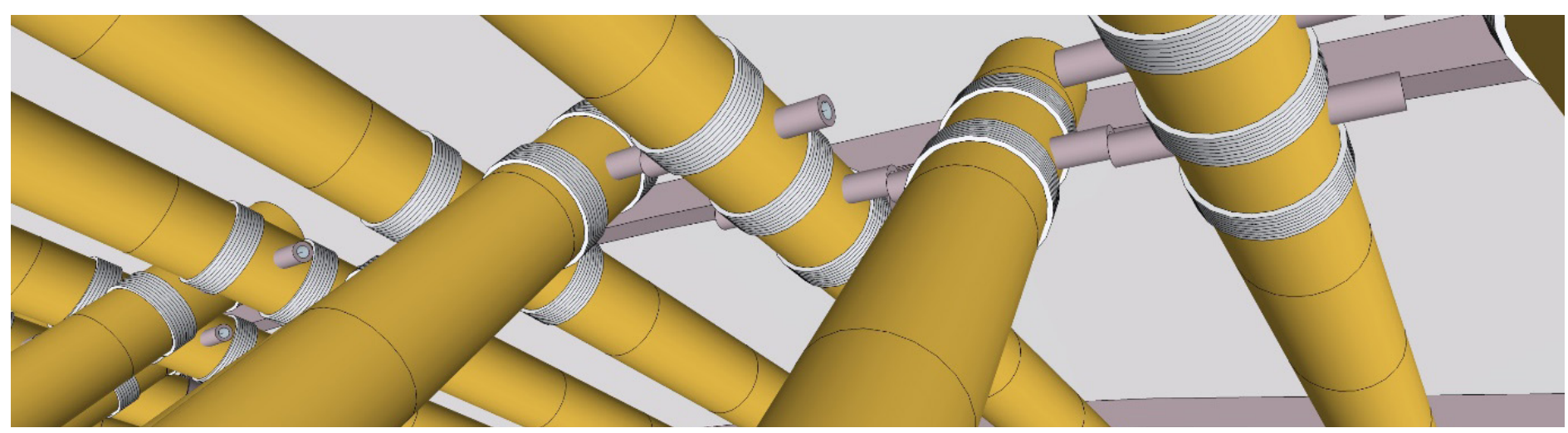

FIGURA 10

Conexão 1 entre

colmos diagonais e

as pernas.
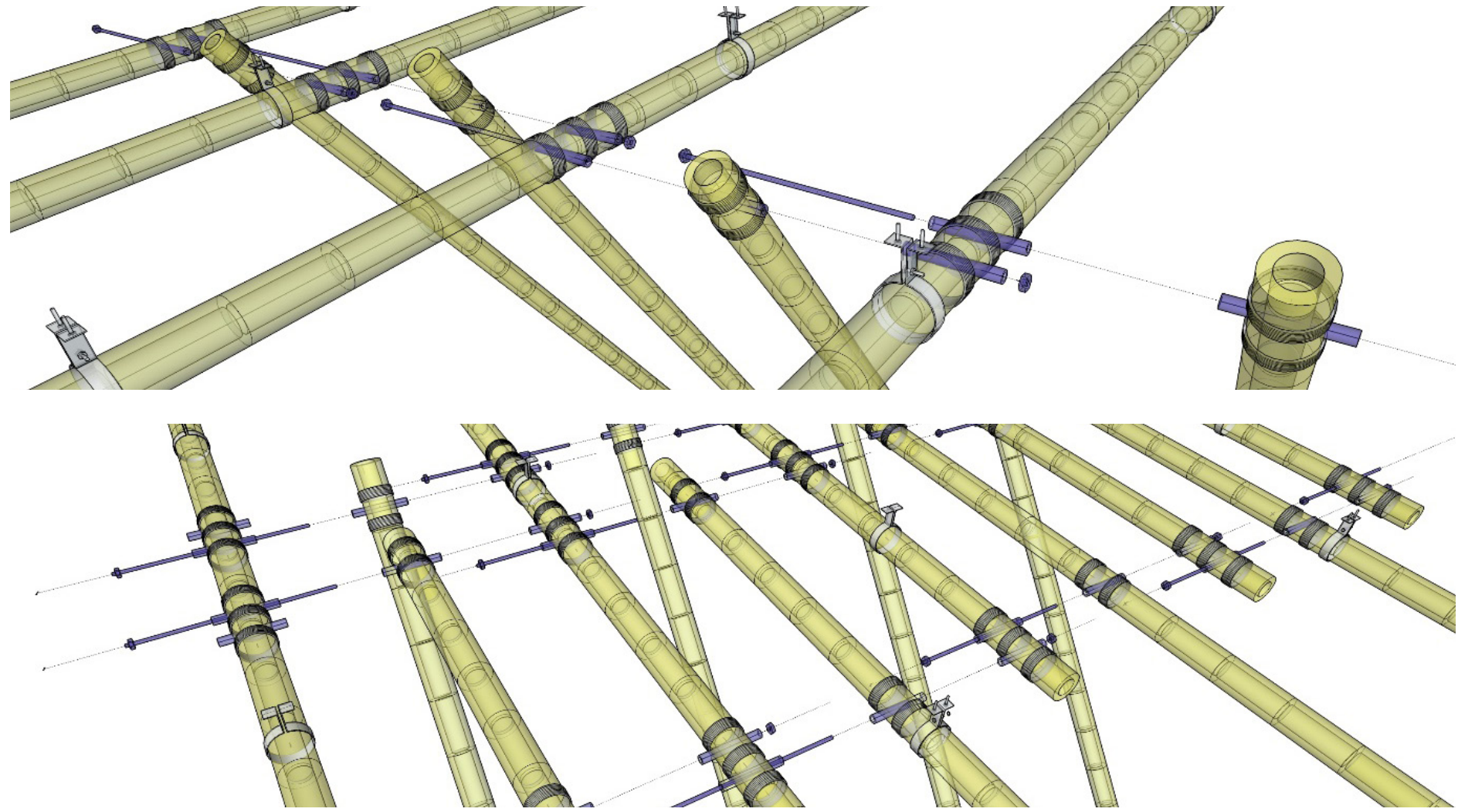

FIGURA 12

Montagem das

conexões 1 e 2 .

Montagem da

conexão 1. 


\section{Conexões 3 e 4}

Essas conexões são tecnicamente similares, mas ocorrem em situações diferentes. São as conexões de bambu com eucalipto. A conexão 3 (Figura 12) une os colmos diagonais com as vigas de eucalipto. A conexão 4 une as pernas do telhado com a cumeeira de eucalipto (Figura 14)

Uma cavilha atravessa transversalmente o colmo pelo seu centro da seção. Uma barra com a extremidade em forma de gancho é pendurada na cavilha por meio de um furo no internó e a cavidade é preenchida com graute, dando rigidez às peças metálicas e ajudando, por contato interno da parede, a transmitir os esforços axiais do colmo para o elemento complementar metálico, que possui uma parte rosqueada no final, atravessando o eucalipto pelo meio da seção circular, e o fixa por meio de uma porca. É tampado com um pedaço de madeira.

Acima e abaixo das cavilhas são colocadas braçadeiras de fibras de propileno para comprimir radialmente o colmo e evitar possíveis fendilhamentos.

O colmo é apoiado sobre da viga de eucalipto, transmitindo os esforços de compressão. A conexão, teoricamente, é articulada, mas sempre existe um pouco de momento fletor que, se a conexão não estiver bem executada, poderá danificar o bambu.

Perto das cavilhas são colocadas braçadeiras de fibras de polipropileno que comprimem radialmente o colmo evitando o fendilhamento nas regiões mais frágeis, neste caso é a superfície de contato entre a cavilha de aço e a parede do colmo.(Figura 13)

Essa conexão é um híbrido entre as conexões do Grupo 2 de Janssen (2000), que são conexões do interior para um elemento paralelo, e do Grupo 4, conexões de seção transversal para elemento perpendicular. Desde o ponto de vista $d$ a complexidade tecnológica são do nível 3

Poderia se tratar de uma modificação da conexão com parafuso extensor apresentada por Dunkelberg (1996).

\section{Conexão 5}

A Conexão 5 é formada pelo bambu e uma braçadeira metálica fechada pela parte superior, na qual se apoiam as longarinas. Esse sistema gera uma compressão perpendicular âs fibras que ajuda os colmos a resistirem a trações transversais e cisalhamentos que possam ter origem no momento fletor criado pelo peso próprio dos colmos pelo peso de telhas e longarinas.

Essa conexão insira-se no Grupo 7 - Conexões feitas pela transmissão de esforços pelo exterior do colmo por meio de um elemento complementar perpendicular. Jayanetti e Follett (1998) a catalogam com o nome de Das Clamp. Sob o ponto de vista da complexidade tecnológica são do nível 3. 

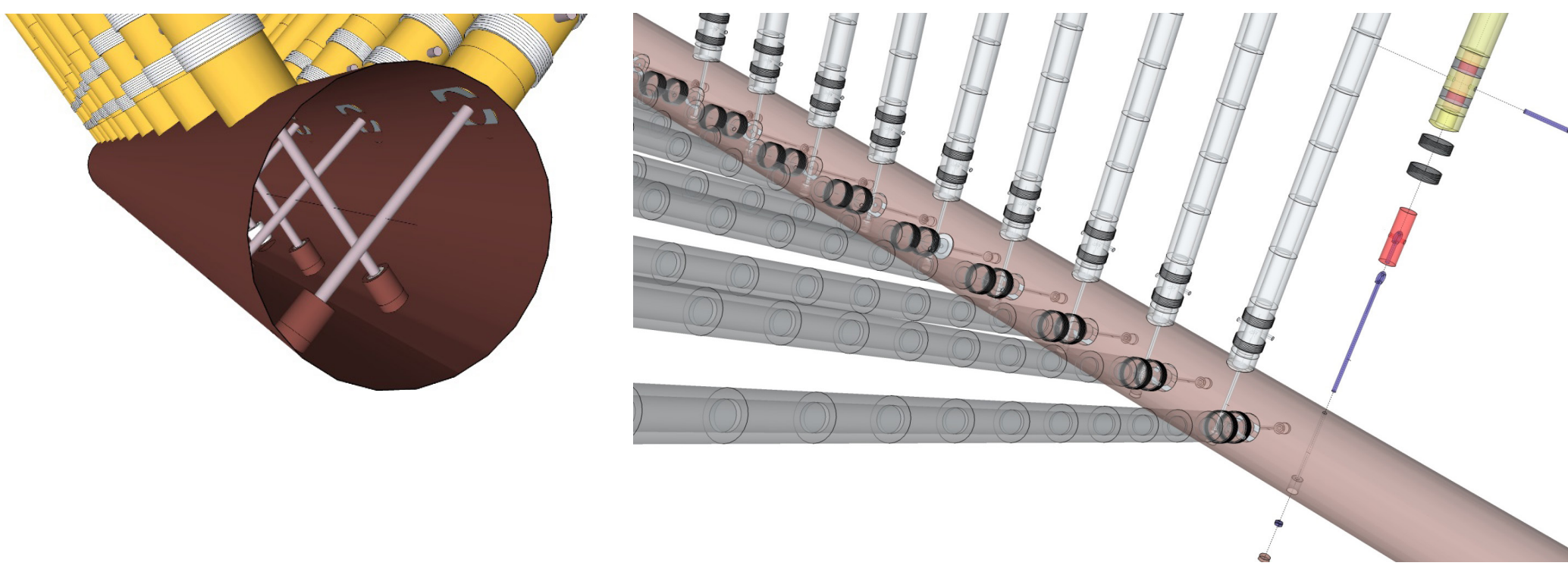

FIGURA 13

Corte da viga de eucalipto com a conexão 3. Autor: Joan Font.

FIGURA 14

Montagem da conexão 3. Autor: Joan Font.
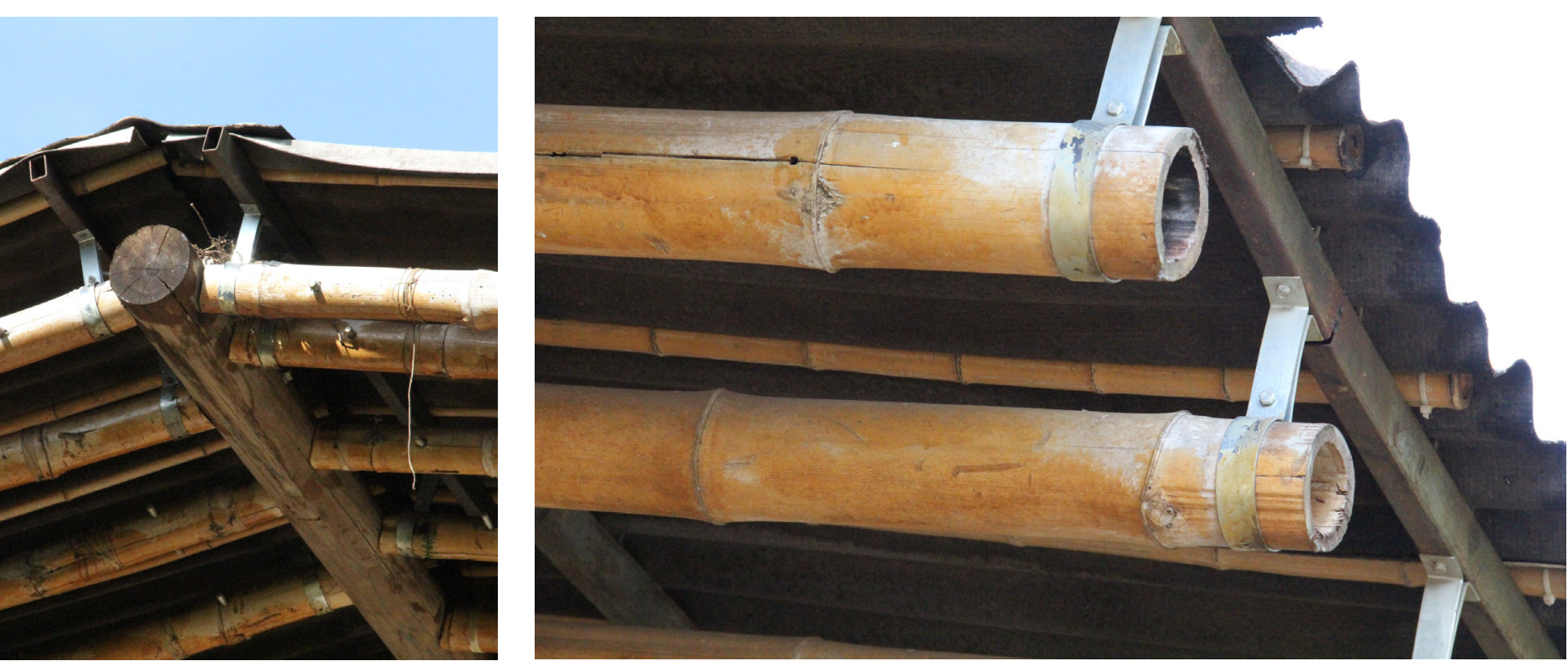

FIGURA 15

Detalhe conexão 4. Foto: Joan Font.

FIGURA 16

Imagem da conexão 5.

Foto: Joan Font. 


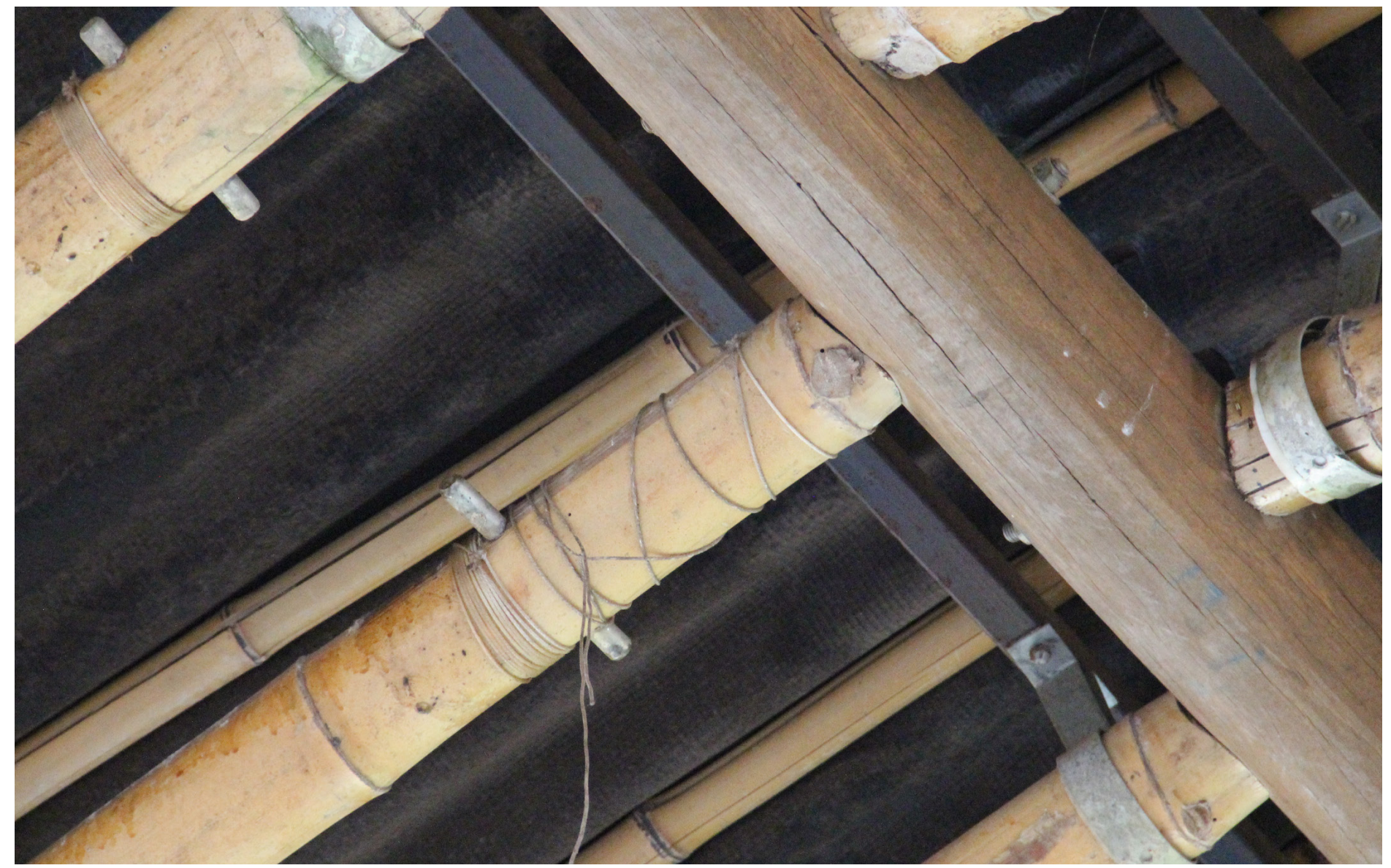




\section{Descrição por inspeção visual}

Corda de propileno para compressão radial do colmo estava desamarrada (Figura 17).

\section{Causa provável}

a) Amarração incorreta da corda (execução);

b) Material defeituoso (fornecedor).

Todos os colmos de bambu, quando há uma conexão, possuem essas braçadeiras de reforço, e a maioria estão intactas, poucas se desamarraram. Mas não é possível determinar se foi uma falha do material ou da execução.

\section{A patologia pode influir no(s) seguinte(s) fator(es) \\ - Segurança estrutural; \\ - Durabilidade.}

\section{Mecanismo de ocorrência}

A corda de fibras de polipropileno colocada para aumentar a resistência à tração perpendicular às fibras no colmo do bambu se desamarrou. Essa amarração exerce uma compressão radial no colmo que alivia as cavilhas perpendiculares.

A amarra diminui a possibilidade de fendilhamento do colmo, causado pela concentração de carga transmitida da cavilha à seção da parede do furo do colmo.

Em caso de o colmo fendilhar, a amarração garante a forma do colmo e evita que ele entre em colapso, portanto, contribui para a estabilidade estrutural.

\section{Para a correção dessa} manifestação patológica deve-se

- Verificar se houve fendilhamento no furo da conexão e, em caso afirmativo, é recomendável trocar o colmo, não por comprometer a estabilidade estrutural, mas porque pode ser mais facilmente atacado por agentes biológicos;

- Verificar o material da amarração;
- Amarrar novamente a braçadeira. Para a prevenção de novas patologias semelhantes deve-se

- Verificar as amarrações uma por uma;

- Verificar o material antes de ser executado;

- Executar adequadamente a amarração conforme o resto de vínculos da estrutura. 


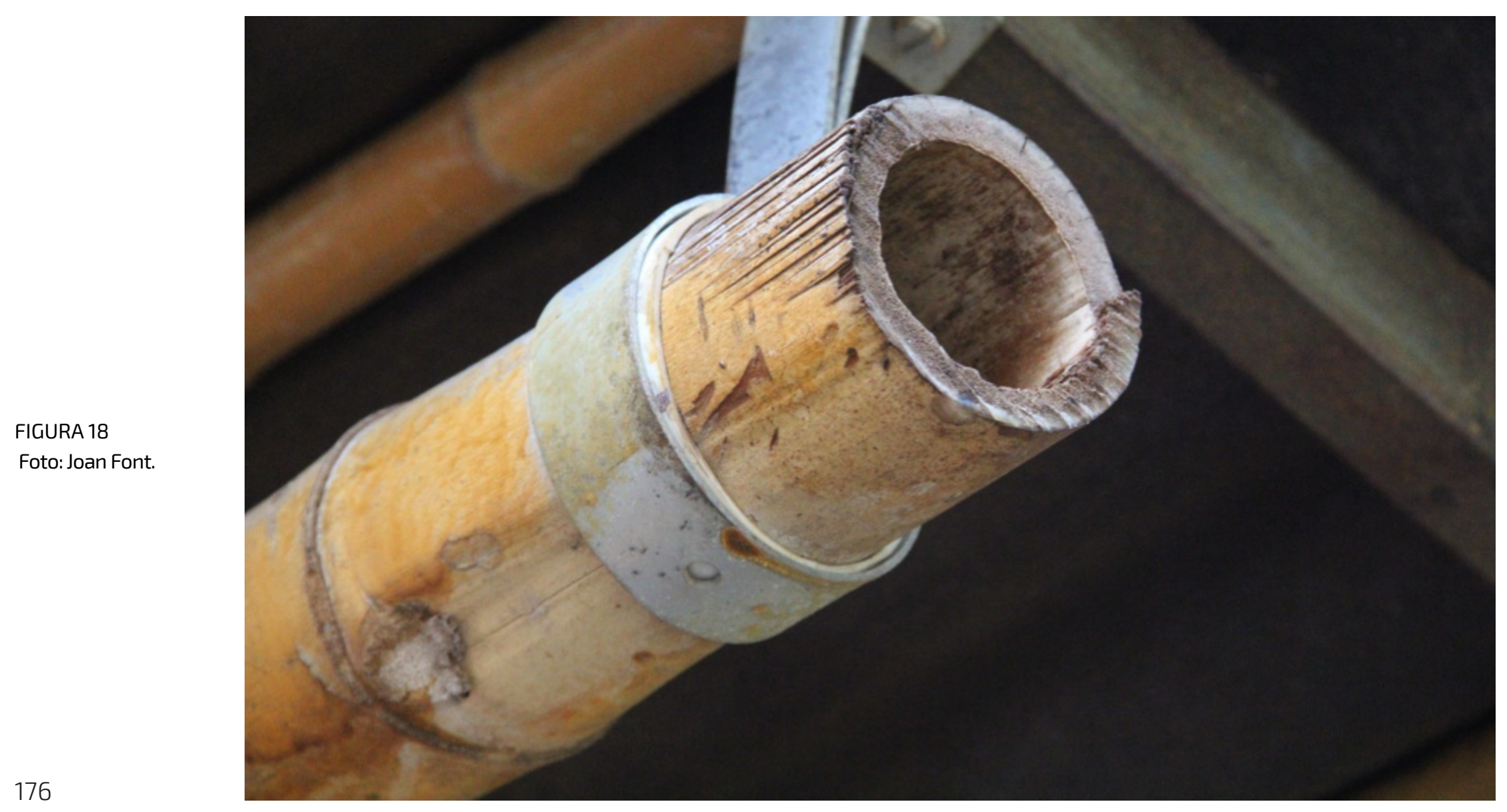




\section{Descrição por inspeção visual}

Desfibramento do colmo na extremidade exposta às intempéries (Figura 18).

\section{Causa provável}

a) Corte incorreto e prematuro do colmo no abate e no processamento (Fornecedor).

b) Exposição às intempéries da extremidade do colmo (Projeto).

\section{Mecanismo de ocorrência}

O corte dos colmos de bambu é muito mais fácil e mais limpo quando o TU está abaixo do PSF. Quando o bambu é manipulado com um TU acima de $20 \%$, as fibras podem se desagregar facilmente durante a serragem, facilitando a posterior entrada de água e outros agentes ambientais.

No caso, o fato de as extremidades estarem no final do beiral e estarem expostas às intempéries acelerou o processo de desagregação das fibras e de degradação dos tecidos.

As variações de umidade, assim como a radiação solar direta, provocam tensões no parênquima do bambu, aumentando a desfibração e favorecendo aparição de fungos.

Ao ocorrer a degradação na extremidade do colmo, onde não existe nenhum tipo de esforço, permite não haver nenhum tipo de efeito comprometedor à estabilidade estrutural.

\section{A patologia pode influir no(s)} seguinte(s) fator(es):

- Durabilidade;

- Estanqueidade (do colmo);

- Conforto visual.

Para a correção dessa manifestação patológica deve-se:

- Proteger mecanicamente a extremidade do colmo com alguma luva plástica ou elemento que o cubra e evite o contato com às intempéries.

Para a prevenção de novas patologias semelhantes deve-se

- Controle de qualidade e execução correta do corte no momento de secagem correta por parte do fornecedor;

- Utilizar diretrizes de design que evitem a exposição parcial ou total de colmo às intempéries. 
FIGURA 19

Foto: Joan Font.

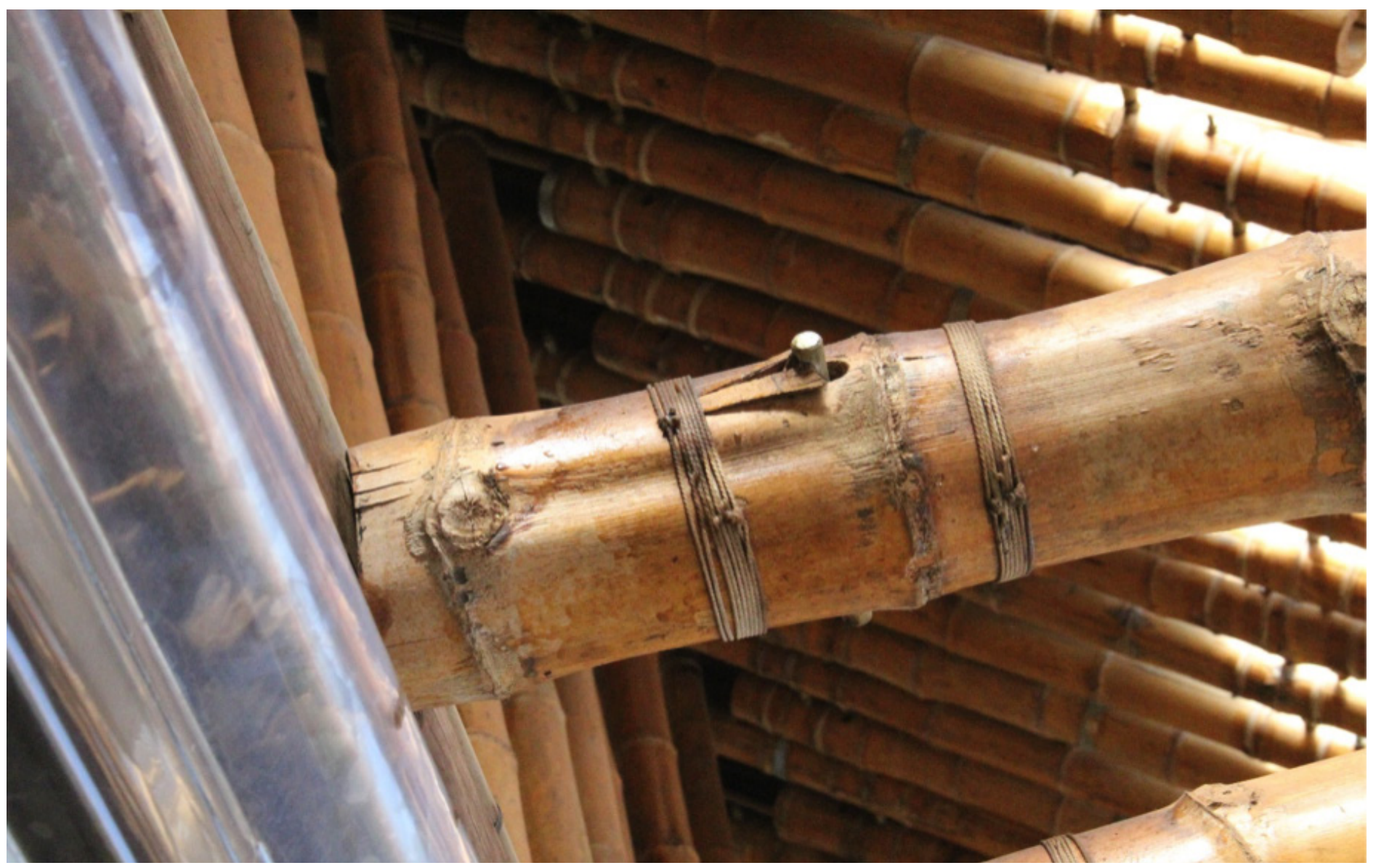




\section{Descrição por inspeção visual}

Deterioração e colapso da parede da região do furo do colmo mais próximo do eucalipto (Figura 19).

\section{Causa provável}

Tensão não admitida pelo bambu na pressão exercida pela cavilha metálica, devido a esforços de tensão provocados pela tração da conexão

\section{Mecanismo de ocorrência}

Segundo a análise do modelo estrutural, o efeito de sucção, se for muito violento, pode ser mais intenso que o próprio peso da estrutura, fazendo com que certos componentes trabalhem a tração. Nesse caso, a tração do colmo exerceu uma pressão que deslocou o graute que existe dentro do internó, provocando uma pressão da cavilha contra a parede do furo do colmo, fazendo-o colapsar por cisalhamento interlaminar (projeto).

\section{A patologia pode influir no(s)} seguinte(s) fator(es):

- Segurança estrutural;

- Durabilidade;

- Estanqueidade (do colmo).

\section{Para a correção dessa manifesta-} ção patológica deve-se:

- Trocar o elemento inteiro. Por ser uma construção seca, facilita o aproveitamento das ferragens dos vínculos.

Para a prevenção de novas patologias semelhantes deve-se:

- Reforçar a conexão evitando movimentações e deslizamentos e considerando uma força de sução mais elevada no cálculo. 



\section{Descrição por inspeção visual}

Existe uma distância entre o bambu e a viga de eucalipto. O colmo de bambu deveria repousar sobre da viga de eucalipto, mantendo contato pleno da seção do colmo com a madeira. Dessa forma, a transmissão de cargas da cobertura se faz unicamente pelo conector metálico que os une (Figura 20).

\section{Causa provável}

a) Falha na execução da conexão;

b) Deformação da cobertura pelo efeito de sucção do vento (projeto).

\section{Mecanismo de ocorrência}

A barra de aço transversal foi inserida no vínculo muito perto do final do colmo, já que tem de estar perto de um internó. A barra que une a cavilha metálica com a viga de eucalipto tem uma medida padronizada, e ficou muito mais comprida do que a distância necessária para que o colmo descarregasse sobre a viga. É sempre recomendável ter as conexões, no mínimo, a $6 \mathrm{~cm}$ do nó, como aconselha, por exemplo, a norma peruana (NTE-100).

Segundo a análise do modelo estrutural, o efeito de sucção, se for muito violento, pode ser mais intenso que o peso próprio da estrutura. Isso forçaria certos componentes a trabalharem à tração. Nesse caso, a tração deslocou a porca que segura a barra rosqueada dentro do eucalipto e travou, deixando o colmo nessa posição, uma vez que terminaram as ações de sucção do vento.

\section{A patologia pode influir no(s) seguinte(s) fator(es)}

- Segurança estrutural;

- Durabilidade;

- Estanqueidade do colmo.

Para a correção dessa manifestação patológica deve-se

- Trocar o elemento inteiro. Por ser uma construção seca, facilita o aproveitamento das ferragens dos vínculos;

- Colocar calços em toda a circunferência do final do colmo para facilitar o contato entre o bambu e o eucalipto e amarrá-los com uma braçadeira. Deve-se maximizar a superfície de contato, para evitar cargas concentradas;

- Tracionar a barra rosqueada dentro do eucalipto para voltar o colmo à posição original. 
FIGURA 21

Foto: Joan Font.

182

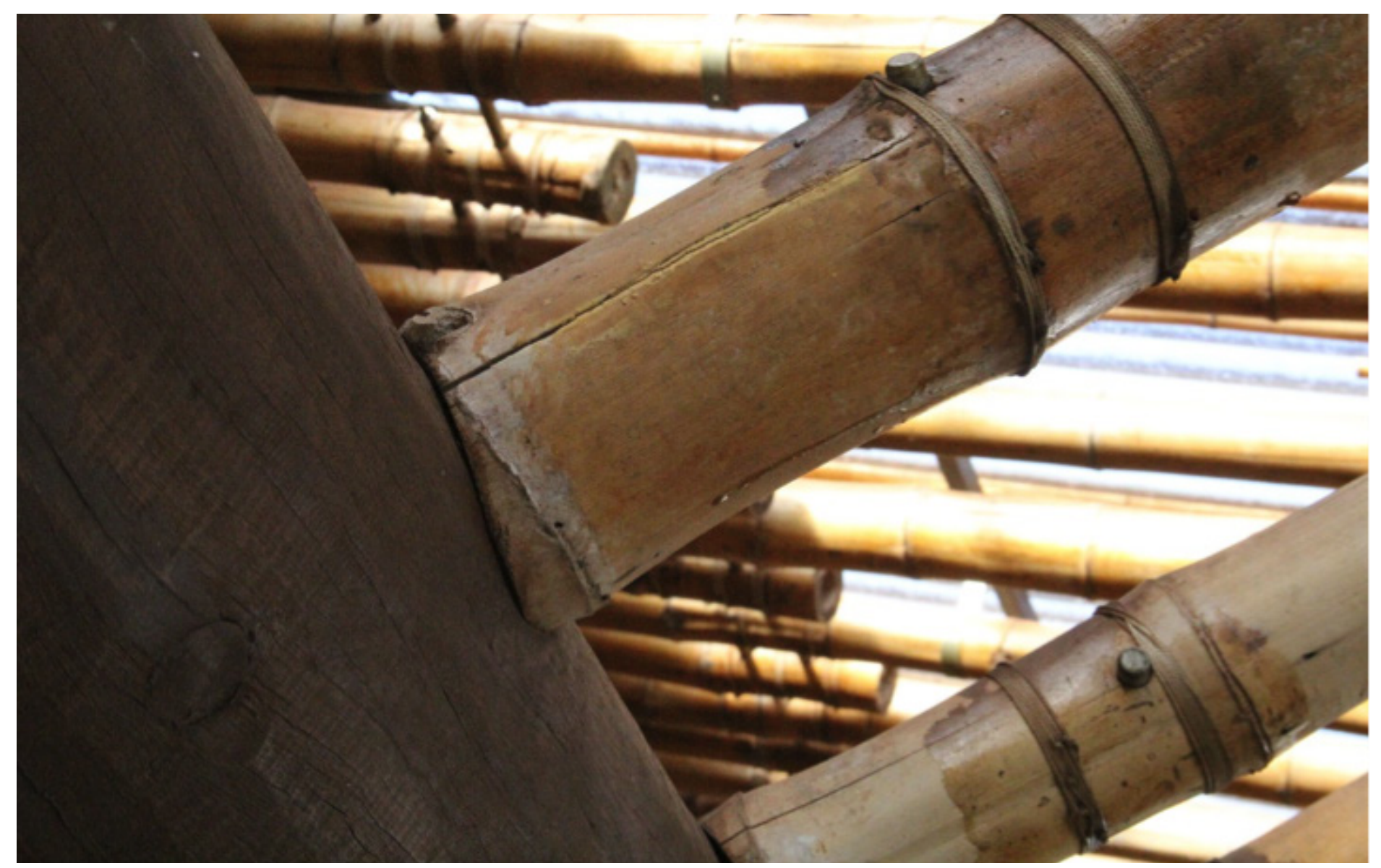




\section{Descrição por inspeção visual}

Fissura do colmo com origem na extremidade em contato com a viga de eucalipto até o primeiro nó (Figura 21).

\section{Causa provável}

Apoio incorreto da seção do bambu em cima da viga de eucalipto (execução).

\section{Mecanismo de ocorrência}

$\mathrm{O}$ corte de boca-de-peixe no bambu para encaixá-lo perpendicularmente a outro elemento cilíndrico precisa de um cuidado especial, porque, no momento de verificar se o apoio acontece na superfície máxima de contato ou pelo contrário, é apoiado parcialmente.

Existe uma excentricidade na transmissão dos esforços do colmo para a viga de eucalipto, e essa carga mal distribuída faz com que só uma parte do colmo esteja transmitindo esforços de compressão. Essa tensão diferencial pode gerar um esforço cortante paralelo às fibras do bambu e um esforço de tração perpendicular às mesmas. Em ambos os casos, supera-se o estado limite último e se manifesta o efeito por meio de uma rachadura.

Deve-se dar especial atenção a tal tipo de patologia, uma vez que a estrutura entra em regime de serviço, pois podem ocorrer deformações não previstas.

\section{A patologia pode influir no(s) seguinte(s) fator(es)}

- Segurança estrutural;

- Durabilidade;

- Estanqueidade (do colmo).

\section{Para a prevenção de novas pato-} logias semelhantes deve-se

- Aprimorar o corte de boca-de- peixe e fazer as correções necessárias assim que seja verificada a deformação quando a estrutura entra em regime de serviço.
Para a correção dessa manifestação patológica deve-se

- Remover o colmo, aprimorar o corte de boca-de-peixe e colocar uma braçadeira para evitar uma fenda maior;

- Ou, então, trocar o colmo inteiro dando especial atenção ao corte em boca-de-peixe.

- Preencher o espaço com poliuretano 
FIGURA 22

Foto: Joan Font.

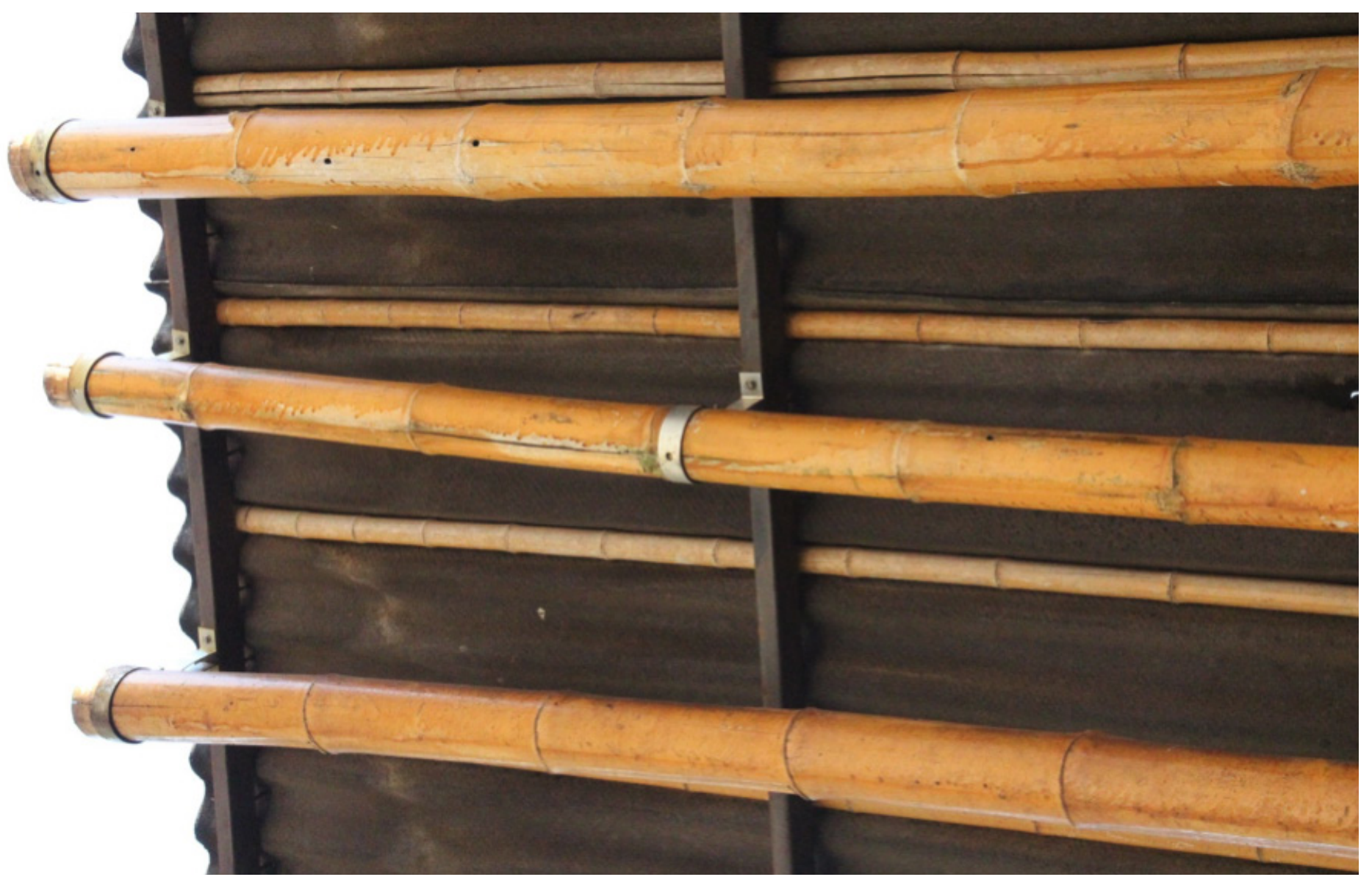




\section{Descrição por inspeção visual}

Colmo não retilíneo, com desvio excepcional da sua geometria (Figura 22).

\section{Causa provável}

Seleção incorreta do material em obra (execução).

\section{Mecanismo de ocorrência}

$\mathrm{O}$ executor considerou o colmo adequado durante a fase de construção quando são descartados aqueles colmos que não têm aptidão para constituir a estrutura por causa de rachaduras, degradações e geometrias irregulares. A curvatura não originou problemas na estabilidade da estrutura nem do elemento contíguo.

Por exemplo, a norma peruana E-100 sobre construção de bambu não permite a utilização de peças que apresentem deformação maior que 0,33\% do comprimento do elemento. Este colmo tem um comprimento de $5,8 \mathrm{~m}$ e um desvio de $10 \mathrm{~cm}$. Isso supõe um $1,7 \%$ de excentricidade, o que não seria apto segundo os critérios peruanos.

\section{A patologia pode influir no(s) seguinte(s) fator(es)}

- Conforto visual.

Para a correção desta manifestação patológica deve-se

- Trocar o colmo ou submetê-lo a tratamento por calor para corrigir sua forma não retilínea

Para a prevenção de novas patologias semelhantes deve-se Selecionar adequadamente os colmos durante a obra. 
FIGURA 23

Foto: Joan Font.

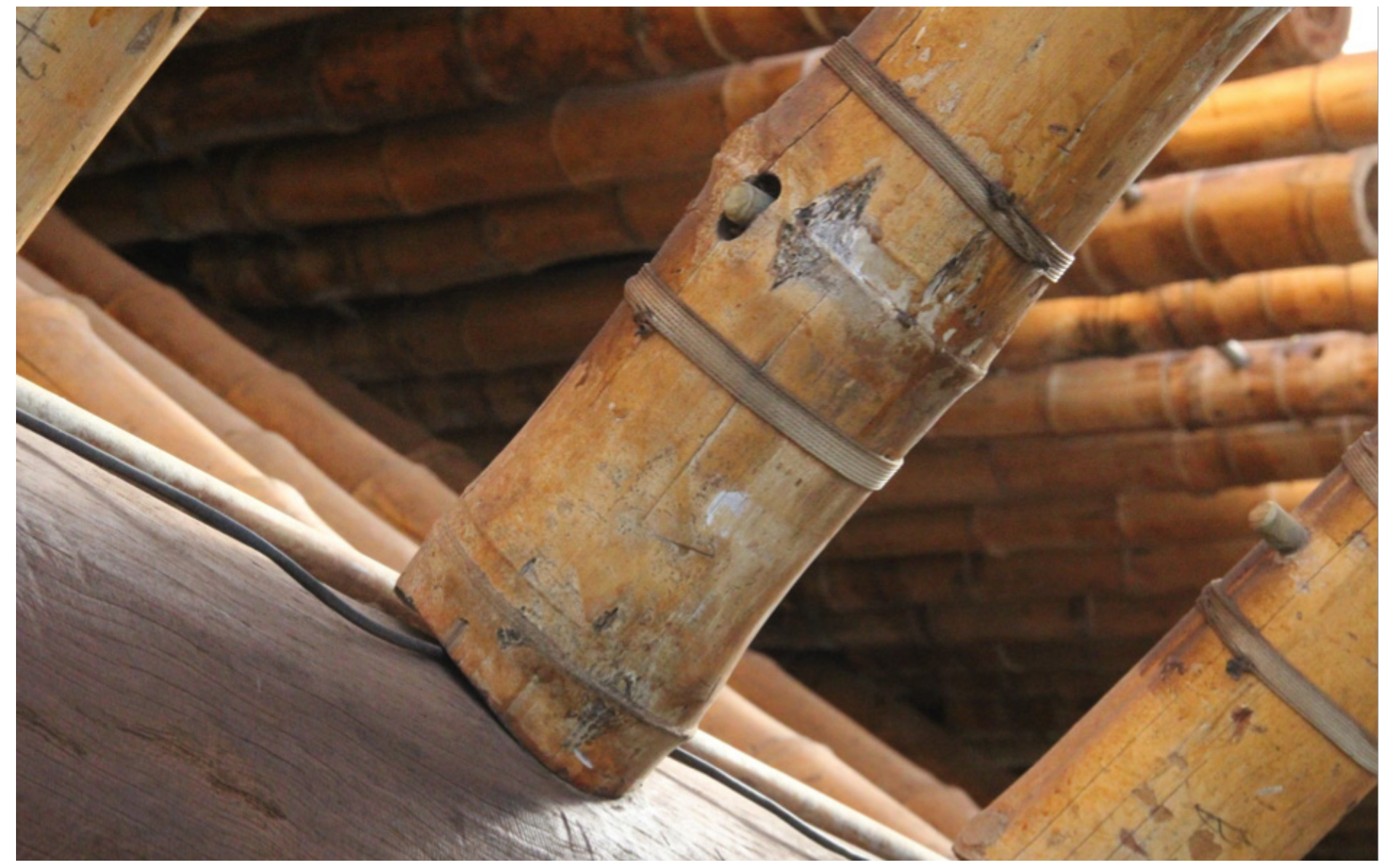




\section{Descrição por inspeção visual}

Furo excessivamente grande para a fixação da cavilha metálica na conexão bambu-eucalipto (Figura 23).

\section{Causa provável}

Execução errada e deslocada do furo no colmo onde passa a cavilha.

\section{Mecanismo de ocorrência}

Planejamento errado na execução dos furos para a conexão. Fez-se o furo na posição equivocada e teve de ser refeito sem o descarte do colmo, deixando a cavidade muito maior do que seria necessário.

Isto impede o contato entre a parede do colmo e a cavilha, criando uma conexão pouco rígida e que teve como consequência o deslocamento do colmo e o apoio incorreto dele na viga de eucalipto.
- Estanqueidade do colmo.

Para a correção dessa manifestação patológica deve-se:

- Trocar o colmo e executar corretamente a conexão;

- Preencher o orifício com algum material que permita a transmissão de esforços do bambu para a cavilha.

\section{A patologia pode influir no(s)} seguinte(s) fator(es)

- Segurança estrutural;

- Durabilidade; 
FIGURA 24

Foto: Joan Font

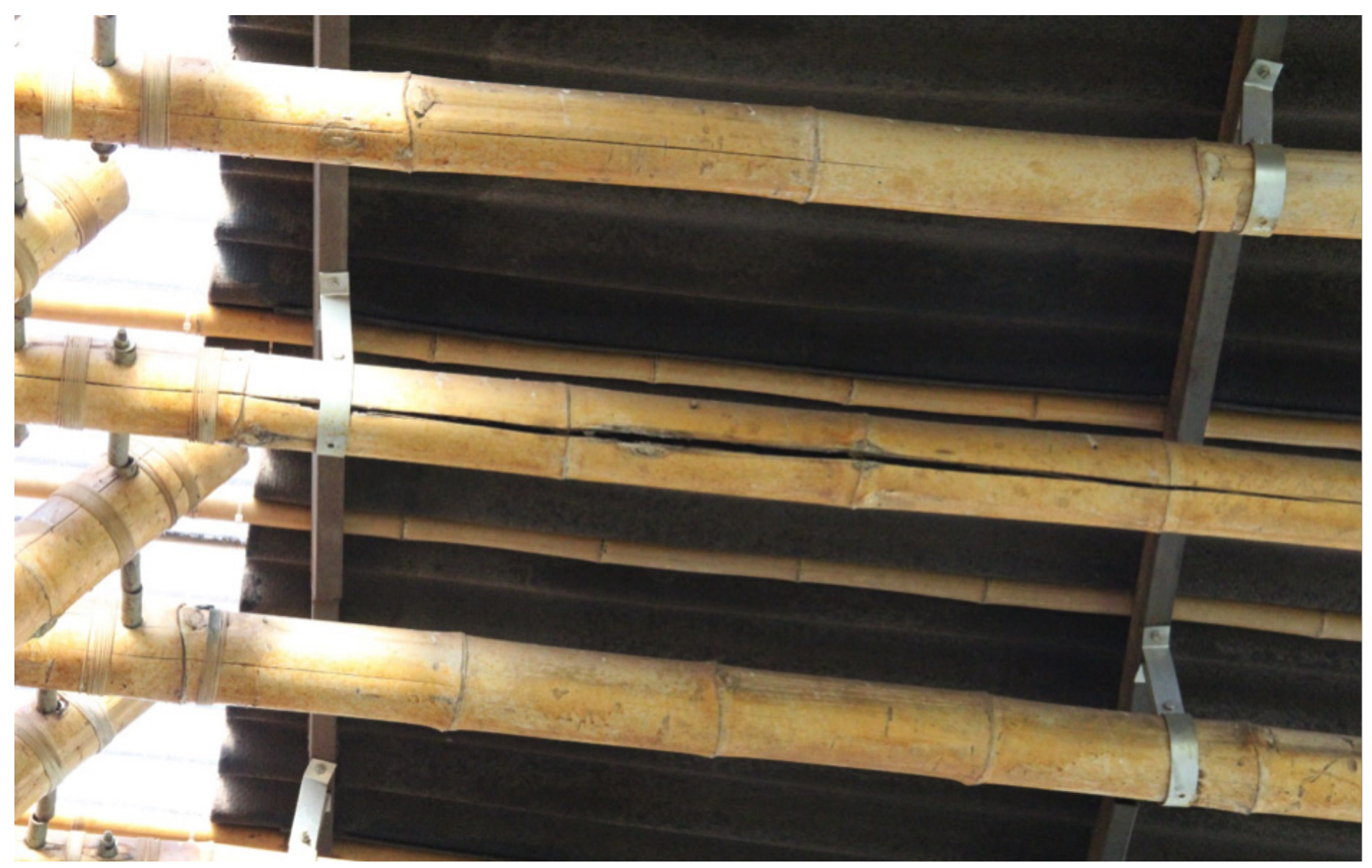




\section{Descrição por inspeção visual}

Rachadura longitudinal de quase 1 $\mathrm{cm}$ de abertura e comprimento de, aproximadamente, 1,5 m, com partes internas da rachadura deterioradas e com manchas pretas.

Furos no córtex de 0,5 cm de diâmetro (Figura 24).

\section{Causa provável}

Ataque por parte de algum agente biológico xilófago. Provocado por uma manutenção deficiente ou por um tratamento deficiente (fornecedor).

\section{Mecanismo de ocorrência}

$\mathrm{O}$ amido remanescente do colmo, e que dificilmente pode ser eliminado do bambu durante o processamento, atraiu algum inseto xilófago que penetrou no interior do bambu, utilizando-o como fonte de alimento, consumindo parte da sua parede interna, onde o tecido é mais macio, e diminuindo sua resistência mecânica.
O colmo funciona com perna do telhado e está submetido a momentos fletores e cisalhamento. Quando o colmo tem diminui drasticamente sua massa, já não possui mais capacidade para resistir aos esforços para os quais foi projetado e colapsa fendilhando na direção paralela às fibras.

\section{A patologia pode influir no(s)}

seguinte(s) fator(es)

- Segurança estrutural;

- Durabilidade;

- Estanqueidade (do colmo).

Para a correção dessa manifestação patológica deve-se

- Trocar o colmo de bambu danificado.

Para a prevenção de novas patologias semelhantes deve-se

- Realizar o tratamento preservativo por imersão em solução de derivados do boro adequadamente;

- Verificar a qualidade com o fornecedor na entrega do material. 
FIGURA 25

Foto: Joan Font.

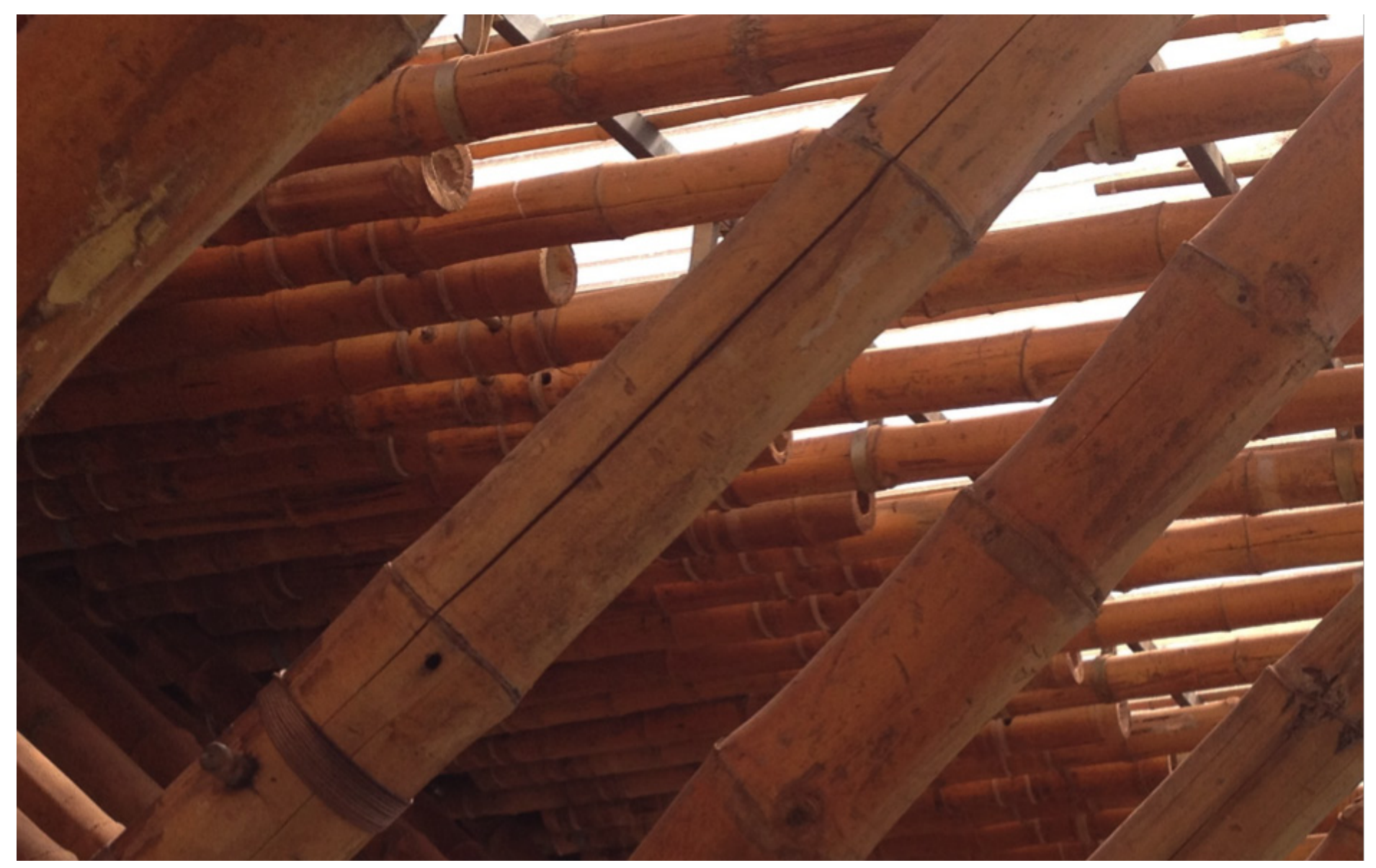




\section{Descrição por inspeção visual}

Rachadura do colmo de bambu submetido à flexocompressão pela linha neutra (Figura 25).

\section{Causa provável}

Flexão não controlada do colmo e transmissão de momentos fletores ou cisalhamento não previstos.

\section{Mecanismo de ocorrência}

A estrutura está concebida para que não haja momentos fletores nas conexões nem nos colmos que fazem a descarga de forças das telhas na viga de bambu. Contudo, é impossível garantir conexões absolutamente articuladas que permitam a transmissão pura de esforços axiais.

Nesse caso, a rigidez das conexões desse colmo originou tensões de flexocompressão e de cisalhamento de uma magnitude superior à sua tensão limite, provocando a fratura e o fendilhamento pela linha neutra do colmo.

\section{A patologia pode influir no(s)} seguinte(s) fator(es)

- Segurança estrutural;

- Durabilidade;

- Estanqueidade do colmo.

\section{Para a correção dessa manifesta-} ção patológica deve-se

- Trocar o colmo e executar corretamente a conexão;

- Colocar braçadeiras que comprimam radialmente o colmo e evitem a extensão da fenda.

\section{Para a prevenção de novas pato-}

logias semelhantes deve-se

- Projetar e utilizar conexões mais flexíveis com menos rigidez;

- Colocar braçadeiras preventivas que comprimam o colmo transversalmente. 
FIGURA 26

Foto: Joan Font.

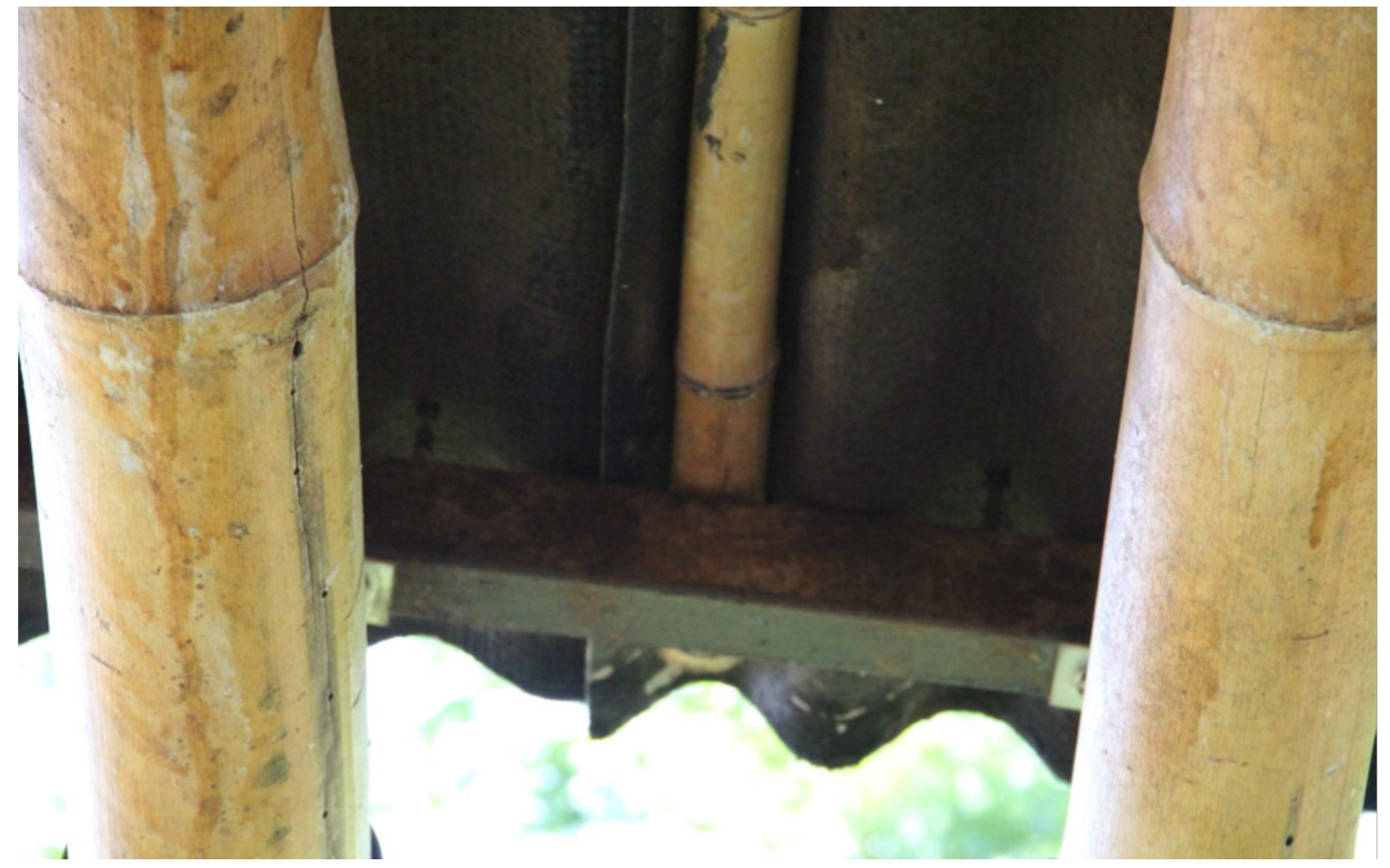




\section{Descrição por inspeção visual}

Fenda que percorre a parede do colmo unindo diferentes perfurações da parede (Figura 26).

\section{Causa provável}

Ataque biológico de caruncho Dinoderus minutus, segundo os responsáveis do Centro Cultural.

A causa pode ser originada pelo defeito de tratamento do fornecedor. E pela deficiência na manutenção, não realizando dedetizações periódicas.

\section{Mecanismo de ocorrência}

Os insetos atacam o bambu procurando alimento, realizando perfurações próximas, provocando a fragilização da capacidade mecânica do bambu. Ao serem os furos contíguos no eixo axial do colmo, as tensões originadas pelas cargas suportadas originam o colapso do parênquima pela região mais débil, rachando o material e interligando os orifícions existentes.

\section{A patologia pode influir no(s)} seguinte(s) fator(es)

- Segurança estrutural;

- Durabilidade;

- Estanqueidade (do colmo).

\section{Para a correção desta manifesta-} ção patológica deve-se

- Trocar o colmo de bambu danificado.

\section{Para a prevenção de novas pato-}

logias semelhantes deve-se

- Realizar o tratamento preservativo por imersão em solução de derivados do boro adequada;

- Verificar a qualidade com o fornecedor na entrega do material. 
FIGURA 27

Foto: Joan Font.

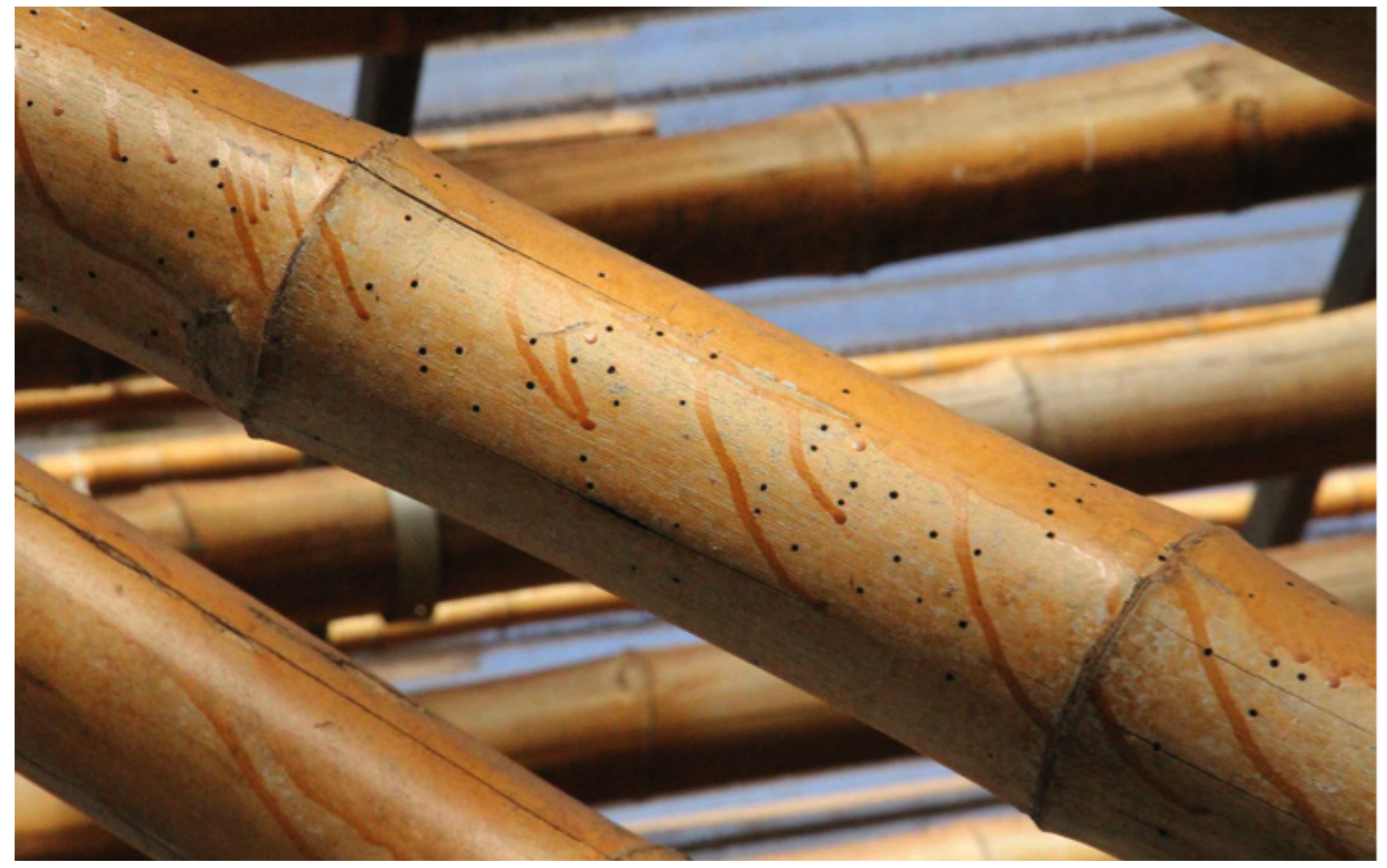




\section{Descrição por inspeção visual}

Grande quantidade de orifícios de 1 $\mathrm{mm}$ de diâmetro ao longo do colmo.

O colmo foi excessivamente atacado por insetos, que provocaram perfurações na estrutura do colmo, o que facilita as rachaduras e provoca a instabilidade do colmo (Figura 27).

\section{Causa provável}

Bambu sem tratamento ou tratamento defeituoso (fornecedor).

\section{Mecanismo de ocorrência}

Ao não ser aplicado o tratamento preservativo, o bambu não tem impregnado nos tecidos substâncias tóxicas que dissuadam os agentes biológicos xilófagos de perfurar o material para consumir o amido nele armazenado.

Graças a entrevistas com a arquiteta do projeto, foi relatado que alguns colmos adquiridos não tinham sido adequadamente tratados por imersão de octaborato de sódio ade- quado como o resto. Durante a construção foram descartados aqueles colmos que já apresentavam sinais de ataques.

\section{A patologia pode influir no(s)}

seguinte(s) fator(es)

- Segurança estrutural;

- Durabilidade;

- Estanqueidade (do colmo);

- Conforto visual.

Para a correção desta manifestação patológica deve-se

- Trocar o colmo de bambu danificado.

\section{Para a prevenção de novas pato-}

\section{logias semelhantes deve-se}

- Realizar o tratamento preservativo por imersão em solução de derivados do boro adequada;

- Verificar a qualidade com o fornecedor na entrega do material. 
FIGURA 28

Foto: Joan Font.

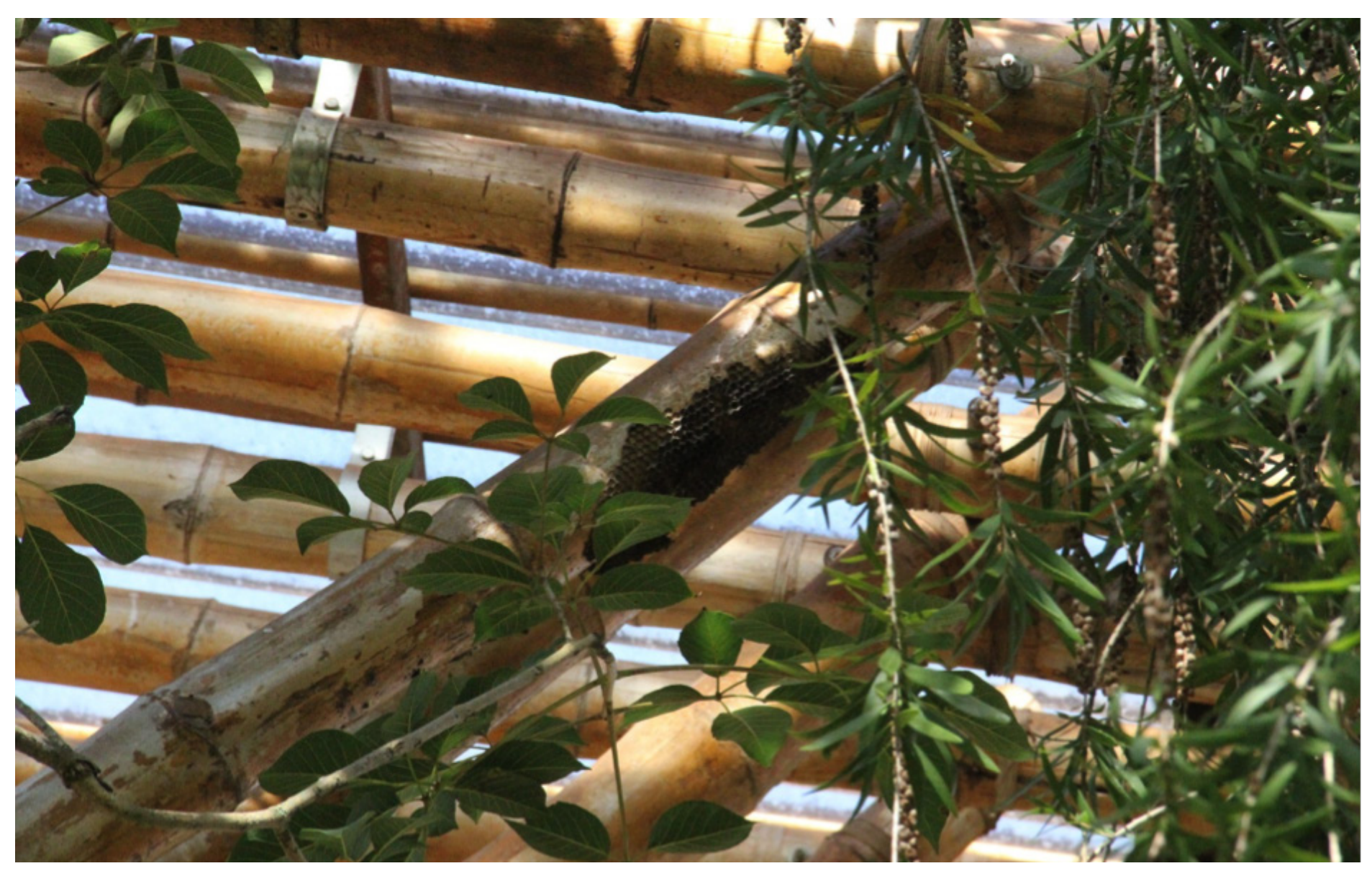


Descrição por inspeção visual

Colmeia grudada no córtex do

bambu lateral (Figura 28).

\section{Causa provável}

Degradação do córtex e mudança de textura em um contexto protegido dos efeitos das intempéries (manutenção e projeto).

\section{Mecanismo de ocorrência:}

Devido à degradação do córtex, a superfície externa do bambu perdeu aderência, facilitando a fixação de uma colônia silvestre de abelhas.

A posição do colmo situado na lateral sudoeste da cobertura, estando desprotegido dos efeitos da chuva, provocou a deterioração.

A proximidade de vegetação de grande porte (árvore), que protege o colmo, mantém a umidade e evita a radiação direta solar, proporcionou o microclima adequado para os insetos criarem sua colônia.

\section{A patologia pode influir no(s)} seguinte(s) fator(es)

- Conforto visual;

- Saúde e habitabilidade do usuário.

\section{Para a correção desta manifesta-} ção patológica deve-se

- Remoção da colmeia;

- Instalar algum mecanismo de proteção lateral da cobertura - pode ser por meio de telhas, toldo ou outro elemento que se adapte à linguagem arquitetônica do edifício.

Para a prevenção de novas patologias semelhantes deve-se

- Projetar qualquer estrutura de bambu com colmos aparentes de forma a não estar expostos sob qualquer circunstância às intempéries.

- Prever beirais 1,5 vez a altura do bambu que está sujeito à exposição. 
FIGURA 29

Foto: Joan Font.

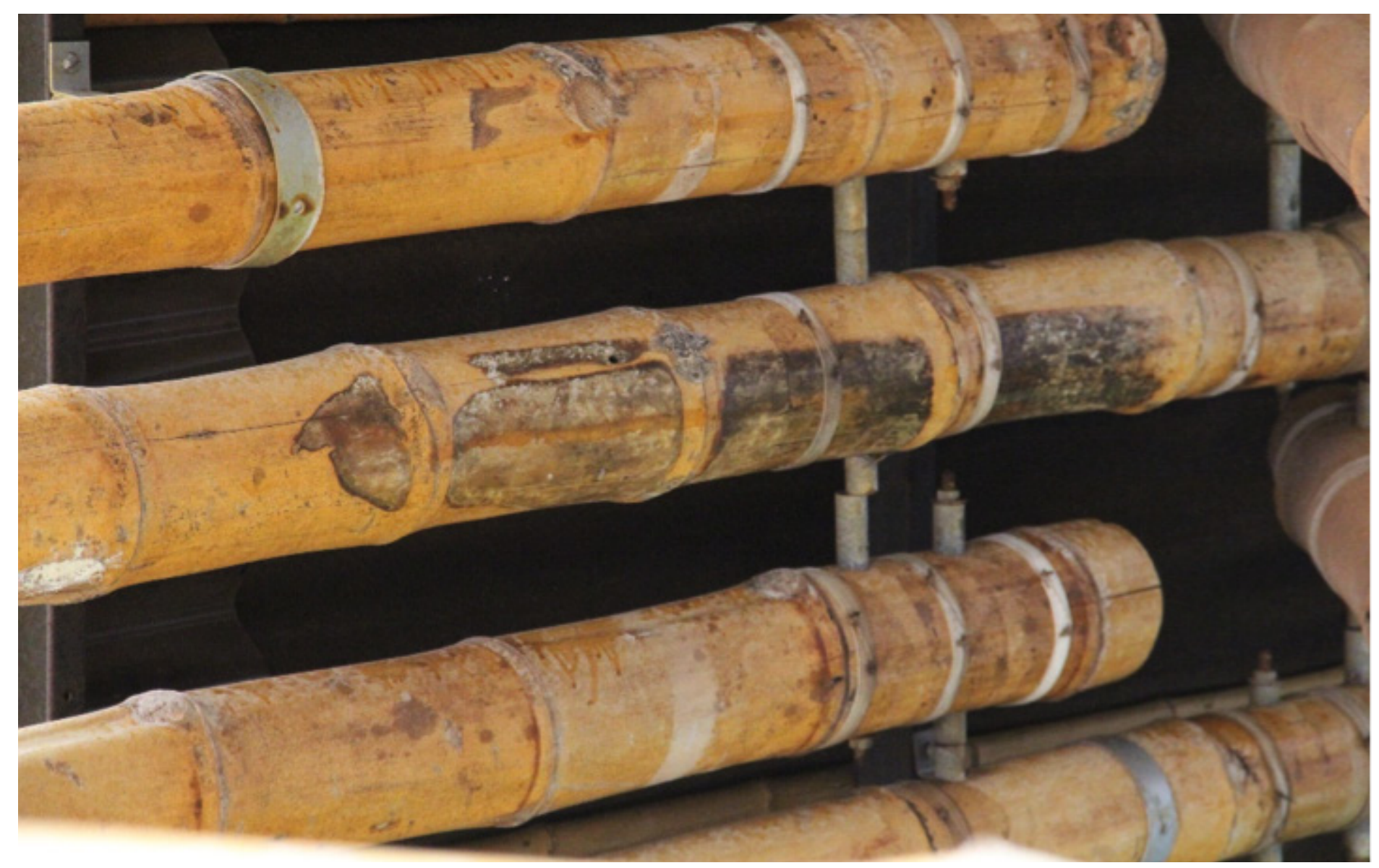




\section{Descrição por inspeção visual}

Degradação localizada no córtex e escurecimento das paredes desprotegidas do colmo (Figura 29).

\section{Causa provável}

Bambu excessivamente maduro (fornecedor)

\section{Mecanismo de ocorrência}

O bambu neste caso foi colhido num estado de maturação muito avançado. Não é recomendável colher bambus com mais de 7 anos, pois, a partir de certa idade, começa um processo de degradação natural dos tecidos que afetam suas propriedades mecânicas.

Por outro lado, a patologia pode ser relacionada ao conforto visual do que à diminuição do desempenho estrutural, pois não se apresentam fissuras nem rachaduras. Pode-se observar que o córtex está visivelmente afetado e deteriorado, permitindo mais penetração de umidade no interior do colmo.

\section{A patologia pode influir no(s)} seguinte(s) fator(es)

- Durabilidade;

- Estanqueidade (do colmo);

- Conforto visual.

\section{Para a correção dessa manifesta-} ção patológica deve-se

- Recomenda-se a troca do colmo inteiro;

- Aplicação de verniz para proteção, evitando a penetração de umidade, e colocação de braçadeiras para evitar possíveis fendas.

Para a prevenção de novas patologias semelhantes deve-se

- Fazer uma vistoria do material que chega em obra, rejeitando produtos danificados. 
FIGURA 30

Foto: Joan Font.

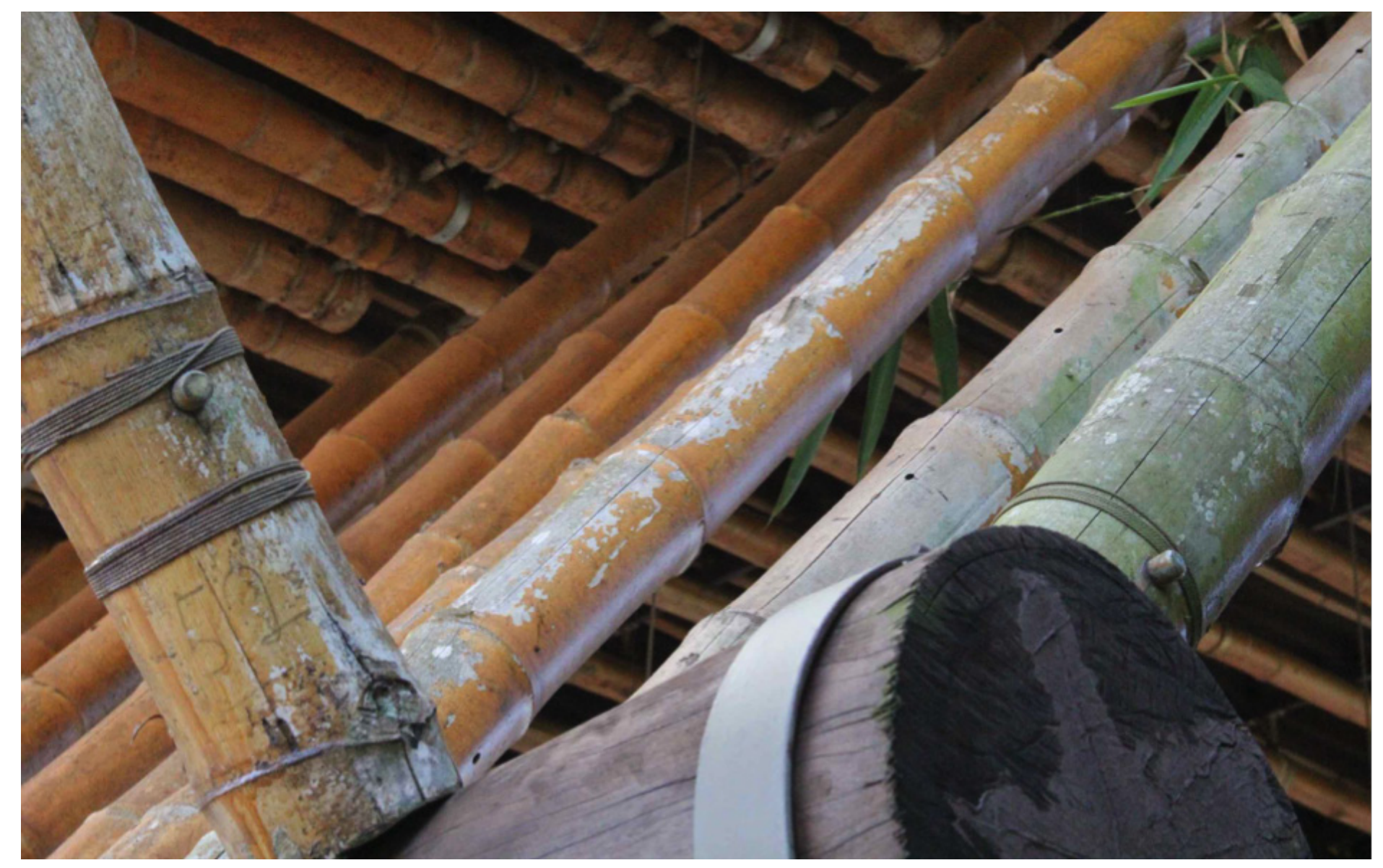




\section{Fungos manchadores por} exposição à água

\section{Descrição por inspeção visual}

Mudança na coloração e na textura

da parte superior dos colmos situados no extremo sudeste do edifício.

Coloração esverdeada (Figura 30).

\section{Causa provável}

Exposição prolongada dos colmos à água da chuva (projeto).

\section{Mecanismo de ocorrência}

Os colmos com essa patologia são os situados nas laterais curtas da cobertura, portanto ficam expostos à chuva. Nessa situação concreta, não há quase exposição ao sol, devido à posição sudeste dos colmos, à pouca incidência solar e pela proteção de vegetação de grande porte nas proximidades. A exposição constante do córtex à chuva permite o depósito de água e de fungos na parte superior, com um ambiente sem excessiva radiação solar que facilita o crescimento e reprodução dos fungos de mofo.

\section{A patologia pode influir no(s)} seguinte(s) fator(es)

- Conforto visual.

Para a correção desta manifestação patológica deve-se

- Polir a superfície e aplicar algum tratamento superficial, como verniz, que evite a consolidação desses microorganismos parasitas. 
FIGURA 31

Foto: Joan Font.

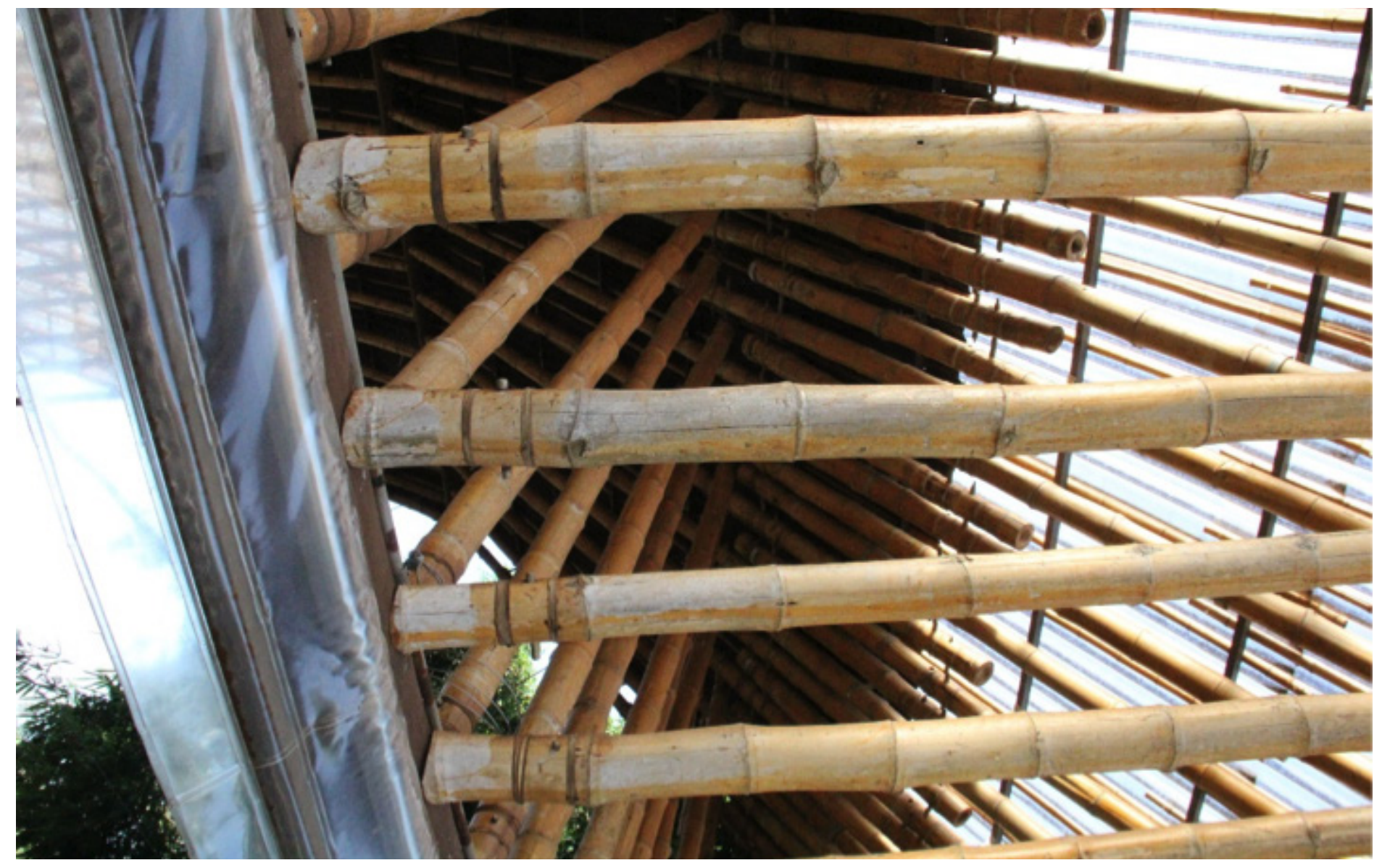




\section{Descrição por inspeção visual}

Coloração distinta ao longo do colmo, identificação de partes com cores não saturadas (Figura 31 ).

\section{Causa provável}

Segundo os registros dos usuários, a última vez que a estrutura de bambu foi pintada foi em 2013. Existe a necessidade prescrita em projeto que a estrutura deve ser pintada em um certo intervalo de tempo (manutenção).

\section{Mecanismo de ocorrência}

O agente responsável pela manutenção a fez há muito tempo, e, com a aplicação do verniz de forma irregular, deixando algumas partes menos protegidas que outras.

A falta de aplicação do verniz com a periodicidade necessária faz com que a camada externa do bambu fique visivelmente exposta a variações de umidade e, consequentemente, a possíveis fendas por dilatações não controladas, com a decorrente falta de estabilidade mecânica.

\section{A patologia pode influir no(s)} seguinte(s) fator(es)

- Durabilidade;

- Estanqueidade (do colmo);

- Conforto visual.

\section{Para a correção dessa manifesta-} ção patológica deve-se

- Aplicação do verniz em todas as superfícies de bambu sem exceção, especialmente aquelas partes com mais exposição à umidade.

Para a prevenção de novas patologias semelhantes deve-se

- Atentar ao manual de uso, operação e manutenção do projeto, e à manutenção prescritiva fornecida pelos projetistas. 
FIGURA 32

Foto: Joan Font.

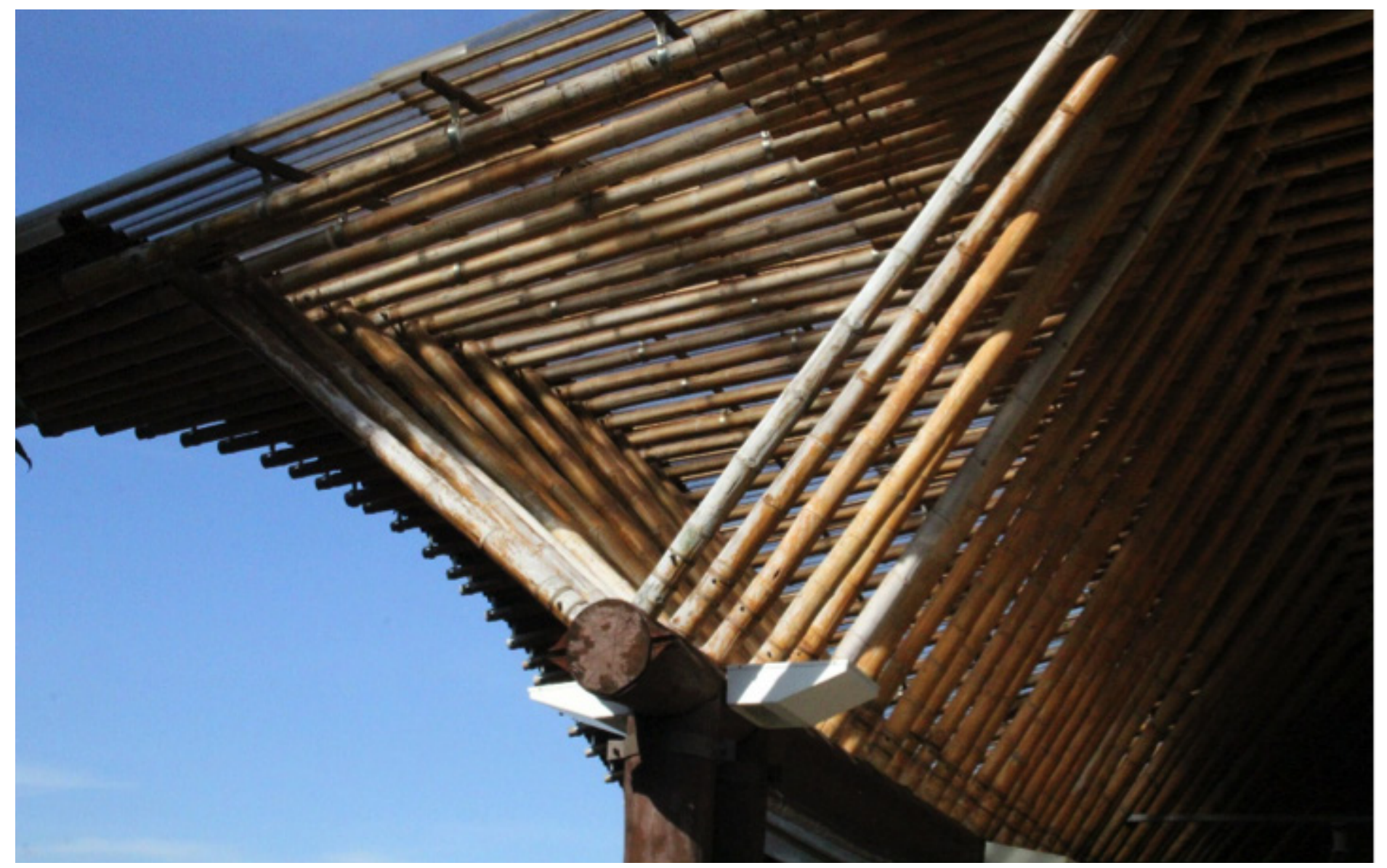




\section{Descrição por inspeção visual:}

Rachaduras nos colmos, desgaste do córtex do bambu, mudança da aparência e da coloração (Figura 32).

\section{Causa provável:}

A concepção do projeto deveria prever a proteção dos bambus e a não exposição direta a fenômenos atmosféricos, como água da chuva e radiações ultravioleta (projeto).

\section{Mecanismo de ocorrência}

As laterais curtas da cobertura ficam expostas às intempéries produzindo dilatações e contrações em intervalos de tempo curtos, originando tensões internas no material e se manifestando em fendas e fissuras. Também a exposição às intempéries produz uma deterioração do córtex, o que tornará o colmo muito mais vulnerável a ataques de agente biológicos.

A origem dessa patologia está no projeto. As longas laterais compridas da cobertura estão bem protegidas pelas telhas, no caso mais desfavorável tem 3,8 m de beiral por uma altura de bambu de $2 \mathrm{~m}$ aproximadamente. No caso das laterais curtas, ao optar por mostrar o corte da estrutura diretamente, não sproteção adequada; com uma altura de 2,5 m não há mais do que $20 \mathrm{~cm}$ de telha protegendo a estrutura.

\section{A patologia pode influir no(s)}

seguinte(s) fator(es)

- Segurança estrutural;

- Durabilidade;

- Estanqueidade do colmo;

- Conforto visual.

\section{Para a prevenção de novas pato-}

\section{logias semelhantes deve-se}

- Projetar qualquer estrutura de bambu com colmos aparentes de forma a não estar exposta sob qualquer circunstância às intempéries

- Prever beirais 1,5 vez a altura do bambu que estará expost.
Para a correção dessa manifestação patológica deve-se

- Trocar os colmos danificados por colmos novos.

- Instalar algum mecanismo de proteção lateral da cobertura, pode ser por meio de telhas, toldo ou outro elemento que se adapte à linguagem arquitetônica do edifício. 
FIGURA 33

Foto: Joan Font.

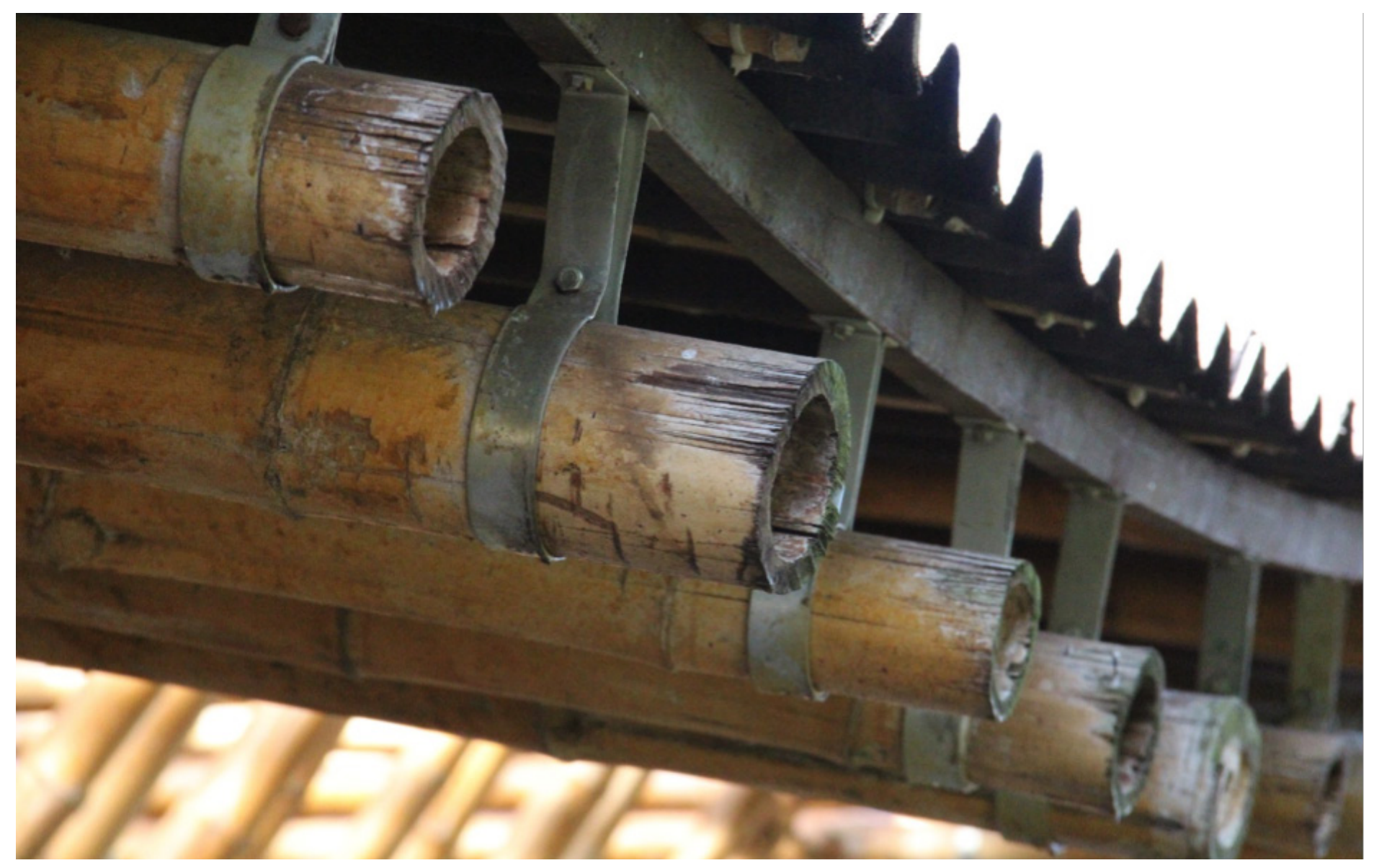




\section{Seção exposta do bambu}

\section{Descrição por inspeção visual}

Deterioração e podridão parda nas seções extremas dos colmos das laterais da cobertura (Figura 33).

\section{Causa provável}

Exposição às intempéries dessas regiões do colmo (projeto).

\section{Mecanismo de ocorrência:}

As extremidades dos colmos ficam fora da área de projeção das telhas, o que facilita a exposição dessas regiões às intempéries, e a mudanças térmicas bruscas provocadas pela exposição direta ao sol.

As variações dimensionais muito bruscas provocadas pelo ganho de teor de umidade ou pelo aumento de temperatura criam tensões no parênquima que não são capazes de resistir, originando fendas ou desagregando os feixes vasculares e desfibrando as partes do córtex mais expostas. A exposição constante à água facilita a aparição de fungos de podridão parda.
Os extremos não estão submetidos a esforços da estrutura, portanto não existe risco de desestabilização estrutural.

\section{A patologia pode influir no(s) seguinte(s) fator(es) \\ - Durabilidade; \\ - Estanqueidade (do colmo); \\ - Conforto visual.}

Para a correção desta manifestação patológica deve-se

- Proteger mecanicamente a extremidade do colmo com alguma luva plástica , tarugos de madeira ou algum elemento que o cubra e evite o contato com a água e a radiação.

Para a prevenção de novas patologias semelhantes deve-se

- Projetar qualquer estrutura de bambu com colmos aparentes de forma a não estar exposta sob qualquer circunstância às intem- péries;

- Prever em projeto que a projeção das telhas em planta siga além da projeção dos colmos. 
- Apesar das patologias encontradas na construção, pode-se concluir que as ações de projeto realizadas, demonstram um domínio muito grande do material e de seu comportamento mecânico.

- Utilizar conexões que permitam o giro dos colmos e não transmitam o momento fletor, geram uma maior estabilidade estrutural dos colmos reduzindo o risco de fendilhamento.

- O comportamento de conexões metálicas tipos 3 e 4 não foi o esperado teoricamente. Existe certa rigidez na conexão que transmite momento fletor no colmo, que em alguns casos o faz colapsar.

- A leveza das estruturas de cobertura de bambu sem vedações laterais permite que a força de sucção do vento faça trabalhar o sistema inteiro no sentido oposto ao que exercem normalmente as forças gravitacionais.

- O projeto deveria ter previsto a proteção dos colmos situados nas laterais da cobertura. Essa omissão permitiu a degradação da maioria de colmos destas regiões pela sua exposição às intempéries.
- O sistema construtivo que permite a substituição dos colmos prevendo a sua baixa durabilidade, deve ser uma premissa para qualquer novo projeto.

- A redundância estrutural é necessária para poder fazer a manutenção e a troca de colmos sem necessidade de escoras e outros sistemas que dificultem e aumentem o custo da operação.

- Pode se comprovar uma clara evolução e maturação dos projetistas em relação à obra da Amana Key. Foram aprimoradas ações de projeto visando à melhora do desempenho construtivo revendo e corrigindo no novo projeto as falhas da estabilidade e da durabilidade. 


\section{Conclusão}

Tendo em vista os aspectos observados ao longo do trabalho, pode-se elencar algumas afirmações conclusivas que permitem, aos profissionais de arquitetura que se proponham a utilizar o em seus projetos, ampliar o campo de conhecimento acerca da utilização do bambu como elemento estrutural em sua condição natural e, aos pesquisadores, nortear futuras investigações que tenham o desempenho construtivo com este material em foco.

Sendo assim, para atingir bons níveis de qualidade construtiva, com índices de desempenho admissíveis, as estruturas de bambu devem atender uma série de requisitos, dentre os quais destaca-se estabilidade estrutural e durabilidade.

A estabilidade de uma estrutura de bambu é garantida pelo bom desempenho mecânico dos elementos que a compõem e pelos princípios arquitetônicos que os ordenam. Portanto, para se garantir a estabilidade do sistema, é necessário garantir também a estabilidade de cada um de seus componentes. Tais componentes dividem-se em duas categorias: barras e conexões.

Uma barra é um segmento extraído a partir de um colmo de bambu, devendo possuir resistência mecânica adequada para a função estrutural a ser desempenhada. A estabilidade dos colmos é garantida por meio de um controle adequado do manejo, realizado de modo a permitir que a planta cresça atingindo todo seu potencial em termos de resistência mecânica, com o mínimo de defeitos anatômicos e a máxima regularidade geométrica.

Também é de suma importância que, na concepção do projeto, que as barras sejam submetidas somente aos esforços aos quais melhor responde. O bambu é um compósito natural cuja constituição microscópica dos tecidos é formada majoritariamente por fibras de celulose, que lhe dão resistência mecânica, e por células de parênquima, que aglomeram as 
fibras e dão corpo e coesão ao material. As fibras estão todas orientadas paralelas ao eixo logitudinal do colmo, com exceção da região dos nós. A composição dos tecidos determina todas as reações do material sob qualquer influência.

Assim, é recomendável solicitar apenas esforços de tração e compressão no eixo longitudinal do colmo, podendo-se ainda, em casos específicos, solicitar esforços de flexão e de cisalhamento perpendicular às fibras. Consequentemente, é altamente desaconselhável solicitar esforços de tração ou compressão perpendiculares às fibras ou solicitar a esforços de cisalhamento interlaminar.

As conexões são elementos de transição que vinculam mecanicamente as barras e transmitem os esforços, distribuindo-os ao longo do sistema. A sua estabilidade depende essencialmente da resistência mecânica do material em si.

É um bom princípio de projeto conceber estruturas onde os colmos não transmitam momentos fletores, utilizando conexões que permitam o giro, como foi visto no exemplo das conexões do Centro Cultural Max Feffer.

A escolha de uma conexão apropriada depende de três fatores:

- A direção dos colmos que une;

- O sistema de transmissão de esforços;

- O grau de complexidade tecnológica na execução que o contexto oferece.

Assim, para conseguir a estabilidade do sistema estrutural, deve-se vincular as barras utilizando-se conexões que transmitam as forças ao longo do sistema de acordo com a forma prescrita, absorvendo as tensões residuais que poderiam comprometer a estabilidade do colmo.

A escolha do tipo de conexão também é influenciada pela estaticidade tomada como partido de projeto que define o sistema estrutural, que pode ser de dois tipos, hiperestático e isostático.

Apesar de o bambu ser definido como material funcionalmente graduado, que em condições naturais resiste muito bem à flexão devido à carga horizontal do vento, e compressão axial devido ao peso próprio, quando totalizam-se mais do que seis restrições em seus extremos podem surgir tensões residuais capazes de causar seu colapso.

Para sistemas estruturais flexíveis, a melhor alternativa é utilizar-se conexões secas, evitando o concreto, pois as diferentes dilatações e comportamentos elásticos dos materiais podem diminuir o desempenho e comprometer a estabilidade dos colmos.

Já a durabilidade de uma estrutura de bambu é estabelecida pela vida útil de projeto e pelos princípios arquitetônicos que ordenam seus elementos, assim como garantida e efetivada pela conservação de seus componentes. É necessário, portanto, garantir a 
durabilidade de cada um de seus elementos, protegendo-os de agentes bióticos e abióticos.

A durabilidade dos colmos é garantida pelo processamento do bambu após a colheitas sendo necessário realizar uma correta secagem e um tratamento preservativo adequado às condições do entorno, prevenindose o ataque de agentes biológicos que possam prejudicar sua estrutura física.

Para obter-se durabilidade satisfatória do sistema, deve-se também proteger os colmos de agentes abióticos, como a água atmosférica e a umidade do solo. As ações de projeto mais comuns para atender este exigência incluem a utilização de beirais e apoio das estruturas por meio de sapatas elevadas. Já a durabilidade das conexões depende da vida útil do material com o qual é feita, devendose prevenir desgastes e proteger as peças quando necessário.

As patologias apresentadas pelo contudo, quando afetam a estabilidade estrutural se manifestam através da aparição de fendas na direção axial na superfície dos colmos. Já as patologias que afetam a durabilidade geralmente se manifestam por mudanças na coloração e textura do colmo, ou por perfurações das paredes.

Os projetos com colmos de bambu estrutural devem levar em consideração a curta vida útil do material e, portanto, devem ser pensados sistemas que permitam substituição de peças e manutenção preventiva, sem que seja necessário despender grandes esforços de infraestrutura para realizar estas operações. Dessa maneira, é importante que as estruturas sejam redundantes e estejam superdimensionadas.

A redundância estrutural e a facilidade de manutenção são princípios de projeto que os arquitetos deveriam assumir para construções futuras com bambu. Os dois exemplos analisados nos estudos de caso dão fé desta brilhante ação de projeto.

A geometria circular do colmo e sua irregularidade limita as possibilidades de agrupamento e de interligação com outros sistemas construtivos, que em geral são dotados de formas retas, e, por serem produzidos industrialmente, apresentam precisão nas formas e facilidade de execução.

Como outras matérias primas, o bambu pode ser processado industrialmente, através de processos como laminação e prensagem. Embora sejam opções que ganham espaços para diversas aplicações, como pisos e demais revestimentos decorativos, em sua forma natural, roliço, é consideravelmente mais barato. Embora haja limitações, com criatividade é possível evita-las e ainda há espaço para explorar suas virtudes.

O bambu então é um material com muitos contrastes, é resistente mas é fraco, é estável mas não é durável. Estas contradições nas suas 
propriedades geram dúvidas a aqueles dispostos a arriscar na sua utilização em estruturas. Precisa ainda muita pesquisa para conseguir que se entre no grupo dos materiais de uso habitual para estruturas.

A sugestão para pesquisas futuras surge a partir das limitações apresentadas pelo bambu, encontradas durante o estudo, e da vontade pessoal de ver os estudos nos seguintes campos aprofundados:

- Métodos de processamento de colmos que permita a formação de elementos estruturais geometricamente customizáveis;

- Análise da vida útil do bambu em diferentes situações ambientais;

- Sistemas construtivos que aproveitem o uso do bambu para tração axial;

- Padronização de uma metodologia de avaliação de estruturas de bambu. 
ABD LATIF M, ASHAARI A, JAMALUDIN K \& MOHD Zin J. Effects of anatomical characteristics on the physical and mechanical properties on Bambusa blumeana. Journal of Tropical Forest Science 6. 1993. p 159-170.

ARCE, O.A. Fundamentals of the design of bamboos structures Eindhoven: Technische Universiteit. Eindhoven, 1993.

ARDILA P., C. L. Determinación de los valores de esfuerzos admisibles del bambú Guadua angustifolia Kunth del departamento de Tolima, Colombia. Dissertação de mestrado apresentada à Facultad de Artes. 93 p. Proyecto Arquitectónico y de Producto da Universidad Nacional de Colombia. Colombia. 2013.

Associação Brasileira de Normas Técnicas (ABNT). NBR 15575: Desempenho de Edifícios Habitacionais. 2013.

NBR 5462: Confiabilidade e mantenabilidade. 1994.

BAMBOO PHYLOGENY GROUP. An updated tribal and subtribal classification of the bamboos (Poaceae: Bambusoideae). In: Proceedings of the $9^{\text {th }}$ World Bamboo Congress, eds. J. Gielis and P. Geert. World Bamboo 
BARBOSA, B. A.; PANDOLI, O tratamento de bambu utilizando de nanopartículas de prata. Departamento de Engenharia Civil. PUCRio. Arquivo Digital. Sem data. Disponível em http://www.puc-rio.br/ pibic/relatorio_resumo2016/relatorios_pdf/ctc/QUI/QUI-Bernardo\%20 Abraham\%20Barbosa.pdf Acesso em: 20 de dezembro de 2016.

BARBOSA, N.P.; GHAVAMI, K.; MOREIRA, L.E. Projeto de Estruturas de Bambu- Procedimento. Arquivo Digital. Sem data. <http://redebrasil12. dominiotemporario.com/doc/Projeto\%20de\%20Estruturas\%20de\%20Bambu. docx> Acesso em: 3 de novembro de 2016.

BERNDSEN, R. S.; KLITZKE, R. J.; BATISTA, D. C.; NASCIMENTO, E. M.; OSTAPIV, F. Resistência à flexão estática e à compressão paralela do bambu mossô (Phyllostachys pubescens). Floresta, Curitiba, v. 43, n. 3. 2013. p. 485 - 494.

Mechanical resistance of moso bamboo (Phyllostachys pubescens) part 2: axial tensile strength, hardness and wear resistance. Floresta, Curitiba, v. 44, n. 3. 2014. p. 505 - 514.

BILESKY, P.R. Caraterização química, física e anatômica do bambu Guadua Tagoara para polpação Kraft. 57 p. Dissertação apresentada à Faculdade de Engenharia do Campus de Guaratinguetá, Universidade Estadual Paulista, Guaratinguetá. 2014.

BRITO, L. D. Patologia em estruturas de madeira: metodologia de inspeção e técnicas de reabilitação. Tese de doutorado apresentada no Departamento de Engenharia de Estruturas da Escola de Engenharia de São Carlos da Universidade de São Paulo. São Carlos. 2014 http://www.set.eesc.usp.br/static/media/ producao/2014DO_LeandroDussarratBrito.pdf Acesso em: 20 de dezembro de 2016

CRUZ, M.L.S. Caraterização física e mecânica de colmos inteiros do bambu da espécie Phyllostachys aurea: comportamento a flambagem. 114 p. Dissertação (Mestrado) Departamento de Engenharia Civil do Centro Técnico Científico da Pontificia Universidade Católica do Rio de Janeiro. 2002 
CULZONI, R. A M. Características dos bambus e sua utilização como material alternativo no concreto. 215 p. Dissertação de Mestrado. Departamento de Engenharia Civil. PUC-Rio. Rio de Janeiro. 1986.

DAS M., BHATTACHARYA S., SINGH P., FILGUEIRAS TS., PAL A. Bamboo taxonomy and diversity in the Era of molecular markers. Adv. Bot. Res. 47. 2008. p.225-268

DRANSFIELD, S. e WIDJAJA, E. A. Plant Resources of Southeast Asia PROSEA no: 7-Bamboos. Backhuys Publishers, Leiden, Holland. 1995

DUNKELBERG, $\mathrm{K}$ et al. Bamboo as building material. Institute for Lightweight structures (IL) Karl Kromer Verlag Stuttgart. University of Stuttgart. 1996

EDWARDS, B. Guía Básica de la Sostenibilidad. Barcelona: Gustavo Gili. 2005.

ENGEL, H. Sistemas estruturais. Editorial Gustavo Gili, SA, Barcelona. 2001.

FERREIRA, E. J. L. O Bambu é um desafio para a conservação e o manejo de florestas no sudoeste da Amazônia. Ciência e Cultura, Set. 2014, vol.66, no.3. 2014. p.46-51

FILGUEIRAS, T. S. e GONÇAVES, A. P. S. A checklist of the basal grasses and bamboos in Brazil. Bamboo Science and Culture 18(1). 2004. p. 7-18.

FREY, P.Learning from Vernacular: Pour une nouvelle architecture vernaculaire, Arles: Actes Sud, 2010.

.; VON SCHAEWEN, D. Simón Vélez Architect / Mastering Bamboo. Arles; Actes Sud. 2013.

GHAVAMI, K.; MARINHO, A. B. Determinação das Propriedades dos Bambus das Espécies: Mosó, Matake, Guadua angustifolia, Guadua tagoara e Dendrocalamus giganteus para Utilização na Engenharia. PUCRio. Publicação RMNC Bambu 01/2001, Rio de Janeiro. 2001. 
Propriedades Mecânicas dos Colmos dos Bambus das Espécies: Mosó e Guadua angustifolia para Utilização na Engenharia. PUCRio. Publicação RMNC-2 Bambu 02/2002, Rio de Janeiro. 2002.

Propriedades Geométricas e Mecânicas de colmos dos bambus para aplicação em construções. Eng. Agríc., Jaboticabal, v.23, n.3, set./dez. 2003. p.415-424.

Propriedades Geométricas e Mecânicas do colmo inteiro do bambu da espécie Guadua. Revista Brasileira de Engenharia Agrícola e Ambiental, v.9, n.1. 2005. p.107-114.

GHAVAMI, K; RODRIGUES, C.S.; PACIORNIK, S. Bamboo: functionally graded Composite material. Asian Journal Of Civil Engineering (Building And Housing) vol. 4, p. 1-10. 2005.

INTERNATIONAL NETWORK FOR BAMBOO AND RATTAN - INBAR. Annual report, 2015.

INSTITUTO COLOMBIANO DE NORMAS TÉCNICAS Y CERTIFICACIÓN CONTEC. NTC 5525 Métodos De Ensayo Para Determinar Las Propiedades Físicas Y Mecánicas De La Guadua Angustifolia Kunth, Bogotá. 2004.

NTC 5407. Uniones para estructura contruídas en Guadua Angustifolia Kunth. Bogotá. 2006.

INTERNATIONAL ORGANIZATION FOR STANDARDIZATION - ISO 22157 1: Bamboo - Determination of physical and mechanical properties - Part 1: Requirements. ISO. 2004

JANSSEN, J. J. A. Designing and building with bamboo. In: INTERNATIONAL NETWORK FOR BAMBOO AND RATTAN (INBAR). Technical Report. n. 20. Beijing, China. 2000. 
JANZEN, D. H. Why bamboos wait so long to flower. Annual Review of Ecology and Systematics 7. 1976. p. 347-391.

JAYANETTI, D. L.; FOLLETT, P. R. Bamboo in construction: an introduction. Ed. 15 International Network for Bamboo and Rattan (INBAR). TRADA. Technology Limited, Department for International, Development (DFID), Minnesota. 1998.

KRAVTSOVA D. Estudo experimental de bamboo da espécie "Phyllostachys Pubescens” sob torção e flexão. p.141. Dissertação de Mestrado em Engenharia Civil na área de estruturas. Pontifícia Universidade Católica do Rio de Janeiro. Rio de Janeiro. 2011.

LIESE, W. Bamboos, Biology, Silvics, Properties, Utilization. Schriftenreihe der GTZ, No180, Eschborn Verlag, Eschborn, Alemanha. 1985.

. The anatomy of bamboo culms. In: INTERNATIONAL NETWORK FOR BAMBOO AND RATTAN (INBAR). China. Technical Report 18. China. 1998.

.; MICHAEL KOHL, M., Bamboo - The Plant and its Uses, Springer International, Switzerland. 2015.

LONDOÑO, X. Evaluation of bamboo resource in Latin America. INBAR, Beijing. 2001.

HIDALGO-LÓPEZ, O. Bamboo. The Gift of the Gods. Bogotá: D’vinni Ltda., 2003.

Bambu, su cultivo y aplicaciones en: fabricación de papel, construcción, arquitectura, ingeniería, artesanía. Estudios Técnico Colombianos Ltda, Cali. 1974.

Manual de construcción con bambú. Estudos Técnicos Colombianos. Ed. Universidad Nacional de Colombia, Centro de Investigación de Bambu y Madera. CIBAM. Bogotá. 1974. Disponível em: <http://bambus. rwth-aachen.de/downloads/connections.pdf> Acesso em: 10 de julho de 2012. 
Ministerio de Ambiente, Vivienda y Desarrollo Territorial - República de Colombia - NSR-10 reglamento colombiano de construcción sismo resistente. Colombia. 2012.

Ministerio de Vivienda, Construcción y Saneamiento, Norma Técnica E. 100 Bambú. Lima. 2011 . Disponível em: <http://www.vivienda.gob.pe/dnc/ archivos/normas/DS-011-2012-VIVIENDA.pdf > Acesso em: 21 de maio de 2015.

MINKE. G Manual de construcción com bambu. Editorial Merlin, Bogotá, Colômbia. 2011.

MONTANER. J. M. As formas do século XX. Editorial Gustavo Gili, Barcelona. 2002.

NOIA, P. R. C. Sustentabilidade socioambiental: desenvolvimento de sistemas construtivos em bambu no Vale do Ribeira, SP. p. 211 Dissertação de mestrado apresentada ao curso de pós-graduação da Faculdade de Arquitetura e Urbanismo da Universidade de São Paulo. São Paulo. 2012.

NOGATA, F., TAKAHASHI, H. Intelligent functionally graded material: Bamboo. Composites Engineering, Vol. 5 No7. 1995. p 743-751.

ONU. Informe Brundland. ONU, Nueva York, 1987.

PADOVAN, R. B. O bambu na arquitetura: design de conexões. p.183. Dissertação (Mestrado em Design). Faculdade de Arquitetura, Artes e Comunicação. Universidade Estadual Paulista, UNESP. Bauru, SP, 2010. Disponível em: < http://www.faac.unesp.br/posgraduacao/design/dissertacoes/ pdf/roberval.pdf> Acesso em: 17 de julho de 2012.

PEREIRA, M. A. R. Projeto Bambu: manejo e produção do bambu gigante (Dendrocalamus Giganteus) cultivado na UNESP / Campus de Bauru e determinação de suas características físicas e de resistência mecânica. Relatorio Fapesp (2003/04323-7) 2006. 
RABELLO, Y. C. P. A Concepção Estrutural e a Arquitetura. Zigurate Editora, São Paulo. 2000.

RICHARD, M. J. Assessing the performance of bamboo structural components. Tese apresentada para obtenção de doutorado na Graduate Faculty of The Swanson School of Engineering da University of Pittsburgh. 2013.

RUGGERIO, M. N. O bambu e a construção da arquitetura contemporânea: um olhar às obras no Brasil. Dissertação de mestrado apresentada ao curso de pós-graduação da Faculdade de Arquitetura e Urbanismo da Universidade de São Paulo. São Paulo. 2015.

RUSINQUE, C. A. Determinação experimental da tenacidade do bambu do modo I (KIC) e do modo II (KIIC). Dissertação de Mestrado em Engenharia Civil da Pontifícia Universidade Católica do Rio de Janeiro. Rio de Janeiro, 2009. Disponível em: < http://www.maxwell.vrac.puc-rio.br/16005/16005_1.PDF > Acesso em: 20 de julho de 2015.

SALGADO, A.L. de B. Bambu com sal: Aqui e agora, lá e então. Editora Amaro Comunicação, Campinas. 2014.

SOARES, S.F.B.S. Estruturas em Bambu. Dissertação de Mestrado em Engenharia Civil para a Faculdade de Engenharia do Porto. Porto. 2013.

SODERSTROM, T. R. e ELLIS, R. P. The position of bamboo genera and allies in a system of grass classification. In "Grass Systematics and Evolution" Smithsonian Institution Press, Washington DC \& London. 1987.

STAPELTON, C. M. A. The morphology of woody bamboos. In "The Bamboos”. Academic Press, London. G. P. Chapman. 1997. p. 251-267. 
TAKEUCHI, C. Comportamiento estructural de la Guadua Angustifolia. Uniones en Guadua. Revista Ingeniería e Investigación, set, año/vol.24 numero 002 Universidad Nacional de Colombia, Bogotá. 2004. Disponível em: < http:// www.redalyc.org/articulo.oa?id=64324201> Acesso em: 17 de abril de 2015.

THOMAZ, E. Trincas em edifício: Causas, prevenção e recuperação. $1^{\text {a }}$ ed. Pini, São Paulo. 1989. Disponível em: <http://www.ebah.com.br/content/ ABAAAgjRsAK/trincas-edificios-causas-prevencao-recuperacao-eng-erciothomaz> Acesso em: 20 de dezembro de 2016.

VAESSEN, M. J.; JANSSEN, J. Analysis of the critical length of culms of bamboo in four point bending tests. Heron, 42(2). 1997. p. 113-124.

VÉLEZ, S.; DETHIER, J.; STEFFENS, K. Grow your own house: Simón Vélez and Bamboo Architecture. Weil am Rhein, Vitra Design Museum. Alemanha. 2000.

VILLEGAS, M. New Bamboo Architecture and Design. Villegas Editores, Bogotá. 2003.

YANG, Y.; HUI, C. China's bamboo. International Network for Bamboo and Rattan (INBAR) Technical Report 33. China. 2010. 


\section{Créditos das figuras}

Capa - Colmos de bambu. Disponível em < https://flic.kr/p/R4Spc> Acesso em março de 2017.

Capítulo 1. Pág. 18-19 - Floresta de bambu em Kawawa-cho, Yokohama, Japão. Disponível em < https://pxhere.com/fi/photo/266831 > Acesso em março de 2017.

Capítulo 2. Pág. 38-39 - Colmos de bambu. Disponível em < https://flic.kr/p/R4Spc> Acesso em março de 2017.

Capítulo 3. Pág. 66-67 - Seções de bambu estocado. Disponível em < https://flic.kr/p/8ik9r6> Acesso em março de 2017.

Capítulo 4. Pág. 88-89 Celeiro de tabaco em Tutul, Balung, Jember de Java Leste. Disponível em < https://flic.kr/p/5tfVz4> Acesso em março de 2017.

Capítulo 5. Pág. 118-119 Sala de diálogos de verão Amana Key, Cotia, Brasil AUTOR: Joan Font. 